Aus dem Department für Nutzpflanzenwissenschaften, Abteilung Pflanzenvirologie der Georg-August-Universität Göttingen

Untersuchungen zur Interaktion des Pathogenitätsfaktors P25 des beet necrotic yellow vein virus mit Proteinen der Zuckerrübe (Beta vulgaris L.)

\author{
Dissertation \\ zur Erlangung des Doktorgrades \\ der Fakultät für Agrarwissenschaften \\ der Georg-August-Universität Göttingen
}

vorgelegt von

Heike Thiel

geboren in Gehrden

Göttingen, Dezember 2008 
D 7
1. Referent: Prof. Dr. Mark Varrelmann
2. Korreferent: Prof. Dr. Heiko Becker
Tag der mündlichen Prüfung: 21.01 .2009 


\section{Inhaltsverzeichnis}

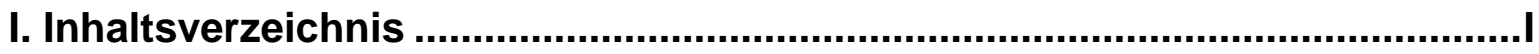

II. Abkürzungsverzeichnis ......................................................................... IV

Kapitel 1: Allgemeine Einleitung ...............................................................1

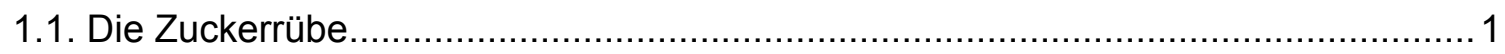

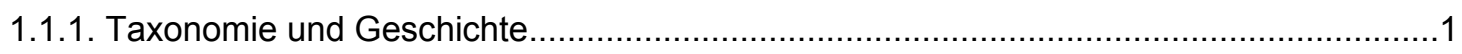

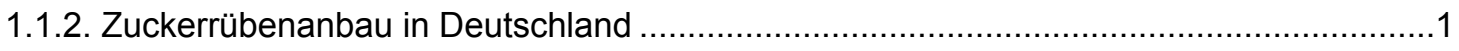

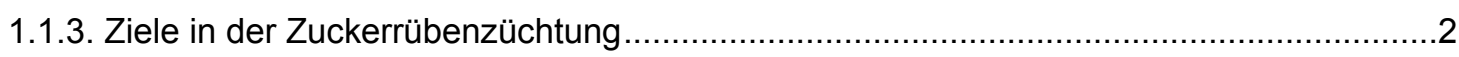

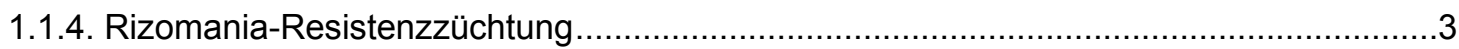

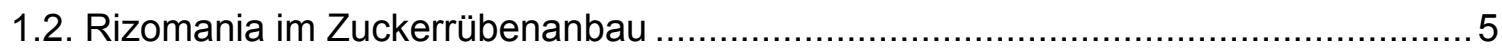

1.2.1. Beet necrotic yellow vein virus und sein Vektor Polymyxa betae ...................................

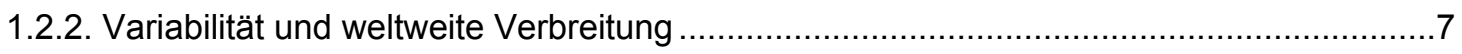

1.2.3. Pathogenitätsfaktor P25 - Einfluss, Tetradenkompositionen und dessen

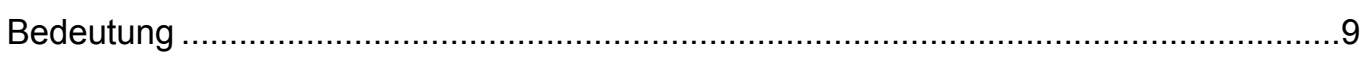

1.3. Methoden zum Nachweis von Protein-Protein Interaktionen .............................. 10

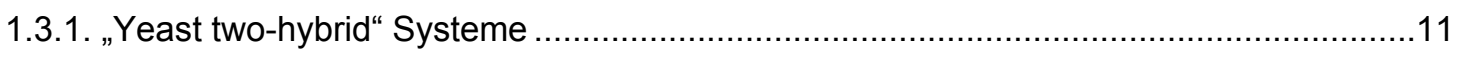

1.3.2. Schwierigkeiten und Adaptionen von Yeast two-hybrid Systemen ................................13

1.3.3. Systeme für die Bestätigung von Protein-Protein Interaktionen ..................................15

1.3.4. Untersuchungen von Protein-Protein Interaktionen zur Charakterisierung von

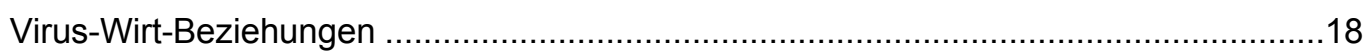

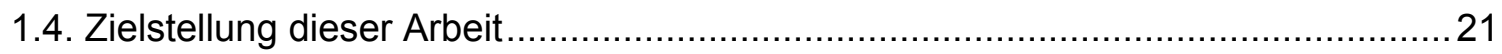

Kapitel 2: Molecular Biology of the Beet necrotic yellow vein virus ..............22

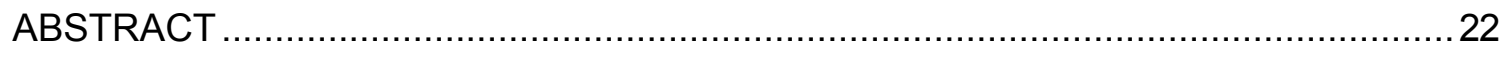

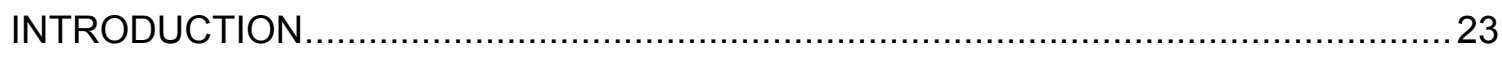

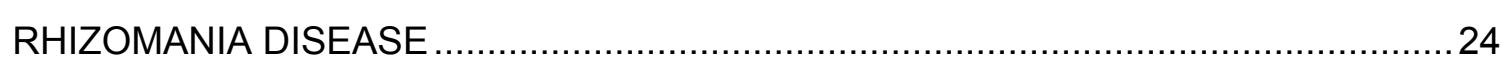

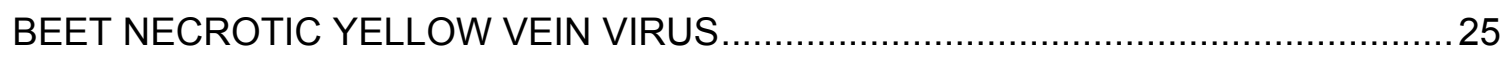

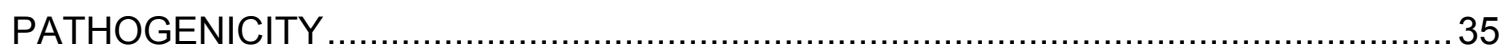

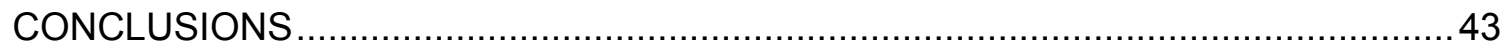

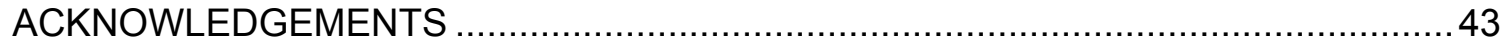

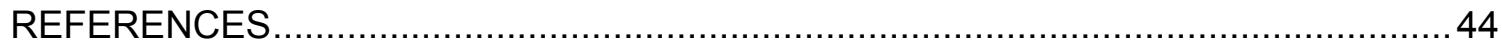

Kapitel 3: Identification of beet necrotic yellow vein virus P25 pathogenicity factor interacting sugar beet proteins which represent putative virus targets or components of plant resistance...........................60 


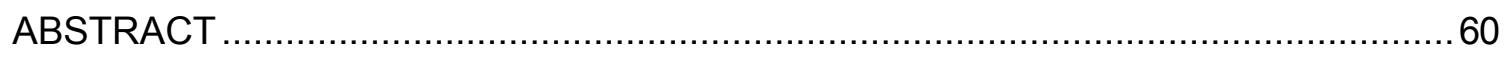

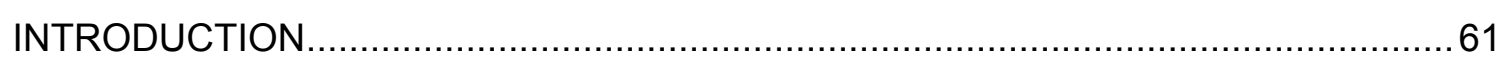

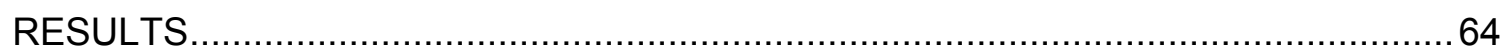

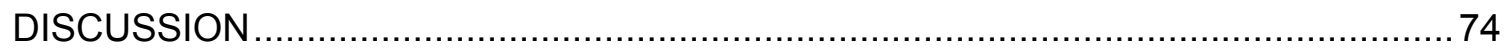

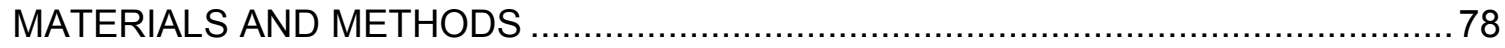

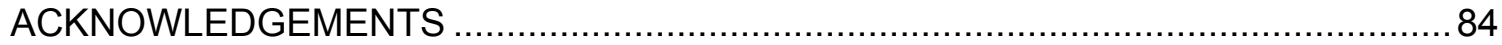

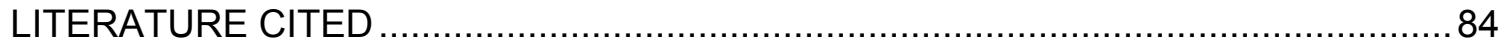

Kapitel 4: Beet necrotic yellow vein virus P25 pathogenicity factor interacts with a sugar beet F-box protein from resistant and susceptible genotypes involved in the induction of a hypersensitive

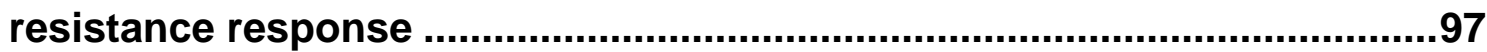

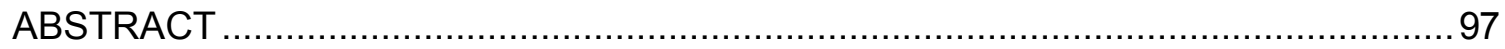

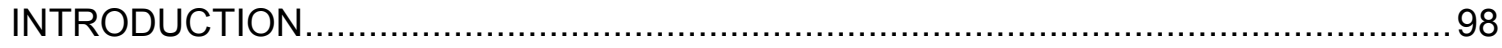

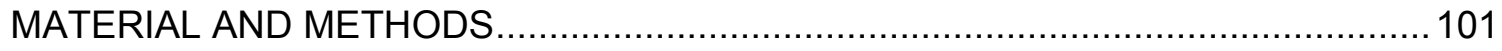

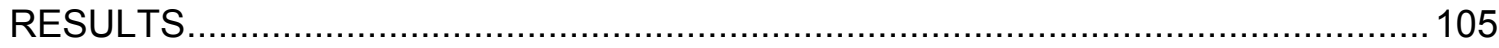

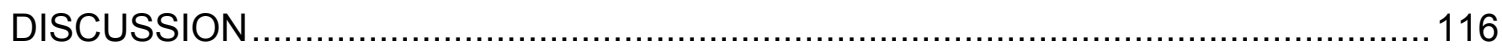

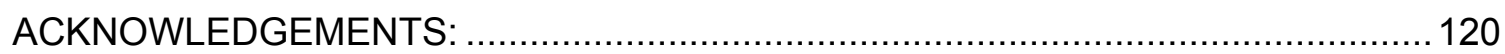

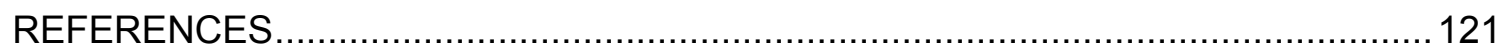

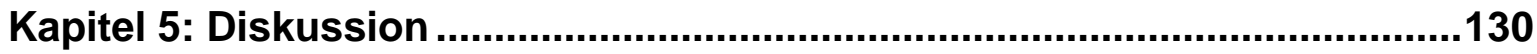

5.1. Beurteilung des Yeast two-hybrid Systems als Screening-Methode zur Identifizierung von Proteininteraktionen ........................................................ 130

5.2. Eignung des "Bimolecular fluorescence complementation assay" zur

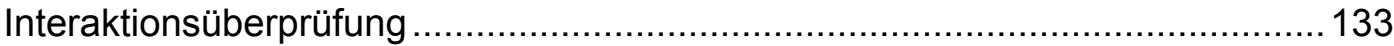

5.3. Screening des zweiten (viralen) Pathogenitätsfaktors P26 des BNYVV ............ 135

5.4. Eine Beteiligung des F-box Kandidaten an der Virusresistenz? ....................... 137

5.5. Möglichkeiten für die weitere Charakterisierung von P25 interagierenden

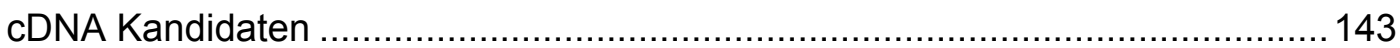

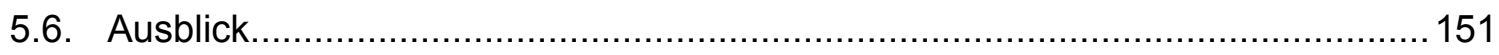

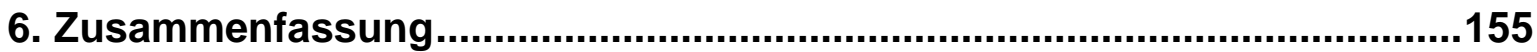

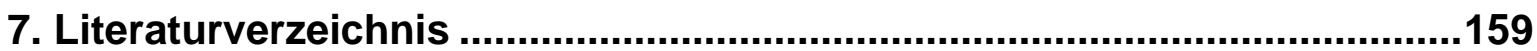

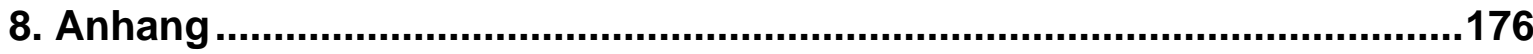

8.1. Construction of a random primed normalized cDNA library from Beta vulgaris.. 176

Danksagung 
Verzeichnis der Publikationen und Tagungsbeiträge ...................................183

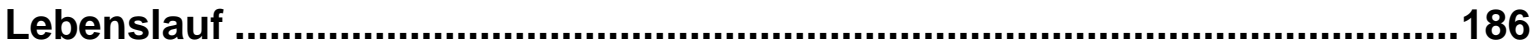




\section{Abkürzungsverzeichnis}

$\%$

Abb.

ACRE

As

AD

ANX

ARM

A. thaliana

A. tumefaciens

Avr

BAC

BD

BiFC

$\mathrm{B} 2 \mathrm{H}$

BCMV

BNYVV

BSBMV

BWYV

bzw.

ca.

CaMV

CM

CMS

Co-IP

C. quinoa

C. papaya

CP
Prozent

Abbildung

„Avr9/Cf-9 rapidly elicited”

Aminosäure

DNA aktivierende Domäne

„Annexin repeats“

„Armadillo/beta-catenin-like repeats“

Arabidopsis thaliana

Agrobacterium tumefaciens

Avirulenzgen

„bacterial artificial chromosome“

DNA bindende Domäne

„bimolecular fluorescence complementation”

„bacterial two-hybrid”

bean common mosaic virus

beet necrotic yellow virus

beet soil-borne mosaic virus

beet western yellows virus

beziehungsweise

circa

cauliflower mosaic virus

Zentimorgan

Cytoplasmatische männliche Sterilität

Co-Immunopräzipitation

Chenopodium quinoa

Carica papaya

„coat protein” (Hüllprotein) 


\begin{tabular}{|c|c|}
\hline d.h. & das heißt \\
\hline ER & extreme Resistenz \\
\hline engl. & englisch \\
\hline Etc. & Etcetera \\
\hline FRET & "fluorescence resonance energy transfer" \\
\hline G. hirsutum & Gossypium hirsutum \\
\hline GFP & „green fluorescent protein“ \\
\hline ggf & gegebenenfalls \\
\hline GST & Glutathion-S-Transferase \\
\hline GUS & $\beta$-Glucuronidase \\
\hline
\end{tabular}

HA Haemagglutinin

HR Hypersensitive Reaktion

IAA "Indole-3-Acetic Acid"

ICTV International Committee on Taxonomy of Viruses

IV Imperial Valley

$\mathrm{Kb} \quad$ Kilobasen

$\mathrm{kDa} \quad$ Kilodalton

LRR

"leucine rich repeat"

LRR-Extensin „leucine rich repeat family/extensin family protein“

$\mathrm{Mb} \quad$ Megabasen

$\mathrm{M} 2 \mathrm{H} \quad$ „mammalian two-hybrid”

Mio. Million

mRFP „monomeric red fluorescent protein“

NBS "nucleotide binding site“

NES "nuclear export signal” 
NLS

$\mathrm{n}$

$\mathrm{nm}$

o.a.

P. betae

PSBMV

$P V X$

PR

QTL

$r$

$R$

RDV

RAPD

RFLP

RGA

RNAi

RNA

SAR

S. cerevisae

SCF

SSCP

ssp.

$\mathrm{t}$

TCV

TIP

TMV

TOC1 „nuclear localization signal”

Anzahl

nanometer

oben aufgeführt

Polymxa betae

pea seed-borne mosaic virus

potato virus $X$

„pathogenesis related“

„quantitative trait loci”

Resistenzgen, rezessiv

Resistenzgen, dominant

rice dwarf virus

„random amplified polymorphic DNA“

"restriction fragment length polymorphism"

„resistance gene analogues“

RNA-Interferenz

Ribonukleinsäure

"systemic acquired resistance"

Saccharomyces cerevisae

SKP1, Cullin1, F-box

"single strand conformation polymorphism"

Subspezies

Tonne

turnip crinkle virus

TCV-interagierendes Protein

tobacco mosaic virus

„timing of cab expression" 
TRV

u.a.

UAS

var.

VPg

$\mathrm{Y} 3 \mathrm{H}$

YFP

YTH

z.B.

ZTL

z.T. tobacco rattle virus

unter anderem

„upstream activating sequence“

Varietät

„Virus proten, genome linked"

„yeast three-hybrid”

„yellow fluorescent protein”

„yeast two-hybrid"

zum Beispiel

Zeitlupe

zum Teil 


\section{Kapitel 1: Allgemeine Einleitung}

\subsection{Die Zuckerrübe}

\subsubsection{Taxonomie und Geschichte}

Die Zuckerrübe ist eine der jüngsten Kulturpflanzen Europas. Die Kulturart Beta vulgaris ssp. vulgaris stammt vermutlich ursprünglich von der Wildform Beta vulgaris ssp. maritima ab (Oltmann et al., 1984). Sie gliedert sich in die Familie der Chenopodiaceae ein und gehört zur Gattung Beta L. Die Gattung unterteilt sich in die vier systematische Sektionen Beta, Corollinae, Nanae und Procumbentes (Ford-Lloyd et al., 1975; Letschert et al., 1994). Aus Sicht der landwirtschaftlichen Nutzung gilt die Sektion Beta aufgrund ihrer verschiedenen Kulturformen als die Bedeutendste. Neben der Zuckerrübe Beta vulgaris ssp. vulgaris var. altissima, gehören auch die Kulturpflanzen Mangold (B. vulgaris cicla), Rote Beete (B. vulgaris conditiva) und Futterrüben (B. vulgaris crassa) zu dieser Gattung.

Ende des siebzehnten Jahrhunderts wurden die mit wichtigsten Erkenntnisse in der Geschichte der ackerbaulichen Zuckerrübennutzung gemacht. Der Physiker Andreas Sigismund Marggraf entdeckte in Roter Beete und Runkelrübe süßschmeckende Kristalle, die in ihrer Zusammensetzung mit denen des Zuckerrohres identisch waren. Der Zuckerertrag dieser Rüben war sehr gering. Franz Carl Achard, ein Schüler Marggrafs, schuf durch phänotypische Selektion Rüben mit höherem Zuckerertrag und es wird vermutet, dass durch die natürliche Kreuzung von Mangold und Futterrübe die zuckerreiche Form, die „Weiße schlesische Rübe" entstand (Draycott, 1991) Die heute verfügbaren Zuckerrübensorten gehen auf diese gezüchtete schlesische Rübe (de Bock, 1986) zurück. Durch diese Grundlagenforschung konnten die heute im Anbau befindlichen, ertragsreichen Zuckerrüben mit einem Zuckergehalt von ca. 16-18 \% gezüchtet werden.

\subsubsection{Zuckerrübenanbau in Deutschland}

Die Zuckerrübe ist eine zweijährige Kulturpflanze, die im ersten Jahr der Anbauperiode nach ausreichender Speicherwurzelbildung geerntet wird. Dabei lagern die Zuckerrüben in den gebildeten Speicherwurzeln Kohlenhydrate in Form von Saccharose ein. 
Die landwirtschaftlich bewirtschaftete Fläche in Deutschland betrug im Jahr 2007 insgesamt 11,9 Mio. ha. Dabei wurden mehr als 50\% des Ackerlandes mit Getreide als größter Anbaugruppe bewirtschaftet. Hackfrüchte stellen nur einen kleinen Teil von knapp $6 \%$ dar, von der der Zuckerrübenanbau 3,3\% ( 390.000 ha Anbaufläche) ausmacht. Die Zuckererzeugung im Zeitraum 2007/2008 erreichte eine Gesamtmenge von 4 Mio.t, was einen 20\%igen Mehrertrag zum Vorjahr bedeutet (Wirtschaftliche Vereinigung Zucker, 2008). In Norddeutschland konnte trotz des Inkrafttretens der europäischen Zuckermarktordnung von 2005 eine Erhöhung der Zuckerrübenanbaufläche von $20 \%$ zum vorherigen Anbaujahr erreicht werden. Weitere Verwendungsmöglichkeiten, wie die Herstellung von Bioethanol und eine mögliche Perspektive zur Erzeugung von Biogas, weisen auf die zukünftige Wettbewerbsfähigkeit der Zuckerrübe hin (Spicher, 2008).

\subsubsection{Ziele in der Zuckerrübenzüchtung}

Zuckerrüben sind selbstinkompatible Fremdbefruchter mit einem haploiden Chromosomensatz von $\mathrm{n}=\mathrm{x}=9$ und einer geschätzten Genomgröße von ca. 714$758 \mathrm{Mb}$ (Kole, 2007). Eines der für die arbeitstechnische Vollmechanisierung wichtigsten Züchtungserfolge war die Entwicklung der Einkeimigkeit (Monogermie) des Zuckerrübensaatguts (Seldmayer, 1964). Ursprünglich bildeten Zuckerrüben sogenannte Knäuel, die aus 4-5 verwachsenen Samen bestehen und nach Aussaat mittels Handarbeit vereinzelt wurden. Der Ploidiegrad der Zuckerrübensorten ist durch den Züchter leicht veränderbar. Die meisten Sorten sind diploid $(2 n=2 x=18)$, aber auch triploide Sorten $(3 n=3 x=27)$ sind erwerbbar (Bosemark, 1993; Beschreibende Sortenliste, 2008). Triploide Sorten werden aus Kreuzungen von diploiden, monogermen Mutter- und tetraploiden Vaterpopulationen gekreuzt (Becker, 1993; Bosemark, 1993). Zu Beginn der Züchtung verschiedener Ploidiegrade erschienen triploide Sorten als beste Möglichkeit zur Erzeugung stabiler Monogermie, die den gewünschten Leistungsund Qualitätsvoraussetzungen entsprachen und den bis dahin vorhandenen multigermen Sorten ebenbürtig waren. Seit dem Ende der 70er Jahre wurden diploide, monogerme Sorten entwickelt, die den triploiden in ihren Fähigkeiten nicht nur gleichwertig waren, sondern in speziellen Bereichen, wie z.B. hohe 
Samenqualität, die sich u.a. in Form von guter Keimfähigkeit wiederspiegelt, überlegen waren (Oltmann et al., 1984). Beim Anbau von Zuckerrüben sind Eigenschaften, wie Ertrags- und Qualitätsverbesserung von großer Bedeutung. Weitere Zuchtziele werden zum einen von den Landwirten, zum anderen von der verarbeitenden Industrie bestimmt. Dabei steht das Interesse der verarbeitenden Industrie vor allem für die technische Qualität in Form von verlustarmer Zuckergewinnung im Vordergrund. Aus landwirtschaftlicher Perspektive ist die Flächenproduktivität ein zentrales Zuchtziel. Um diesen Anforderungen gerecht zu werden, sind in der Züchtung die Steigerung des Rübenertrags und die Erhöhung des Weißzuckergehalts die elementaren Ziele. Bei der Entwicklung von Sorten müssen Korrelationen zwischen bestimmten Eigenschaften berücksichtigt werden. Beispielsweise besteht zwischen den Merkmalen Zuckerertrag und Rübenertrag eine sehr große positive Korrelation. Die Merkmale Zuckergehalt und Rübenertrag hingegen sind negativ korreliert. Schlussfolgernd aus diesen Korrelationen werden unterschiedliche Sortentypen entwickelt, der Ertragsbetonte E-Typ, der Zuckergehaltbetonte Z-Typ, sowie der intermediäre N-Typ, der mit seinem Zuckergehalt und/oder Zuckerertrag zwischen dem E- und dem Z-Typ liegt. (Oltmann et al., 1984; Draycott, 1991; Becker, 1993).

Die Zuckerrübe ist stark selbstinkompatibel. Sämtliche, derzeit kommerziell erwerbbaren Zuckerrübensorten sind aus der Hybridzüchtung hervorgegangen. Durch die Verwendung der Hybridzüchtung ist die Ausnutzung der Heterosis möglich. Allgemein werden in der Hybridzüchtung bei Zuckerrüben eine mütterliche cytoplasmatisch männlich sterile (CMS) Linie, die zusätzlich die Eigenschaft der Monogermität trägt, mit einer pollenfertilen Vaterlinie, die meist multigerm und aufgrund der Mehrblütigkeit eine hohe Pollenmenge besitzt, gekreuzt (Ford-Lloyd et al., 1975; Poehlman, 1986; Bosemark, 1993; Koch, 2006).

\subsubsection{Rizomania-Resistenzzüchtung}

Rizomania bezeichnet eine Krankheit an Zuckerrübe, die durch das beet necrotic yellow vein virus (BNYVV) verursacht und durch den bodenbürtigen Vektor Polymyxa betae übertragen wird. Die Rizomaniaresistenzzüchtung beschäftigt sich mit der Entwicklung von BNYVV toleranten Sorten. Toleranz bedeutet, dass Entwicklung, wie auch pflanzenbaulich-relevante Leistungsmerkmale trotz 
Virusbefall die Zuckerrübe kaum oder nicht negativ beeinflußt werden. D.h. rizomaniatolerante Sorten tolerieren den Befall mit dem Pathogen und erzielen auch auf befallsfreien Flächen ein Ertragsniveau vergleichbar zu nichtbefallenen Sorten (Hoffmann et al., 1994). Die Möglichkeiten der Bekämpfung des virusübertragenden Vektors $P$. betae, der in Ackerböden weit verbreitet ist, durch chemisch, wie auch thermische Bodenhandlungen ist zum einen nicht wirtschaftlich, zum anderen aus ökologischer Sicht nicht tragbar. Auch eine Weiterstellung der Zuckerrübe in der Fruchtfolge lässt aufgrund der Langlebigkeit der P. betae Dauersporen von bis zu 15 Jahren (Abe und Tamada, 1996) keinen deutlichen Erfolg erwarten. Die derzeit erwerbbaren rizomaniatoleranten Zuckerrübensorten basieren auf monogenen Resistenzen und werden im Allgemeinen als rizomaniaresistent bezeichnet. Aus diesem Grund wird im weiteren Verlauf dieser Arbeit ausschließlich der Begriff resistent benutzt. Die in den Zuckerrübensorten verwendeten Majorgene Rz1, Rz2 (Kapitel 2) liegen auf Chromosom 3 des Zuckerrübengenoms in einem Abstand von 20-25cM (Scholten et al., 1999; Amiri et al., 2003). Ein wichtiger Entwicklungsschritt in der Etablierung dieser rizomaniaresistenten Sorten war die Erzielung einer ähnlich hohen Ertragsleistung resistenter Sorten unter Nichtbefallsbedingungen im Vergleich mit anfälligen Sorten.

Rizomaniaresistente Zuckerrübensorten werden als CMS-Hybridsorten erzeugt. Die BNYVV Resistenz ist ein qualitatives Merkmal, das dominant über die bereits genannten Majorgene vererbt und zusätzlich durch Minorgene, deren genaue Vererbung ungeklärt ist, beeinflusst wird (Koch, 2006). In der Rizomaniaresistenzzüchtung stellen die Züchter mittels Handkreuzungen von kastrierten Pflanzen $F_{1}$-Linien her, die anschließend auf Resistenz und Leistung (z.B. Zuckerertrag) geprüft werden. Die Linien mit den besten, gewünschten Eigenschaften werden als Sortenkomponente eingesetzt. Die Rizomaniaresistenz einer Sorte kann sowohl vom Saatelter, der das CMS-Cytoplasma trägt, als auch von den eingesetzten Pollenspenderpflanzen mit fertilem Cytoplasma weitergegeben werden. Bei Sorten mit der Kombinationsresistenz Rz1/Rz2 kann die Rizomaniaresistenz beidseitig von Vater- und Mutterlinie gleichzeitig vererbt werden (persönliche Mitteilung W. Mechelke, KWS Saat AG). Um die BNYVV Resistenzzüchtung zu verbessern, werden seit mehreren Jahren molekulare 
Marker unterstützend hinzugezogen. Die derzeit meist verwendete Selektionsmethode ist die Anwendung von QTL („quantitative trait loci“) und die Möglichkeit der Identifizierung ihrer genomischen Positionen, bekannt als QTL Kartierung (Hui Liu, 1998). Die Zuckerrübenzüchter haben bereits molekulare Marker entwickelt, die eng mit dem Rz1 Gen gekoppelt sind (Barzen et al., 1992). Die markergestützte Selektion wird bei der Rizomaniaresistenzzüchtung subsidiär für die Auswahl von resistenten homozygot aufspaltenden $F_{1}$-Linien eingesetzt (Kraft, 2001).

\subsection{Rizomania im Zuckerrübenanbau}

Rizomania ist eine Viruserkrankung an Zuckerrübe, die sehr große wirtschaftliche Bedeutung hat. Im Zuckerrübenanbau führte sie, nach erstem Auftreten 1959 (Canova, 1959) schnell zu einer ökonomischen Bedrohung, da ein Rizomaniabefall hohe Ertragsverluste (bis 70\% und mehr) (Johansson, 1985; Richard-Molard, 1985) und stark reduzierte Zuckergehalte bedingen kann.

Rizomaniasymptome sind an der gesamten Zuckerrübenpflanze festzustellen, wobei am Blattapparat auftretende Symptome weitaus seltener zu beobachten sind, im Gegensatz zu deutlich ausgeprägten Symptomen am unterirdischen Rübenkörper. Typische Blattsymptome sind nesterweise auftretende Blattaufhellungen in Feldbeständen sowie seltener vorkommende Welkeerscheinungen trotz ausreichender Bodenfeuchte. Das Symptombild, nachdem BNYVV benannt wurde, ist eine deutliche Blattadernaufhellung am Rübenblatt. Am Rübenkörper kommt es zur Ausbildung eines Wurzelbartes, der anstelle einer Pfahlwurzel viele Seitenwurzeln ausbildet. Des Weiteren können Einschnürungen der Pfahlwurzel und Verbräunungen der Gefäßleitbündel als Symptom beobachtet werden (Tamada und Baba, 1973; Johansson, 1985; Asher, 1993).

Rizomania, auch bekannt als die „viröse Wurzelbärtigkeit", wird durch das beet necrotic yellow vein virus verursacht (Tamada und Baba, 1973) (Kapitel 2). Der Überträger des BNYVV, auch Aderngelbfleckigkeitsvirus genannt, ist der bodenbürtige Plasmodiophoromycet Polymyxa betae Keskin (Keskin, 1964). Seit der erstmaligen Erwähnung der Krankheit in den fünfziger Jahren (Canova, 1959) 
ist das Virus in den wichtigsten Zuckerrübenanbaugebieten Europas sowie auch weltweit, z.B. in Asien und den USA, aufgetreten (Asher, 1993; Tamada, 1999; Lennefors et al., 2000; Nielsen et al., 2001). Untersuchungen von ca. 1,6 Mio. ha europäischer Zuckerrübenanbaufläche ergaben einen kontinuierlichen Anstieg der Befallsfläche von 15\% im Jahr 1990 auf 38\% im Jahr 2006 (Varrelmann, 2007). Schätzungen gehen davon aus, dass die befallene landwirtschaftliche Zuckerrübenanbaufläche bis zum Jahr 2010 auf 56\% ansteigt (Johansson, 1985; Richard-Molard und Cariolle, 2001). Ertragseinbußen bis zu 70\% können durch Rizomaniabefall hervorgerufen werden (Johansson, 1985; Richard-Molard und Cariolle, 2001). Der Zuckergehalt kann in befallenen Speicherwurzeln der Zuckerrüben von den erzielbaren $16-18 \%$ auf bis zu $7 \%$ reduziert sein (Bongiovanni und Lanzoni, 1964). Die in den letzten Jahren beobachtete schnelle Ausbreitung der Krankheit ist vor allem auf die derzeit verfügbaren BNYVV resistenten Sorten zurückzuführen. Diese sind gegenüber dem Virus nicht unangreifbar. Bei den in den Sorten vorliegenden Resistenzen handelt es sich um Ausbreitungsresistenzen, nicht um Infektionsresistenzen, d.h. die Infektion der Pflanze durch das Virus wird nicht unterbunden, sondern lediglich die Ausbreitung innerhalb der Pflanze verhindert. Daraus folgt, dass sich die Virusgehalte sowie die beladenen $P$. betae Vektoreinheiten im Boden nicht zwingend verringern (Varrelmann, 2007). Des Weiteren muss auch der Vektor P. betae für die Verbreitung mit berücksichtigt werden. Der Wirtskreis beschränkt sich auf die Familien der Chenopodiaceae, Amaranthaceae, Caryophyllaceae und Portulacaceae (Rush, 2003; Mouhanna et al., 2008).

Die Virusverbreitung geschieht über vielfältige, schwer kontrollierbare Möglichkeiten. Infizierte Bodenpartikel können mittels Wasser (Beregnung, Grundwasser, etc.), durch Wind, Tiere oder Resterde in landwirtschaftlichen Maschinen verbreitet werden. Deshalb ist ein qualitativ und quantitativ rentabler Zuckerrübenanbau nur durch die Kultivierung von derzeit verfügbaren rizomaniaresistenten Sorten möglich. 


\subsubsection{Beet necrotic yellow vein virus und sein Vektor Polymyxa betae}

Beet necrotic yellow vein virus wurde 1997 durch das "International Commitee on Taxonomy of Viruses (ICTV)“ als Typspezies dem Genus Benyvirus zugeordnet (Hull, 2002). Neben BNYVV gehört das Beet soil-borne mosaic virus (BSBMV) ebenfalls zum Genus Benyvirus (Tamada, 1999; Lee et al., 2001; Rush, 2003). Die, dem Genus zugehörigen Viren BNYVV und BSBMV werden durch den Protisten P. betae Keskin (Keskin, 1964) im Boden übertragen und zeigen eine sehr enge Verwandtschaft aufgrund hoher Nukleotidhomologien der viralen Genome (Lee et al., 2001).

Das Genom des Virus besteht in Abhängigkeit vom Isolat aus vier- bzw. fünf stäbchenförmigen Partikeln (Kapitel 2, Abb. 3), die einzelsträngige RNA in Plusstrang-Orientierung tragen. Mittels elektronenmikroskopischer Aufnahmen können die verschiedenen Längen der BNYVV Partikel sichtbar gemacht werden (Kapitel 2, Abb. 2). Der Durchmesser der verschiedenen RNAs beträgt 30nm. Die Länge kann dabei zwischen 65 bis 390nm variieren (Putz, 1977). In Feldisolaten werden meist vier (bei besonderen BNYVV Typen bis zu fünf) verschiedene Viruspartikel nachgewiesen. Untersuchungen haben gezeigt, dass die auf RNA3, 4 und 5 kodierten Funktionen nur für die natürliche Infektion notwendig sind. „Housekeeping“ Funktionen, wie Replikation, Zell zu Zell Ausbreitung, Enkapsidierung und „supressor of gene silencing“ sind bereits auf RNA1 und RNA2 kodiert (Tamada, 1999; Dunoyer et al., 2002). Folglich sind RNA1 und RNA2 für die BNYVV Infektion und Replikation und sowie für die künstliche Inokulation von Lokalläsionwirten z.B. Chenopodium quinoa ausreichend. Genomorganisation und Funktionen der unterschiedlichen RNA-Fragmente sind in Kaptitel 2 dargestellt und ausführlich beschrieben.

\subsubsection{Variabilität und weltweite Verbreitung}

Der Erreger der Rizomania, BNYVV, wird in Europa in drei verschiedene Gruppen differenziert, die als A-, B- und P-Pathotyp bezeichnet werden. Die Identifikation fand durch die Anwendung von molekularen Analysen, wie der Detektion von „restriction fragment length polymorphism“ (RFLP) und „single-stranded 
conformation polymorphism" (SSCP) in der Gensequenz des BNYVV Hüllproteins, statt (Kruse et al., 1994; Koenig et al., 1995).

Der B-Pathotyp ist in Deutschland der am häufigsten auftretende, kommt aber auch in Frankreich, Schweden, China und Japan vor. Dem gegenüber besitzt der A-Pathotyp in den meisten europäischen Ländern, sowie dem Iran, Nordamerika, China und Japan seine Verbreitung (Saito et al., 1996; Miyanishi et al., 1999; Lennefors et al., 2000; Sohi und Maleki, 2004). Die beiden BNYVV Pathotypen A und $B$ können in Abhängigkeit von der untersuchten viralen RNA ca. 3-6\% Sequenzunterschied auf Nukleinsäureebene aufweisen. Die Unterschiede zwischen BNYVV Typen wurden mit Hilfe molekularer Diversitätsstudien und damit verbundenen phylogenetischen Analysen beschrieben (Schirmer et al., 2005). Innerhalb dieser beiden Pathotypen sind die Sequenzen äußerst stabil, hoch konserviert und zeigen eine Sequenzidentität von 99\% (Koenig und Lennefors, 2000). Im Gegensatz zu den Pathotypen A und B, die vier RNA Segmente besitzen, unterscheidet sich der dritte BNYVV Pathotyp P durch eine zusätzliche RNA5 deutlich gegenüber den zwei zuvor genannten Pathotypen (Koenig et al., 1997; Koenig und Lennefors, 2000). BNYVV Isolate, die zusätzlich eine RNA5 besitzen, wurden erstmals im französischen Pithiviers, dem Namensgeber des P-Pathotyps (Koenig et al., 1997) und in Kasachstan (Koenig und Lennefors, 2000) nachgewiesen. In darauf folgenden Untersuchungen wurden RNA5 tragende Isolate auch in Großbritannien (Harju et al., 2002), China (Koenig und Lennefors, 2000) und Japan (Miyanishi et al., 1999) nachgewiesen. BNYVV P-Pathotyp Isolate weisen im Vergleich zu den A- und B-Pathotypen eine höhere Pathogenität auf (Tamada et al., 1996; Miyanishi et al., 1999) und zeigen einen höheren Virustiter (Tamada et al., 1996; Heijbroek et al., 1999; Pferdmenges und Varrelmann, 2008). Schirmer et al. (2005) bezeichneten japanische RNA5 tragende Isolate als J-Pathotypen auf Grund von Sequenzvariabilität bei RNA5 und P26 gegenüber den BNYVV P-Pathotypen. 


\subsubsection{Pathogenitätsfaktor P25 - Einfluss, Tetradenkompositionen und dessen Bedeutung}

Eine besondere Bedeutung bezüglich der Pathogenität der Virusisolate kommt der RNA3 des BNYVV zu. Das auf ihr kodierte Protein P25 ist wie zuvor beschrieben neben der Symptomausprägung an Zuckerrüben (1.2.) auch für die Ausbildung von nekrotischen Lokalläsionen auf dem experimentellen Wirt C.quinoa verantwortlich (Tamada et al., 1989).

P25 hat in seinem natürlichen Wirt, der Zuckerrübe, Einfluss auf die Intensität der Symptomausprägung (Bildung von Seitenwurzeln und Blattvergilbung, Verbräunung der Leitbahnen) und die Virusverbreitung innerhalb des Wurzelsystems (Tamada et al., 1989; Koenig und Stein, 1990; Commandeur et al., 1991, Koenig et al., 1991; Jupin et al., 1991; Jupin et al., 1992). In anfälligen Zuckerrübensorten ist eine vollständige Virusausbreitung nur dann möglich, wenn P25 anwesend ist (Koenig und Burgermeister, 1989; Koenig und Stein, 1990). In sogenannten teilresistenten Zuckerrübengenotypen kann BNYVV nur die Seitenwurzeln infizieren, sich aber nicht weiter in die Hauptwurzel ausbreiten (Tamada et al., 1999). Untersuchungen von Chiba et al. (2008) zeigten bei Zuckerrübenblatt-Inokulationen von anfälligen und resistenten Genotypen (Rizor), dass es entweder zu einer Infektionsresistenz in Form von ausbleibenden Symptomen oder zum Auftreten einer hypersensitiven Reaktion (HR) in Form von nekrotischen Läsionen kommen kann, wenn RNA3 und somit auch P25 anwesend ist.

Die Replikation des BNYVV findet im Cytoplasma statt. Es konnte mittels ImmunoGold Elektronenmikroskopie festgestellt werden, dass P25 sowohl im Cytoplasma, als auch im Zellkern von infizierten Zellen nachweisbar ist (Haeberlé und StussiGaraud, 1995). Des Weiteren haben Vetter et al. (2004) gezeigt, dass P25 ein „nuclear shuttle“ Protein ist. Mittels konfokaler Laserscanning Mikroskopie konnten ein „nuclear localisation signal“ (NLS), und ein „nuclear export signal“ (NES) identifiziert werden (Kapitel 2, Abb. 4). GFP::P25 Fusionen aus dem Virus-Wildtyp und künstlich hergestellten P25 Virusmutanten bewiesen, dass das NLS sich an der N-terminalen Hälfte des P25 Proteins befindet. Die Position des NES an Cterminalen Hälfte wurde mittels Alaninscanning-Mutagenese charakterisiert. Die Fähigkeit des P25, sich sowohl im Cytoplasma, als auch im Zellkern aufzuhalten, 
gibt Hinweise auf eine mögliche Korrelation mit der verstärkten Symptomausprägung in C. quinoa.

P25 ist ein hoch konserviertes Protein, das hauptsächlich in der Aminosäuretetrade As 67-70 Sequenzunterschiede zeigt (Schirmer et al., 2005; Acosta-Leal et al., 2008; Chiba et al., 2008; Koenig et al., 2008) (Kapitel 2, Tabelle 1). Des Weiteren wurden auch as 135 als weitere, stark variable Position beschrieben (Rush et al., 2006). Liu et al. (2005) vermuteten einen Zusammenhang zwischen der Aminosäurezusammensetzung der Tetrade an den Positionen as67, as68 und der Pathogenität bzw. Aggressivität des BNYVV, die im amerikanischen Imperial Valley zu erhöhten Virusgehalten in Rz1 resistenten Sorten führte. In weiteren Untersuchungen konnte diese Beobachtung jedoch nicht bestätigt werden (Liu und Lewellen, 2007). Die Bedeutung dieser Tetrade wurde auch durch mechanische Blattinokulation von resistenten $B$. maritima unterstützt (Tamada, 2007). Eine weitere Aminosäure an der Position as 179 ist ebenfalls für die Blattresistenzreaktionen in Zuckerrübe verantwortlich (Chiba et al., 2008). Die derzeit bekannten Aminosäuretetraden sind in Kapitel 2, Tabelle 2 in einem Überblick zusammengestellt.

\subsection{Methoden zum Nachweis von Protein-Protein Interaktionen}

Proteine steuern nahezu sämtliche Vorgänge in lebenden Zellen und interagieren dabei mit anderen Proteinen, um ihre Funktionen erfüllen zu können. Diese Proteinwechselwirkungen sind als Basis biologischer Prozesse für alle Aspekte des Lebens essentiell (Alberts, 1998; Bader et al., 2003).

Insofern ist ein wichtiger Bestandteil für die Aufklärung der Funktion eines Proteins die Identifizierung von Proteinen, die mit ihm interagieren. Im folgenden Abschnitt wird ein Überblick über die im Rahmen dieser Arbeit angewendeten Methoden zur Identifizierung und zum Nachweis von Protein-Protein Interaktionen sowie ein kurzer Einblick über das Spektrum weiterer möglicher Methoden gegeben. Differenzierte Vergleiche über die Möglichkeiten und Grenzen der jeweiligen Systeme sind in aktuell erschienenen Übersichtsartikeln (Bhat et al., 2006; Lalonde et al., 2008; Miernyk und Thelen, 2008) ausgeführt. 


\subsection{1. „Yeast two-hybrid" Systeme}

"Yeast two-hybrid“ (YTH), im deutschen als Zwei-Hybrid-System bekannt, ist eine in vivo Methode zur Analyse von Protein-Protein Interaktionen und wurde erstmalig von Fields und Song (1989) beschrieben. Das Grundprinzip dieses ersten YTH nutzt den modularen Aufbau von Transkriptionsfaktoren aus zwei voneinander separierbaren Domänen und identifiziert Proteininteraktionen mittels rekonstituierter Transkriptionsaktivierung von einem oder mehreren Reportergenen. Transkriptionsfaktoren bestehen aus zwei Einheiten, die als DNA bindende Domäne $(\mathrm{BD})$ und DNA aktivierende Domäne $(\mathrm{AD})$ räumlich und funktionell voneinander getrennt werden können (Fields und Song, 1989; Chien et al., 1991). Um die Transkription zu aktivieren muss eine physikalische Interaktion zwischen beiden Domänen bestehen, denn keine der beiden Domänen ist allein zur Transkriptionsaktivierung befähigt. Die beiden Domänen werden mit den auf Interaktion zu überprüfenden Proteinen als translationale Fusionen exprimiert, d.h. es werden ein Köderprotein $X$ (,bait") durch Fusion mit der DNA-bindenden Domäne und ein Beuteprotein $Y$ (,prey“) durch Fusion mit der transkriptionsaktivierenden Domäne erzeugt. Kommt es zu einer Interaktion der Proteine $X$ und $Y$, so dimerisieren die beiden Domänen $B D$ und $A D$. Der durch die Interaktion rekonstituierte Transkriptionsfaktor bindet strangaufwärts an die Bindungsstelle einer Promotorregion („upstream activating sequence“, UAS) für die aktivierende Domäne, welche die Transkription der Reportergene aktiviert. Im ursprünglichen System von Fields und Song (1989) wurde nur ein einzelnes Reportergen, das lacZ, für die Selektion verwendet. In den heute verfügbaren YTH Systemen wird eine Kombination aus mehreren Selektionsmarkern genutzt (Causier und Davies, 2002). Dazu gehören zum einen sogenannte Auxotrophiemarker, die Enzyme der Biosynthese einzelner Aminosäuren (z.B. Histidin, Leucin) kodieren und auf entsprechenden Mangelmedien eine Selektion von Interaktionskandidaten erlauben. Zum anderen werden zusätzliche Marker, wie lacZ, gusA oder gfp benutzt, um über deren visuell erfassbare Reportergenaktivität zu selektieren. Dabei werden diese Selektionsmarker nach ihrer Lokalisation unterschieden. Diese liegen als chromosomales Reportergen (Leu2, lacZ, ADE2, HIS3) oder auf Plasmiden (GFP) kodiert vor. Durch die 
Verwendung von mindestens zwei Reportergenen wird eine zuverlässigere Bestätigung der Protein-Protein-Interaktion gewährleistet.

Als Transkriptionsfaktoren finden in YTH-Systemen das aus Saccharomyces cerevisiae stammende Gal4-Protein sowie alternativ das Repressorprotein LexA (als BD) in Kombination mit dem B42-Protein (als AD), die beide aus Escherichia coli stammen (Gyuris et al., 1993), Anwendung. Ein Vorteil LexA-basierender YTH-Systeme liegt in der Möglichkeit die Sensitivität ihres Auxotrophiemarkers durch die Anzahl der LexA Operatorsequenzen innerhalb des Promotors zu verändern. Dieser kann zwischen zwei und sechs Kopien liegen, wobei sich die Sensitivität mit steigender Kopienanzahl erhöht. Ein weiterer Vorteil LexA basierender YTH Systeme ist der prokaryotische Ursprung der Interaktionsdomänen LexA und B42, die im Gegensatz zum eukaryotischen Gal4 weniger falsch-positive Interaktionen verursachen (van Criekinge und Beyaert, 1999).

Im Folgenden soll ein kurzer Überblick über verschiedene YTH-Systeme gegeben werden.

Mayer et al. (1999) entwickelten ein YTH-System unter Nutzung des Kupferinduzierbaren Transkriptionsfaktors ACE1, welcher ähnlich dem Gal4 in AD und BD geteilt wurde und anschließend mit den, auf Interaktion zu testenden Proteinen fusioniert wird. Voraussetzung für dieses, auf der Nutzung eines Kupferresistenzgen-basierenden YTH Systems ist, dass Kupfer über das Kulturmedium verfügbar ist, damit die Funktionalität und DNA-Bindungsfähigkeit des Transkriptionsfaktors gegeben ist. Zur Absicherung und Bestätigung der Interaktion verfügt dieses System zusätzlich über ein ebenfalls chromosomal kodiertes kupferinduzierbares $g f p-G e n$, welches durch den rekonstituierten Transkriptionsfaktor ACE1 induziert wird, nachdem durch eine bereits erfolgte ACE1 induzierte Kupferresistenzgenexpression die Interaktion durch Viabilität der Hefezellen selektiert wurde.

Ein weiteres System zur Identifizierung von Protein-Protein-Interaktionen in Anlehnung an das YTH ist das Cytoplasma-basierende "SOS Recruitment" System (SOS), welches auf der Rekonstituierung des Ras („Rat sarcoma“) Signalweges basiert (Aronheim et al., 1997). Die Proteininteraktionen werden in 
einem temperatursensitiven Hefestamm untersucht, dem es nur bei erfolgreicher Proteininteraktion möglich ist bei höheren Temperaturen zu wachsen. Die zu untersuchenden Proteine („bait“) werden mit dem Protein hSos, einem Protein der RAS-Hitzestressantwort, fusioniert. Das „prey“-Protein wird mit einem Myristylierungssignal fusioniert, welches die Fähigkeit der Membranverankerung vermittelt. Interagieren "bait“ und "prey“ miteinander, so kommt es zu einer Membranverankerung von hSos, die über eine Signalkaskade ein Hefewachstum bei $37^{\circ} \mathrm{C}$ ermöglicht.

Das „SOS recruitment" System weißt den besonderen Vorteil auf, dass bei diesem System die Protein-Protein-Interaktionen im Cytoplasma erfolgen und kein Transport der zu untersuchenden Fusionsproteine in den Zellkern erfolgen muss. Daraus leitet sich die besondere Eignung dieses Systems für Untersuchungen mit Membranproteinen und Proteinen, die auf post-translationalen Modifikationen im Cytoplasma angewiesen, ab.

Das Split-Ubiquitin System nutzt das Polypeptid Ubiquitin zur Proteininteraktion (Varshavsky, 1997). Dabei erfolgt durch Proteininteraktion eine Komplementierung des separierten Ubiquitin-Moleküls und veranlasst so den Transport zum 26S Proteasom. Dabei wird das Ubiquitin durch Ubiquitin-spezifische Proteasen wieder freigesetzt und ins Cytoplasma zurückgeführt. Zur Untersuchung der Interaktion von zwei Proteinen, werden die zu testenden Proteine mit den Ubiquitindomänen fusioniert. Nach Rekonstituierung durch Protein-Interaktion wird ein Reporterprotein durch Abspaltung vom Interaktionskomplex dem Zellkern zugeführt und so die Transkription (z.B. des Transkriptionsfaktors LexA) aktiviert.

\subsubsection{Schwierigkeiten und Adaptionen von Yeast two-hybrid Systemen}

Schwierigkeiten bei der Nutzung von YTH-Methoden für die Identifizierung von Proteininteraktionen ergeben sich, wenn verwendete Köderproteine eigenständig die Transkription aktivieren und dadurch nicht einsetzbar sind (Transkriptionsaktivatoren). Falsch-positive Interaktionen, die in YTH Interaktionen auftreten, können zum Teil anhand ihrer Funktion vermutet werden, da diese bei YTH Interaktionen immer wieder zu finden sind. Dazu zählen u.a. "heat shock“ Proteine, Mitochondrien-Proteine oder auch ribosomale Proteine (Hengen, 1997) 
Ein weiteres Problem ist das nicht zustande kommen von Interaktionen. Es muss immer berücksichtigt werden, dass z.B. Interaktionen, die im Normalzustand im Zytosol oder an der Zellmembran gefunden werden zu keiner Interaktion im Hefezellkern führen (Colas und Brent, 1998). Viele Proteine, die im YTH System auf Interaktion getestet werden, kommen aus anderen Zellkompartimenten und zeigen eine veränderte oder unvollständige tertiäre Struktur und verhindern somit eine mögliche Interaktion. Weiterhin wurden Interaktionen mit Membranproteinen als problematisch identifiziert (Xia et al., 2006). Dies gründet sich auf Beobachtungen bei Fusionen von Membranproteinen mit der aktivierenden Domäne. Dabei kann es zu Komplikationen durch Membranen kommen, die diesen Fusionsproteinen den Eintritt in den Zellkern verweigern und somit die Rekonstitution des Transkriptionsfaktors im Zellkern und den zugehörigen Interaktionsnachweis unmöglich machen. Des Weiteren kann es bei der Expression von Membranproteinen in E. coli zu toxischen Reaktionen kommen, die folglich zu einer nicht repräsentativen Anzahl von Membranproteinen in cDNA Expressionsbibliotheken für YTH Screens führen (Frommer und Ninnemann,1995). Protein-Protein Interaktionen mit solchen Membranproteinen werden in der Regel anschließend durch Selektionsschritte als falsch-positive identifiziert. Zusätzlich muss berücksichtigt werden, dass weitere potentielle falsch-positive Interaktionen von Proteinen auftreten, die im Zellzyklus räumlich oder zeitlich getrennt vorliegen und deshalb im ursprünglichen Organismus niemals eine Interaktion zeigen.

Einige dieser Probleme des YTH Systems wurden in adaptierten Systemen behoben. Ein Beispiel dafür ist das „yeast three-hybrid“ (Y3H) System. Prinzipiell ist der Ablauf entsprechend dem des YTH Systems. Zwei auf Interaktion zu prüfende Proteine werden wie zuvor beschrieben an $A D$ und $B D$ eines Transkriptionsfaktors (z.B. Gal4) fusioniert und mit einem zusätzlichen dritten Protein, welches ein NLS besitzt, zur Interaktion eingesetzt. Zur Aktivierung des Reportergens kann es im $\mathrm{Y} 3 \mathrm{H}$ nur kommen, wenn ein Komplex bestehend aus allen drei Komponenten vorliegt (Causier und Davies, 2002). Ein Vorteil dieses Assays ist, dass Interaktionen, die in YTH Untersuchungen ausbleiben, durch die Anwesenheit eines dritten Proteins möglicherweise erkannt werden können. Denn viele zelluläre Prozesse können nur durch die Anwesenheit mehrerer Proteine 
zustande kommen. Außerdem lassen sich die Interaktionen kleinerer Moleküle ( $<10 \mathrm{kDa}$ ) durch ein solches System realisieren (Causier und Davies, 2002; Suter et al., 2008).

Y3H bietet auch die Möglichkeit Interaktionen zwischen RNA und Proteinen in vivo nachzuweisen. Interaktionen dieser beiden Komponenten kommen in vielen biologischen Prozessen, u.a. bei der Virusreplikation vor. Dabei wird im $\mathrm{Y} 3 \mathrm{H}$ als dritte Interaktionskomponente ein Hybrid-RNA-Molekül verwendet. Für die Interaktion werden zwei Komponenten verwendet. Ein Hybrid-Protein bestehend aus einem gut charakterisierten RNA-Molekül (z.B. Hüllprotein des Bakteriophagen MS“) mit Bindung an ein bekanntes Protein wird mit einem anderen Hybrid-Protein bestehend aus einem unbekannten RNA-Molekül und einem zweiten Protein auf Interaktion geprüft (Kraemer et al., 2000; Zhang et al., 2000; Jaeger et al., 2004; Hook et al., 2005).

Die Umsetzung des YTH in Zellen anderer Herkunft führte zu Systemen, wie dem "Mammalian two-hybrid“ (M2H) oder dem „Bacterial two-hybrid“ (B2H). Dabei basiert das letztere, bakterielle System ebenfalls auf Transkriptionsaktivierung, entsprechend dem YTH (Joung et al., 2000; Serebriiskii et al., 2000). Wesentlicher Vorteil des B2H im Vergleich zum Hefesystem ist die Möglichkeit des schnelleren Interaktionsnachweises. Dies begründet sich auf leichten Handhabung und der sehr schnellen Wachstumsrate des Bakteriums E. coli (Causier und Davies, 2002). Eine weitere Möglichkeit Protein-Protein Interaktion zu testen, bietet das $\mathrm{M} 2 \mathrm{H}$ (Dang et al., 1991; Vasavada et al., 1991). Dieses System basiert ebenfalls auf dem Prinzip der Proteinfusionen mit Interaktionsdomänen entsprechend dem YTH. $\mathrm{M} 2 \mathrm{H}$ bietet somit die Möglichkeit Interaktionen in einem anderen zellulären Hintergrund zu prüfen. Im Vergleich zu YTH bietet es den Vorteil, das komplexe posttranslationale Modifikationen, die für die Faltung von Proteinen nötig sind in tierischen Zellen korrekter erfolgen als in Hefezellen. Die Anwendung dieses System für pflanzenbiologische Untersuchungen ist aber aufgrund der mit $\mathrm{M} 2 \mathrm{H}$ verbundenen höheren Kosten nur bedingt geeignet (Causier und Davies, 2002).

\subsubsection{Systeme für die Bestätigung von Protein-Protein Interaktionen}

Aufgrund der beschriebenen Charakteristika von Hefesystemen und der damit verbundenen Möglichkeit der Selektion falsch-positiver Interaktionen sollten 
Protein-Protein Interaktionen immer durch ein zusätzliches ProteininteraktionsAssay bestätigt werden. Dabei ist es empfehlenswert eine Methode zu nutzen, die unter anderen Bedingungen z.B. in vitro oder in planta durchgeführt wird. Von diesen Systemen soll im Rahmen dieses Abschnitts ein kurzer Überblick gegeben werden.

Zu den in vitro Proteinnachweisen zählen u.a. die Verfahren der CoImmunopräzipitation (Co-IP), wie auch in vitro Säulenbindungsassays („GST-pulldown"). Bei diesen physikalisch-biochemischen Methoden werden die Nachweise mit Hilfe von Antikörpern durchgeführt.

Die Co-IP basiert auf der Bildung von Protein-Protein Interaktionen gefolgt von einem Nachweis durch spezifische Antikörperbindung an eines der Interaktionsproteine (Vitale, 2002). Der Antikörper ist in der Lage, dass gesuchte Protein, welches mit dem zweiten Protein interagiert, zu erkennen. Als Resultat bildet sich ein Protein-Protein-Antikörper-Komplex. Durch Waschschritte nach Protein-Komplex-Bindung werden diese Protein-Protein-Interaktionen von nicht gebundenen Proteinen getrennt. Zum Nachweis der positiven Protein-Protein Interaktionen wird ein immunologischer Nachweis durchgeführt. Für diesen werden z.B. Hämagglutinin (HA)- oder c-myc-tag mit einem der interagierenden Proteine fusioniert und anschließend mit spezifischen Antikörpern bei Proteinkomplexbildung nachgewiesen.

Der Glutathion-S-Transferase (GST) Bindungsassay („pull-down“) ist eine weitere Möglichkeit, um Protein-Protein Interaktionen in vitro zu identifizieren (Kaelin et al., 1991). Erste Anwendungen zur Expression von GST-Fusionsproteinen in E. coli wurden bereits 1988 von Smith und Johnson (1988) beschrieben. Die ProteinProtein Interaktion basiert auf einer Fusion des zu untersuchenden Proteins mit Glutathion-S-Transferase (GST), die in E. coli synthetisiert werden und einer Bindung an Sepharose für den anschließenden Antikörpernachweis. Im „pulldown" bindet die GST an Glutathion. Um die, an das Glutathion gebundenen Proteinkomplexe zurückzugewinnen, wird reduziertes Glutathion hinzugefügt, das aufgrund hoher Affinität zu GST eine Freisetzung der Proteinkomplexe verursacht. Liegt eine Proteininteraktion zweier Proteine vor, so werden die gemeinsam an die Sepharose gebundenen Proteinkomplexe anschließend im immunologischen Nachweis mittels spezifischer Antikörper detektiert werden. 
„Fluorescence resonance energy transfer" (FRET) ist ein in vivo System, das zur Identifikation sowohl intra- als auch intermolekularer Interaktionen in lebenden Zellen verwendet wird (Kuroda et al., 2006). FRET basiert auf einem physikalischen Prozess, bei dem Energie eines Fluoreszenzfarbstoffes, welcher sich in einem angeregten Zustand befindet (Donor) auf einen zweiten Fluoreszenzfarbstoff (Akzeptor) weitergegeben wird. Diese energetische Wechselwirkung kann für Proteininteraktionen nutzbar gemacht werden. Dazu wird ein Protein mit einem Donorfluoreszenzmarker, das andere mit dem zugehörigen Akzeptorfluorophor ausgestattet. Damit die Möglichkeit der Energieübertragung und somit zur Interaktion gegeben ist, ist eine Überlappung des emittierenden Spektrums des Donors mit dem absorbierenden Spektrum des Akzeptors die Voraussetzung (Lalonde et al., 2008). Dabei stehen mehrere verschieden fluoreszierende Proteine wie GFP, YFP etc. zur Verfügung, die zuvor auf die Verwendbarkeit ihrer Spektren überprüft werden sollten. Eine genaue Darstellung möglicher Donor-Akzeptor Kombinationen wurde von Wallrabe und Periasamy (2005) zusammengestellt. Interagieren Proteine miteinander, so kann ein FRET Signal detektiert werden. Dabei können sogar Rückschlüsse auf die Nähe der beiden Proteine gezogen werden, da das FRET-Signal bei geringer Entfernung der Proteine wesentlich stärker ist, als bei weiter entfernten Proteinen.

"Bimolecular fluorescence complementation" (BiFC) oder Split-System ist eine in den letzten Jahren entwickelte Methode, die es leicht und schnell möglich macht, Protein-Protein-Interaktionen in vivo und in planta durch Rekonstitution von Fluoreszenzmarkergenen zu detektieren (Hu et al., 2002). Erstmalig wurde BiFC zum Nachweis der Lokalisation von Interaktionen zwischen Transkriptionsregulatoren der bzip-Familie („basic region-leucine zipper") angewendet ( $\mathrm{Hu}$ et al., 2002). Dieses ursprüngliche System basiert auf der Zusammenführung von zwei nichtfluoreszierenden Peptidhälften des "yellow fluorescent protein" (YFP) zu einem funktionellen Chromophor, sobald die Proteineinheiten in direkte räumlich Nähe gebracht werden. Die Rekonstitution des YFP erfolgt durch die Expression von amino- bzw. carboxylterminalen Fusionen von miteinander interagierenden Proteinen an den Chromophorhälften (Hu et al., 2002; de Virgilio et al., 2004). BiFC wurde u.a. in Protoplasten von Arabidopsis thaliana (Bracha-Drori et al., 2004) sowie in Zellen von Allium cepa 
erfolgreich angewendet (Bracha-Drori et al., 2004; Walter et al., 2004). Die Nutzung der Methode wurde ebenfalls durch transiente Agroexpression in Parenchymzellen von Nicotiana benthamiana gezeigt. Walter et al. (2004) demonstrierten hier die Homo-Dimerisierung des Transkriptionsfaktors bzip. Ein deutlicher Vorteil des Fluorophor-basierenden Splitsystems ist, dass keine exogenen Farbstoffe oder Färbetechniken angewendet werden müssen und die Fluoreszenz schnell und stabil zu beobachten ist.

Des Weiteren wurden Systeme, die Kombinationen verschiedener Fluoreszenzproteine verwenden, entwickelt, um Interaktionen mehrerer Proteine zu charakterisieren, denn viele zelluläre Proteine haben die Möglichkeit mit einer Vielzahl von Proteinen zu interagieren. Um Interaktionen mehrerer Proteine in derselben Zelle sichtbar zu machen, wurde das "Multicolor BiFC" System entwickelt (Hu und Kerppola, 2003). Dieses System basiert auf der Zusammenführung von Fluorophor-Hälften, (s.o. BiFC System), durch die Verwendung mehrerer unterschiedlicher Farbspektren. Das "Multicolor BiFC System" ermöglicht die Untersuchung der Interaktion mehrerer Proteine zum gleichen Zeitpunkt mit demselben Protein. Darüber hinaus kann Konkurrenzverhalten, d.h. Interaktion von zwei Proteinen mit einem dritten gemeinsamen Partner analysiert werden (Hu und Kerppola, 2003; Jach et al., 2006; Lee et al., 2008). Eine Übersicht über die Möglichkeiten und deren Anwendungen von den unterschiedlichen BiFC Systemen wurde von Kerppola (2008) ausführlich dargestellt.

\subsubsection{Untersuchungen von Protein-Protein Interaktionen zur Charakterisierung von Virus-Wirt-Beziehungen}

Von den zahlreichen methodischen Möglichkeiten zum Nachweis von Protein-Protein Interaktionen stellt das YTH System neben der massenspektrometrischen Analyse nach wie vor die am besten geeignete Methode dar, um effiziente Hochdurchsatz-Durchmusterungen auf Proteinebene durchzuführen (von Mehring et al., 2002). YTH ist besonders geeignet für die Untersuchung gesamter Transkriptome z.B. von cDNA Bibliotheken (Legrain und Selig, 2000; Uetz und Hughes, 2000). Die unvermeidbaren Falsch-positiven und 
Falsch-negativen Ergebnisse, die durch auftretenden falsch-positiven und falschnegativen Interaktionen im YTH entstehen, können durch nachfolgende Sequenzanalysen und Verifizierungen von Interaktionsreaktionen in YTHunabhängigen Methoden reduziert werden (1.3.3.).

Viele Beispiele aus der Literatur zeigen, dass YTH eine effektive Methode ist, um das Zusammenspiel der Virus-Wirt Interaktionen auf Proteinebene zu charakterisieren und durch das Screening von cDNA Bibliotheken näher zu bestimmen.

Die Helferkomponenten-Proteasen (HC-Pro) der Potyviren sind in diesem Zusammenhang des Öfteren in YTH-basierenden Untersuchungen verwendet worden. Das HC-Pro des potato virus A wurde in einem Gal4 basierenden Hefesystem auf Interaktion mit einer Kartoffel cDNA Bibliothek überprüft. Resultierend konnte ein RING Finger Protein (HIP1) identifiziert werden, welches an der viralen Infektion der Pflanze beteiligt sein könnte (Guo et al., 2003). Daraus resultierend ist eine Funktion beim Proteinabbau ebenfalls denkbar (Freemont, 2000).

Die HC-Pro des potato virus $\mathrm{Y}$ (PVY) wurde zur Durchmusterung einer CDNA Bibliothek aus N. tabacum verwendet. Der als "chloroplast division-related protein" (AtMinD) identifizierte Kandidat zeigt Homologie zum Polypeptid NtMinD, welches für die Chloroplastenteilung verantwortlich ist (Jin et al., 2007). Die Autoren vermuteten, dass die HC-Pro-NtMinD Interaktion zur Hemmung der Chloroplastenteilung führt und somit die Chloroplastenanzahl in infizierten Pflanzen sinkt, was das Auftreten von Chlorosen zur Folge haben kann (PompeNovak et al., 2001). Als weitere Interaktionspartner der HC-Pro des PVY wurden in Untersuchungen von Jin et al. (2008) drei Untereinheiten des 20S Proteasom von A. thaliana identifiziert.

Das am Zell zu Zell Transport beteiligte NSm Protein des tomato spotted wilt virus (TSWV) wurde auf Interaktion gegen verschiedene cDNA Bibliotheken aus Tomate, Tabak und A. thaliana in Gal4 basierenden Systemen geprüft (Soellick et al., 2000; von Bargen et al., 2001; Paape et al., 2006). Dabei konnte u.a. eine Übereinstimmung durch die Identifikation von Proteinen der DNaJ Familie gefunden werden. DNaJ Proteine sind Schlüsselregulatoren der Hitzeschockproteine Hsp70 Chaperone, Proteine die u.a. für Proteinfaltung 
verantwortlich sind. Diese Interaktion deutet darauf hin, dass eine mögliche Beteiligung am Hsp70 abhängigen Mechanismus für das TSWV vorliegt. Des Weiteren wurde ein Protein aus A. thaliana als Interaktionspartner identifiziert, welches am intra- und interzellulären Transport in Zellen beteiligt ist und somit die Funktion des Zell zu Zell Transport des NSm Proteins bestätigt (Soellick et al., 2000; von Bargen et al., 2001; Paape et al., 2006).

Eine Bibliotheksdurchmusterung wurde mit dem PO Protein des beet western yellows virus (BWYV) im Gal4 basierenden YTH System gegen eine cDNA Bibliothek von A. thaliana durchgeführt (Pazhouhandeh et al., 2006). P0 ist silencing suppressor und Pathogenitätsfaktor des BWYV. Die Autoren konnten im Rahmen dieser Arbeit herausstellen, dass PO ein F-box Motiv besitzt und zusätzlich mit zwei Proteinen der E3 Ligase Interaktion zeigt. Als Schlussfolgerung dessen wird P0 die Funktion eines F-box Proteins zugesprochen, welches für die Rekrutierung von Abbauproteinen verantwortlich ist.

Das Cl-Protein des plum pox virus (PPV) wurde als virales Protein für einen LexA basierenden YTH Screen gegen eine cDNA Bibliothek aus N. benthamiana verwendet. Als entscheidendes Ergebnis konnte die Interaktion mit einem Protein des Photosystems I, PSI-K identifiziert werden. Die Interaktion des $\mathrm{Cl}$ Proteins mit diesem Protein aus Chloroplasten zeigte, dass PSI-K einen negativen, hemmenden Einfluss auf die virale Infektion des PPV hat (Jimenez et al., 2006).

Das Hüllprotein P2 des rice dwarf virus konnte im Gal4 Hefesystem beim Durchmustern einer cDNA Bibliothek aus Reis auf Protein-Protein Interaktion untersucht werden. Resultierend wurde eine Interaktion mit einer Reis "entkaurene" Oxidase identifiziert, die an der Biosynthese des Phytohormons Gibberellin beteiligt ist. Aufgrund des Symptoms der Zwergwüchsigkeit, das durch das Virus verursacht wird und den nachgewiesenen Interaktionsergebnissen, schlussfolgern die Autoren, dass P2 eine entscheidende Rolle für die Verringerung des Pflanzenwachstums spielt (Zhu et al., 2005).

Die Ergebnisse der hier nur in Auszügen, beispielhaft vorgestellten Arbeiten von Protein-Protein Interaktionen bei der Durchmusterung pflanzlicher cDNA-Banken mit pflanzenviralen Proteinen als "bait“ zeigen, dass Hinweise auf funktionelle Wechselwirkungen in Virus-Wirt-Interaktionen aus diesen Untersuchungen 
abgeleitet werden können. Es ist somit denkbar, dass die Durchmusterung einer cDNA Bibliothek aus Zuckerrübe mit dem Pathogenitätsfaktor P25 Rückschlüsse auf den bislang unvollständig geklärten Resistenzmechanismus der Pflanze bzw. Pathogenitätsmechanismus des Virus ermöglicht.

\subsection{Zielstellung dieser Arbeit}

Das Ziel der im Rahmen dieser Arbeit durchgeführten Untersuchungen bestand in der Charakterisierung des Pathosystems BNYVV-Zuckerrübe bezüglich der noch ungeklärten Resistenz- bzw. Pathogenitätsmechanismen.

P25 wurde als Avirulenzprodukt des BNYVV identifiziert (Chiba et al., 2008). Dadurch bestand das Ziel der Arbeit in der Identifizierung von Interaktionen zwischen dem Proteom einer BNYVV-infizierten $R z 2$ resistenten Zuckerrübenlinie und dem viralen Pathogenitätsfaktor P25. Daraus sollte ein besseres Verständnis des Funktionsmechanismus von P25 in Zuckerrübe resultieren.

Die Identifizierung von Protein-Protein-Interaktionen wurde in einem LexAbasierenden YTH Screen durchgeführt. Dazu wurde in Kooperation mit vertis Biotechnologie AG (Freising) eine cDNA-Zuckerrübenbibliothek erstellt und auf Proteininteraktionen mit P25 durchmustert. Die identifizierten potentiellen Interaktionspartner des P25 sollten in Datenbankanalysen auf ihre funktionelle Identität analysiert und hinsichtlich ihrer biologischen Relevanz für die Virus-WirtInteraktion bewertet werden. In weiterführenden Untersuchungen sollten aus dem Yeast two-hybrid Screen selektierte Interaktionskandidaten mit Hilfe eines zusätzlichen Interaktionsassays auf ihre Wechselwirkung mit P25 verifiziert werden. 


\section{Kapitel 2: Molecular Biology of the Beet necrotic yellow vein virus}

Plant Viruses (2008) Vol. 2(1) 14-24

Claire Peltier ${ }^{1}$, Kamal Hleibieh $^{1}$, Heike Thiel ${ }^{2}$, Elodie Klein ${ }^{1}$, Claude Bragard $^{3}$, \& David Gilmer ${ }^{1^{*}}$

* david.gilmer@ibmp-ulp.u-strasbg.fr

${ }^{1}$ Institut de Biologie Moléculaire des Plantes, laboratoire propre du CNRS (UPR 2357) conventionné avec l'Université Louis Pasteur (Strasbourg 1), 12 rue du Général Zimmer, 67084 Strasbourg, France

2 University of Goettingen, Department of Crop Sciences, Plant Virology, Grisebachstrasse 6, D-37077 Goettingen, Germany

${ }^{3}$ Unité de Phytopathologie, Université Catholique de Louvain, Croix du Sud 2bte3, B1348, Louvain-La-Neuve, Belgium

Abbreviations: BNYVV, Beet necrotic yellow vein virus, CP, coat protein; ORF, open reading frame ; RB, resistance breaking ; TGB, Triple Gene Block.

Key words: Benyvirus, rhizomania, Polymyxa betae, pathogenicity, ICTVdB Virus

\section{ABSTRACT}

Beet necrotic yellow vein virus is the etiological agent of one of the most devastating sugar beet viral diseases: rhizomania. This review describes the molecular biology of the rhizomania disease, the functions of the BNYVV encoded proteins, the consequences of their expression as well as the biology of the BNYVV vector, Polymyxa betae. Root proliferation is an important part of the wellknown characteristics of the viral infection that leads to yield and sugar losses. The extensive use of sugar beet cultivars displaying partial resistance or tolerance against virus infection allows containment of sugar yields. However, such extensive uses also permit viruliferous vector to be amplified and therefore the appearance of resistance breaking isolates. We review as well the defence strategies that may be used against rhizomania. 


\section{INTRODUCTION}

Sugar beet rhizomania possesses the potential to lower the sugar contents in the roots of susceptible sugar beet cultivars up to $20 \%$. However, sugar companies report yield losses of 50 to $70 \%$ during sugar purification (Richard-Molard 1985). Rhizomania was first reported during the fifties in Italy (Canova 1959). Nowadays the disease is present in almost every sugar beet growing area in the world. The etiological agent was discovered by Tamada and Baba in 1973 who demonstrated that rhizomania was induced by the phytovirus named Beet necrotic yellow vein virus, BNYVV (Tamada and Baba 1973). Such pathogen classified among the alphavirus-like supergroup is assigned to the genus Benyvirus (ICTV $\mathrm{dB}$, http://www.ncbi.nlm.nih.gov/ICTVdb/ICTVdB/). BNYVV is transmitted by the soilborne obligate parasite Polymyxa betae Keskin (Keskin 1964), a protist initially classified in the fungus kingdom. $P$. betae is able to form spores that are extremely resistant to biodegradation, drought and pesticides treatment, that allow viruliferous spores to rest for more than two decades in the infested soils. Breeding efforts were carried out in order to maintain the sugar production yields, resulting in the development of sugar beet hybrids partially resistant to BNYVV systemic infection. Such crops are commonly used for commercial production. Their intensive uses among the infested soils applied a positive selection pressure that raised RB isolates. Interestingly, emerging viral species possess sequence variation particularly within RNA-3; the viral component that encodes the pathogenicity determinant p25, involved in root proliferation (Koenig et al. 1991; Tamada et al. 1999).

Actual molecular studies of the rhizomania syndrome tend to reveal the resistance mechanism mediated by the $R z$ resistance gene products as well as the virus induced processes, leading to the root proliferation, particularly by the study of the RNA-3-encoded p25 protein. However, the identification of other P. betaetransmitted viruses associated with the rhizomania syndrome rise new questions about the disease etiology. As an example, Beet black scorch virus has been shown to induce rhizomania-like symptoms (Weiland et al. 2007). 


\section{RHIZOMANIA DISEASE}

Symptoms

The Rhizomania syndrome refers to root madness (Rhizo: root; Mania: madness). Infected sugar beets display more or less a dwarfism that reduces the taproot size, which harbours necrosis (Fig. 1C). Infection shapes a wine-glass-like taproot and induces rootlet proliferations that become necrotic, abundant and fragile. These root symptoms reduced water uptake that provoke leaf fading (Fig. 1a). Sometimes, when the infection becomes systemic, vein yellowing, necrosis and foliar local lesions appear (Fig. 1b). Beet necrotic yellow vein virus was named according to these systemic symptoms.

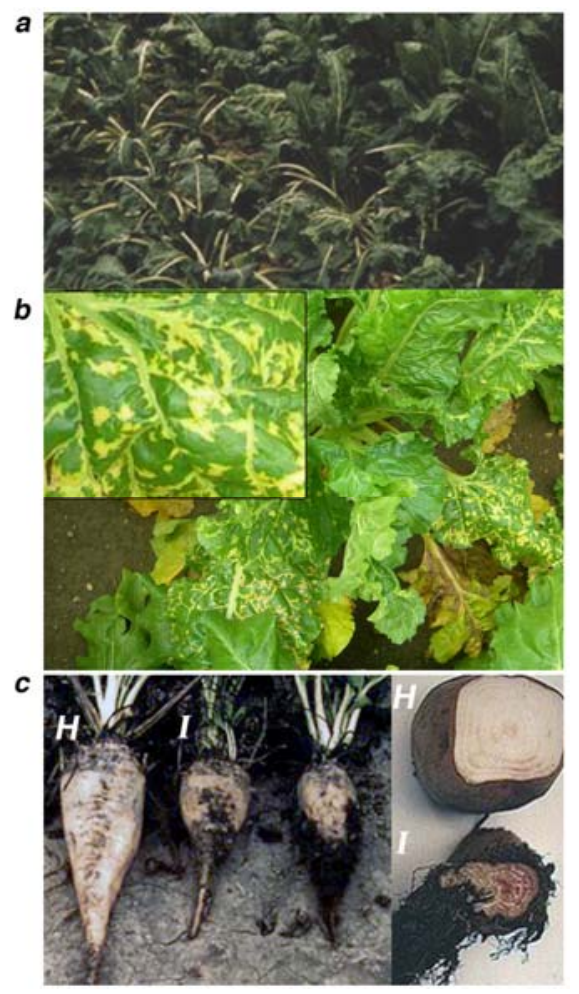

Fig. 1 Symptoms of sugar beet rhizomania. (a) During warm period, water deficiencies induced by rhizomania disease provokes plant wilt. (b) Foliar symptoms are rather rare and correspond to plant systemic infection. Vein yellowing and yellow chlorotic spots are induced by the expression of the RNA-3encoded p25 protein. (c) Typical root symptoms: infected taproot (I) are shorter, wine glass shaped and display characteristic necrosis and root proliferation compared to healthy plant $(\mathrm{H})$. (Photos a and c: INRA-Colmar, b: Institut Technique de la Betterave, Paris) 
Histological and biochemical properties of rhizomania diseased plants

Histological sections performed on infected taproot suggested that the infection and/or the necrosis of lateral roots induce the reprogramming of the pericycle cells to meristematic cells, which might cause the synthesis of new rootlets (Pollini and Giunchedi 1989). Moreover, viral sequences could also induce a modulation of the cellular messenger and protein expression profiles leading to root morphogenesis. Thus, root proliferation favors the viral replication and transmission. Indeed, rootlet cells are the targets of BNYVV vector, the parasite $P$. betae.

The plant hormone auxine plays a major role in plant development and particularly on root morphogenesis. Indol-3-acetic acid assays performed onto susceptible and tolerant sugar beet varieties revealed auxin level three times higher in infected plants (Pollini et al. 1990). Interestingly, tolerant crops possess lower auxin contents than susceptible plants. One of the questions that still need an answer is to determine if auxin variations are the initiator or the consequence of the cellular disorders induced by BNYVV infection. Comparisons of the root transcriptome of healthy beets with rhizomania infected beets lead to the identification of auxin, cell cycle, defence signalling and ubiquitin-related regulated genes (Schmidlin et al. 2008).

\section{BEET NECROTIC YELLOW VEIN VIRUS}

\section{Taxonomy}

BNYVV possesses a multipartite linear positive-sense single-stranded RNA genome that consists of four to five RNAs possessing 5' cap and polyadenylated 3' ends. BNYVV belongs to the supergroup of alphavirus-like and is the type species of the Benyvirus genus, which contains as well the Beet soil-borne mosaic virus (BSBMV, ICTVdB: 00.088.0.01.002) (Lee et al. 2001). BNYVV and BSBMV are rod-shaped, share a similar genomic organization (Lee et al. 2001), host range, and are transmitted by the protist vector $P$. betae. However, BSBMV has only been detected within North America. BSBMV and BNYVV are closely related but are distinct viruses since $R z$ resistant genes have no effect on BSBMV accumulation (Wisler et al. 2003) and no cross reaction with coat protein antisera, nor cross protection have been described. Recent studies demonstrated that 
BNYVV RNA-1 and -2 were able to amplify BSBMV RNA-3 and -4 , but only in the absence of BNYVV small RNAs (Claudio Ratti and David Gilmer, unpublished). Both viruses could compete for similar host factors. Such hypothesis will be tested as soon as full-length infectious clones of BSBMV RNA-1 and -2 will be available.

Tentative members within Benyviruses are Burdock mottle virus (BdMV, ICTVdB: 00.088.0.01.004) (Rush 2003) and Rice stripe necrosis virus (RSNV, ICTVdB: 00.088.0.01.003) (Morales et al. 1999; Van Regenmortel et al. 2000; Fauquet et al. 2005).

Host range

BNYVV infects plants within Amaranthaceae, Chenopodiacea and Tetragoniaceae families. Systemic infection occurs naturally onto Beta vulgaris (sugar beet) and Beta macrocarpa. Nicotiana benthamiana and Spinacia oleracea are systemically infected even in the absence of RNA-3 and -4. On experimental hosts, BNYVV is propagated onto Chenopodium quinoa or Tetragonia expansa that respond to the infection by chlorotic or necrotic local lesions, depending on the inoculum composition (Tamada et al. 1989; Koenig et al. 1991; Jupin et al. 1992).

\section{Structure}

Viral particles display a right-handed helical symmetry (Fig. 2) with a $2.6 \mathrm{~nm}$ pitch, 49 capsid protein subunits per repetition of 4 turns, with each subunit interacting with 4 nucleotides (Steven et al. 1981). The particles are not enveloped and have a diameter of $20 \mathrm{~nm}$ with lengths proportional to the sizes of the encapsidated RNAs, i.e, 390, 265, 105, 89 and 80 nm (Putz 1977; Tamada et al. 1989). Coat proteins constitute about $95 \%$ of the particle weight. The minor coat protein, a CP amber readthrough gene product (CP-RT) is present at one extremity of particles and participates both to the morphogenesis (Schmitt et al. 1992; Haeberle et al. 1994) and to the transmission of the virions (Tamada et al. 1996). 


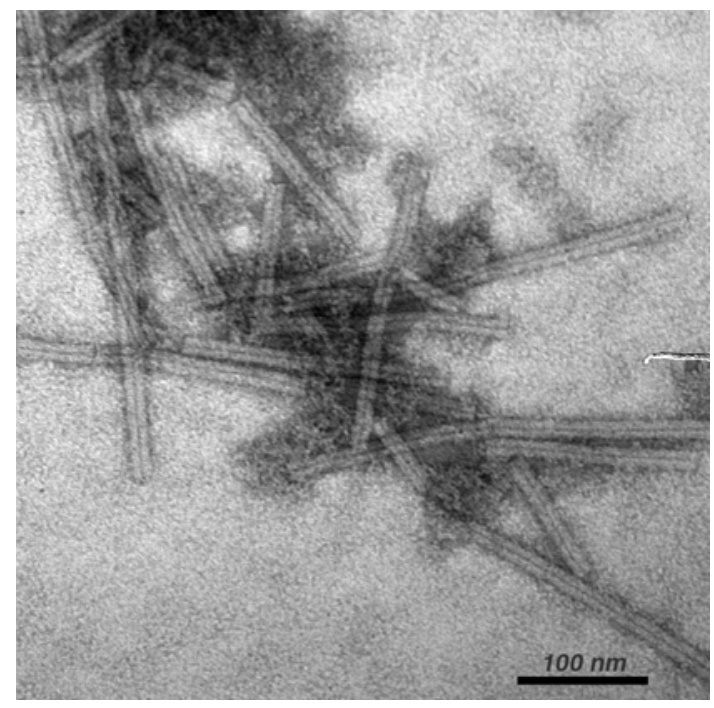

Fig. 2 Immunocaptured BNYVV particles observed by electron microscopy. (Photo M. Erhardt, IBMP).

Genomic organization

BNYVV has a segmented RNA genome composed of 4 to 5 genomic components (Tamada 1999). All components possess a $5^{\prime}$ Cap ( $\mathrm{m}^{7} \mathrm{GpppG}$ ) and a $3^{\prime}$ polyA tail. Sequencing together with the full-length infectious clones (Quillet et al. 1989; Link et al. 2005) permitted to decipher the viral genomic organization and the main functions of virally encoded proteins (Fig. 3).

RNA-1 is involved in the replication of viral RNAs (Gilmer et al. 1992a) and RNA-2 is necessary for encapsidation, cell-to-cell movement and RNA silencing suppression (RNA-2), as proven by protoplast and mechanical infection of leaves. RNA-1 and -2 are necessary and sufficient for the infection following leaf mechanical inoculations where small components are dispensable and, if they are present, can undergo deletion or disappear (Bouzoubaa et al. 1991). In natural infection, however, these small components are required. Indeed, RNA-3 allows the viral amplification in sugar beet roots and its expression influences symptoms (Tamada et al. 1989; Jupin et al. 1992), whereas RNA-4 is involved in viral transmission (Tamada and Abe 1989). Moreover, RNA-4-encoded p31 is described as a root specific silencing suppressor (Rahim et al. 2007). Therefore, BNYVV is a unique virus as it behaves as a bipartite virus when rub inoculated or as a tetra or pentapartite virus in natural infection. Such a property has been utilized to obtain viral expression vectors, named replicons, and derived from 
RNA-3 and RNA-5 (Schmidlin et al. 2005). Such replicons allow the expression of various sequences within infected tissues (Schmidlin et al. 2005).

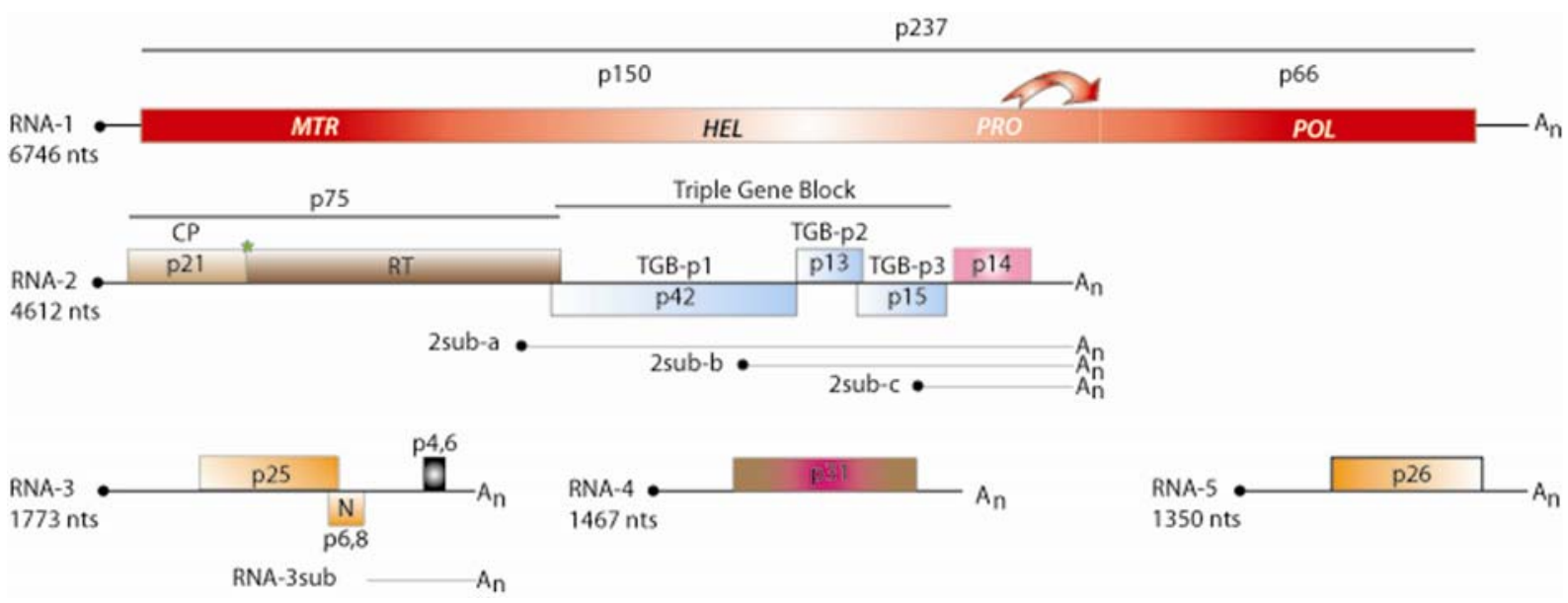

Fig. 3 BNYVV genomic organization. The sizes of the five genomic RNAs are presented. Black dot represents Cap structure and $A_{n}$, the polyadenylated sequence. Squares correspond to ORF. Arrow designates the cis proteolysis of the RNA-1-encoded p237 polyprotein leading to the p150 and the p66 proteins. MTR, Methyltransferase domain; HEL, Helicase domain; PRO, Protease domain; POL, Polymerase domain. Star denotes the CP amber readthrough mechanism leading to the expression of minor CP-RT protein.

Genomic functions

RNA-1 is 6746 nts long (without polyA) and harbours only one open reading frame (ORF). It encodes a $237 \mathrm{kDa}$ polypeptide (Bouzoubaa et al. 1987) that contains consensus methyl-tranferase (MTR), helicase (HEL), papain-like protease (PRO) and polymerase (POL). Autoproteolysis of p237 between the domains PRO and POL leads to two proteins: p150 and p60, which contain respectively the MTR, HEL, PRO and the POL motifs (Hehn et al. 1997). This proteolytic clivage of the replicase protein is the significant feature of the Benyviruses. However, the stoechiometry of replication complex is not known.

RNA-2 is 4612 nts long and encodes for six proteins.

The first cistron drives the synthesis the $21 \mathrm{kDa}$ major capsid protein, CP. In about $10 \%$ of the translation events, CP of amber stop codon is suppressed and the 
resulting readthrough leads to the synthesis of the $75 \mathrm{kDa}$ minor coat protein, CPRT (Niesbach-Klosgen et al. 1990; Haeberle et al. 1994). CP-RT is needed for the viral transmission (Tamada et al. 1996) and for the transient anchoring of the viral particles around mitochondria (Erhardt et al. 2001; Valentin et al. 2005). These latter studies suggest that the viral genome packaging occurs around mitochondria.

Following the structural protein encoding ORFs, a cluster of three genes, partially overlapping, known as "triple gene block" (TGB) ensures the viral cell-to-cell movement. TGB clusters are also found on other plant viral species, including Pomo-, Peclu-, Potex-, Carla- and Hordeivirus (Morozov and Solovyev 2003). For BNYVV, these three proteins are encoded by subgenomic RNA-2sub-a for TGBp1 (42 kDa) and RNA-2sub-b for TGB-p2 (13 kDa) and TGB-p3 (15 kDa) (Gilmer et al. 1992a). TGB-p1 protein contains a helicase domain and is able to bind nucleic acids in vitro (Bleykasten et al. 1996).

Complementation studies of TGB-p1 protein with a virally expressed GFP::TGB-p1 fusion protein permitted to localize TGB-p1 in plasmodesmata only in the presence of the TGB-p2 and -p3 proteins (Erhardt et al. 2000). Moreover, TGB-p2 and -p3 are detected within plasmodesmata only when all the TGB proteins are expressed in the same cell (Erhardt et al. 2005).

ORF VI product encodes for a cystein-rich protein of $14 \mathrm{kDa}$. P14 is expressed from RNA-2sub-c. This protein is involved in the regulation of the virus replication (Gilmer et al. 1992a), enhances the expression of CP protein (Hehn et al. 1995) and acts as a weak silencing suppressor (Dunoyer et al. 2002).

RNA-3 is $1773 \mathrm{nts}$ long and is involved in viral pathogenicity. Its presence exacerbates root and foliar symptoms (Tamada et al. 1989; Jupin et al. 1992). This RNA is also necessary for the long distance movement of the virus (Lauber et al. 1998) and is responsible for the rhizomania phenotype on Beta vulgaris (Tamada et al. 1989; Koenig et al. 1991).

p25

The p25 protein is expressed from RNA-3 and modulates foliar (Jupin et al. 1992) and root symptoms (Tamada et al. 1999). No sequence homology is found with known proteins, except with BNYVV RNA-5-encoded p26, which only shares the

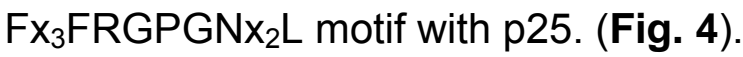


Nucleo-cytoplasmic localization of p25 has been shown (Haeberle and StussiGaraud 1995). Its nuclear addressing involves the N-terminal ${ }_{57}$ KRIRFR $_{62} \mathrm{NLS}$ (Vetter et al. 2004). Moreover, a nuclear export sequence (NES), ${ }_{169}$ VYMVCLVNTV $_{178}$, has been found in the C-terminal part of the protein. Hence, such two sequences allow p25 to shuttle between the two compartments by the way of importin alpha and exportin 1, independantly of other viral factors (Vetter et al. 2004). Foliar symptom variations observed with p25 mutants suggest a partial correlation between p25 function and its subcellular localization (Vetter et al. 2004). If all of the p25 functions are not yet unraveled, the protein displays some common properties with transcription activators (nuclear localization, Zinc-fingerdomain, acidic domain). Indeed, in yeast, its fusion to GAL4BD or LexA allows a weak transcription activation of reporter genes (Klein et al. 2007), as it has been reported previously for NAC transcription factor (Xie et al. 2000). The domain responsible for such transcription activation has been mapped between amino acid residues 103 and 160 (Klein et al. 2007). P25 is able to form multimers as well, only if full-length proteins are maintained (Klein et al. 2007). Posttranslational modifications of p25 have been evidenced by its electrophoretic mobility (Niesbach-Klosgen et al. 1990; Klein et al. 2007) and its immunodetection after two dimensional gel eletrophoresis reveals different isoforms that mainly differ by their isoelectric point corresponding to phosphate group addition (unpublished). Aspartic acid and alanine scanning mutagenesis of predicted phosphorylation sites revealed the importance of such phosphorylation for the multimerization, nuclear import as well as the transcription activation. Only mass spectrometry analyses will permit the exact identification of such phosphorylation events on the p25 sequence. 


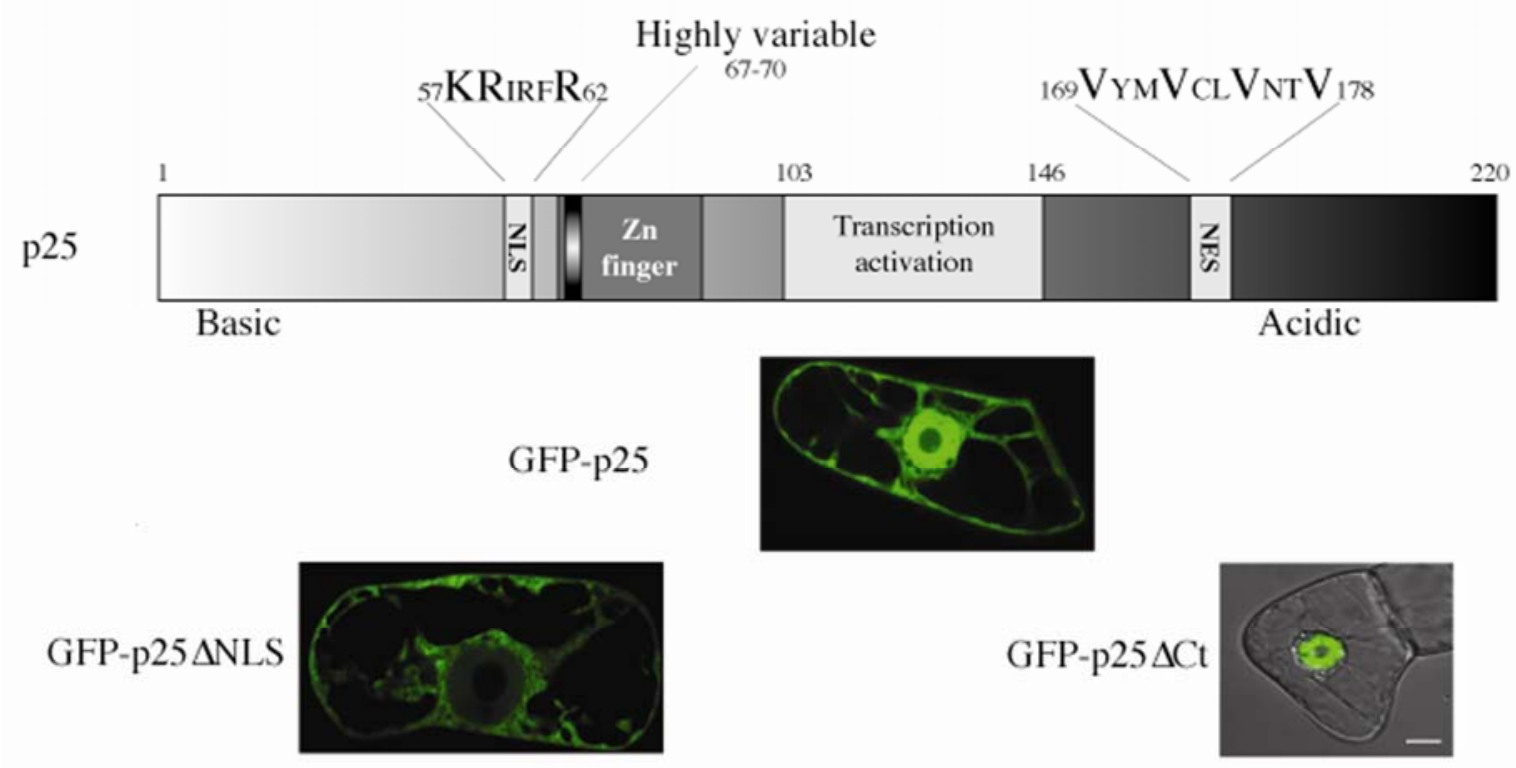

Fig. 4 Characteristics of the RNA-3-encoded p25: Line drawing representation of the p25 protein and of its known functional domains. (Top) The basic $\mathrm{N}$-terminal domain contains a nuclear localization signal (NLS, 57-62), the highly variable 'Tetrad' sequence (67-70) and a Zinc finger domain. The acidic C-terminal part of the protein encompasses a domain responsible for the transcription activation (103-146) and the nuclear export sequence (NES, 169-178). (Center) Transient expression of a GFP-p25 fusion leads to the localization of the protein in the nucleus and in the cytoplasm of the cell, whereas removal of the NLS (GFPp25 NNLS, bottom left) prevents the nuclear addressing of the fusion protein. Deletion of the C-terminal domain that contains the NES motif leads to the accumulation of the fusion protein in the nucleus (GFP-p25 $\Delta$ Ct, bottom right).

RNA-3 potentially encodes two other proteins

BNYVV RNA-3 as well as BSBMV RNA-3 encode potentially for two other proteins. The $\mathrm{N}$-gene could allow the synthesis of a $6.8 \mathrm{kDa}$ protein that has been found expressed only from RNA-3 truncated forms, fused or not with p25 ORF (Jupin et al. 1992). In such situations, expression of the protein induces severe necrosis on T. expansa and C. quinoa leaves (Jupin et al. 1992). Fused to GFP protein, p6.8 is localized to cortical reticulum even in the absence of viral infection (David Gilmer, unpublished). However, its expression has never been detected under natural conditions, leading to the hypothesis that this ORF is cryptic. The 
last ORF encodes potentially for a $4.6 \mathrm{kDa}$ polypeptide (p4.6). Such protein could be expressed from the so-called RNA-3 subgenomic species (RNA-3 sub) that corresponds to the last $550 \mathrm{nts}$ of the RNA (Balmori et al. 1993). The functions of this short RNA and its encoded peptide, if it is expressed, are still unknown.

\section{A particular function for RNA-3}

BNYVV RNA-3 has been used to map $5^{\prime}$ and $3^{\prime}$ cis acting elements required for its replication and encapsidation and for the characterization of their secondary structure in solution (Jupin et al. 1990; Gilmer et al. 1992b, 1993; Lauber et al. 1997, 1999). However, such RNA possesses another function, which seems independent of its expression. Onto B. macrocarpa, RNA-3 is absolutely required for systemic spread of the virus. The RNA-3 sequence required for such systemic movement was located between nts 1033 and 1257 (Lauber et al. 1998). Curiously, complementation of BNYVV Stras 12 strain, which contains only RNA-1 and -2, with BSBMV RNA-3 allows systemic movement of the viral particles. (Claudio Ratti and David Gilmer, unpublished). A common sequence of $20 \mathrm{nts}$ is found between both RNA species. Complementary experiments will allow deciphering the exact mechanism that permits the long distance movement.

RNA-4 is 1467 nts long and encodes for a $31 \mathrm{kDa}$ protein (p31), which is essential for the efficient transmission of the virus by $P$. betae (Tamada and Abe 1989; Rahim et al. 2007). RNA-4-encoded protein could act in synergy with the minor p75 coat protein. P31 modulate foliar symptoms, and has been recently described as a root specific silencing suppressor (Rahim et al. 2007).

RNA-5 is present only within particular isolates (see below) and is $1350 \mathrm{nts}$ long. It encodes a $26 \mathrm{kDa}$ protein (p26), which induces severe rhizomania symptoms, reducing sugar yields (Heijbroek et al. 1999). Full-length infectious cDNA clone allowed the analysis of RNA-5 expression upon viral pathogenesis and the obtention of a new viral expression vector (Link et al. 2005; Schmidlin et al. 2005). Viral expression of p26 induces severe necrosis onto C. quinoa leaves. P26 protein is localized in the nucleus and in the cytoplasm of infected cells. Moreover, when p26 is fused to GAL4DB or LexA, the fusion proteins are able to strongly activate the transcription in yeast (Link et al. 2005).

Sequence variations 
Restriction fragment length polymorphism, single-strand conformation polymorphism, sequence analyses and the presence or the absence of a fifth RNA in viral isolates permitted to classify BNYVV in different groups that are serologically identical (Kruse et al. 1994; Koenig et al. 1995). The distinction between $\mathrm{A}$ and $\mathrm{B}$-type is possible by the characterization of amino acid residues variations of the RNA-2-encoded CP in position 62, 103 and 172 (Table 1). Eight variable residues within RNA-5-encoded p26 permit the distinction between European (P-type) or Asian (J-type) RNA-5 (Table 1). European P-type RNA-5s have a shorter 5'UTR and their coding region is four codons longer than J-type RNA-5s (Table 1). Such composition and size differences do not interfere on the known properties of p26 (Link et al. 2005): both proteins induce similar foliar symptoms, localize in the nucleus and in the cytoplasm and are able to activate the transcription in yeast (Link et al. 2005) (David Gilmer, unpublished). It should be noted here that RNA-5-containing isolates could harbour an A or B-type RNA-2 (Miyanishi et al. 1999; Koenig and Lennefors 2000; Schirmer et al. 2005). A-type viruses are found in European countries, Iran, USA, China and Japan. B-type is particularly present in France, Germany, Switzerland, Sweden as well as in China and Japan (Miyanishi et al. 1999; Suarez et al. 1999; Lennefors et al. 2000; Sohi and Maleki 2004). RNA-5 containing isolates were discovered in Japan (Tamada et al. 1989; Kiguchi et al. 1996), France (Koenig et al. 1997), China (Dawei et al. 1999), Kazakhstan (Koenig and Lennefors 2000) and in England (Harju et al. 2002; Ward et al. 2007). Phylogenetic studies were performed on RNA-3 (Schirmer et al. 2005). Characterisation of RNA-3-encoded p25 sequences permitted the identification of a highly variable sequence motif between position 67 and 70 named 'tetrad' (Table 1) (Schirmer et al. 2005). Recently, new tetrad motifs have been found (Ward et al. 2007) (Audrey Schirmer, unpublished). RNA viruses endorse strong mutation rates that allow them to adapt rapidly to various situations (Domingo 2000), keeping their genetic robustness and their infectivity even in the presence of mutations (Drake and Holland 1999). Analysis of selective pressure on p25 sequences revealed that 'tetrad' sequence as well as amino acid residue 198 were submitted to high positive selection pressures (Schirmer et al. 2005) similar to those described for animal viruses bypassing mammalian immunity system (Fares et al. 2001). Such a positive selection could explain the adaptation 
of BNYVV to resistance genes (Schirmer et al. 2005) and has recently been validated for the tetrad motif (Acosta-Leal et al. 2008).

Table 1 Sequence variation within BNYVV RNA-2 encoded structural protein CP and RNA-3 and -5 encoded pathogenicity factors p25 and p26, respectively. $\Delta$, deletion; * and ${ }^{* *}$ refer to the presence of P-type or J-type respectively. (adapted from Schirmer et al. 2005)

\begin{tabular}{|c|c|c|c|c|c|c|c|c|c|c|}
\hline \multicolumn{11}{|l|}{$\mathrm{CP}^{1}$} \\
\hline \multirow[t]{2}{*}{ Position } & 62 & 10 & 172 & & & & & & & \\
\hline & & 3 & & & & & & & & \\
\hline B-type & $\mathbf{s}$ & $\mathbf{N}$ & $\mathbf{F}$ & & & & & & & \\
\hline A-type & $\mathbf{T}$ & $\mathbf{S}$ & $\mathbf{L}$ & & & & & & & \\
\hline \multicolumn{11}{|c|}{ p25 'Tetrad' ${ }^{2}$} \\
\hline Position & 67 & 68 & 69 & 70 & & & & & & \\
\hline A-type & A & C & $\mathbf{H}$ & G & & & & & & \\
\hline A-type & A & $\mathbf{F}$ & $\mathbf{H}$ & G & & & & & & \\
\hline A-type & A & $\mathbf{F}$ & $\mathbf{H}$ & $\mathbf{R}$ & & & & & & \\
\hline B-type & A & $\mathbf{H}$ & $\mathbf{H}$ & $\mathbf{R}$ & & & & & & \\
\hline A-type & A & $\mathbf{H}$ & $\mathbf{H}$ & G & & & & & & \\
\hline A-type & A & $\mathbf{L}$ & $\mathbf{H}$ & $\mathbf{G}$ & * & & & & & \\
\hline A-type & A & $Y$ & $\mathbf{F}$ & G & & & & & & \\
\hline B-type & A & $\mathbf{Y}$ & $\mathbf{H}$ & $\mathbf{R}$ & & & & & & \\
\hline A/B-type & A & $\mathbf{Y}$ & $\mathbf{H}$ & G & $* *$ & \multicolumn{5}{|c|}{ C. Bragard, unpublished } \\
\hline A-type & A & $\mathbf{Y}$ & $\mathbf{P}$ & $\mathbf{R}$ & & \multicolumn{5}{|c|}{ A. Schirmer, unpublished } \\
\hline A-type & A & $\mathbf{Y}$ & $\mathbf{R}$ & $\mathbf{v}$ & $* *$ & & & & & \\
\hline A-type & $s$ & $\mathrm{Y}$ & $\mathbf{H}$ & $\mathbf{G}$ & * & & & & & \\
\hline A-type & $T$ & $Y$ & $\mathbf{H}$ & $\mathbf{G}$ & * & \multicolumn{5}{|c|}{ (Ward et al. 2007) } \\
\hline A-type & v & C & $\mathbf{H}$ & $\mathbf{G}$ & & & & & & \\
\hline A-type & v & $\mathbf{L}$ & $\mathbf{H}$ & G & & & & & & \\
\hline \multicolumn{11}{|l|}{ p26 3} \\
\hline \multirow[t]{2}{*}{ Position } & 30 & 69 & 77 & 10 & 142 & 14 & 14 & 174 & 200 & $227-229$ \\
\hline & & & & 3 & & 6 & 9 & & & \\
\hline$P$-type & $\mathbf{N}$ & $\mathbf{L}$ & D & $\mathbf{G}$ & $\mathbf{R}$ & $\mathbf{F}$ & $\mathbf{G}$ & $S$ & A & NNN \\
\hline J-type & $\mathbf{H}$ & $\mathbf{F}$ & $?$ & D & C & $\mathbf{H}$ & $\mathbf{R}$ & $\mathbf{N}$ & $\mathbf{S}$ & $?$ \\
\hline
\end{tabular}

${ }^{1}$ Amino acid sequence variation within the coat protein that permit the distinction between A- or B-type of BNYVV. 
2 Amino acid sequence variation observed within the hypervariable Tetrad sequence of the BNYVV p25 protein. Some of those sequence variations are specific to A or B-type strains.

${ }^{3}$ Differences observed between asian (J-type) and P-type p26 proteins.

\section{PATHOGENICITY}

Root alterations occur similarly when A- or B-type viruses set the infection; however, isolates that contain RNA-5 are more aggressive, particularly onto resistant crops, accumulate at higher concentration and induce severe rhizomania symptoms (Heijbroek et al. 1999). Such a pathogenicity was retrieved onto host plants with artificial isolates (Link et al. 2005). However, the presence of RNA-5 is not sufficient to explain the increased virulence of some isolates as RB occurred in the U.S., where RNA-5 is absent (Liu et al. 2005). Molecular analyses of RB isolates revealed the presence of amino acid variation within the p25 tetrad sequence (Acosta-Leal and Rush 2007; Liu and Lewellen 2007) as well as amino acid residue 135 (Acosta-Leal and Rush 2007). Using artificial isolates that mimics such changes, virologists will be able to conclude if tetrad motif by itself is sufficient or requires another viral partner (e.g. encoded by RNA-1 or -2) to overcome $R z$ effect. Some preliminary experiments performed onto p25 revealed the importance of the tetrad motif upon the protein properties. Changing a B-type p25 tetrad sequence by one of the identified motifs drastically modifies the foliar symptoms, transcription activation and multimerization properties of p25 (Klein et al. 2007). Klein et al. suggested that p25 could behave as an avirulence gene product that could modify host responses. Chiba et al. (2008) recently demonstrated that p25 is indeed an Avr protein in B. vulgaris.

The Polymyxa betae vector

Besides BNYVV, three other viruses are also linked with rhizomania, namely the Beet soil-borne mosaic virus (BSBMV), the Beet soil-borne virus (BSBV) and the Beet virus Q (BVQ) (Meunier et al. 2003). All these viruses are transmitted to beet by the vector $P$. betae Keskin, an obligate parasite that develops in the epidermal and cortical root cells. The Polymyxa genus is represented by two economically very significant species: $P$. graminis Ledingham is specific to cereals (rice, wheat, 
barley) and $P$. betae to the Chenopodiaceae (Beta vulgaris, Spinacia oleracea, Atriplex patula, Chenopodium bonus-henricus, C. hybridum and C. polyspermum) and species like Amaranthaceae, Caryophyllaceae and Portulaceae (Abe and Tamada 1986; Barr 1988; Legrève et al. 2000, 2005). Recent molecular studies of the characterization of the ITS (internal transcribed spacers) regions of the ribosomal DNA support species separation (Legrève et al. 2002). P. betae is ubiquitous. Its distribution covers all beet-growing areas (Rush 2003). P. betae belongs to the Plasmodiophoridae, a monophyletic group including ten genera. For a long time ranked among the lower fungi, it is now classified as a protist (Archibald and Keeling 2004). The host range of $P$. betae, long considered to be narrow, now appears to be wider. $P$. betae was recently detected by RT-PCR in the roots of some species of Brassicaceae, Papaveraceae, Poaceae and Urticaceae (Anne Legrève, unpublished). Although only a low level of infection was detected in these species, it could facilitate viral recombination or help to maintain the viral load in the vector.

\section{P. betae cycle}

The viruses transmitted by Polymyxa spp. are internalised by the vector (Chen et al. 1991; Rysanek et al. 1992; Campbell 1996; Verchot-Lubicz et al. 2007). The biological cycle of the viral diseases they transmit thus depends on the vectors life cycle (Fig. 5). This vectors great capacity for survival explains, firstly, the recurrence of viral diseases in contaminated fields and, secondly, their dissemination either through the soil adhering to agricultural machinery and produce or via drainage and irrigation water. In the absence of host plant radicles, $P$. betae survives in the soil in the form of sporosores (which may be viruliferous). Sporosores are spore clusters of 5 to $7 \mu \mathrm{m}$ in diameter with a very thick, strong wall that can live for many years in the soil (Adams 1990; Maraite 1991). In the presence of host plants, resting spore germination releases biflagellated zoospores 4-5 $\mu \mathrm{m}$ in size which move through the free water in the soil before encysting on a root hair or epidermal cell of a host plant root. In order to penetrate the cell, a dagger-like structure called "Stachel (sting)" is formed in the encysted zoospore (Keskin and Fuchs 1969) and a sticky tube develops between the cyst and the plant cell wall. The Stachel, which is injected into the host cell through the 
tube, pierces the cell wall and the plasma membrane and allows the zoospore content to be transferred into the cytoplasm of the host cell (Barr 1988). Cruciform nuclear divisions indicative of mitosis lead to the formation of a multinucleate plasmodium surrounded by a thin membrane. In the sporangial phase this plasmodium develops into a multi-lobed zoosporangium enclosed by a thin wall within which the secondary zoospores are formed. The latters are released outside the root, or sometimes into the deeper root cells, by small plasmodial cells, which dissolve a hole in the cell wall (Barr 1988). In the sporogenic phase non-cruciform nuclear divisions are observed, with the formation of synaptonemal complexes characteristic of meiosis (Braselton 1988). The plasmodium divides into mononucleate cells by forming membrane layers within the cytoplasm. A four to five-layer wall is then deposited between the cells, with adjacent spores remaining connected by bonds between the two outermost layers (Chen et al. 1998). The sporosores formed remain in the root debris and are released into the soil by root decomposition. Within this life cycle the moments of cell fusion and karyogamy have not yet been pinpointed. Observation of double size quadriflagellate zoospores (Ledingham 1939) suggests fusion of two zoospores, but the moment of nuclear fusion is not known. The determinants for development of the various phases are likewise unknown (Braselton 1995). However, the host and the degree of root colonisation appear to be significant (Legrève et al. 1998). Three conditions are essential for root infection by this parasite: (1) presence of a host plant; (2) presence of free water in the soil to promote germination and facilitate zoospore access to the roots, and (3) a sufficiently high temperature between 10 and $30^{\circ} \mathrm{C}$, ideally between 20 and $25^{\circ} \mathrm{C}$ according to the origin of the strains (Legrève et al. 1998; Webb et al. 2000). Hot, wet springs are therefore propitious to early infections, as are light, sandy, well-drained soils as these heat up faster than heavy organic soils with high retention capacity (Webb et al. 2000). The soil pH and calcium content also affect vector activity. Spore germination and root infection by zoospores are affected by acid $\mathrm{pH}$ conditions (Abe and Tamada 1987). They are promoted in neutral or alkaline $\mathrm{pH}$ soils, especially if the calcium and magnesium levels are greater than 350 and $20 \mathrm{mg} / 100 \mathrm{~g}$ of soil respectively (Goffart and Maraite 1991). Managed liming and practices for regulating soil pH and calcium levels would probably result in better control of rhizomania. 


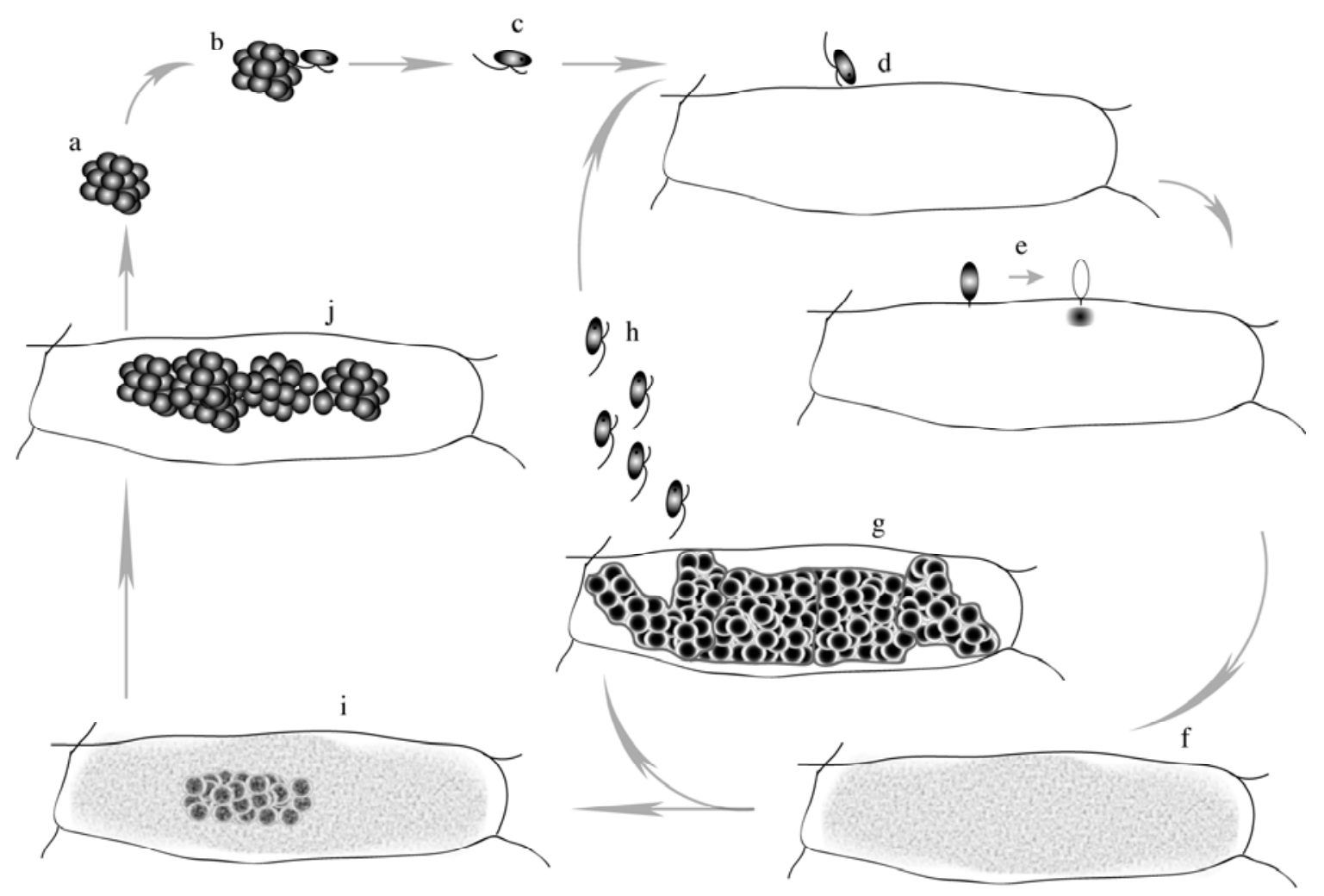

Fig. 5 Drawing of the Polymyxa spp. life cycles and its developing states. (a) sporosore; (b) germinating zoospore; (c), swimming zoospore to a (d) cortical or epidermal cell; (e) the zoospore encyst on the cell and injects its contents through the cell wall and the cellular membrane via the "satchel"; (f), developing plasmode that will tend to a zoosporangium ( $g$ ) that will issue either $(\mathrm{h})$ the secondary zoospores able to infect new cells or (i) to the sporogenous plasmod (j) leading to new sporosores. Such sporosores will be further released in soil after root decomposition

Vector detection

Plant infection by $P$. betae is not apparent from any particular symptoms. Until the early 1990s this parasite was detected in roots by observing the roots under the microscope following colouring with Lactophenol Cotton Blue. This fairly laborious method was initially used to study the vectors ecological requirements and the soil infectious potential levels by the most probable number technique, growing trap 
crops on soil dilutions (Tuitert 1990). Molecular techniques (DNA probes, PCR, nested PCR, ELISA) have greatly facilitated rapid detection of $P$. betae in roots and even in soil (Mutasa et al. 1996; Kingsnorth et al. 2003; Ward et al. 2005). Multiplex RT-PCR enables the presence of $P$. betae, BNYVV, BSBV and BVQ to be revealed in a single test using a root RNA extract (Meunier et al. 2003).

\section{Virus-vector interactions}

Modes of virus acquisition and transmission by plasmodiophorids have been described (Rochon et al. 2004). These viruses survive in the spores in a form that has not yet been clarified. However, accumulated RNA and movement proteins of Soil-borne wheat mosaic virus (SBWMV) and capsid proteins of Wheat spindle streak virus (WSSMV) within the resting spores of the vector, P. graminis, probably denote the presence of ribonucleoprotein complexes (Driskel et al. 2004). In the case of BNYVV, both the sporosores and the plasmodia of $P$. betae are labelled using antibodies against the viral capsid protein (Doucet 2006). Structural and non-structural proteins have been detected in $P$. betae spores and zoospores. These results suggest that this vector could also be a BNYVV host (VerchotLubicz et al. 2007). When transmitted by the viruliferous zoospores, the virus is present in particle form. Virus transmission by plasmodiophorids was for many years regarded as a passive mechanism, which occurred during mixing of plant cell cytoplasms and the protozoan, prior to membrane formation (Campbell 1996). However, recent research has revealed the special role played by some viral proteins in the process of transmission by the vector. The BNYVV capsid protein readthrough $(\mathrm{RT})$ domain plays an important part in the transmission process, since deletions in the C-terminal portion of this domain are correlated to loss of virus transmission. Substituting the four KTER amino acids located in position 553 to 556 of the RT domain by the ATAR motif completely blocks transmission (Tamada et al. 1996). A comparative analysis of the viral genomes transmitted by plasmodiophorids, which do not have the same genomic organisation, has identified the presence of two complementary transmembrane domains in the RT domains of the capsid protein of Beny-, Furo- and Pomovirus and in the P2 proteins of Bymovirus (Adams et al. 2001). Deletion or substitution of the second domain also blocks transmission by the vector. The molecular model is not yet 
detailed, but the transmembrane helical sequences may perhaps determine a particular structure facilitating membrane invagination and virus movement through the membrane of the vector (Adams et al. 2001). Although the molecular mechanism of the interaction is far from fully explained, the involvement of protein p31, coded by RNA-4, is strongly suspected. Two independent studies of comparative transmission of wild or mutated viruses in the coding sequence for protein p31 have in fact shown a big decrease in protein p31 mutant transmission (Rahim et al. 2007) (Anne Legrève, personal communication). In addition to its role in transmission, protein p31 is also thought to play a part both in inducing symptoms in Nicotiana benthamiana and in suppressing RNA silencing in roots, without affecting viral RNA accumulation (Rahim et al. 2007).

Genetic resistance strategies used against rhizomania disease

One of the major goals of the sugar beet industry is to stabilize the sugar yields. Due to the large area covered by rhizomania infested fields, calculated to span approx. 610,000 ha in 2000 (Richard-Molard and Carriolle 2001), a qualitative and quantitative high yielding sugar beet production is only given by growth of resistant cultivars. Since the first attempts in achieving rhizomania resistant breeding material, resistance sources were found in germplasms or wild type $B$. vulgaris ssp. maritima, which all confer phenotypes of quantitative resistance (Table 2). Involvement of additional minor genes for the expression of the rhizomania resistance trait is most likely (Biancardi et al. 2002). Nowadays, hybrid varieties (Table 2) that do not or poorly develop symptoms, display reduced virus content have replaced susceptible varieties.

The first selection of partial resistant BNYVV sugar beet genotypes started at the end of the seventies. Sugar beets characterized by reduced virus symptoms, increased white sugar content and increased processing quality were subsequently selected (de Biaggi 1987; Lewellen et al. 1987). Although these sugar beet genotypes were also infected with BNYVV, the symptoms were less pronounced and plants displayed a better performance in field trails (Bürcky 1987). In 1983, the US-American Holly Sugar Company identified the "Holly" resistance representing the first described BNYVV resistance source (Lewellen et al. 1987; Biancardi et al. 2002). 'Holly' carryies the resistance gene $R z$, which was renamed 
Rz1 (Scholten et al. 1999). Holly does not show rhizomania symptoms, but allows the virus to replicate as shown by the viral titer contents in such varieties (Scholten and Lange 2000). 'Rizor' was the first diploid hybrid partially resistant to rhizomania (Richard-Molard 1985; de Biaggi 1987). In the eighties, further resistance sources were identified in Danish tests of Beta vulgaris ssp. maritima (L.) Arcang wild-beet germplasms leading to WB41 and WB42 sources (Table 2) representing $R z 3$ and $R z 2$ resistance genes, respectively (Lewellen et al. 1987; Whitney 1989). Greenhouse tests performed applying severe infestation conditions have revealed the better performance of $R z 2$ versus $R z 1$ resistance genes suggesting a different origin of both genes (Scholten et al. 1999). However, these genes are present within Chrlll at a distance range of $20 \mathrm{cM}$ (Scholten et al. 1994, 1999) to $35 \mathrm{cM}$ (Amiri et al. 2003). Rz3 resistance gene (Table 2) has been also mapped on Chrlll at about $5 \mathrm{cM}$ from $R z 1$, suggesting that $R z 2$ and $R z 3$ might be allelic (Gidner et al. 2005). Recently, the use of the hybrid line R36 permitted the identification of a new QTL named Rz4 (Table 2), which confers partial resistance to BNYVV infection (Grimmer et al. 2007). Rz1 or Rz2 carrying cultivars reduce viral titer up to $6 \times 10^{4}$ fold when compared to susceptible lines (Acosta-Leal et al. 2008). However, their systematic use might favor genetic drift of viral population that seems to accumulate nucleotide variation twice rapidly, leading to high probability for the emergence of RB isolates (Acosta-Leal et al. 2008).

Growing of BNYVV resistant sugar beet cultivars is generally accepted as the only strategy to keep sugar beet cultivation in infested fields profitable. Reports about increased aggressiveness of BNYVV P-type (France) and appearance of new BNYVV A-types (USA: Imperial Valley, California and Minnesota) have been published (Liu et al. 2005; Liu and Lewellen 2007). These interesting studies show the viral overcome of $R z 1$ carrying cultivars in the field and measure increased BNYVV levels in hair-roots of $R z 1$ plants in greenhouse resistance tests.

Artificially generated resistance represents an alternative to the natural resistance (Table 2). The transgenic expression of virus-derived sequences that form doublestranded RNA (dsRNA) has been obtained and lead to BNYVV resistance (Lennefors et al. 2006, 2008). Expression of dsRNA induces RNA silencing (Baulcombe 2004, 2005; Filipowicz et al. 2005), an innate defense mechanism 
against invasive nucleic acids that leads to the sequence specific degradation of RNA. High levels of resistance to rhizomania were obtained in sugar beets expressing a $0.4 \mathrm{~kb}$ inverted repeat construct based on a partial BNYVV replicase gene derived sequence (Table 2) (Lennefors et al. 2006).

Transgenic sugar beets expressing the BNYVV coat protein (Scholten and Lange 2000), or a mutated form of one of the tree movement protein TGB-p3 (Lauber et al. 2001) or the sequence derived from RNA-1 (Lennefors et al. 2006, 2008) both generate higher protection levels than $R z 1$.

Table 2 Characteristics of the $R z$ resistance genes and transgenic sequences (underlined) used in sugar beet crops. All Rz genes are located on Chr. III; PDR: pathogen-derived resistance.

\begin{tabular}{|c|c|c|c|c|}
\hline $\begin{array}{l}\text { Hybrid } \\
\text { variety }\end{array}$ & Origin & $\begin{array}{l}\text { Resistance } \\
\text { gene }\end{array}$ & Nature & $\begin{array}{l}\text { Resistance } \\
\text { level }\end{array}$ \\
\hline Holly & $\begin{array}{l}\text { B. vulgaris ssp. } \\
\text { vulgaris (California) }\end{array}$ & $R z 1$ & Dominant & $\begin{array}{l}\text { Low }<\text { good } \\
\text { depending on } \\
\text { inoculum }\end{array}$ \\
\hline WB42 & $\begin{array}{l}\text { B. vulgaris ssp. } \\
\text { maritima (Denmark) }\end{array}$ & $R z 2$ & Dominant & $\mathrm{Rz} 2>\mathrm{Rz} 1$ \\
\hline WB41 & $\begin{array}{l}\text { B. vulgaris ssp } \\
\text { maritima (Denmark) }\end{array}$ & Rz3 & $\begin{array}{l}\text { Partialy } \\
\text { dominant } \\
\text { Allelic to Rz2? }\end{array}$ & Variable \\
\hline R36 & $\begin{array}{l}\text { B. vulgaris ssp. } \\
\text { maritima }\end{array}$ & $R z 4$ & $\begin{array}{l}\text { Allelic to other } \\
\text { Rz? }\end{array}$ & $\begin{array}{l}\text { Partial } \\
\text { resistance }\end{array}$ \\
\hline 4D6834 & B. vulgaris & $\begin{array}{l}\text { Movement } \\
\text { protein }\end{array}$ & PDR & Excellent \\
\hline G018 & B. vulgaris & Replicase & PDR/PTGS & Excellent \\
\hline- & B. vulgaris & $C P$ & PDR & Good \\
\hline
\end{tabular}




\section{CONCLUSIONS}

BNYVV RNA-3 and in particular the p25 protein constitutes the rhizomania disease keystones. New emerging isolates tend to bypass resistance genes by the modification of the p25 gene sequence. Sequence variations within p25 combined with the post-translational modifications make the study of this protein rather difficult. Further studies will aim to characterize the major functions of p25 protein and the cellular genes involved in the root proliferation and the parasitic infection. Thereby, such studies will be performed within and out viral context. The characterization of the p25-deregulated cellular functions should allow the identification of cellular markers that in term could help breeders for the selection of resistant crops. Before the extensive use of such new resistant varieties, prophylactic treatments are used to limit the infection. Indeed, the presence of $P$. betae in soils, crop transportation and scattering of soil by the mean of farming activities are the main factors that ensure the persistence and the spread of the virus. Even with some adapted crop rotations, the presence of highly resistant viruliferous vector spores prevents any reduction of the infection. Soil fumigation with methyl bromide reduces inoculum intensity but the Montreal protocol prevents its use as it depletes the ozone layer. Crop selection and the use of new tolerant varieties having many resistant genes (i.e. for the virus and the vector) and also the use of efficient pathogen-derived resistance may represent the most powerful alternative to grow sugar beet and maintain sugar yields.

\section{ACKNOWLEDGEMENTS}

C.P. and K.H. contributed equaly to this review. C.P was supported by SESVanderHave under a CIFRE program, K.H. was supported by a Franco-Syrian grant. The authors thank reviewers and Prof. Dr. Mark Varrelmann for their critical reading and comments. 


\section{REFERENCES}

Abe H, Tamada T (1986) Association of Beet necrotic yellow vein virus with isolates of Polymyxa betae Keskin strains in rhizomania infested soils of sugar beet in Japan. Annals of the Phytopathological Society of Japan 52, 235-247

Abe H, Tamada T (1987) A test tube culture system for multiplication of Polymyxa betae and Beet necrotic yellow vein virus in rootlets of sugar beet. In: Proceedings of the Sugar Beet Research Association, Date and location of meeting, Japan, 29, 34-38

Acosta-Leal R, Fawley MW, Rush CM (2008) Changes in the intraisolate genetic structure of Beet necrotic yellow vein virus populations associated with plant resistance breakdown. Virology 376, 60-68

Acosta-Leal R, Rush CM (2007) Mutations associated with resistance-breaking isolates of Beet necrotic yellow vein virus and their allelic discrimination using taqman technology. Phytopathology 97, 325-330

Adams MJ (1990) Epidemiology of fungally-transmitted viruses. Soil Use and Management 6, 184-189

Adams MJ, Antoniw JF, Mullins JG (2001) Plant virus transmission by plasmodiophorid fungi is associated with distinctive transmembrane regions of virus-encoded proteins. Archives of Virology 146, 1139-1153

Amiri R, Moghaddam M, Mesbah M, Sadeghian SY, Ghannadha MR, Izadpanah K (2003) The inheritance of resistance to Beet necrotic yellow vein virus (BNYVV) in B. vulgaris subsp. maritima, accession WB42: statistical comparisons with Holly-1-4. Euphytica 132, 363-373

Archibald JM, Keeling PJ (2004) Actin and ubiquitin protein sequences support a cercozoan/foraminiferan ancestry for the plasmodiophorid plant pathogens. Journal of Eukaryotic Microbiology 51, 113-118 
Balmori E, Gilmer D, Richards K, Guilley H, Jonard G (1993) Mapping the promoter for subgenomic RNA synthesis on Beet necrotic yellow vein virus RNA3. Biochemie 75, 517-521

Barr DJS (1988) Zoosporic plant parasites as fungal vectors of viruses: Taxonomy and life cycles of species involved. In: Cooper JI, Asher MJ (Eds) Developments in Applied Biology II Viruses with Fungal Vectors, Association of Applied Biologists, Wellesbourne, UK, pp 123-137

Baulcombe D (2004) RNA silencing in plants. Nature 431, 356-363

Baulcombe D (2005) RNA silencing. Trends in Biochemical Sciences 30, 290-293

Biancardi E, Lewellen RT, Biaggi MD, Erichsen AW, Stevanato P (2002) The origin of rhizomania resistance in sugar beet. Euphytica 127, 383-397

Bleykasten C, Gilmer D, Guilley H, Richards KE, Jonard G (1996). Beet necrotic yellow vein virus $42 \mathrm{kDa}$ triple gene block protein binds nucleic acid in vitro. Journal of General Virology 77, 889-897

Bouzoubaa S, Niesbach-Klosgen U, Jupin I, Guilley H, Richards K, Jonard G (1991) Shortened forms of Beet necrotic yellow vein virus RNA3 and 4: Internal deletions and a subgenomic RNA. Journal of General Virology 72, 259-266

Bouzoubaa S, Quillet L, Guilley H, Jonard G, Richards K (1987) Nucleotide sequence of Beet necrotic yellow vein virus RNA1. Journal of General Virology 68, 615-626

Braselton JP (1988) Karyology and systematics of plasmodiophoromycetes. In:Cooper JI, Asher MJ (Eds) Developments in Applied Biology II Viruses with Fungal Vectors, Association of Applied Biologists, Wellesbourne, UK, pp 139-152 
Braselton JP (1995) Current status of the plasmodiophorids. Critical Review in Microbiology 21, 263-275

Bürcky K (1987) BNYVV-Resistenz induzierende Merkmale und deren mögliche Nutzung zur Selektion Rizomaniatoleranter Zuckerrüben. In: International Institute for Beet Research (IIBR) (Ed) Proceedings of the $50^{\text {th }}$ Congress of the IIRB, 11-12 February 1987, IIRB, Brussels, pp 3-7

Campbell RN (1996) Fungal transmission of plant viruses. Annual Review of Phytopathology 34, 87-108

Canova A (1959) On the pathology of sugarbeet. Informatore Fitopatologico 9, 390-396

Chen JP, Swaby AG, Adams MJ, Ruan YL (1991) Barley mild mosaic-virus inside its fungal vector, Polymyxa graminis. Annals of Applied Biology 118, 615621

Chen JP, Wang ZQ, Hong J, Collier CR, Adams MJ (1998) Ultrastructural studies of resting spore development in Polymyxa graminis. Mycological Research 102, 687-691

Chiba S, Miyanishi M, Andika IB, Kondo H, Tamada T (2008) Identification of amino acids of the Beet necrotic yellow vein virus P25 protein required for induction of the resistance response in leaves of Beta vulgaris plants. Journal of General Virology 89, 1314-1323.

Dawei L, Jialin Y, Chenggui H, Tao L, Shucai Q, Koenig R, Yi L (1999) Detection and nucleotide analysis of RNA5 of Beet necrotic yellow vein virus isolated in China. Chineese Journal of Biotechnology 15, 253-257 
De Biaggi M (1987) Méthodes de sélection, un cas concret. In: International Institute for Beet Research (IIBR) (Ed) Proceedings of the 50th Congress of the IIRB, 11-12 Februray 1987, IIRB, Brussels, pp 157-163

Domingo E (2000) Viruses at the edge of adaptation. Virology 270, 251-253

Doucet, D. (2006). Characterization of the pecluvirus movement in plant roots (development of a model and comparison with a benyvirus). PhD thesis, Université catholique de Louvain, Louvain-la-Neuve, Belgium, 226 pp.

Drake JW, Holland J (1999) Mutation rates among RNA viruses. Proceedings of the National Academy of Sciences USA 96, 13910-13013

Driskel BA, Doss P, Littlefield LJ, Walker NR, Verchot-Lubicz J (2004) Soilborne wheat mosaic virus movement protein and RNA and wheat spindle streak mosaic virus coat protein accumulate inside resting spores of their vector, Polymyxa graminis. Molecular Plant-Microbe Interactions 17, 739-748

Dunoyer P, Pfeffer S, Fritsch C, Hemmer O, Voinnet O, Richards KE (2002) Identification, subcellular localization and some properties of a cysteine-rich suppressor of gene silencing encoded by Peanut clump virus. The Plant Journal 29, 555-567

Erhardt M, Dunoyer P, Guilley H, Richards K, Jonard G, Bouzoubaa S (2001) Beet necrotic yellow vein virus particles localize to mitochondria during infection. Virology 286, 256-262

Erhardt M, Morant M, Ritzenthaler C, Stussi-Garaud C, Guilley H, Richards K, Jonard G, Bouzoubaa S, Gilmer D (2000) P42 movement protein of Beet necrotic yellow vein virus is targeted by the movement proteins $\mathrm{P} 13$ and $\mathrm{P} 15$ to punctate bodies associated with plasmodesmata. Molecular Plant-Microbe Interactions 13, 520-528 
Erhardt M, Vetter G, Gilmer D, Bouzoubaa S, Richards K, Jonard G, Guilley H (2005) Subcellular localization of the triple gene block movement proteins of Beet necrotic yellow vein virus by electron microscopy. Virology 340, 155-166

Fares MA, Moya A, Escarmis C, Baranowski E, Domingo E, Barrio E (2001) Evidence for positive selection in the capsid protein-coding region of the Foot-andmouth disease virus (FMDV) subjected to experimental passage regimens. Molecular Biology and Evolution 18, 10-21

Fauquet CM, Mayo MA, Maniloff J, Desselberger U, Ball LA (2005). In Virus Taxonomy: VIIIth report of the ICTV. (London: Elsevier/Academic Press)

Filipowicz W, Jaskiewicz L, Kolb FA, Pillai RS (2005) Post-transcriptional gene silencing by siRNAs and miRNAs. Current Opinion in Structural Biology 15, 331341

Gidner S, Lennefors BL, Nilsson NO, Bensefelt J, Johansson E, Gyllenspetz U, Kraft T (2005) QTL mapping of BNYVV resistance from the WB41 source in sugar beet. Genome 48, 279-285

Gilmer D, Allmang C, Ehresmann C, Guilley H, Richards K, Jonard G, Ehresmann B (1993) The secondary structure of the 5'-noncoding region of Beet necrotic yellow vein virus RNA3: Evidence for a role in viral RNA replication. Nucleic Acids Research 21, 1389-1395

Gilmer D, Bouzoubaa S, Hehn A, Guilley H, Richards K, Jonard G (1992a) Efficient cell-to-cell movement of Beet necrotic yellow vein virus requires 3' proximal genes located on RNA2. Virology 189, 40-47

Gilmer D, Richards K, Jonard G, Guilley H (1992b) Cis-active sequences near the 5'-termini of Beet necrotic yellow vein virus RNAs 3 and 4 . Virology 190, 55-67 
Goffart JP, Maraite H (1991) Soil and agronomic factors affecting the inoculums potential of Polymyxa betae keskin in Belgium. Parasitica 47, 165-192

Grimmer M, Trybush S, Hanley S, Francis S, Karp A, Asher M (2007) An anchored linkage map for sugar beet based on AFLP, SNP and RAPD markers and QTL mapping of a new source of resistance to Beet necrotic yellow vein virus. Theoretical and Applied Genetics 114, 1151-1160

Haeberle AM, Stussi-Garaud C (1995) In situ localization of the non-structural protein P25 encoded by Beet necrotic yellow vein virus RNA3. Journal of General Virology 76, 643-650

Haeberle AM, Stussi-Garaud C, Schmitt C, Garaud JC, Richards KE, Guilley H, Jonard G (1994) Detection by immunogold labelling of P75 readthrough protein near an extremity of Beet necrotic yellow vein virus particles. Archives of Virology 134, 195-203

Harju VA, Mumford RA, Bockley A, Boonham N, Clover GRG, Weekes R, Henry CM (2002) Occurence in the united kingdom of Beet necrotic yellow vein virus isolates which contain RNA5. Plant Pathology 51, 811

Hehn A, Bouzoubaa S, Bate N, Twell D, Marbach J, Richards K, Guilley H, Jonard G (1995) The small cysteine-rich protein P14 of Beet necrotic yellow vein virus regulates accumulation of RNA2 in cis and coat protein in trans. Virology 210, 73-81

Hehn A, Fritsch C, Richards KE, Guilley H, Jonard G (1997) Evidence for in vitro and in vivo autocatalytic processing of the primary translation product of beet necrotic yellow vein virus RNA1 by a papain-like proteinase. Archives of Virology 142, 1051-1058 
Heijbroek W, Musters PMS, Schoone AHL (1999) Variation in pathogenicity and multiplication of Beet necrotic yellow vein virus (BNYVV) in relation to the resistance of sugarbeet cultivars. European Journal of Plant Pathology 105, 397405

Jupin I, Guilley H, Richards KE, Jonard G (1992) Two proteins encoded by Beet necrotic yellow vein virus RNA3 influence symptom phenotype on leaves. The EMBO Journal 11, 479-488

Jupin I, Richards K, Jonard G, Guilley H, Pleij CW (1990) Mapping sequences required for productive replication of Beet necrotic yellow vein virus RNA3. Virology 178, 273-280

Keskin B (1964) Polymyxa betae n.Sp., a parasite in the roots of Beta vulgaris tournefort, particularly during the early growth of the sugar beet. Archiv für Mikrobiologie 19, 348-374

Keskin B, Fuchs WH (1969) The process of infection by Polymyxa betae. Archiv für Mikrobiologie 68, 218-226

Kiguchi T, Saito M, Tamada T (1996) Nucleotide sequence analysis of RNA5 of five isolates of Beet necrotic yellow vein virus and the identity of a deletion mutant. Journal of General Virology 77, 575-580

Kingsnorth CS, Asher MJC, Keane GJP, Chwarszczynska DM, Luterbacher MC, Mutasa-Gottgens ES (2003) Development of a recombinant antibody ELISA test for the detection of Polymyxa betae and its use in resistance screening. Plant Pathology 52, 673-680

Klein E, Link D, Schirmer A, Erhardt M, Gilmer D (2007) Sequence variation within Beet necrotic yellow vein virus P25 protein influences its oligomerization and isolate pathogenicity on Tetragonia expansa. Virus Research 126, 53-61 
Koenig R, Haeberle AM, Commandeur U (1997) Detection and characterization of a distinct type of Beet necrotic yellow vein virus RNA5 in a sugarbeet growing area in Europe. Archives of Virology 142, 1499-1504

Koenig R, Jarausch W, Li Y, Commandeur U, Burgermeister W, Gehrke M, Luddecke P (1991) Effect of recombinant Beet necrotic yellow vein virus with different RNA compositions on mechanically inoculated sugarbeets. Journal of General Virology 72, 2243-2246

Koenig R, Lennefors BL (2000) Molecular analyses of european A, B and P type sources of Beet necrotic yellow vein virus and detection of the rare $P$ type in Kazakhstan. Archives of Virology 145, 1561-1570

Koenig R, Luddecke P, Haeberle AM (1995) Detection of Beet necrotic yellow vein virus strains, variants and mixed infections by examining singlestrand conformation polymorphisms of immunocapture RT-PCR products. Journal of General Virology 76, 2051-2055

Kruse M, Koenig R, Hoffmann A, Kaufmann A, Commandeur U, Solovyev AG, Savenkov I, Burgermeister W (1994) Restriction fragment length polymorphism analysis of reverse transcription-PCR products reveals the existence of two major strain groups of Beet necrotic yellow vein virus. Journal of General Virology 75, 1835-1842

Lauber E, Guilley H, Richards K, Jonard G, Gilmer D (1997) Conformation of the 3'-end of beet necrotic yellow vein Benyvirus RNA3 analysed by chemical and enzymatic probing and mutagenesis. Nucleic Acids Research 25, 4723-4729

Lauber E, Guilley H, Tamada T, Richards KE, Jonard G (1998) Vascular movement of Beet necrotic yellow vein virus in Beta macrocarpa is probably dependent on an RNA3 sequence domain rather than a gene product. Journal of General Virology 79, 385-393 
Lauber E, Janssens L, Weyens G, Jonard G, Richards KE, Lefebvre M, Guilley H (2001) Rapid screening for dominant negative mutations in the Beet necrotic yellow vein virus triple gene block proteins $\mathrm{P} 13$ and P15 using a viral replicon. Transgenic Research 10, 293-302

Lauber E, Jonard G, Guilley H, Gilmer D (1999) Effects of structural modifications upon the accumulation in planta of replicons derived from Beet necrotic yellow vein virus RNA3. Archives of Virology 144, 1201-1208

Ledingham GA (1939) Studies of Polymyxa graminis, n. Gen. N. Sp., a plasmodiophoraceous root parasite of wheat. Canadian Journal of Research 17, $38-51$

Lee L, Telford EB, Batten JS, Scholthof KB, Rush CM (2001) Complete nucleotide sequence and genome organization of Beet soilborne mosaic virus, a proposed member of the genus Benyvirus. Archives of Virology 146, 2443-2453

Legrève A, Delfosse P, Maraite H (2002) Phylogenetic analysis of Polymyxa species based on nuclear $5.8 \mathrm{~s}$ and internal transcribed spacers ribosomal DNA sequences. Mycological Research 106, 138-147

Legrève A, Delfosse P, Vanpee B, Goffin A, Maraite H (1998) Differences in temperature requirements between Polymyxa sp. of Indian origin and Polymyxa graminis and Polymyxa betae from temperate areas. European Journal of Plant Pathology 104, 195-205

Legrève A, Schmit JF, Bragard C, Maraite H (2005) The role of climate and alternative hosts in the epidemiology of rhizomania. In: Rush CM (Ed) International Working Group on Plant Viruses with Fungal Vectors, 5-7 September 2005, American Society of Sugar Beet Technologists, Bologna, Italy, pp 125-128 
Legrève A, Vanpee B, Delfosse P, Maraite H (2000) Host range of tropical and sub-tropical isolates of Polymyxa graminis. European Journal of Plant Pathology 106, 379-389

Lennefors BL, Lindsten K, Koenig R (2000) First record of A and B type Beet necrotic yellow vein virus in sugar beets in Sweden. European Journal of Plant Pathology 106, 199-201

Lennefors BL, Savenkov EI, Bensefelt J, Wremerth-Weich E, Roggen P, Tuvesson S, Valkonen JP, Gielen J (2006) DsRNA-mediated resistance to beet necrotic yellow vein virus infections in sugar beet (Beta vulgaris L. ssp. vulgaris). Molecular Breeding 18, 313-325

Lennefors BL, van Roggen PM, Yndgaard F, Savenkov EI, Valkonen JP (2008) Efficient dsRNA-mediated transgenic resistance to Beet necrotic yellow vein virus in sugar beets is not affected by other soilborne and aphidtransmitted viruses. Transgenic Research 17, 219-228

Lewellen RT, Skoyen IO, Erichsen AW (1987) Breeding sugar beet for resistance to rhizomania: Evaluation of host-plant reactions and selection for and inheritance. In: International Institute for Beet Research (IIBR) (Ed) Proceedings of the 50th Congress of the IIRB, 11-12 February 1987, IIRB, Brussels, pp 139-156

Link D, Schmidlin L, Schirmer A, Klein E, Erhardt M, Geldreich A, Lemaire, Gilmer D (2005) Functional characterization of the Beet necrotic yellow vein virus RNA5 encoded P26 protein: Evidence for structural pathogenicity determinants. Journal of General Virology 86, 2115-2125

Liu H-Y, Lewellen RT (2007) Distribution and molecular characterization of resistance-breaking isolates of Beet necrotic yellow vein virus in the United States. Plant Disease 91, 847-851 
Liu HY, Sears JL, Lewellen RT (2005) Occurence of resistance-breaking Beet necrotic yellow vein virus of sugar beet. Plant Disease 89, 464-468

Maraite H (1991) Transmission of viruses by soil fungi. In: Beemster ABR, Bollen GH, Gerlagh M, Ryuissen MA, Schipers B, Tempels A (Eds) Developments in Agricultural and Managed-Forest Ecology: Biotic Interactions and Soil-Borne Diseases, Elsevier Science Publishers, Amsterdam, NL, pp 67-82

Meunier A, Schmit JF, Stas A, Kutluk N, Bragard C (2003) Multiplex reverse transcription-PCR for simultaneous detection of Beet necrotic yellow vein virus, Beet soilborne virus, and Beet virus $Q$ and their vector Polymyxa betae Keskin on sugar beet. Applied and Environmental Microbiology 69, 2356-2360

Miyanishi M, Kusume T, Saito M, Tamada T (1999) Evidence for three groups of sequence variants of Beet necrotic yellow vein virus RNA5. Archives of Virology $144,879-892$

Morozov SY, Solovyev AG (2003) Triple gene block: Modular design of a multifunctional machine for plant virus movement. Journal of General Virology 84, $1351-1366$

Morales FJ, Ward E, Castaño M, Arroyave JA, Lozano I, Adams MJ (1999). Emergence and partial characterization of Rice stripe necrosis virus and its fungus vector in South America. European Journal of Plant Pathology 105, 643-650

Mutasa ES, Chwarszczynska DM, Asher MJ (1996) Single-tube, nested PCR for the diagnosis of Polymyxa betae infection in sugar beet roots and colorimetric analysis of amplified products. Phytopathology 86, 493-497

Niesbach-Klosgen U, Guilley H, Jonard G, Richards K (1990) Immunodetection in vivo of Beet necrotic yellow vein virus encoded proteins. Virology 178, 52-61 
Pollini CP, Giunchedi L (1989) Comparative histopathology of sugar beets that are susceptible and partially resistant to rhizomania. Phytopathologia Mediterranea 28, 16-21

Pollini CP, Masia A, Giunchedi L (1990) Free indole-3-acetic acid in sugarbeet root of rhizomania-susceptible and moderately resistant cultivars. Phytopathologia Mediterranea 29, 191-195

Putz C (1977) Composition and structure of Beet necrotic yellow vein virus. Journal of General Virology 35, 397-401

Quillet L, Guilley H, Jonard G, Richards K (1989) In vitro synthesis of biologically active Beet necrotic yellow vein virus RNA. Virology 172, 293-301

Rahim MD, Andika IB, Han C, Kondo H, Tamada T (2007) RNA4 encoded P31 of Beet necrotic yellow vein virus is involved in efficient vector transmission, symptom severity and silencing suppression in roots. Journal of General Virology 88, $1611-1619$

Richard-Molard M (1985) Rhizomania: A world-wide danger to sugar beet. Span 28, 92-94

Richard-Molard M, Carriolle M (2001) Biotic and abiotic stress and genetic improvement in France. In: International Institute for Beet Research (IIBR) (Ed) Proceedings of the 64th Congress of the IIRB, 26-27 June 2001, IIRB, Brussels, pp 153-158

Rochon D-A, Kakani K, Robbins M, Reade R (2004) Molecular aspects of plant virus transmission by olpidium and plasmodiophorid vectors. Annual Review of Phytopathology 42, 211-241

Rush CM (2003) Ecology and epidemiology of Benyviruses and plasmodiophorid vectors. Annual Review of Phytopathology 41, 567-592 
Rysanek P, Stocky G, Haeberle AM, Putz C (1992) Immunogold labelling of Beet necrotic yellow vein virus particles inside its fungal vector, Polymyxa betae K. Agronomie 12, 651-659

Schirmer A, Link D, Cognat V, Moury B, Beuve M, Meunier A, Bragard C, Gilmer D, Lemaire O (2005) Phylogenetic analysis of isolates of Beet necrotic yellow vein virus collected worldwide. Journal of General Virology 86, 2897-2911

Schmidlin L, De Bruyne E, Weyens G, Lefebvre M, Gilmer D (2008). Identification of differentially expressed root genes upon rhizomania disease. Molecular Plant Pathology 9, 741-751.

Schmidlin L, Link D, Mutterer J, Guilley H, Gilmer D (2005) Use of a Beet necrotic yellow vein virus RNA5 derived replicon as a new tool for gene expression. Journal of General Virology 86, 463-467

Schmitt C, Balmori E, Jonard G, Richards KE, Guilley H (1992) In vitro mutagenesis of biologically active transcripts of Beet necrotic yellow vein virus RNA2: Evidence that a domain of the $75-\mathrm{kDa}$ readthrough protein is important for efficient virus assembly. Proceedings of the National Academy of Sciences USA 89, 5715-5719

Scholten OE, Bock TSMD, Klein-Lankhorst RM, Lange W (1999) Inheritance of resistance to Beet necrotic yellow vein virus in Beta vulgaris conferred by a second gene for resistance. Theoretical and Applied Genetics 99, 740-746

Scholten OE, Lange W (2000) Breeding for resistance to rhizomania in sugar beet: A review. Euphytica 112, 219-231

Scholten OE, Paul H, Peters D, Van Lent JW, Goldbach RW (1994) In situ localisation of Beet necrotic yellow vein virus (BNYVV) in rootlets of susceptible and resistant beet plants. Archives of Virology 136, 349-361 
Sohi H, Maleki M (2004) Evidence for presence of types A and B of Beet necrotic yellow vein virus (BNYVV) in Iran. Virus Genes 29, 353-358

Steven A, Trus B, Putz C, Wurtz M (1981) The molecular organization of Beet necrotic yellow vein virus. Virology $113,428-438$

Suarez MB, Grondona I, Garcia-Benavides P, Monte E, Garcia-Acha I (1999) Characterization of Beet necrotic yellow vein Furovirus from Spanish sugar beets. International Microbiology 2, 87-92

Tamada T (1999) Benyviruses. In: Webster R, Granoff A (Eds) Encyclopedia of Virology (2nd Edn), Academic Press, New York, N.Y., pp 154-160

Tamada T, Abe H (1989) Evidence that Beet necrotic yellow vein virus RNA4 is essential for transmission by the fungus Polymyxa betae. Journal of General Virology 70, 3391-3398

Tamada T, Baba T (1973) Beet necrotic yellow vein virus from rhizomaniaaffected sugar beet in Japan. Annals of the Phytopathological Society of Japan, 325-332

Tamada T, Schmitt C, Saito M, Guilley H, Richards K, Jonard G (1996) High resolution analysis of the readthrough domain of Beet necrotic yellow vein virus readthrough protein: A KTER motif is important for efficient transmission of the virus by Polymyxa betae. Journal of General Virology 77, 1359-1367

Tamada T, Shirako Y, Abe H, Saito M, Kigushi T, Harada T (1989) Production and pathogenicity of isolates of Beet necrotic yellow vein virus with different numbers of RNA components. Journal of General Virology 70, 3399-3409

Tamada T, Uchino H, Kusume T, Saito M (1999) RNA3 deletion mutants of Beet necrotic yellow vein virus do not cause rhizomania disease in sugar beets. Phytopathology 89, 1000-1006 
Tuitert G (1990) Assessment of the inoculum potential of Polymyxa betae and Beet necrotic yellow vein virus (BNYVV) in soil using the most probable number method. Netherlands Journal of Plant Pathology 96, 331-341

Valentin C, Dunoyer P, Vetter G, Schalk C, Dietrich A, Bouzoubaa S (2005) Molecular basis for mitochondrial localization of viral particles during Beet necrotic yellow vein virus infection. Journal of Virology 79, 9991-10002

Van Regenmortel MH, Fauquet CM, Bishop DHL, Carstens EB, Estes MK, Lemon SM, Maniloff J, Mayo MA, McGeoch DJ, Pringle CR, Wickner RB (Eds.) (2000) Virus taxonomy: Seventh report of the international committee on taxonomy of viruses (NewYork: Academic Press)

Verchot-Lubicz J, Rush C, Payton M, Colberg T (2007) Beet necrotic yellow vein virus accumulates inside resting spores and zoosporangia of its vector Polymyxa betae BNYVV infects $P$. betae. Virology Journal 4, 37

Vetter G, Hily JM, Klein E, Schmidlin L, Haas M, Merkle T, Gilmer D (2004) Nucleo-cytoplasmic shuttling of the beet necrotic yellow vein virus RNA3-encoded P25 protein. Journal of General Virology 85, 2459-2469

Ward E, Kanyuka K, Motteram J, Kornyukhin D, Adams MJ (2005) The use of conventional and quantitative real-time PCR assays for Polymyxa graminis to examine host plant resistance, inoculum levels and intraspecific variation. New Phytologist 165, 875-885

Ward L, Koenig R, Budge G, Garrido C, McGrath C, Stubbley H, Boonham N (2007) Occurrence of two different types of RNA5 containing Beet necrotic yellow vein virus in the UK. Archives of Virology 152, 59-73

Webb CR, Gilligan CA, Asher MJC (2000) Modelling the effect of temperature on the development of Polymyxa betae. Plant Pathology 49, 600-607 
Weiland JJ, Van Winckle D, Edwards MC, Larson RL, Shelver WL, Freeman TP, Liu H-Y (2007) Characterization of a US isolate of Beet black scorch virus. Phytopathology 97, 1245-1254

Whitney ED (1989) Identification, distribution, and testing for resistance to rhizomania in Beta maritima. Plant Disease 73, 287-290

Wisler GC, Lewellen RT, Sears JL, Wasson JW, Liu HY, Wintermantel WM (2003) Interactions between Beet necrotic yellow vein virus and Beet soilborne mosaic virus in sugar beet. Plant Disease 87, 1170-1175

Xie Q, Frugis G, Colgan D, Chua NH (2000) Arabidopsis NAC1 transduces auxin signal downstream of TIR1 to promote lateral root development. Genes and Development 14, 3024-3036 


\title{
Kapitel 3: Identification of beet necrotic yellow vein virus P25 pathogenicity factor interacting sugar beet proteins which represent putative virus targets or components of plant resistance
}

Manuscript in press - Molecular Plant Microbe Interactions

\section{Heike Thiel and Mark Varrelmann}

\section{Address}

Department of Crop Sciences, Section Plant Virology, University of Göttingen, Grisebachstrasse 6, D-37077 Göttingen, Germany

Corresponding author

Mark Varrelmann, e-mail: varrelmann@ifz-goettingen.de

\begin{abstract}
Beet necrotic yellow vein virus induces the most important disease threatening sugar beet. The growth of partially resistant hybrids carrying monogenic dominant resistance genes stabilize yield but are unable to entirely prevent virus infection and replication. P25 is responsible for symptom development and previous studies have shown that recently occurring resistance breaking isolates possess increased P25 variability. To understand the viral pathogenicity factor's interplay with plant proteins better and to possibly unravel the molecular basis of sugar beet antivirus resistance, P25 was applied in a yeast two-hybrid screen of a resistant sugar beet cDNA library. This screen identified candidate proteins recognized as orthologues from other plant species which are known to be expressed following pathogen infection and involved in plant defense response. Most of the candidates potentialy related to host-pathogen interactions were involved in the ubiquitylation process, plants response to stress as well as part of cell and metabolism
\end{abstract}


components. The interaction of several candidate genes with P25 was confirmed in Nicotiana benthamiana leaf cells by transient agrobacterium-mediated expression applying bimolecular fluorescence complementation assay. The putative functions of several of the candidates identified support previous findings and present first targets for understanding the BNYVV pathogenicity and antivirus resistance mechanism.

Additional keywords: rhizomania, benyvirus, Beta vulgaris

\section{INTRODUCTION}

Beet necrotic yellow vein virus (BNYVV) (Tamada and Baba, 1973) is the type species of the genus Benyvirus accepted by International Committee on Taxonomy of Viruses (ICTV) in 1997 (Tamada, 1999). BNYVV, transmitted by the soil-borne plasmodiophoromycete Polymyxa betae (Adams et al., 2001; Dessens and Meyer 1996; Keskin 1964; Rush 2003), is the causal agent of rhizomania. Rhizomania is the sugar beet disease with the greatest economic significance because it possesses the ability to severely reduce plant (up to 90\%) and sugar yield (up to $70 \%$ ) in susceptible cultivars (Johansson, 1985; Richard-Molard, 1985; Tamada, 1999). For details about the worldwide distribution of rhizomania infested areas, see Gidner et al. 2005; Richard-Molard and Cariolle 2001.

BNYVV damages sugar beet by the symptoms it induces. BNYVV causes susceptible sugar beets to develop an extensive proliferation of additionally formed but necrotic root hairs which form a root beard. The tap root often reveals a stunted wine glass shape with brownish vasculature. When leaves are invaded, which rarely occurs, leaf veins become yellow and eventually necrotic (Koenig 2008). Little is known about the molecular mechanisms and the virus induced physiological alterations which form these symptoms. Pollini and Giunchedi (1989) have described the virus induced histological changes of BNYVV infested sugar beet root hairs and (Pollini et al. 1990) reported an increase of free auxin exclusively in susceptible infested sugar beet root hairs. Molecular data, supplying an insight into the differential expression of sugar beet root genes following 
BNYVV infection, were recently generated by Schmidlin and co-workers (2008). Their extensive differential transcriptomic analysis revealed virus and host plant specific expression of candidate genes linked to cell cycle, ubiquitin/proteasome system (UPS), general metabolism, defense signaling and oxidative stress response. Larson et al. (2008) analyzed proteome changes evaluated with multidimensional liquid chromatography from different sugar beet accessions induced by BNYVV. Results suggested involvement of systemic resistance elements and the role of phytohormones needed for symptom development. The BNYVV genome organization and detailed known functions of virus encoded proteins are summarized in (Koenig 2008). In general the BNYVV multicomponent genome consists of four, in some isolates five, positive single-stranded RNAs. RNA1 and RNA2 contain all the house-keeping genes, necessary for replication, encapsidation, suppression of RNA silencing and virus movement. RNA4 is involved in vector-mediated transmission and root specific suppression of RNA silencing (Rahim et al. 2007). RNA3 encoded P25 protein is responsible for rhizomania symptom development in sugar beet and the formation of severe symptoms in leaves of mechanically inoculated sugar beets and Chenopodium quinoa (Chiba et al. 2008; Klein et al. 2007; Koenig et al. 1991; Tamada et al. 1989; Tamada 1999; Tamada 2007). RNA5 (present mainly in Asia and in limited geographic regions in France and UK) encodes another pathogenicity factor P26 involved in symptom expression (Koenig et al. 1997; Link et al. 2005; Miyanishi et al. 1999; Schirmer et al. 2005; Schmidlin et al. 2005; Ward et al. 2007), which may act synergistically with RNA3 encoded P25 (Tamada et al. 1996a).

Due to the severe damage induced by the virus and lack of viable alternative control measures between virus and sugar beet production is entirely dependant on resistant cultivars to control the disease. Lewellen et al. (1987) reported the identification of partial resistant germplasm in field trials of the Holly Sugar Company. Currently the "Holly" source still contains the most important major dominant resistance gene named $R z 1$ (reviewed by Biancardi et al. 2002; Scholten and Lange 2000). Additionally, wild beet (B. vulgaris ssp. maritima) accessions served as sources for further major resistance genes (Rz2 - Rz4) (Gidner et al. 2005; Grimmer et al. 2007; Scholten et al. 1994; Scholten et al. 1999; Whitney 1989). The resistance mechanism remains largely unknown, Rz1, 
$R z 2$ and $R z 3$ plus a combination of the genetic background and additional minor genes, possess the ability to reduce the virus replication and content in hairy roots and restrict virus spread to the tap root (Heijbroek et al. 1999; Luterbacher et al. 2005; Scholten et al. 1994; Tamada et al. 1996b). However, alone or in combination, all known major resistance genes provide only quantitative resistance and do not seem to entirely prevent BNYVV replication and cell-to-cell movement from the initial vector infected cells in sugar beet root cells.

Several recent publications provided indirect evidence that P25 might be the target of recognition of the sugar beet antivirus resistance. Even though the different pathotypes A, B and P of BNYVV possess highly conserved RNA1 and RNA2 components, several studies reported a high variability in the P25 pathogenicity factor amino acid tetrad 67-70, especially in A-type isolates (Chiba et al. 2003; Koenig and Lesemann 2005; Schirmer et al. 2005; Tamada et al. 2003; Ward et al. 2007; Yilmaz et al. 2007). Moreover this tetrad composition determines lesion type reflecting resistance response in mechanically inoculated $B$. vulgaris "Rizor" and B. maritima leaves, suggesting that P25 functions as an avirulence (Avr) gene product (Chiba et al. 2008; Tamada 2007). In addition, Klein et al. 2007 supplied other evidence for the role of P25 aa 67-70 tetrad in BNYVV symptom severity in leaves of the host Tetragonia expansa. BNYVV P25 represents a nuclear shuttling protein, containing nuclear localization (NLS) and nuclear export (NES) signals (Vetter et al. 2004). Klein et al. (2007) additionally found evidence for P25 oligomerization and an influence of the tetrad composition on this ability.

Recently, BNYVV isolates capable of overcoming Rz1 resistance in the field have been reported from several independent field locations in the USA and Europe (Liu et al. 2005; Liu and Lewellen 2007; Pferdmenges et al. 2008), indicating that the durability of rhizomania resistance in sugar beet seems to be threatened through the large scale cultivation of a single resistance source (Rz1) (Acosta-Leal et al. 2008).

The objectives of this study were to detect BNYVV cellular targets and to identify resistance factors involved in the recognition of P25 in an incompatible Rz2-based interaction. Both interrelations are probably based on physical protein-protein interactions and their identification and functional analysis of the partners might result in a first understanding of the molecular and cellular mechanisms of this 
plant-virus interplay. To achieve this yeast two-hybrid (YTH) has proven itself invaluable as a sensitive molecular genetic approach in the mapping of proteinprotein interactions in vivo. We have screened for P25 interacting sugar beet proteins by applying a cDNA library from a homozygous $R z 2$ carrying sugar beet line. Many candidate proteins were identified, displaying no detectable transcriptional autoactivation and physical interaction of variable intensity in yeast cells. Subsequent in planta analysis in $N$. benthamiana leaf cells resulted in proof of expression and interaction, applying a BiFC system based on Agrobacterium tumefaciens transient expression.

\section{RESULTS}

Identification of sugar beet Rz2 candidate proteins interacting with BNYVV B-type P25 in yeast cells following a LexA YTH cDNA library screen.

P25 sugar beet proteome interaction of an incompatible host-pathogen interaction (BNYVV B-type versus $R z 2$ sugar beet genotype) was studied in a LexA based YTH system. A cDNA library from a BNYVV B-type infected $R z 2$ harboring sugar beet breeding line, consisting of $1.4 \times 10^{6}$ independent clones, wasf chosen. 420 green fluorescing colonies were picked out of approximately $1 \times 10^{6}$ transformed yeast colonies and used for further characterization. De-selection of transcriptional autoactivators, re-transformation and repetition of the interaction assay resulted in a total number of 36 P25 interacting candidates (Fig. 1) with an insert size varying from approximately $300 \mathrm{bp}$ to $1200 \mathrm{bp}$ (Table 1 ) remained. The strength of the P25-cDNA encoded candidate interactions was monitored indirectly by quantification of the Leu-driven GFP expression. As shown in Figure 1B, GFP expression was detectable in all different cDNA library candidate P25 interaction tests; significant differences in strength of the interaction were observed. 
A

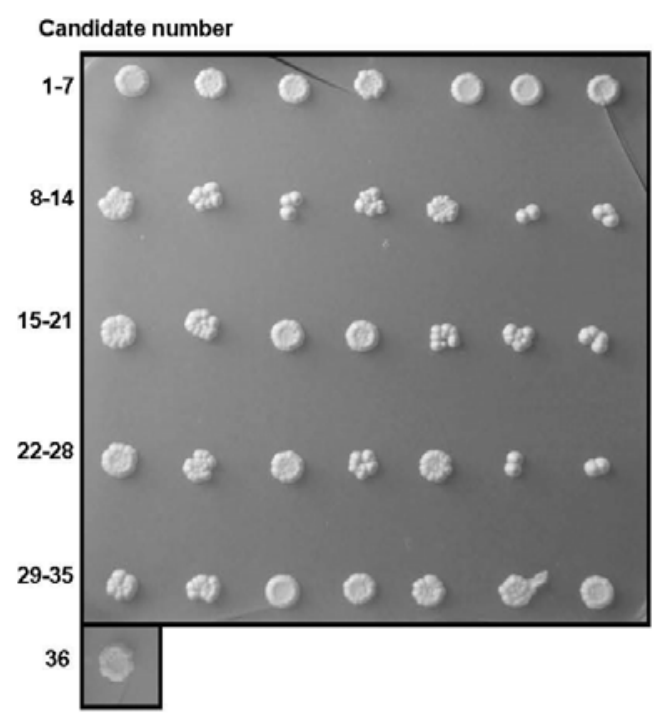

B

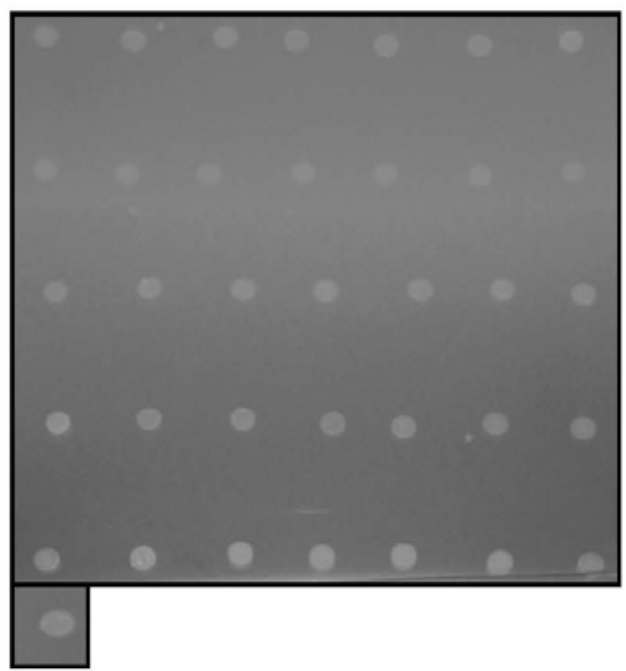

C

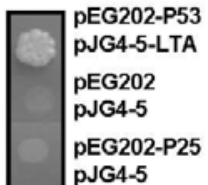

D

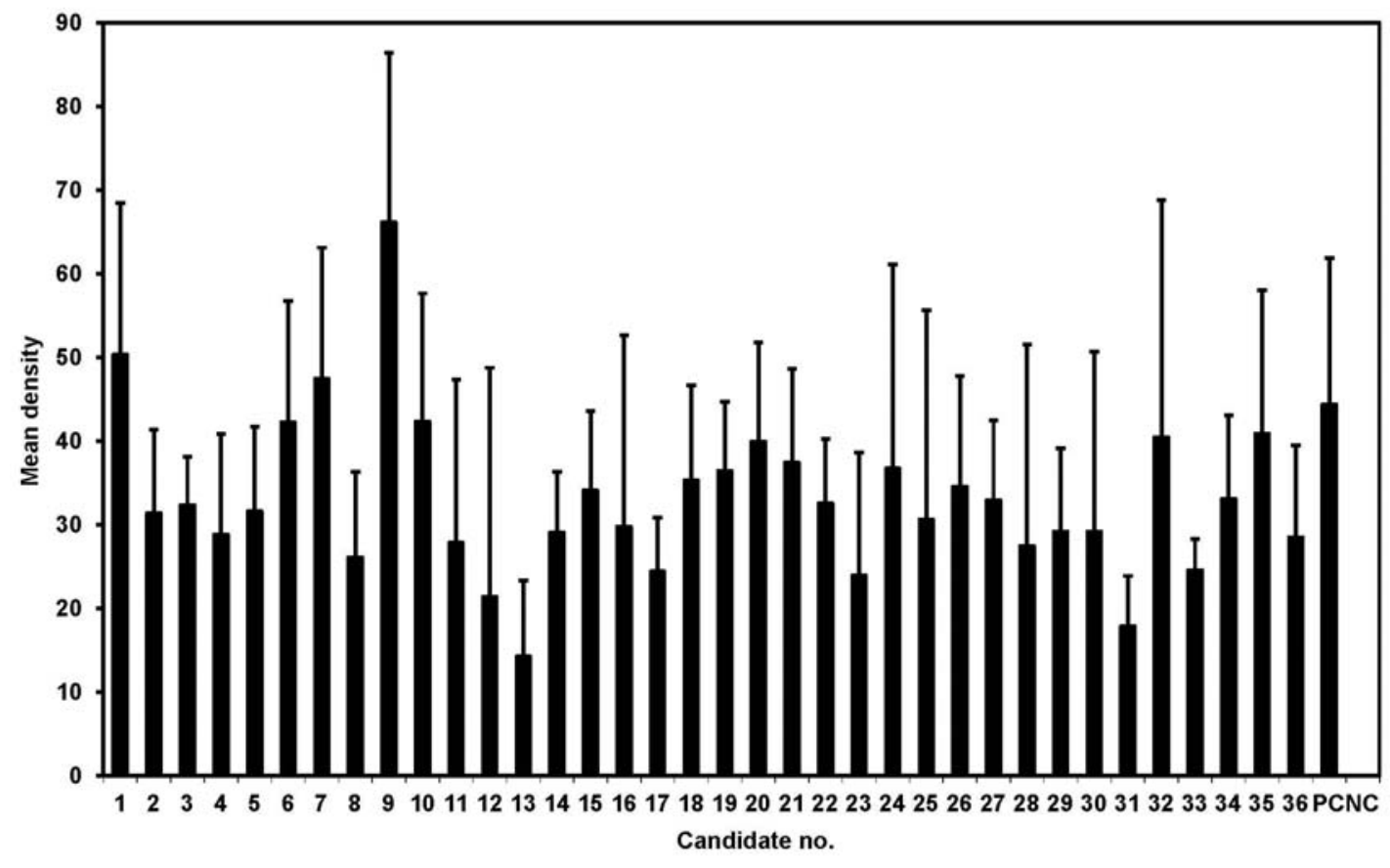

Fig. 1.

A, Yeast two-hybrid interaction assay of BNYVV P25 with 36 different $R z 2$ sugar beet candidate proteins. P25 was fused to LexA-BD (pEG202-P25) and Rz2 sugar beet cDNA library clones to B42-AD (pJG4-5-library- no. 1-36). The bait and prey combinations, co-transformed into yeast, were selected on medium containing galactose and lacking -Leu, -Trp, -Ura and -His. 
B, Test for transcriptional autoactivation of the -Leu reporter gene: pEG202 cotransformed with pJG4-5-library-no. 1 to 36. C, YTH interaction positive control (PC) LTA (pJG4-5-LTA) with P53 (pEG202-P53), negative control (NC) and autoactivation control (both pJG4-5 + pEG202). D, Relative quantification of Leudriven GFP fluorescence in yeast cell matings expressing the same P25 and cDNA (no. 1-36) as in (A) measured by display total area density of the mean yeast cell fluorescence signal (total of20 cells) measured in epifluorescence microscopy

Nucleotide sequences of the cDNAs were obtained, and coding sequences were used for NCBI Genbank database homology BLAST search using BLASTn algorithm. The cDNA sequences were translated and the amino acid sequences additionally applied for a database search making use of the "Simple Modular Architecture Research Tool" (SMART 5) for identification and analysis of domain architectures. The results of these database analyses including functional categorization and prediction of putative role in the virus-host interaction i.e. involvement in virus life cycle or antivirus resistance are summarized in Table 1. 


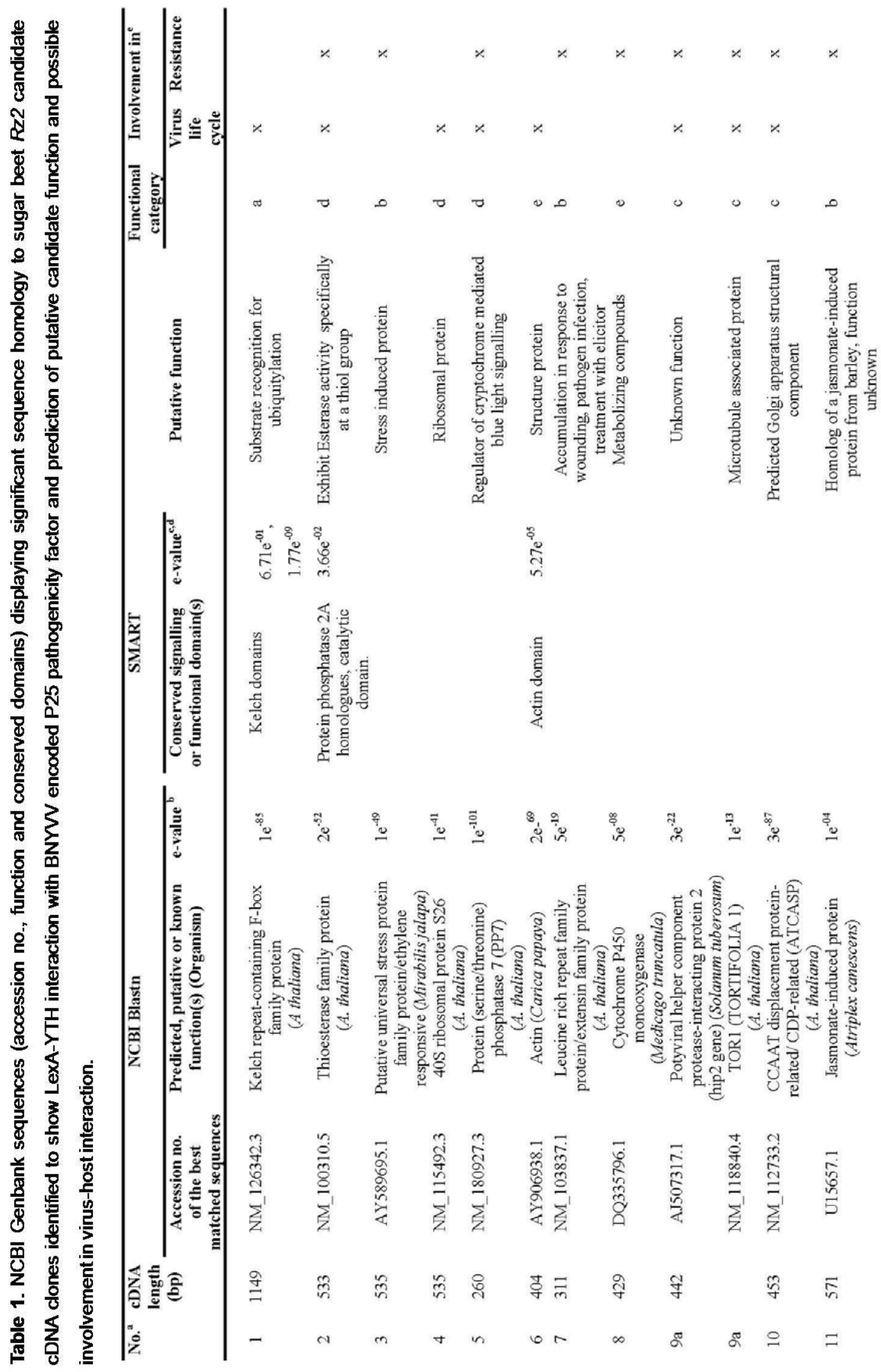



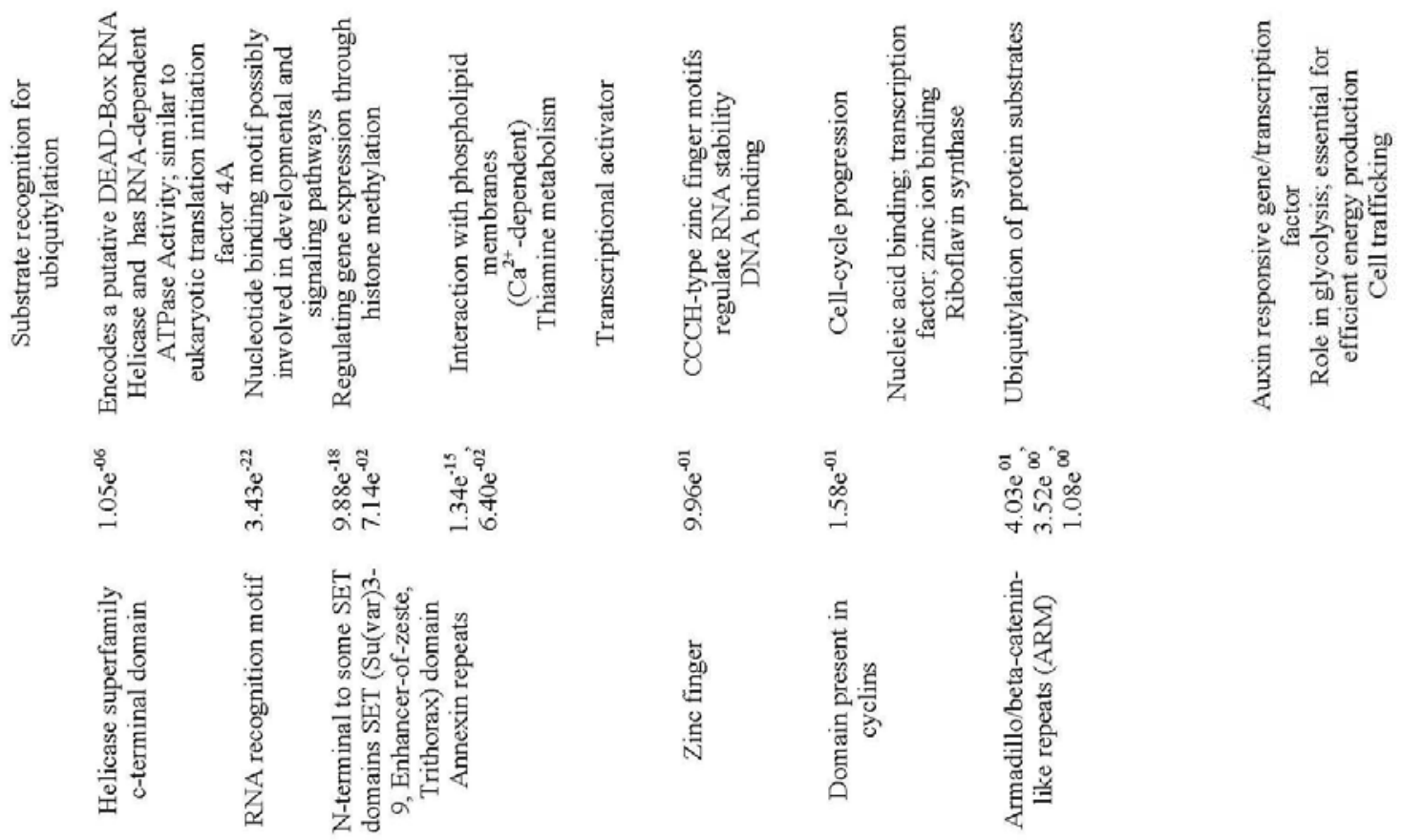

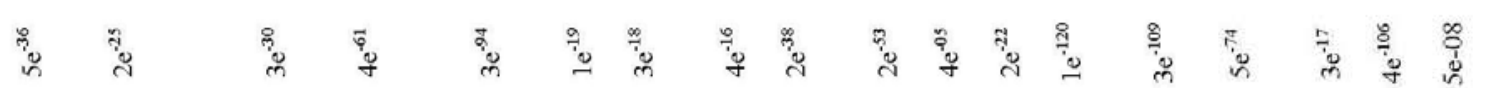

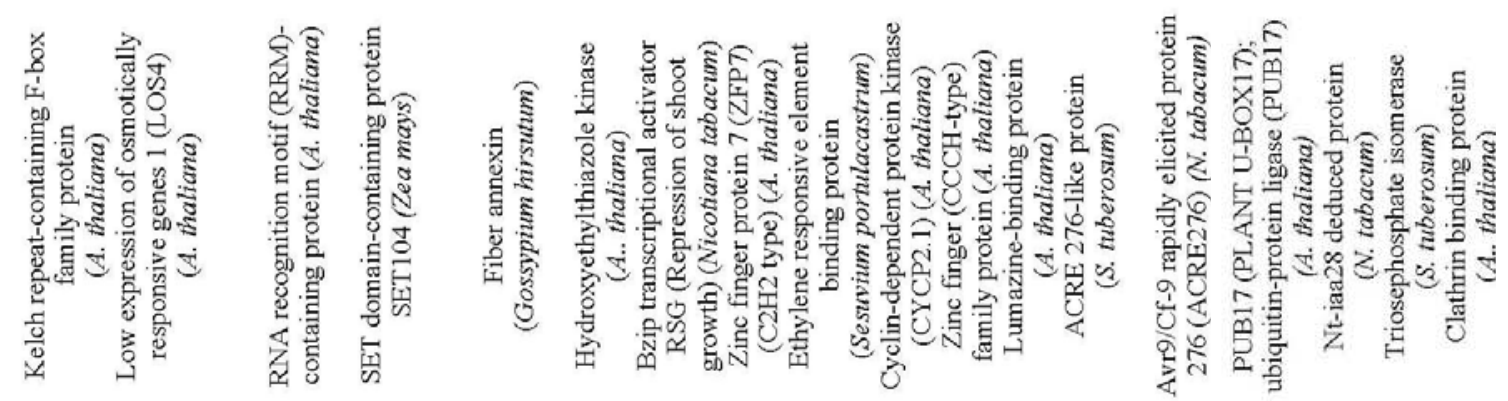

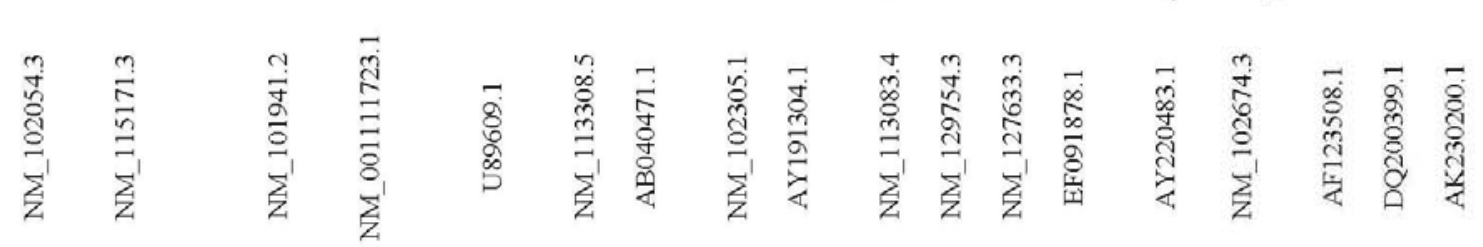

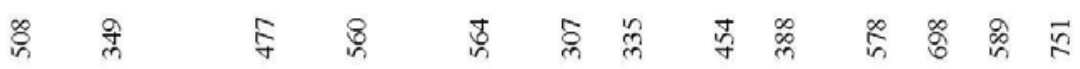

可要学

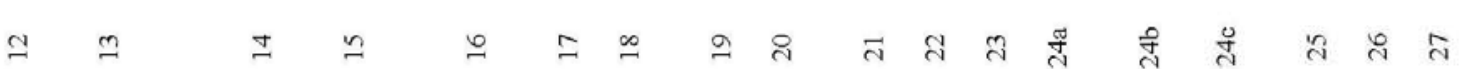

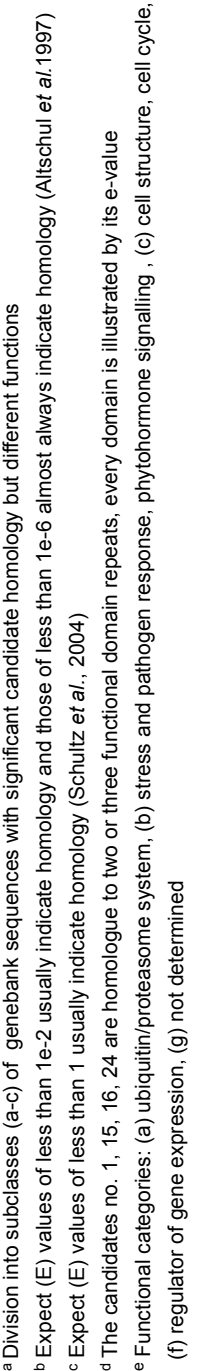


Out of 36 cDNA sequences analyzed, 27 cDNA encoded sugar beet candidate $\mathrm{P} 25$ interacting proteins displayed significant $\left(E\right.$ value below $1 \mathrm{e}^{-04}$ ) homology to plant gene products with known functions. Nine candidate clones did not display significant homology to plant sequences with known functions (pJG4-5-28 to -36). The cDNA inserts of these clones displayed a length of 602 bp (no. 28), $454 \mathrm{bp}$ (no. 29), 527 bp (no. 30), 433 bp (no. 31), 497 bp (no. 32), 541 bp (no. 33), 788 bp (no. 34), 452 bp (no. 35) and 505 bp (no. 36), respectively. SMART database analysis revealed conserved functional or signaling domains for 10 out of 27 candidates (candidate no. 1, 2, 6, 13, 14, 15, 16, 19, 21 and 24). In most cases, the SMART analysis confirmed the results of the BLAST search. The proteins identified in the Genbank BLAST search, showing significant homology to the P25 interacting sugar beet candidates, displayed known or at least putative functions. In accordance to their biological role all database matches corresponding to candidate no. 1-27 were classified into the following categories: a) ubiquitin/proteasome system, b) stress, pathogen response and phytohormone signaling, c) cell-structure, cell cycle and cell trafficking, d) translation and protein modification, e) (general) metabolism, f) regulators of gene expression. Interestingly, 3 out of 27 candidates, no.1 (1149 bp), 12 (508 bp) and 24 (751 bp) displayed significant homology to plant proteins involved in the ubiquitin/proteasome system (UPS), a key regulator for many biological processes in plants. In principle, the system regulates protein stability by covalently attaching ubiquitin to target proteins for $26 \mathrm{~S}$ proteasome degradation. Besides phytohormone signaling, light signaling, organ initiation and patterning, UPS is now known to be essential for plant defense against pathogens. The candidates 1 and 12 are similar to kelch repeat-containing F-box family proteins from $A$. thaliana responsible for substrate recognition in the ubiquitylation process as member of the E3 ligase complex. No. 24, a candidate with high homology to three different known sequences is also involved in the ubiquitylation process as plant U-box protein from $A$. thaliana known as an E3 ligase.

Candidate proteins interacting with P25 in yeast displaying homology to proteins involved in stress and pathogen response as well as phytohormone signaling (candidate no. 3, 7, 11, 20,25) were summarized in one category. Candidate no. 3 matched best in Genbank analysis with an ethylene responsive putative universal 
stress protein from $A$. thaliana. Leucine rich repeat family proteins/extensin family proteins ( $A$. thaliana), to which candidate no. 7 possessed highest homology, are essential for cell wall assembly and growth by cell extension and expansion and are known to be induced by auxin, biotic or abiotic stress. Candidate no. 11 revealed significant homology to a plant jasmonate-induced protein with unknown function. An ethylene responsive element binding protein with putative DNA binding/transcription factor abilities (S. portulacastrum) resulted from candidate no. 20 Genbank search. Candidate no. 25 showed high homology to a putative auxin responsive gene/transcription factor from $N$. tabacum belonging to the early auxinresponsive Aux/IAA gene family.

From rhizomania root-proliferation symptomatology it has been deduced that BNYVV influences root hair morphogenesis, cell division and elongation. Therefore, candidates with a putative participation in cell structure, cycle and trafficking were classified into one category. Candidate no. 6 showed high homology to actin (Carica papaya) and no. 9 to a microtubule associated protein named TOR1 ( $A$. thaliana) which regulates the orientation of cortical microtubules and the direction of organ growth. The protein plays a role in control of microtubule dependent anisotropic cell elongation. The homologue with the highest expected value to candidate no. 10 is predicted to represent a structural component of the Golgi apparatus which is known to be involved in protein modification as well as in synthesis and modification of membranes and cell walls. This cDNA candidate displayed homology to a regulator of gene expression: CCAAT displacement protein-related/ CDP-related (ATCASP - defined as 'cut alternatively spliced product' from A. thaliana). Candidate no. 16 displayed homology to fiber annexin and candidate no. 27 to a clathrin binding protein (A. thaliana), known to be involved in membrane vesicle formation.

Four candidates were classified into the category 'translation and protein modification'. Candidate no. 2 revealed high homology to thioesterase proteins ( $A$. thaliana), which belong to the class of hydrolases, however, SMART search resulted in the identification of a conserved protein phosphatase domain. In addition candidate no. 5 showed homology to another $A$. thaliana serine/threonine protein phosphatase. Candidate no. 13 revealed high homology to an eukaryotic translation initiation factor (A. thaliana). 
Following Genbank search, three sugar beet encoded proteins isolated within the P25 YTH screen were found to be putatively involved in cell metabolism, namely: no. 8 with high homology to a Cytochrome P450 monooxygenase ( $M$. truncatula), no. 23 with a putative involvement in riboflavin synthesis ( $A$ thaliana) and no. 26, displaying high homology to a triosephosphate isomerase (S. tuberosum). In total, four candidates (14, 15, 19 and 22) could be associated with regulation of gene expression. The best match sequence to candidate no. 14 revealed an RNArecognition motif ( $A$. thaliana), which has been found in splicing factors, translation initiation factors and other RNA-binding proteins. The SET-domain, identified in SMART search of candidate no. 15 is regularly found in methyltransferases i.e. histone methyltransferases which regulate gene expression (Z. mays). Candidate no. 18 displayed homology to a transcriptional activator from $N$. tabacum. Finally two candidates (no. 19 and 22) were significant homologues to Zinc-finger (C2H2and $\mathrm{CCCH}$-type respectively) motifs which can be found in transcription and splicing factors ( $A$. thaliana).

\section{P25 interacts with several YTH identified candidate proteins in living plant cells.}

To confirm the interaction of sugar beet candidate proteins with P25 using an in planta BiFC with monomeric red fluorescent protein (mRFP1) was selected (Jach et al. 2006; Walter et al. 2004). Two binary vectors for agrobacterium-mediated transient expression were constructed, expressing P25 or a cDNA encoded candidate fused to the $\mathrm{N}$-terminal 177 amino acids or the C-terminal 66 amino acids of mRFP1, respectively, driven by the Cauliflower mosaic virus (CaMV) 35S promoter and polyadenylation signal. To validate the system for its suitability to detect the physical interactions of two proteins, a positive control was developed. As E. coli $\beta$-glucuronidase (GUS) is known to form tetramers (Bracey and Paigen, 1987), it was applied for the in planta BiFC analysis using the newly constructed vectors. Agroinfiltation of mRFP-C-GUS and -N-GUS led to visible reconstitution of mRFP fluorescence at $5 \mathrm{dpi}$ (Fig. 2A), whereas infiltration of mRFP-N-GUS plus mRFP-C-empty did not (Fig. 2B) as observed under epifluorescence microscopy (FM). GUS expression was verified in total leaf protein extracts with HA and c-myc specific antibodies at the expected size of $75 \mathrm{kDa}$ (plus the mRFP-C or mRFP-N) 
(Fig. 3). Subsequently all 36 sugar beet encoded cDNA candidate genes were cloned into pBin-mRFP-N. The assay was repeated with mRFP-C-P25 plus mRFP-N-expressing each of the different (YTH-selected) cDNA-candidates. 10 of 36 candidates namely candidate no. $6,7,9,10,14,16,22,26,27,28$ and 33 displayed reconstitution of mRFP fluorescence at $5 \mathrm{dpi}$ when co-infiltrated with P25 (Fig. 2C-L). This fluorescence based detection of in planta interaction was not detected when P25 or the candidate was transiently expressed alone (data not shown). In all cases, detectable mRFP red fluorescence coincided with detection of the candidate-mRFP fusion expression (Fig. 3). Remarkably, the expression level correlated roughly with the strength of the fluorescing signal (e.g. candidate no. 14, 16, 22). Strong interactions of cDNA-P25 showed lower fluorescence (i.e. candidate no. 14 and 16) than the others. All remaining 26 mRFP-N-candidate fusions did not result in detectable mRFP reconstitution, when co-infiltrated with mRFP-P25. Out of the candidates where interaction in yeast could not be confirmed, expression of eight candidates (no. 3, 4, 5, 22, 29, 31, 32, and 33) were detectable in western blot analysis of total leaf protein extracts following $N$. benthamiana agroinfiltration. Therefore these were considered to represent additional false-positive P25 interactors and were excluded from further evaluation. Although independent repetitions were performed, the other 18 candidates did not show any expression beyond western blot detection level. 

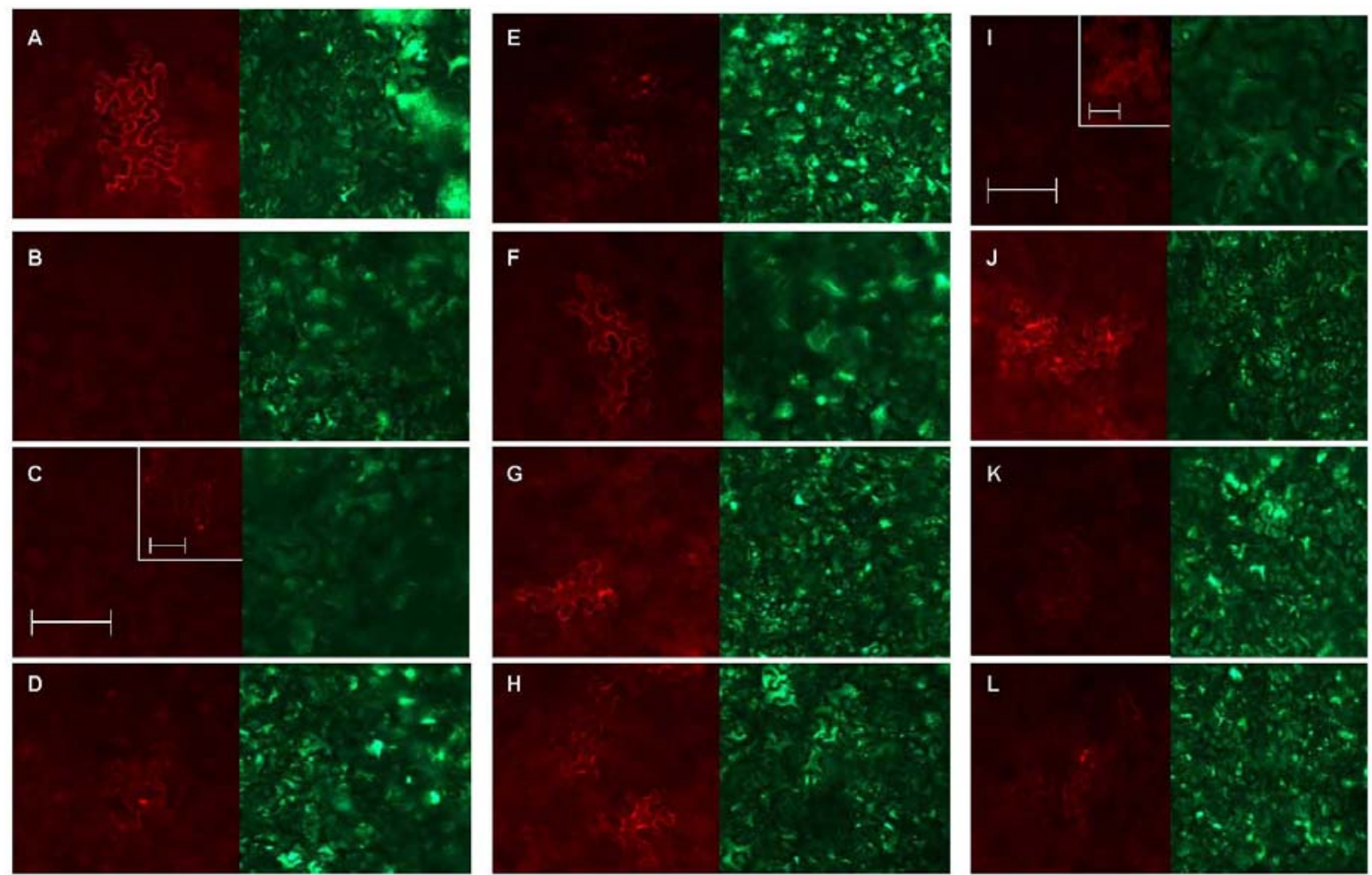

Fig. 2.

Bimolecular fluorescence complementation (BiFC) visualization of BNYVV P25 in planta interaction with several $R z 2$ sugar beet cDNA encoded candidate proteins initially identified in YTH library screen.

Photos of epifluorescence microscopy (200x) mRFP analysis and bright field microscopy of BiFC assay. N. benthamiana leaf epidermis cells at 5 dpi following agroinfiltration with mRFP-C and $-\mathrm{N}$, fused to P25 and sugar beet candidate interactors respectively. A, positive control: E. coli $\beta$-glucuronidase (GUS) tetramerization, $\mathbf{B}$, negative control: mRFP-N-GUS plus mRFP-C-empty, C-L, mRFP-C-P25 plus mRFP-N-cDNA-candidate, C, no. 6; D, no. 9; E, no. 10; F, no. 14; G, no. 16 ; H, no. 22 ; I, no. 26 ; J, no. 27 ; K, no. 28 ; L, 33; bar in photos $\mathrm{C}$ and I represent a length of $50 \mathrm{~nm}$ 


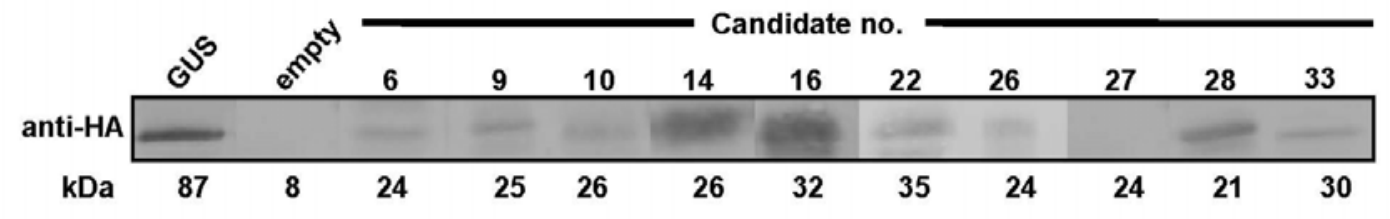

Loading control

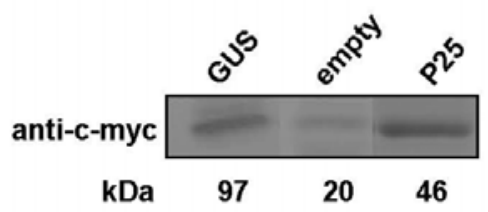

Loading control

Fig. 3.

Immunodetection of transiently expressed mRFP-C-P25 and mRFP-N-candidate fusions tagged with haemagglutinin ( $\mathrm{HA}$ ) and c-myc respectively in $\mathrm{BiFC}$ assay in total $N$. benthamiana leaf proteins. A, HA based detection (with specific antiserum) of mRFP-N-candidate fusions (sizes in $\mathrm{kDa}$ indicated below the signals) and mRFP-N-GUS positive control. B, C-myc based detection (with specific antiserum) of mRFP-C-P25 and mRFP-C-GUS positive control. C, SDS-PAGE Coomassiestained loading control corresponding to $(A)$ and $(B)$

\section{DISCUSSION}

In this study we aimed to obtain first insights into the virus-host interaction by identifying sugar beet proteins from a resistant genotype showing physical interaction with P25 and to deduce their putative biological role. To our knowledge, this study represents the first systematic YTH cDNA library screen of sugar beet using a viral pathogenicity factor as bait. Although the proof of biological significance of the interactions detected is missing, the data represent a first step towards understanding of cellular life cycle of BNYVV and gives a first indication of how the resistance might control virus replication and systemic spread.

The sugar beet genome consists of $758 \mathrm{Mbp}$ encoding approximately 25,000 genes (Kole 2007). The cDNA library containing ca. $1.4 \times 10^{6}$ independent clones resulted in a calculated 18 -fold coverage of the sugar beet proteome, which is 
comparable to cDNA libraries applied in other successful YTH-studies [e.g. N. tabacum cDNA library, $1.55 \times 10^{6}$ clones, 15 -fold coverage (Soellick et al. 2000) and $A$. thaliana library $1 \times 10^{6}$ clones, 13-fold coverage (Pazouhandeh et al. 2006)]. The high redundancy might explain the fact that no P25 interacting protein was isolated more than once from the library, although several hundred colonies were picked for further analysis. The de-selection process of false-positive candidates with transcription autoactivation ability can be considered as highly quantitative because it was performed in two repetitions in independent assays using liquid and solid media with different plating densities, respectively, leading to $85 \%$ (384/450) de-selected candidates. As in the BiFC approach 18 translational fusions of candidate proteins with mRFP did not lead to detectable transient expression, which might be explained by protein instability, we will not exclude these candidates from evaluation. These $18 \mathrm{BiFC}$ non-expresser candidates and the remaining eight candidates, which did not display in planta BiFC interaction, although being expressed should be used in further studies to confirm the yeast interaction. Remarkably, many of the candidates could be assigned to a function with a plausible relation to the virus life cycle or plant resistance.

The screen revealed three different P25 interactors with high homology to F- and U-box proteins (no. 1, 12 and 24) placed in category a. Multiple studies have found evidence that mammalian as well as plant viruses try to overcome the stoichiometric imbalance of host proteins over virus proteins by directing their target plant proteins to the $26 \mathrm{~S}$ proteasome, acting mainly at the point of substrate recognition (reviewed in Banks, 2003). Among plant RNA (and DNA) virus proteins, this function has been identified as an additional mode of action and was demonstrated to be connected to proteins with various functions including silencing suppressor proteins (Jin et al. 2007; Pazhouhandeh et al. 2006), movement proteins (Reichel \& Beachy 2000) and cell cycle regulators (Aronson et al. 2000). In contrast to virus proteins which mimic an F-box (Aronson et al., 2000; Pazhouhandeh et al. 2006) an F-box motif was not predicted in P25 (data not shown). The biological relevance of the interference of BNYVV P25 with the proteasome remains unknown but a connection of P25's role in enhancing virus replication and spread mediated by influencing the turnover of host proteins seems plausible. Interestingly, upregulation of a sugar beet ubiquitin gene following 
BNYVV infection was reported in the recent transcriptome analysis of a susceptible genotype (Schmidlin et al. 2008).

Necrotic root hairs and a taproot with brownish vasculature are indicative for a resistance reaction which is unable to limit the virus spread and reflects a stressed tissue status. This is supported by the results of the studies on the effect of BNYVV changes in the sugar beet proteome, where several phytohormone and stress response related proteins were identified, including auxin-related proteins and one abscisic acid induced protein (Larson et al. 2008). The elevated auxin contents monitored in early studies (Pollini et al. 1990) and the abnormal root hair synthesis and proliferation are probably induced by the virus to increase the number of host cells for the obligate biotrophic $P$. betae vector. Consistently, Schmidlin et al. (2008) detected virus induced increased expression of the sugar beet auxin binding protein 1 gene (ABP1). As virus symptoms are dependant on P25 presence, it was not surprising to find a P25 interaction with proteins related to phytohormone metabolism (category b) like candidate no. 25 with high homology to Nt-iaa deduced protein known as auxin responsive gene product (Dargeviciute et al. 1998). The authors described that Aux/IAA-related proteins play a regulatory role in auxin-induced events during cell elongation. The high homology of candidate no. 20 to an ethylene responsive element binding protein with key regulatory functions in developmental processes (Jiménez et al. 2005; Leubner-Metzger et al. 1998) suggests another phytohormone related gene to be a P25 target. The coincidence of candidate no. 7 identification with high homology to an LRR-extensin family protein is striking, and in agreement with the findings of Schmidlin et al. (2008) who detected BNYVV induced upregulation of a sugar beet extensin gene. Extensin is known to be a key regulatory element of cell-wall development (Cassab 1998) that can be induced by wounding and pathogen infection or abiotic stress (Merkouropoulos et al. 1999; Merkouropoulos and Shirsat 2003; Takemoto et al. 2001). Hence, it seems plausible that P25 targets this protein to suppress a stress response. When we subjected the best matched candidate no. 7 sequence (NM_103837.1) to BLAST search (Blastn algorithm, data not shown), another Arabidopsis LRR-extensin that regulates root hair morphogenesis and elongation was identified (acc. no. NM_101076). Interestingly, null mutants of this allele developed root hairs that frequently abort, swell, or 
branch (Baumberger et al. 2001) suggesting that P25 might interfere with candidate no. 7 to induce virus symptoms. Future studies using the allele from susceptible plants will be necessary to detect a polymorphism and to confirm the biological relevance of this hypothesis.

Consistent with the proteomic study which identified BNYVV upregulation of cellcycle and cell structure related transcripts and proteins (Larson et al. 2008), we isolated six P25 interacting candidates putatively connected to these processes (category c). Actin (no. 6) and fiber annexin (no. 16) are components of the cytoskeleton. Members of the actin multigene family are differentially expressed during plant development ( $\mathrm{Li}$ et al. 2005) whereas plant annexins are involved in membrane processes and represent an important element of the calcium signaling pathway (Konopka-Postupolska et al. 2007). Annexin was found to function in plant stress response (e.g. osmotic stress) and due to annexin-actin interaction a signaling function was proposed (Calvert et al. 1996). We therefore suggest the hypothesis that P25 targets these proteins as an additional interference to root hair morphogenesis and cell wall synthesis or alternatively influence a possible actinannexin mediated signal transduction. Candidate no. 27 displayed significant homology to an Arabidopsis clathrin binding protein. As clathrin possesses a key position in cell division and protein trafficking through endocytic pathways and controls formation of membrane internalization (Pérez-Gómez and Moore, 2007). Clathrin-coated vesicles have been associated with rapidly growing cells like root hair tips (Holstein, 2002) this pathway might represent another P25 target for the interference with root morphogenesis. In addition to P25 proteasome interference, possible similarties to a potyvirus silencing suppressor (HC-Pro) are given (Jin et al. 2007). To our surprise, another candidate with homology to a HC-Pro interacting protein was revealed in our screen. Candidate no. 9 showed homology to a HC-Pro interacting protein (HIP2) with unknown functions previously isolated from potato (Guo et al. 2003). The second match of this BLAST search however was an Arabidopsis protein responsible for cortical microtubules playing an important role in the regulation of the direction of cell expansion (TOR1). Although the virus genera (Potyvirus and Benyvirus) do not show close phylogenetic relation and their gene expression strategies are divergent, these results suggest a similar mode of action of both pathogenicity factors. 
The candidates assigned to the categories $d$, e and f show similarity to genes with common functions in the translation and protein modification, cell metabolism and gene expression. Therefore the biological significance of the P25 interaction for them remains speculative. For example Larson et al. (2008) also identified proteins induced in primary and secondary metabolism, without any associated role in relation to viral-host interactions.

The YTH screen of an Rz2 sugar beet cDNA library of high quality with the BNYVV encoded P25 in comparison to screens with other viral pathogenicity factors (Guo et al. 2003, Pazhouhandeh et al. 2006, Jin et al. 2007, Anandalakshmi et al. 2000) uncovered an outstanding number of candidates possibly involved in virus pathogenicity/virus life-cycle or plant resistance response in sugar beet. There is no doubt that additional interaction tests with each of the candidates, where BiFC assay failed, are necessary to prove these interactions. With high probability, isolation of full-length sequences from susceptible and resistant genotypes for sequence comparison and YTH repetition, as well as, genomic mapping will reveal sugar beet antivirus resistance factors leading to a better understanding of this plant virus interplay.

\section{MATERIALS AND METHODS}

Yeast two-hybrid (YTH) system, yeast strains, plasmids and medium.

Saccharomyces cerevisae strains EGY48 (MATa, trp1 his3 ura3 leu2::6 LexAopLEU2) (Estojak et al. 1995) and RHY206 (MATa trp1D::hisG his3D200 ura3-52 lys2D201 leu2-3) were obtained from MoBiTec (Göttingen, Germany) and Origene Technologies Inc. (Rockville, MD., U.S.A.) respectively. Yeast full media, selective drop-out media and amino acid (aa) stock solutions (YPD and YNB-DOB) supplemented with glucose or galactose (glu/gal) were prepared using standard

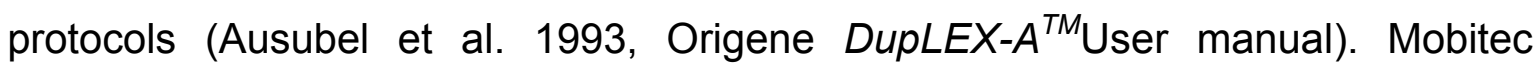
Grow'n'Glow GFP Two-Hybrid System (MoBiTec, GmbH Göttingen, Germany) is a modified version of the LexA/B42 YTH system originally developed by (Fields and Song, 1989). It consists of the bait plasmid pEG202, the prey plasmid pJG4-5 (Gyuris et al. 1993) and a reporter plasmid pGNG1 (Cormack et al. 1998) containing the GFPuv variant (Crameri et al. 1996) under control of four copies of 
the lexA operators within a minimal $G A L 1,10$ promotor. Plasmids were propagated in E. coli DH5a.

\section{Molecular biology techniques.}

All plasmid manipulations were performed according to standard techniques (Sambrook et al. 1989) unless otherwise specified. Manipulations were verified through sequencing (MWG Biotech AG, Martinsried, Germany).

\section{Cloning of the P25 ORF into pEG202 YTH bait plasmid.}

Plants of a BNYVV susceptible sugar beet hybrid (cultivar Tatjana, kindly supplied by KWS Einbeck, Germany) were grown in a German field soil sample infected with rhizomania pathotype $B$ (soil origin: Büttelborn) for 4 weeks in the greenhouse. Total RNA (Hamilton et al. 2002) was prepared from (BNYVV infected) lateral roots and the entire BNYVV P25 of RNA3 encoded open reading frame (ORF) (nt. 447-1103 in Genbank Acc. no. M36894) was RT-PCR amplified with specific primers P25-up (5'-TTGAATTC ATGGGTGATATATTAGGCG-3', restriction sites in italics and viral nucleotides underlined) and P25-low (3'TACCTCGAGCTAATCATCATCATCAACAC-5') introducing restriction sites ECORI and $X$ hol and subsequently cloned into the plasmid pEG202 to obtain a translational fusion of P25 with the LexA DNA binding domain (BD). The B-type P25 ORF insert was verified through sequencing revealing a composition of the amino acid tetrad pos. 67-70 of AYHR.

\section{Construction of a sugar beet cDNA library.}

Plants of a homozygous sugar beet breeding line (8T_0015, kindly supplied by KWS, Einbeck, Germany) carrying the Rz2 BNYVV resistance gene, were grown in the above described BNYVV B-type infested soil for 4 weeks. Root and leaf tissue was harvested and used together for preparation of $2 \mu \mathrm{g}$ total RNA. Generation of the cDNA library in pJG4-5 was carried out by "vertis" Biotechnology AG (Freising-Weihenstephan, Germany). The cDNA synthesis was carried out with M-MLV RT and a random linker primer containing an Xhol restriction site. Synthesis of the second strand was achieved with a second linker primer containing ECORI (5'-GAATTCCATCAGGCAGAGGACGAGACAGAACGCA-3', 
restriction site in italics) and Klenow Polymerase. After PCR amplification, normalization and size fractionation of cDNAs greater than $0.4 \mathrm{~kb}$, the library was EcoRl-Xhol cloned into pJG4-5 to obtain a translational fusion of the cDNAs with the activation (AD) domain B42 and hemagglutinin epitope tag (HA-tag). In total, the library contained a number of $1.4 \times 10^{6}$ recombinant clones.

\section{Yeast transformation and YTH sugar beet Rz2 cDNA library interaction screen with BNYVV P25 applying quantitative liquid mating.}

The pJG4-5 cloned sugar beet cDNA library $\left(1.4 \times 10^{6}\right.$ independent clones) was quantitatively transformed into yeast strain EGY48 (MATa) following the "HighEfficiency Transformation Protocol" of (Gietz and Woods, 2002) with slight modifications. As carrier DNA, denatured Herring Testes DNA (Clontech), (10 $\mathrm{mg} / \mathrm{ml}$ ) was used, the incubation time was increased to 1 hour and centrifugation was carried out at $3.000 \times \mathrm{g}$. Approximately $5.2 \times 10^{8}$ colonies growing on selective medium [YNB-DOB-(glu)-trp] were propagated, pooled and stored in aliquots at $-70^{\circ} \mathrm{C}$, following the method described in (Soellick and Uhrig 2001). $50 \%$ of the cells in thawed aliquots were determined to be viable. pEG202-P25 and pGNG1 were co-transformed into RHY206 (MATa) selected on YNB-DOB(glu)-ura-his and tested for transcriptional autoactivation of LexA controlled (pGNG1 encoded) GFPuv and (genome integrated) LEU2 reporter genes. The empty plasmid pJG4-5 was supertransformed into RHY206 (pEG202-P25, pGNG1) and re-tested for autoactivation [YNB-DOB-(glu)-ura-his-trp]. Quantitative liquid mating under optimized conditions of freshly grown RHY206 (pEG202-P25, pGNG1) with a melted long-term culture aliquot of EGY48 (pJG4-5-cDNA-library) was carried out as described in (Soellick and Uhrig 2001) and double transformed zygotes were selected [YNB-DOB-(gal)-ura-his-trp-leu]. Both cultures were mixed for mating at a ratio Mata:Mata of 2,5:1 with a cell density of $6 \times 10^{8}$ (Bait/GFP cells $3.75 \times 10^{8}$ : prey cells: $\sim 1.5 \times 10^{8}$.). The mating reaction was plated [YNB-DOB(gal)-ura-his-trp-leu] at a density of $2 \times 10^{5} \mathrm{cells}^{*} \mathrm{~cm}^{-2}$ resulting in a mating efficiency calculated by numbers of zygotes in ratio to total cells (including dead cells) of $11 \%$. The number of double transformants was calculated as $7 \times 10^{8}$. GFP-fluorescing colonies (450) were identified with a hand-held long-wave ultraviolet (UV) lamp (Blak Ray model B 100 AP, 100W, UV products Upland, CA), 
re-streaked on solid selective media and tested for autoactivation in liquid medium [YNB-DOB-(glu)-ura-his-trp-leu] to de-select transcriptional autoactivator cDNAs. 37 candidate interactors with no detectable autoactivation activity were applied for further analysis. Plasmid DNA from yeast was recovered using the protocol described in (Origene DupLEX-A $A^{T M}$ User manual). To selectively recover only pJG4-5 cDNA library plasmids, each isolated yeast plasmid DNA was transformed into E. coli strain KC8 (pyrF, leuB600, trpC, hisB463) auxotrophic for tryptophane and re-isolated on minimal media (M9, (Sambrook and Russell 2001) lacking tryptophan and supplemented with Ampicillin. All candidate pJG4-5 cDNA library plasmids were re-transformed into EGY48 and liquid mated with RHY206 (pGNG1+pEG202-P25) following the method described (Yeast Protocols Handbook 2008, Clontech Laboratories Inc.) For each interaction mating of a candidate with P25, a test for autoactivation was performed by mating with RHY206 (pGNG1+pEG202-empty). $5 \mu$ of dilutions series $\left(10^{0}-10^{-5}\right)$ of the mating reaction was spotted on selective medium. At 5-7 days incubation, both matings were checked for interaction and autoactivation respectively. Only candidates displaying yeast growth at 100-fold higher dilution than the autoactivation control were considered to be non-transcriptional autoactivators. In all yeast two-hybrid interaction assays, appropriate positive controls consisting of mouse P53 (Iwabuchi et al. 1993) fused with DNA-BD (pEG202-P53) and LTA fused with DNA-AD (pJG4-5-LTA) were included (Li and Fields, 1993). Total area optical density analysis of GFP fluorescence was carried out using epifluorescence microscopy of yeast cells carried out with Gel-Pro analyser software 6.0 (Media Cybernetics).

\section{Total yeast and plant protein extraction, SDS-PAGE, electroblot.}

Proteins were extracted from yeast cells following the method of (Horvath and Riezman, 1994) with modified extraction/SDS-sample buffer (0.02 M Tris pH8.0, $0.2 \mathrm{mM}$ EDTA, $2 \%$ SDS, $10 \%$ mercaptoethanol, $20 \%$ glycercol, $0.05 \%(\mathrm{w} / \mathrm{v})$ bromphenolblue).

Extraction of total plant proteins was carried out by grinding $100 \mathrm{mg}$ agroinfiltrated $N$. benthamiana leaf tissue in liquid nitrogen. The frozen leaf powder was transferred into $1.5 \mathrm{ml}$ tube and filled up with $500 \mu \mathrm{l}$ extraction buffer $\left(95^{\circ} \mathrm{C}\right)$. The 
homogenized sample was boiled for $5 \mathrm{~min}$ and centrifuged for $5 \mathrm{~min}$ at $11.000 \mathrm{x} \mathrm{g}$. The protein samples $(20 \mu \mathrm{l})$ were separated by $15 \%$ SDS-PAGE and electroblotted on nitrocellulose (Amersham) for LexA-detection or PVDF (Roche) membranes for HA- and c-myc detection.

\section{Immunodetection of HA, LexA and c-myc tagged proteins.}

After blocking the membrane with 2\% (HA and c-myc) or 1\% (LexA) skimmed milk, immunodetection of HA was carried out using anti HA-high affinity rat monoclonal antibody (Roche 11867423 001, 1/800) and alkaline phosphatase (AP) conjugated goat anti-rat IgG (whole molecule) (Sigma A9654, 1/7000). LexA was detected with polyclonal rabbit anti-LexA (Invitrogen 46-0710, 1/5000) and APconjugated goat anti-rabbit polyclonal antibody (Sigma A3687, 1/10000). C-myc was probed with anti c-myc mouse monoclonal IgG (Roche 11667149001 , 1/500) and AP-conjugated goat anti-mouse IgG (BioRad 170-6520, 1/500). Detection was performed using chromogenic substrates BCIP (5-Bromo-4-chloro-3'-indolyphosphate p-toluidine salt) and NBT (nitro-blue tetrazolium chloride) reagents (Applichem).

\section{Sequence analysis.}

The entire cDNA inserts of library derived candidate genes were determined by a commercial company (MWG Biotech AG, Martinsried, Germany) with standard primers flanking the multiple cloning site of pJG4-5 and applied for database comparison using the nucleotide blast program with the Blastn algorithm within the basic local alignment search tool (BLAST) using the NCBI database (http://www.ncbi.nlm.nih.gov/blast/) (Altschul et al. 1997). The search was limited to sequences from the taxa Viridiplantae (taxid:33090).

cDNA sequences were translated with VectorNTI software (Invitrogen, Germany) and applied for the Web-based "Simple Modular Architecture Research Tool" (SMART 5) analysis (http://smart.embl-heidelberg.de/) to identify functional and signaling domains within the sugar beet protein sequences (Schultz et al. 1998; Letunic et al. 2006). 


\section{In planta bimolecular fluorescence complementation assay (BiFC).}

The red BiFC system based on improved monomeric red fluorescent protein (mRFP1-Q66T) (Jach et al. 2006) was adapted to the specific needs of the library clones. The coding sequence of mRFP1-Q66T mutant was kindly provided by J. Uhrig (University of Cologne, Germany). In accordance to (Jach et al., 2006) the coding sequences for the $\mathrm{N}$-terminal aa 1-168 and C-terminal aa 169-225 were PCR amplified using specific primers. Between mRFP-N and P25, a c-myc tag and between mRFP-C and sugar beet coding region, a HA-tag was inserted by attaching the coding sequence to the lower mRFP-N and -C primers. A binary vector pBIN19 (Bevan, 1984) was supplied with an enhanced cauliflower mosaic virus 35S-promoter and polyA-terminator cassette (kindly supplied by E. Maiss, Leibniz University Hannover) (pBIN19-35S-pA). The mRFP-N-c-myc and mRFPC-HA PCR products were cloned into pBIN19-35S-pA, leading to pBIN19-mRFP$\mathrm{N}-\mathrm{c}$-myc and -C-HA. Primer sequences and plasmids are available on request.

The BNYVV P25 ORF was EcoRI-Xhol cloned into pBIN19-mRFP-N-c-myc. cDNAs from pJG4-5 clones displaying P25 interaction in yeast but no transcriptional autoactivation were cloned similarly into pBIN19-mRFP-C-HA. To obtain a BiFC positive control, the E. coli $\beta$-glucuronidase (GUS) open reading frame (Vancanneyt et al. 1990) was PCR reamplified from a GUS plant expression vector (pTQ-GUS-N, kindly supplied by E. Maiss) with specific primers introducing EcoRI and Xhol restriction sites to obtain a translational $\mathrm{N}$-terminal fusion with mRFP-N and mRFP-C for use in BiFC. Cloned sequences were verified by sequencing.

\section{Agrobacterium mediated transient expression BiFC assay.}

Binary vectors were electrotransformed into Agrobacterium tumefaciens strain C58C1 (pGV2260). A. tumefaciens cultures were prepared for agroinfiltration essentially as described (Voinnet et al. 2003) with an $\mathrm{OD}_{600}$ adjusted to 1.0. To suppress RNA silencing, a potyviral HC-Pro (35S-HC-Pro, (Varrelmann et al. 2007) of plum pox virus (PPV) was co-expressed by A. tumefaciens at an $\mathrm{OD}_{600}$ of 1.0 diluted (1:50). For transient expression assay, leaves of 4 weeks old Nicotiana benthamiana plants were co-infiltrated together with the helper component of PPV into epidermis cells of $N$. benthamiana and leaf patches were examined for mRFP 
fluorescence using epifluorescence microscopy (FM) at 3-5 dpi. As negative control pBIN-mRFP-N-GUS and pBIN-mRFP-C-cDNA and as positive control pBIN-mRFP-N-GUS and pBIN-mRFP-C-GUS were carried out. mRFP fluorescence was detected with FM (Leica DMR) using specific DsRed filters (Emitter HQ 620/60, Beamsplitter Q 585 LP, Exciter HQ 565/30). Photographs were taken using Leica DFC camera, DFC300 FX.

\section{ACKNOWLEDGEMENTS}

This research project has been carried out with the financial support of the Federal Ministry of Economics and Technology (BMWi), administered via the Arbeitsgemeinschaft industrieller Forschungsvereinigungen e.V. (AiF) and the Gemeinschaft zur Förderung der privaten deutschen Pflanzenzüchtung e.V. (GFP).

\section{LITERATURE CITED}

Acosta-Leal, R., Fawley, M.W., and Rush, C.M. 2008. Changes in the intraisolate genetic structure of Beet necrotic yellow vein virus populations associated with plant resistance breakdown. Virology 376:60-68.

Adams, M.J., Antoniw, J.F., and Mullins, J.G.L. 2001. Plant virus transmission by plasmodiophorid fungi is associated with distinctive transmembrane regions of virus-encoded proteins. Arch Virol. 146:1139-1153.

Altschul, S.F., Madden, T.L., Schaffer, A.A., Zhang, J.H., Zhang, Z., Miller, W., and Lipman, D.J. 1997. Gapped BLAST and PSI-BLAST: a new generation of protein database search programs. Nucleic Acids Res 25:3389-3402.

Anandalakshmi, R., Marathe, R., Ge, X., Herr, J.M. Jr, Mau. C., Mallory. A,, Pruss, G., Bowman, L., and Vance VB. 2000. A calmodulin-related protein that suppresses posttranscriptional gene silencing in plants. Science. 290:142144. 
Aronson, M.N., Meyer, A.D., Györgyey, J., Katul, L., Vetten, H.J,. Gronenborn, B., and Timchenko ,T. 2000. Clink, a nanovirus-encoded protein, binds both pRB and SKP1. J Virol. 74:2967-72.

Ausubel, F. M., Brent, R., Kingston, R. E., Moore, D. D., Seidman, J. G., Smith, J. A., and Struhl, K. 1994. Current Protocols in Molecular Biology (John Wiley \& Sons, Inc.) Vol. 1, Chap. 5.

Baumberger, N., Ringli, C., and Keller, B. 2001The chimeric leucine-rich repeat/extensin cell wall protein LRX1 is required for root hair morphogenesis in Arabidopsis thaliana.Genes Dev. 15:1128-1139.

Banks, L., Pim, P., and Thomas, M. 2003 Viruses and the 26S proteasome: hacking into destruction. TRENDS in Biochemical Sciences, 28: 452-459.

Bevan, M. 1984. Binary Agrobacterium Vectors for Plant Transformation. Nucleic Acids Res 12:8711-8721.

Biancardi, E., Lewellen, R.T., De Biaggi, M., Erichsen, A.W., and Stevanato, P. 2002. The origin of rhizomania resistance in sugar beet. Euphytica 127:383397.

Bracey L.T., and Paigen, K.1987 Changes in translational yield regulate tissuespecific expression of beta-glucuronidase. Proc Natl Acad Sci U S A. 84:9020-9024.

Calvert, C.M., Gant, S.J., and Bowles, D.J.1996. Tomato annexins p34 and p35 bind to F-actin and display nucleotide phosphodiesterase activity inhibited by phospholipid binding. Plant Cell. 8:333-342.

Cassab, G.I. 1998. Plant cell wall proteins. Annu. Rev. Plant Physiol. Plant Mol. Biol. 49: 281-309. 
Chiba, S., Miyanishi, M., Kondo, H. and Tamada, T. 2003. Single amino acid changes in the P25 protein gene of Beet necrotic yellow vein virus are involved in resistance responses in Beta vulgaris ssp. maritima. . 5th Symp. of the Int. Working Group of Plant Viruses with Fungal Vectors, Zürich, Schweiz.

Chiba, S., Miyanishi, M., Andika, I.B., Kondo, H. and Tamada, T. 2008. Identification of amino acids of the beet necrotic yellow vein virus p25 protein required for induction of the resistance response in leaves of Beta vulgaris plants. J. Gen. Virol. 89:1314-1323.

Cormack, R.S., Hahlbrock, K. and Somssich, I.E. 1998. Isolation of putative plant transcriptional coactivators using a modified two-hybrid system incorporating a GFP reporter gene. Plant J. 14:685-692.

Crameri, A., Whitehorn, E.A., Tate, E. and Stemmer, W.P.C. 1996. Improved green fluorescent protein by molecular evolution using DNA shuffling. Nat. Biotechnol. 14:315-319.

Dargeviciute, A., Roux, C., Decreux, A., Sitbon, F., and Perrot-Rechenmann, C. 1998. Molecular cloning and expression of the early auxin-responsive Aux/IAA gene family in Nicotiana tabacum. Plant Cell Physiol. 39:993-1002.

Dessens, J.T., and Meyer, M. 1996. Identification of structural similarities between putative transmission proteins of Polymyxa and Spongospora transmitted bymoviruses and furoviruses. Virus Genes 12:95-99.

Estojak, J., Brent, R., and Golemis, E.A. 1995. Correlation of 2-Hybrid Affinity Data with in-Vitro Measurements. Mol Cell Biol.5:5820-5829.

Fields, S., and Song, O.K. 1989. A Novel Genetic System to Detect Protein Protein Interactions. Nature 340:245-246. 
Gidner, S., Lennefors, B.L., Nilsson, N.O., Bensefelt, J., Johansson, E., Gyllenspetz, U., and Kraft, T. 2005. QTL mapping of BNYVV resistance from the WB41 source in sugar beet. Genome 48:279-285.

Gietz, R.D., and Woods, R.A. 2002. Transformation of yeast by lithium acetate/single-stranded carrier DNA/polyethylene glycol method. Methods Enzymol. 350:87-96.

Grimmer, M.K., Trybush, S., Hanley, S., Francis, S.A., Karp, A., and Asher, M.J.C. 2007. An anchored linkage map for sugar beet based on AFLP, SNP and RAPD markers and QTL mapping of a new source of resistance to Beet necrotic yellow vein virus. Theor Appl Genet. 114:1151-1160.

Guo, D., Spetz, C., Saarma, M., and, Valkonen ,J.P. 2003 Two potato proteins, including a novel RING finger protein (HIP1), interact with the potyviral multifunctional protein HCpro. Mol Plant Microbe Interact. 16:405-410.

Gyuris, J., Golemis, E., Chertkov, H., and Brent, R. 1993. Cdi1, a human G1 and S phase protein phosphatase that associates with Cdk2. Cell 75:791-803.

Hamilton, A.J., Voinnet, O., Chappell, L., and Baulcombe, D.C. 2002. Two classes of short interfering RNA in RNA silencing. EMBO J. 21:4671-4679.

Heijbroek, W., Musters, P.M.S., and Schoone, A.H.L. 1999. Variation in pathogenicity and multiplication of beet necrotic yellow vein virus (BNYVV) in relation to the resistance of sugar-beet cultivars. Europ.J. Plant Pathol 105:397-405.

Holstein, S.E.H. 2002. Clathrin and plant endocytosis. Traffic 3: 614-620.

Horvath, A., and Riezman, H. 1994. Rapid Protein Extraction from Saccharomyces-Cerevisiae. Yeast 10:1305-1310. 
Iwabuchi, K., Li, B., Bartel, P., and Fields, S. 1993. Use of the two-hybrid system to identify the domain of p53 involved in oligomerization. Oncogene 8:1693-1696.

Jach, G., Pesch, M., Richter, K., Frings, S., and Uhrig, J.F. 2006. An improved mRFP1 adds red to bimolecular fluorescence complementation. Nat Methods 3:597-600.

Jiménez, J.A., Rodriguez, D., Calvo, A.P., Mortensen, L.C., Nicolása, G., and Nicolás 2005. Expression of a transcription factor (FsERF1) involved in ethylene signalling during the breaking of dormancy in Fagus sylvatica seeds. Physiol Planta 125: 373-380.

Jin, Y., Ma, D., Dong, J., Jin, J., Li, D., Deng C., and Wang, T. 2007. HC-Pro protein of Potato virus $\mathrm{Y}$ can interact with three Arabidopsis $20 \mathrm{~S}$ proteasome subunits in planta. J Virol 81:12881-128888.

Johansson, E. 1985. Rizomania in sugar beet - a threat to beet growing that can be overcome by plant breeding. Sver. Utsädesfören. Tidsk 95:115-121.

Keskin, B. 1964. Polymyxa Betae Nsp Ein Parasit in Den Wurzeln Von Beta Vulgaris Tournefort Besonders Wahrend Der Jugendentwicklung Der Zuckerrube. Archiv Für Mikrobiologie 49:218-226

Klein, E., Link, D., Schirmer, A., Erhardt, M., and Gilmer, D. 2007. Sequence Variation within Beet necrotic yellow vein virus p25 protein influences its oligomerization and isolate pathogenicity on Tetragonia expansa. Virus Res 126:53-61.

Koenig, R. (2008). Benyviruses. In B. Mahy and M. van Regenmortel (ed.), Encyclopedia of virology, 3rd ed. Elsevier Ltd., Oxford, United Kingdom. 
Koenig, R., and Lesemann, D.E. 2005. Benyvirus. In: Fauquet CM, Mayo M, Maniloff J, Desselberger U, and Ball LA (eds.) Virus Taxonomy, VIII Report of the ICTV,. London: Academic Press:1043-1048.

Koenig, R., Haeberle, A.M., and Commandeur, U. 1997. Detection and characterization of a distinct type of beet necrotic yellow vein virus RNA 5 in a sugarbeet growing area in Europe. Arch Virol 142:1499-1504.

Koenig, R., Jarausch, W., Li, Y., Commandeur, U., Burgermeister, W., Gehrke, M., and Luddecke, P. 1991. Effect of Recombinant Beet Necrotic Yellow Vein Virus with Different Rna Compositions on Mechanically Inoculated SugarBeets. J Gen Virol 72:2243-2246.

Kole, C. 2007. Vegetables - Genome Mapping and Molecular Breeding in Plants, Vol. 5, Springer Verlag, Berlin Heidelberg, Germany.

Konopka-Postupolska D. 2007 Annexins: putative linkers in dynamic membranecytoskeleton interactions in plant cells. Protoplasma. 230: 203-215.

Larson, R.L., Wintermantel, W.M., Hill, A., Fortis, L., and Nunez, A. 2008. Proteome changes in sugar beet in response to Beet necrotic yellow vein virus. Physiol Mol Plant P 72:62-72.

Leubner-Metzger, G., Petruzzelli, L., Waldvogel, R., Vögeli-Lange, R., and Meins, F. Jr. 1998 Ethylene-responsive element binding protein (EREBP) expression and the transcriptional regulation of class I beta-1,3-glucanase during tobacco seed germination. Plant Mol Biol. 38:785-795.

Letunic, I., Copley, R.R., Pils, B., Pinkert, S., Schultz, J. and Bork, P. 2006 SMART 5: domains in the context of genomes and networks. Nucleic Acids Res, 34: 257-260 
Lewellen, R.T., Skoyen, I.O., and Erichsen, A.W. 1987. Breeding sugar beet for resistance to rhizomania: Evaluation of host-plant reactions and selection for and inheritance of resistance. Proc. 50th IIRB Congress Brussels, Belgium:139-156.

Li, X.B., Fan, X.P., Wang, X.L., Cai, L., and Yang, W.C. 2005 The cotton ACTIN1 gene is functionally expressed in fibers and participates in fiber elongation. Plant Cell. 17:859-875.

Li, B., and Fields, S. 1993. Identification of Mutations in P53 That Affect Its Binding to Sv40 Large T-Antigen by Using the Yeast 2-Hybrid System. Faseb J 7:957-963.

Link, D., Schmidlin, L., Schirmer, A., Klein, E., Erhardt, M., Geldreich, A., Lemaire, O., and Gilmer, D. 2005. Functional characterization of the Beet necrotic yellow vein virus RNA-5-encoded p26 protein: evidence for structural pathogenicity determinants. J Gen Virol 86:2115-2125.

Liu, H.Y., and Lewellen, R.T. 2007. Distribution and molecular characterization of resistance-breaking isolates of Beet necrotic yellow vein virus in the United States. Plant Dis 91:847-851.

Liu, H.Y., Sears, J.L., and Lewellen, R.T. 2005. Occurrence of resistance-breaking Beet necrotic yellow vein virus of sugar beet. Plant Dis 89:464-468.

Luterbacher, M.C., Asher, M.J.C., Beyer, W., Mandolino, G., Scholten, O.E., Frese, L., Biancardi, E., Stevanato, P., Mechelke, W., and Slyvchenko, O. 2005. Sources of resistance to diseases of sugar beet in related Beta germplasm: II. Soil-borne diseases. Euphytica 141:49-63.

Merkouropoulos, G., and Shirsat, A.H. 2003. The unusual Arabidopsis extensin gene atExt1 is expressed throughout plant development and is induced by a variety of biotic and abiotic stresses. Planta 217:356-366. 
Merkouropoulos, G., Barnett, D.C., and Shirsat, A.H. 1999. The Arabidopsis extensin gene is developmentally regulated, is induced by wounding, methyl jasmonate, abscisic and salicylic acid, and codes for a protein with unusual motifs. Planta 208:212-219.

Miyanishi, M., Kusume, T., Saito, M., and Tamada, T. 1999. Evidence for three groups of sequence variants of beet necrotic yellow vein virus RNA 5. Arch Virol 144:879-892.

Pazhouhandeh M., Dieterle M., Marrocco K., Lechner E., Berry B., Brault V., Hemmer O., Kretsch T., Richards K.E., Genschik P., and Ziegler-Graff V. 2006. F-box-like domain in the polerovirus protein $P 0$ is required for silencing suppressor function. Proc Natl Acad Sci U S A. 103:1994-1999.

Pérez-Gómez , J., and Moore, I. 2007 Plant endocytosis: it is clathrin after all. Curr Biol. 17: 217-9.

Pferdmenges, F., Korf, K., and Varrelmann, M. 2008. Identification of rhizomaniainfected soil in Europe able to overcome Rz1 resistance in sugar beet and comparison with other resistance-breaking soils from different geographic origins. European Journal of Plant Pathology DOI 10.1007/s10658-0089388-9

Pollini, C.P., and Giunchedi, L. 1989. Comparative histopathology of sugar beets that are susceptible and partially resistant to rhizomania. Phytopathol Mediterr 28:16-21.

Pollini, C.P., Masia, A., and Giunchedi, L. 1990. Free indole-3-acetic acid in sugarbeet root of rhizomania-susceptible and moderately resistant cultivars. Phytopathol Mediter 29:191-195. 
Rahim, M.D., Andika, I.B., Han, C., Kondo, H. and Tamada, T. 2007. RNA4Encoded P31 of Beet Necrotic Yellow Vein Virus Is Involved in Efficient Vector Transmission, Symptom Severity and Silencing Suppression in Roots. J Gen Virol 88: 1611-1619.

Reichel, C., and Beachy, R.N. 2000. Degradation of tobacco mosaic virus movement protein by the $26 \mathrm{~S}$ proteasome. J Virol. 74:3330-3337.

Richard-Molard, M. 1985. Rhizomania: a world-wide danger to sugar beet. Span 28:92-94.

Richard-Molard, M.S., and Cariolle, M. 2001. Stress hydrique et abiotique et amélioration genetique. Proc. 64th IIRB Congress, Bruges, Belgium, 153158.

Rush, C.M. 2003. Ecology and epidemiology of Benyviruses and plasmodiophorid vectors. Annu Rev of Phytopathol 41:567-592.

Sambrook, J., and Russell, D.W. 2001. Molecular Cloning: A Laboratory Manual. Cold Spring Harbor Laboratory Press, Cold; Spring Harbor, NY, 3rd Edition.

Sambrook, J., Fritsch, E.F., and Maniatis, T., eds. 1989. Molecular Cloning: A Laboratory Manual. Cold Spring Harbor Laboratory, Cold Spring Harbor, NY, U.S.A.

Schirmer, A., Link, D., Cognat, V., Moury, B., Beuve, M., Meunier, A., Bragard, C., Gilmer, D., and Lemaire, O. 2005. Phylogenotic analysis of isolates of Beet necrotic yellow vein virus collected worldwide. J Gen Virol 86:2897-2911.

Schmidlin, L., Link, D., Mutterer, J., Guilley, H., and Gilmer, D. 2005. Use of a Beet necrotic yellow vein virus RNA-5-derived replicon as a new tool for gene expression. J Gen Virol 86:463-467. 
Schmidlin, L., de Bruyne, E., Weyens, G., Lefebvre, M., and Gilmer, D. 2008. Identification of differentially expressed root genes upon rhizomania disease. Mol plant pathol 9. 741-51

Scholten, O.E., and Lange, W. 2000. Breeding for resistance to rhizomania in sugar beet: A review. Euphytica 112:219-231.

Scholten, O.E., De Bock, T.S.M., Klein-Lankhorst, R.M., and Lange, W. 1999. Inheritance of resistance to beet necrotic yellow vein virus in Beta vulgaris conferred by a second gene for resistance. Theor Appl Genet 99:740-746.

Scholten, O.E., Paul, H., Peters, D., Vanlent, J.W.M., and Goldbach, R.W. 1994. In-Situ Localization of Beet Necrotic Yellow Vein Virus (Bnyvv) in Rootlets of Susceptible and Resistant Beet Plants. Arch Virol 136:349-361.

Soellick, T.R., and Uhrig, J.F. 2001. Development of an optimized interactionmating protocol for large-scale yeast two-hybrid analyses. Genome Biol 2:RESEARCH0052.

Soellick T, Uhrig J.F., Bucher G.L., Kellmann J.W., and Schreier P.H. 2000. The movement protein NSm of tomato spotted wilt tospovirus (TSWV): RNA binding, interaction with the TSWV N protein, and identification of interacting plant proteins. Proc Natl Acad Sci U S A. 97:2373-2378.

Schultz, J., Milpetz, F., Bork, P., and Ponting, C.P.1998 SMART, a simple modular architecture research tool: identification of signaling domains.Proc Natl Acad Sci U S A. 95:5857-5864.

Takemoto, D., Doke, N., and Kawakita, K. 2001. Characterization of elicitorinducible tobacco genes isolated by differential hybridization. J Gen Plant Pathol 67 89-96. 
Tamada, T. 1999. Benyvirus. In: Granoff, A.; Webster, R. (Hrsg.) Encyclopedia of Virology. Academic Press, New York:154-160.

Tamada, T. 2007. Susceptibility and resistance of Beta vulgaris subsp. maritima to foliar rub-inoculation with Beet necrotic yellow vein virus. J of Gen Plant Pathol 73:76-80.

Tamada, T., and Baba, T. 1973. Beet necrotic yellow vein virus from rhizomania affectedsugar beet in Japan. Annual Phytopath. Soc. Japan 39:325-332.

Tamada, T., Kusume, T., Uchino, H., Kiguchi, T., and Saito, M. 1996a. Evidence that beet necrotic yellow vein virus RNA-5 is involved in symptom development of sugar-beet roots. Proc. 3rd Symp. of the Int. Working Group on Plant Viruses with Fungal Vectors, Dundee (UK):49-52.

Tamada, T., Kusume, T., Uchino, H., Kiguchi, T., and Saito, M. 1996b. Evidence that beet necrotic yellow vein virus RNA-5 is involved in symptom development of sugar-beet roots. . In: Sherwood, J.L.; Rush, C.M. (Hrsg.). Proc. 3rd Symp. of the Int. Working Group on Plant Viruses with Fungal Vectors, Dundee (UK):49-52.

Tamada, T., Miyanishi, M., Kondo, H., Chiba, S., and Han, C.G. 2003. Pathogenicity and molecular variability of Beet necrotic yellow vein virus isolates from Europe, Japan, China, and the United States. 5th Symp. of the Int. Working Group of Plant Viruses with Fungal Vectors, Zürich, Schweiz (2002).

Tamada, T., Shirako, Y., Abe, H., Saito, M., Kiguchi, T., and Harada, T. 1989. Production and pathogenisity of isolates of Beet necrotic yellow vein virus with different numbers of RNA components. J Gen Virol 70:3399-3409. 
Vancanneyt, G., Schmidt, R., O'Connor-Sanchez, A., Willmitzer, L., and RochaSosa, M. 1990. Construction of an intron-containing marker gene: splicing of the intron in transgenic plants and its use in monitoring early events in Agrobacterium-mediated plant transformation. Mol Gen Genet 220:245-250.

Varrelmann, M., Maiss, E., Pilot, R., and Palkovics, L. 2007. Use of pentapeptideinsertion scanning mutagenesis for functional mapping of the plum pox virus helper component proteinase suppressor of gene silencing. J Gen Virol 88:1005-1015.

Vetter, G., Hily, J.M., Klein, E., Schmidlin, L., Haas, M., Merkle, T., and Gilmer, D. 2004. Nucleo-cytoplasmic shuttling of the beet necrotic yellow vein virus RNA-3-encoded p25 protein. J Gen Virol 85:2459-2469.

Voinnet, O., Rivas, S., Mestre, P., and Baulcombe, D. 2003. An enhanced transient expression system in plants based on suppression of gene silencing by the $\mathrm{p} 19$ protein of tomato bushy stunt virus. Plant $\mathrm{J}$ 33:949956.

Walter, M., Chaban, C., Schutze, K., Batistic, O., Weckermann, K., Nake, C., Blazevic, D., Grefen, C., Schumacher, K., Oecking, C., Harter, K., and Kudla, J. 2004. Visualization of protein interactions in living plant cells using bimolecular fluorescence complementation. Plant J 40:428-438.

Ward, L., Koenig, R., Budge, G., Garrido, C., McGrath, C., Stubbley, H., and Boonham, N. 2007. Occurrence of two different types of RNA-5-containing beet necrotic yellow vein virus in the UK. Arch Virol 152:59-73.

Whitney, E.D. 1989. Identification, Distribution, and Testing for Resistance to Rhizomania in Beta-Maritima. Plant Dis 73:287-290. 
Yilmaz, N.D.K., Meunier, A., Schmit, J.F., Stas, A., and Bragard, C. 2007. Partial nucleotide sequence analysis of Turkish isolates of Beet necrotic yellow vein virus (BNYVV) RNA-3. Plant Pathology 56:311-316. 


\section{Kapitel 4: Beet necrotic yellow vein virus P25 pathogenicity factor interacts with a sugar beet F-box protein from resistant and susceptible genotypes involved in the induction of a hypersensitive resistance response}

Manuscript submitted to Journal of Virology

Heike Thiel $^{1 \dagger}$, Kamal Hleibieh ${ }^{2 \dagger}$, David Gilmer $^{2}$ and Mark Varrelmann ${ }^{3}$

${ }^{1}$ Department of Crop Sciences, Section Plant Virology, University of Göttingen, Grisebachstrasse 6, D37077 Göttingen, Germany

${ }^{2}$ Institut de Biologie Moléculaire des Plantes, laboratoire propre du CNRS (UPR 2357) conventionné avec l’Université Louis Pasteur (Strasbourg 1), 12 rue du Général Zimmer, 67084 Strasbourg, France

${ }^{\dagger}$ Both authors contributed equally to this paper.

Author for correspondence: Mark Varrelmann

e-mail: varrelmann@ifz-goettingen.de

Key words: Benyvirus, avirulence gene, virus resistance, hypersensitive resistance, rhizomania, Beta vulgaris

\section{ABSTRACT}

We have previously identified a putative F-box protein from $R z 2$ sugar beet capable of physically interacting with the beet necrotic yellow vein virus (BNYVV) RNA3-encoded P25 pathogenicity factor in LexA yeast two-hybrid (YTH) cDNA-library screen. This interaction was confirmed here with both GAL4-YTH system and in an in vitro pull-down assay and turned out to be independent of P25's amino acid 67-70 tetrad composition that varies between BNYVV isolates. The identity of the cDNA F-box was confirmed by detecting the interaction with Arabidopsis thaliana SKP1 orthologs using YTH. Full-length F-box clones issued from two BNYVV resistant and one susceptible sugar beet lines still interacted with P25 suggesting a resistance independent P25-F-box interaction. F-box transient agrobacterium mediated expression in Nicotiana benthamiana leaves 
induced necrosis and increased transcript levels of pathogenesis-related proteins, indicating the involvement of the F-box protein in a stress or hypersensitive response to pathogens. F-box proteins belong to an SCF-complex (SKP1-Cullin1F-box) and provide substrate specificity via their C-terminal domain for the SCF ubiquitin ligases in the protein ubiquitinylation and $26 \mathrm{~S}$ proteasome protein degradation. The full-length F-box candidates consist of one F-box domain followed by two kelch motifs. These two domains were tested separately for P25 interaction and necrosis induction. Neither interaction with P25 nor cell-death was induced by F-box or kelch domain, pinpointing the entire F-box protein to be necessary for P25 interaction and cell-death induction. The observed P25-F-box interaction suggests a possible involvement in the BNYVV pathogenicity or suppression of resistance response in sugar beet.

\section{INTRODUCTION}

BNYVV, type species of the genus Benyvirus, possesses a four to five plus sense RNA genome and is vectored by the soil-borne plasmodiophoromycete Polymyxa betae (22). In susceptible sugar beet genotypes, BNYVV causes rhizomania symptoms that consist of extensive root proliferation of the taproot to form additional necrotising hair-roots and induces tap-root discoloration. Typical rhizomania symptoms occur only in the presence of RNA3 encoded P25 $(26,54)$. P25 and its composition, is associated with the resistance response and formation of necrotic lesions in mechanical inoculated leaves of Beta vulgaris and B. maritima $(6,25,52)$. Chiba and co-workers (6) suggested P25 to function as an avirulence (Avr) gene product in resistant and pathogenicity factor in susceptible genotypes. P25 is a nucleo-cytoplasmic shuttling protein and its subcellular localization determines symptom severity on the local lesion host Chenopodium quinoa (57).

Due to the severe disease symptoms generated by BNYVV, high yielding sugar beet production is only reliable by growth of resistant cultivars. The USAmerican Holly Sugar Company identified an important major dominant resistance gene $R z 1$, also known as 'Holly' source $(3,47,48)$. Further resistance sources from wild beet (B. vulgaris ssp. maritima) accessions contain the 
resistance genes $R z 3$ (WB41) and $R z 2$ (WB42), respectively (47, 49, 62). Recently, a hybrid line named R36 permitted the identification of a fourth resistance gene named $R z 4$ (12). However, the underlying mechanisms of all resistance sources ( $R z 1, R z 2, R z 3$ and $R z 4)$ mediating a quantitative resistance are unknown. Rz-carrying plants do not possess resistance to infection but display reduced virus titers and restricted systemic virus spread $(17,36,49,53)$.

The P25 avirulence gene - pathogenicity factor hypothesis is supported by the coincidence of the occurrence of Rz1 overcoming BNYVV isolates from several locations in the USA and Europe $(34,35,38)$ with P25 proteins harbouring specific mutations in the amino acid hypervariable tetrad 67-70 (46). In a previous YTH screen of an Rz2-resistant sugar beet cDNA library with P25, representing an incompatible host virus interaction, we identified several candidates and confirmed some yeast interactions using in planta bimolecular fluorescence complementation assay (BiFC) (Thiel and Varrelmann, submitted for publication). One cDNA encoded candidate displayed significant homology to $A$. thaliana kelch repeat containing F-box family protein. Interestingly agrobacterium mediated transient expression of this F-box candidate in BiFC assay induced an early and rapid leaf tissue necrosis in $N$. benthamiana 24 hours post infiltration (hpi). F-box proteins are involved in the ubiquitin-proteasome-system (UPS). Ubiquitylation of proteins intended for degradation by the $26 \mathrm{~S}$ proteasome is carried out by the activity of three protein enzymatic complexes named ubiquitinactivating enzyme E1, ubiquitin-conjugating E2 and ubiquitin-ligase E3 (18). Subsequent to activation and conjugation of proteins by the E1 and E2 enzymes, E3 ligase is necessary to recruit the specific target protein recognized for destruction to the $26 \mathrm{~S}$ proteasome (13). The E3 ligase is responsible for substrate specificity and can be divided in different E3 classes (HECT homologous to E6-associated, APC - anaphase promoting complex, Ring/U-box and SCF) (59). The SCF complex is characterized as a crucial type of ubiquitin E3 ligase and consists of four major components SKP1, Cul1, Rbx1 and an F-box protein $(5,19,30)$. F-box proteins display a common architecture sequence motif which was initially described by Bai et al. (1). In addition to the N-terminal F-box motif which binds SKP1, a typical protein-protein interaction domain (e.g. leucinerich repeats or kelch-repeats) for substrate specific binding to the SCF complex is 
localized in the C-terminus $(24,30)$. The F-box candidate with homology to $A$. thaliana F-box (Acc. no. NM_126342.3) identified in our study, contains two C-terminal kelch repeats. Kelch domains were initially discovered in Drosophila melanogaster $(4,63)$. In addition, two other P25 interacting proteins identified previously displayed high homology to $A$. thaliana proteins involved in the ubiquitylation process namely another kelch repeat-containing F-box family protein (Acc. no. NM_102054.3) and one U-box (PUB17) (Acc. no. NM_102674.3). Recent work identified F-box proteins as one of the largest protein families in plants. In $A$. thaliana model plant, nearly 700 different F-box protein encoding genes have been predicted (30). They connect the ubiquitylation machinery to many cellular processes by regulating the stability of substrate proteins like transcription factors involved in e.g. phytohormone signaling, light signaling and lateral root formation $(10,27,30)$. In addition to developmental processes, F-box proteins as part of the E3 ligase complex SCF have been described in several studies to be involved in the plants resistance response to infection with pathogens. Involvements of F-box in the well-characterized defense mechanisms induced by a hypersensitive response (HR), the systemic acquired resistance (SAR) can be exemplified by $A$. thaliana. SON1, an F-box protein involved in targeting SAR regulators to protein degradation (23). In tobacco, the F-box protein ACRE189 is necessary for the plant hypersensitive response to Cladiosporum fulvum Avr9 (56). In consequence to these two studies and our observation that transient overexpression of P25 interacting sugar beet F-box candidate induced necrosis in $N$. benthamiana leaf tissue, we raised the hypothesis that the F-box candidate might be either involved in the sugar beet resistance against BNYVV or alternatively, represents a target of P25 necessary for viral pathogenicity. The targets of both F-box candidate homologues from Arabidopsis have not been identified yet and prediction of putative function remained impossible due to the wide involvement of F-box proteins in different cellular processes.

In this study, the LexA-based YTH P25-F-box interaction was reinvestigated with GAL4 transcriptional activation domain in yeast and via an in vitro pull-down assay. In addition, YTH interaction studies with plant SCF components were applied to find evidence for the F-box identity of the candidate. 
To support the HR hypothesis, transcriptional activation of pathogenesis related protein (PR-proteins) expression following transient expression in $N$. benthamiana was investigated. Full-length homologues from one rhizomania susceptible and two resistant ( $R z 1$ and $R z 2)$ sugar beet homozygous genotypes were isolated and applied for P25 interaction analysis. Finally both conserved functional domains (F-box and kelch) were separated and both tested for their interaction with P25 and for the necrosis induction in agroinfiltrated plants.

\section{MATERIAL AND METHODS}

\section{Construction of F-box and P25 yeast expression vectors}

All cloning procedures and manipulations were performed following standard techniques according to Sambrook et al. (44), applied modifications were otherwise specified. The yeast vector pJG4-5 (MoBiTec) carrying the partial Fbox-cDNA-Rz2 encoding sequence inserted via EcoRI-Xhol (pJG4-5-F-boxcDNA) was obtained from a P25 YTH screen of a sugar beet (Rz2) cDNA library (Thiel and Varrelmann, submitted for publication). RT-PCR from total RNA of healthy sugar beet breeding lines (MS150 susceptible, MS298 Rz1 resistant, kindly supplied by Syngenta Seeds AB, Lanskrona, Sweden and 8T_0015 kindly supplied by KWS, Einbeck, Germany) with specific oligonucleotides (5'ATGAATTCTTGGAAGATCTTTCATTTGC-3' and 3'-ATCTCGAGTTAGCAGCCC ATTATTGCAC-5') led to amplification products which were cloned into pJG4-5. Resulting plasmids were named pJG4-5-F-box-susc., $-R z 1$ and $-R z 2$, respectively. To confirm cDNA-library F-box candidate P25 interaction in GAL4 YTH, F-Box-cDNA and P25 coding sequence were subcloned into plasmid pGAD424 (Clontech) using EcoRI and Sall. pGBT and pGAD-P25 vectors were described previously (25).

Construction of $R z 2$ derived F-box $\mathrm{N}$ - and C-terminal deletion mutants, expressing the $187 \mathrm{~N}$-terminal F-box domain-spanning amino acids (aa) and Cterminal 255 aa including the two kelch motifs was carried out as follows. Both $5^{\prime}$ $561 \mathrm{nt}$ and 3' $765 \mathrm{nt}$ fragments were amplified with the corresponding full-length primers (see above) together with specific oligonucleotides (5'-low 3'TATCTCGAGCTAAACCGCAAGTGACTCCTTATCC-5' and 3'-up: 
5'-ATGAATTCGGTACCGAACTTTTGGTCTTTG-3'). Both PCR fragments were cloned into pJG4-5, resulting in pJG4-5-F-box- $\Delta N$ and $-\Delta C$ respectively. The coding sequence of a P25 variant from an $R z 1$ resistance breaking isolate (Imperial Valley, Salinas USA) (35) was PCR amplified and cloned into pEG202 as described (Thiel and Varrelmann, submitted for publication)).

\section{Construction of binary vectors for transient in planta F-box expression}

All F-box full-length and F-box deletion mutant sequences described above were cloned under control of the CaMV $35 \mathrm{~S}$ promoter (35S) and pA signal into a binary vector pBin modified for direct subcloning with EcoRI and Xhol for transient agroexpression in N. benthamiana leaf tissue resulting in pBin-F-box-cDNA, susc., $-R z 1,-R z 2,-\Delta \mathrm{N}$ and $-\Delta \mathrm{C}$.

\section{Protein-protein interaction in vitro - GST pull-down assay}

Histidine tagged BNYVV B-type P25 was cloned into plasmid pIVEX ${ }^{\circledR} 2.3$ (In Vitro EXpression, Roche) and expressed by a rapid translation system (RTS100; Roche). Flag-P25 was produced in Sf9 insect cells infected with recombinant Baculovirus. F-box candidate CDNA PCR amplified with specific primers 5'-AAAGGATCCATGGAAGTCGATTTC-3' and 3'-AAAGAATTCTCAGTCCAAGT CCGTC-3' and the amplicon cloned into pGEX 2TK vector to obtain pGEX-F-box (Pharmacia Biotech) using BamHI and EcoRI. E. coli BL21-codon Plus (DE3)-RIL strain was used to express the GST fusion proteins (Stratagene). A fresh $5 \mathrm{ml}$ overnight culture of E.coli BL21(DE3)RIL carrying pGEX-2TK or pGEX-F-box was added to $50 \mathrm{ml}$ of LB-medium and the cultures were incubated and shaken for $1 \mathrm{~h}$ at $37^{\circ} \mathrm{C}$ for pGEX-2TK and for $1 \mathrm{~h}$ at $25^{\circ} \mathrm{C}$ for pGEX-F-box. Expression of GST or GST-F-box was induced by the addition of $0.2 \mathrm{mM}$ final IPTG for $4 \mathrm{hrs}$. Cells were harvested by centrifugation at $5,000 \mathrm{~g}$ for $10 \mathrm{~min}$ at $4^{\circ} \mathrm{C}$ and resuspended in $5 \mathrm{ml}$ of NET buffer (50 mM Tris- $\mathrm{HCl}$ [pH 7.5], $100 \mathrm{mM} \mathrm{NaCl}, 1 \mathrm{mM}$ EDTA, 0.5\% Nonidet P-40, $1 \mathrm{mM}$ dithiothreitol). The cells were disrupted by French Press and the lysates mixed with $60 \mu \mathrm{l}$ of glutathione-Sepharose 4B beads, previously washed and resuspended in NET buffer, and were incubated overnight at $4{ }^{\circ} \mathrm{C}$ with gentle shaking. The beads were then washed three times by short 
centrifugation and resuspended in $60 \mu \mathrm{l}$ of NET buffer. $10 \mu \mathrm{l}$ was analyzed in SDS-PAGE and judged by Coomassie staining. Beads and NET buffer $(25 \mu \mathrm{l})$ were mixed with $10 \mu \mathrm{l}$ of in vitro translation reaction mixture or flag-P25 protein and the volume completed to $400 \mu$ with BB buffer (50 mM tris-HCL 7.5, $100 \mathrm{mM}$ $\mathrm{NaCl}$ ), Reaction was first incubated for $1 \mathrm{~h}$ at room temperature and then overnight at $4^{\circ} \mathrm{C}$ with gentle shaking. The beads were then washed three times as described above but using BB buffer, resuspended in $40 \mu$ of dissociation buffer (28), boiled for $10 \mathrm{~min}$ and finally pelleted. Aliquots $(20 \mu \mathrm{l})$ of the supernatants were subjected to $12 \%$ SDS-PAGE, and the proteins were immunodetected using specific P25, histidine or flag antibodies.

YTH interaction assay of sugar beet F-box candidate with A. thaliana ASK1 andASK2

A. thaliana ASK2 (Acc. no. At5g42190) and ASK1 (Acc. no. At1g10940) were kindly provided by Dr. V. Ziegler-Graff (IBMP).

\section{Sequence analysis}

All inserts in clones were sequence verified using standard primers. Sequencing reactions were carried out by Eurofins MWG Operon, Martinsried or by Malek Alioua (IBMP) using a BigDye Terminator Sequencing kit (Applied Biosystems) and specific primers with a Hitachi 3100 Genetic AnalyzerApplied Biosystems).

Sequence alignments with ClustalW algorithms (55) and assembly of full-length F-box cDNA sequences were carried out using DNAstar Lasergene Software (GATC Biotech) In silico manipulations of plasmids and primer design were performed with VectorNTI software (Invitrogen). Identification of F-box functional domains was carried out using the "Simple Modular Architecture Research Tool" (SMART 5) $(31,50)$.

\section{Yeast strains, media and YTH systems}

Two different YTH systems were used in this study. The Grow'n'Glow YTH system (MoBiTec) is a modified version of the LexA/B42 YTH system (9). It consists of pEG202 as bait and pJG4-5 as prey vector (15) and an additional LexA-operator controlled GFP reporter plasmid pGNG1 (7). All yeast 
transformations, media preparations and mating procedures were carried out as described (Thiel and Varrelmann, submitted for publication)). Total area optical density analysis of GFP fluorescence was carried out by epifluorescence microscopy of yeast cells carried out Gel-Pro analyser software 6.0 (Media Cybernetics) (Thiel and Varrelmann, submitted for publication).

The GAL4 based YTH system (Clontech) consists of pGAD424 (Clontech) as bait and pGBT9/pGBKT7 as prey plasmids. The YTH procedures were performed by using the Matchmaker two-hybrid system based on the Yeast Protocol Handbook (BD Biosciences Clontech) and also as described (16, 25, 33, 51). HF7c strain was transformed with Gal4BD-p25 fusions (pGBT9, Clontech) and Gal4BD-ASK1 and -ASK2 (pGBKT7) whereas Y187 strain was transformed with bait plasmids (Gal4AD-P25 or -F-box fusions). Mating was used to obtain diploids expressing both fusion proteins. Interactions were identified by the ability of diploids to grow on minimal medium depleted with tryptophan, leucine and histidine and in the presence of $x$ - $\alpha$ gal or of 3-aminotriazole (AT) at 3, 5 or 10 $\mathrm{mM}$. The strength of the yeast interaction was quantified using $\beta$-galactosidase liquid culture assay with o-nitrophenyl $\beta$-D-galactopyranoside (ONPG) as substrate $\left(\mathrm{OD}_{420}\right)$ and displayed as $\beta$-galactosidase units as described in Yeast Protocols Handbook of Clontech.

\section{Immunodetection of LexA and haemagglutinin (HA) tagged proteins} in yeast

Protein extraction from yeast cells and immunodetection procedure was carried out as described (Thiel and Varrelmann, submitted for publication)) with some modifications. The protein samples were separated by $12 \%$ SDS-PAGE and electroblotted on nitrocellulose (Amersham) for LexA-detection or PVDF (Roche) membranes for HA-detection.

\section{Plant material and plant growth condidtions}

$N$. benthamiana plants were cultivated in a glasshouse with day length of $14 \mathrm{~h}$ at $22^{\circ} \mathrm{C}$ under continuous artificial light in a mixture of turf and sand $(1: 1)$. 
Transient expression following agroinfiltration and particle bombardment of F-box candidates

Binary vectors were mobilized into Agrobacterium tumefaciens strain C58C1 (pGV2260) and cultures were prepared for agroinfiltration essentially as described (61) with an $\mathrm{OD}_{600}$ adjusted to 1.0. The DsRed coding sequence (Clontech) under control of $35 \mathrm{~S}$ and pA (pe35-DsRed, original pDsRed-C1; Clontech) was applied for microprojectile co-bombardment with $\mathrm{pBin}-\mathrm{F}-\mathrm{box}-\mathrm{Rz2}$ and $\mathrm{pBin}$ on detached leaves of 4-5 weeks old $N$. benthamiana plants using a particle inflow gun (11). At 3 dpi 5 leaves of each treatment were rated for single epidermal cells displaying DsRed expression using epifluorescence microscopy (Leica DMR, http://www.leica.com/) with a DsRed filter (Emitter HQ 620/60, Beamsplitter Q 585 LP, and Exciter HQ 565/30). Dead cells were visualized by the autofluorescence they displayed using a GFP filter (Emitter D 510/40, Beamsplitter 425 DCLP and Exciter D 395/40). Photographs were taken using a Leica DFC camera, DFC300 FX.

\section{Detection of pathogenesis related protein transcripts}

Total RNA from $N$. benthamiana agroinfiltrated leaf tissue was prepared (RNeasy; Qiagen) and treated with DNase (RQ1; Promega). Primers specific for $N$. tabacum PR-1a (D90196), PR-1b (X05453) and PR-1c (X05454) (39) were applied for RT-PCR amplification of the $N$. benthamiana orthologues. As internal control the constitutively expressed translation elongation factor gene EF1a (AF120093) was used. Primers and PCR conditions were used according to (64).

\section{RESULTS}

Sequence analysis of BNYVV P25 interacting sugar beet Rz2 encoded F-box protein and confirmation of LeXA-YTH interaction with GAL4-YTH

Previously a cDNA clone with 1149 bp in length was identified in a LexA-YTH screen of an Rz2 resistant sugar beet cDNA library among others applying BNYVV P25 (B-type, aa ${ }^{67-70}$ AYHR) as a bait (Thiel and Varrelmann, submitted for publication). NCBI Genbank Blastn search revealed high homology (e-value: $1 \mathrm{e}^{-85}, 68 \%$ query coverage with $67 \%$ maximal identity) to a kelch repeat- 
containing F-box family protein from A. thaliana (NM_126342.3) and subsequent amino acid sequence analysis resulted in prediction of two kelch motifs (aa 131 to 174 and 175 to 222) with high significance and one N-terminal F-box domain (aa 37 to 77 ) with less homology $\left(5.45 \mathrm{e}^{+01}\right)$.

In order to strengthen the significance of the interaction detected in yeast applying LexA-binding domain (-BD) and activation domain (-AD) mediated transcriptional activation of reporter gene expression, GAL4-YTH interaction assay was additionally performed (Fig. 1a). The F-box coding sequence was fused to GAL4-AD (pGAD-F-box) and the interaction challenged with P25 fused to GAL4-BD [pGBT-P25; (25)]. Similar to the results obtained in LexA-YTH (Thiel and Varrelmann, submitted for publication)) no transcriptional autoactivation was induced by both proteins, when empty GAL4-BD vectors (pGBT9 and pGBTKT7) were applied (Fig. 1a, left). The oligomerization of P25 (25) was retrieved (Fig. 1a, middle), as well as the P25-F-box interaction (Fig. 1a, right). Both interactions were detected in the presence of up to $5 \mathrm{mM}$ of the competitive inhibitor (3-aminotriazole; AT) that prevents self-activation of the reporter gene. The GAL4-YTH positive control (Clontech) consisted of the SV40 large T-antigen (LTA) fused to GAL4-AD (pTD1) (32) and murine P53 sequence fused to GAL4BD (pVA3) (20). Quantification of $\beta$-galactosidase ( $\beta$-gal) activity for estimating the strength of the P25-F-box interaction resulted in a mean of $16 \beta$-gal Miller units significantly two times higher than the P53-LTA control (Fig. 1b). The oligomerization of the P25 protein that did not give significant activation of the $\beta$-gal reporter gene can be explained by the growth of yeasts in interaction nonselective conditions. 
(a)

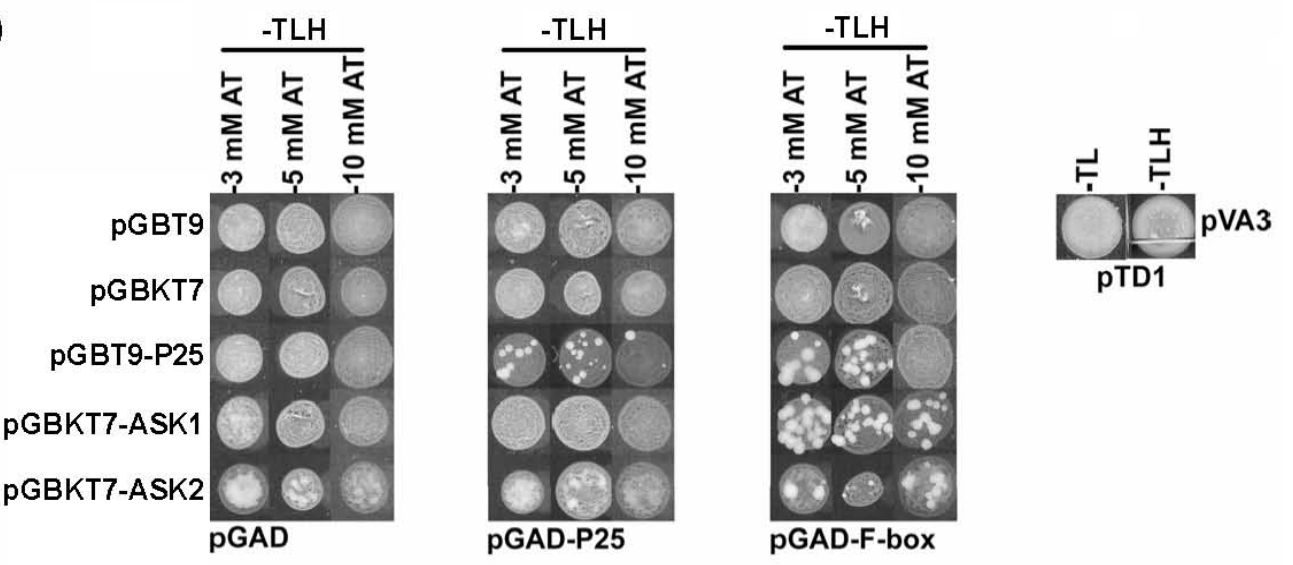

(b)

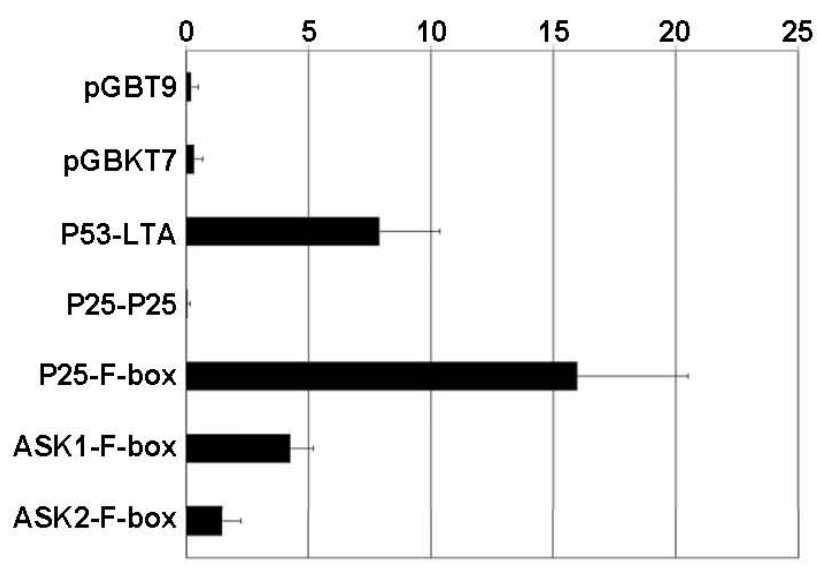

Figure 1. (a) GAL4-based yeast two-hybrid (YTH) interaction studies of beet necrotic yellow vein virus P25 (pGAD424- and pGBT9-P25), sugar beet F-box candidate (pGAD424-F-box-cDNA) and A. thaliana ASK1 and ASK2 (pGBKT7ASK1 and -ASK2). YTH interaction assay of the expression constructs of interest with empty vectors (pGBT9, pGBKT7 and pGAD424) to test for autoactivation. YTH interaction assay was controlled with P53 (pVA3) and LTA (pTD1) as positive control. YTH was carried out in the presence of 3, 5 and $10 \mathrm{mM} 3-$ aminotriazole (AT) to suppress background growth on selective media lacking amino acids tryptophane, leucine and histidine (-TLH). (b) Quantification of $\beta$-galactosidase ( $\beta$-gal) activity in Miller units of yeast diploids expressing the interaction partners grown under interaction-nonselective condidions in liquid culture assay at $30^{\circ} \mathrm{C}$. Assays were performed in triplicate sets with 3 independent cultures for each strain. 
Interaction of BNYVV P25 with sugar beet F-box protein is independent of the P25 amino acid tetrad 67-70 composition

BNYVV A-type isolates from Imperial Valley (IV) (California, USA) with a special composition of the $\mathrm{P} 25$ pathogenicity factor hypervariable amino acid tetrad 67-70 $\left({ }_{67} \mathrm{VLHG}_{70}\right.$ ) compared to the BNYVV B-type derived P25 ( ${ }_{77} A L H G_{70}$ ) have been shown to produce rhizomania symptoms and increased virus concentrations in resistant sugar beet cultivars $(35,38)$. We wanted to investigate if P25-F-box interactions are dependent on the P25 hypervariable sequence, which was shown to influence its oligomerization (25). The P25 coding sequence from an Imperial Valley (IV) field isolate was RT-PCR amplified with specific primers from sugar beet roots grown in a soil sample containing the resistant breaking strain BNYVVIV (kindly provided by Syngenta Seeds AB, Landskrona), cloned (pEG202-P25IV) and sequenced to confirm the presence of the ${ }_{67} \mathrm{VLHG}_{70}$ tetrad. Similarly to P25-B (67 $\mathrm{AYHR}_{70}$ ), P25-IV ( $\left.{ }_{67} \mathrm{VLHG}_{70}\right)$ i) did not autoactivate transcription in yeast (Fig. 2a) and ii) was able to interact with F-box-cDNA candidate at comparable strength (Fig. 2b and c).

(a)

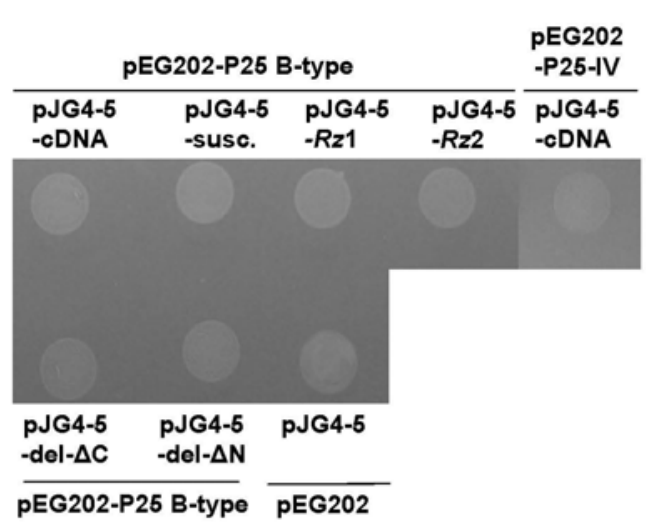

(b)

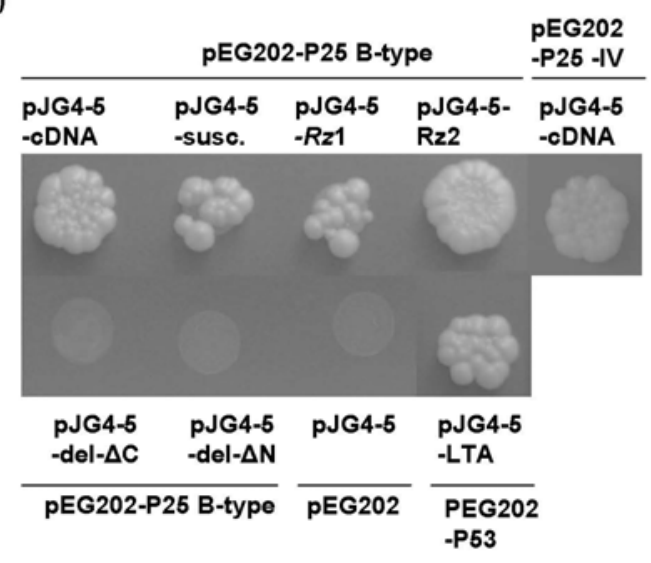




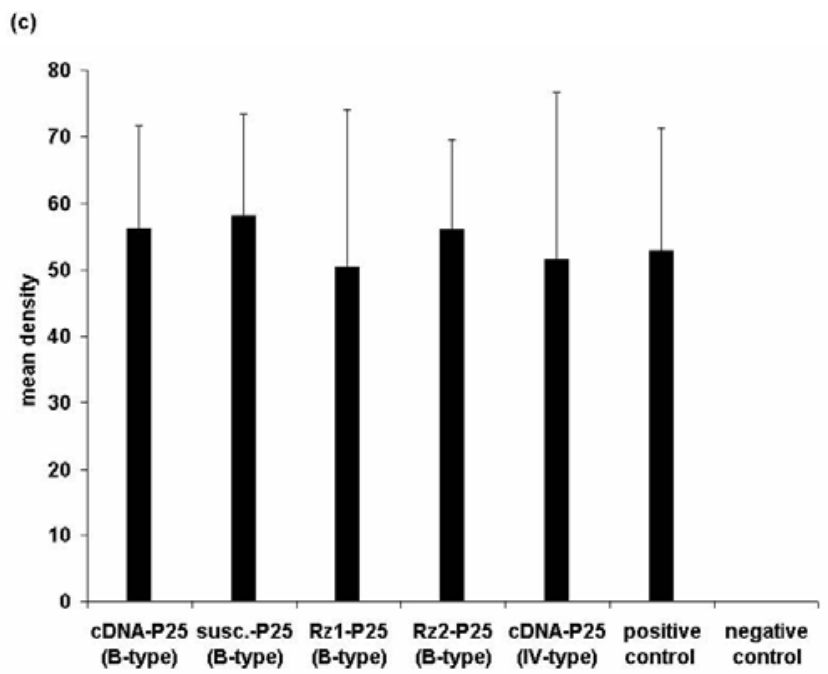

Figure 2. LexA-YTH interaction assay of BNYVV P25-B-type and Imperial Valley (-IV) origin with sugar beet F-box proteins (encoded by Rz2-cDNA, Rz1-, Rz2and susceptible-full-length clones as well as $R z 2 \mathrm{~N}$ - and C-terminal deletion mutants). The bait and prey combinations, co-transformed into yeast, were selected on medium containing galactose and lacking -Leu, -Trp, -Ura and -His.

(a) Test for transcriptional autoactivation of the -Leu reporter: pEG202 cotransformed with pJG4-5 expressing F-box variants (pJG4-5-cDNA, -susc., -Rz1, $-R z 2,-\Delta N,-\Delta C$ and pJG4-5), (b) Specific interactions of P25 (pEG202-P25-Btype) with different F-box proteins (pJG4-5-cDNA, -susc., $-R z 1,-R z 2,-\Delta N,-\Delta C$ ), P25-IV (pEG202-P25-IV) interaction with pJG4-5-F-box-cDNA, empty vectors pJG4-5 with pEG202 and positive control SV40 LTA (pJG4-5-LTA) with P53 (pEG202-P53).

(c) Relative quantification of Leu-driven GFP fluorescence in yeast cell matings expressing the same P25 and F-box variants as in (a) measured by displaying total area densities.

\section{Sugar beet cDNA encoded F-box candidate interacts with BNYVV P25}

\section{in vitro}

In order to definitely confirm the F-box P25 interaction, we performed an in vitro pull-down assay using GST-tagged F-box expressed in E. coli. Wild-type histidine tagged P25 expressed in E. coli lysate using a rapid translation system (RTS100, Roche) or Flag-P25 expressed in a baculovirus/insect system were used as probes. As negative and positive controls, we respectively used unfused GST or 
GST fused to the Rice importin- $\alpha$ P25 interactor (57). The analysis were conducted and the P25 was similarly immunodetected by the use of either antiP25, anti-histidine antibodies (data not shown) or Flag antibody only on GST-Imp$\alpha$ and GST-F-box fusion proteins (Fig. 3) confirming that F-box protein was indeed a partner of the $\mathrm{P} 25$ protein.

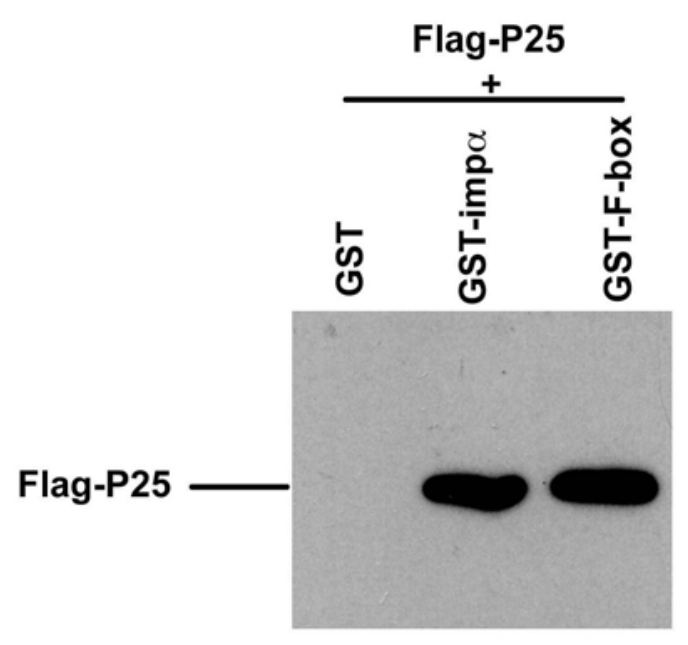

Figure 3. In vitro pull-down assays to confirm P25 interaction with F-box. FlagP25 from Baculovirus-infected Sf9 cells was incubated with GST alone, GSTimportin a (Rice) and GST-F-box. GST pull-down of P25 was visualized by the detection of the viral protein using flag antibody after immunoblotting. Reactions performed with in vitro synthesize histidin-tagged P25 gave identical results (data not shown).

The F-box candidate interacts with $A$. thaliana SKP1-related protein (ASK1) and ASK2 in yeast

If the candidate identified would represent an F-box protein, it should physically interact with plant subunits of the SCF complex as shown in different studies applying several F-box proteins (43). A. thaliana ASK1 (At1g10940) and ASK2 (At5g42190) fused to GAL4-BD in pGBTKT7-ASK1 and -ASK2 vectors respectively (37) were used for YTH interaction study with the F-box candidate (pGAD-F-box) (Fig. 1a). The absence or a weak transcriptional autoactivation were observed respectively for BD-ASK1 and -ASK2 fusion proteins (Fig. 1a, left). These two components of the SCF complex were not able to interact with P25 
(Fig. 1a, middle) but with the F-box even in the presence of $10 \mathrm{mM}$ AT (Fig. 1a, right). The interaction assay, however, revealed a lower strength interaction as compared to the F-box-P25 assay (Fig. 1b) presumably due to the growth of yeast in interaction non-selective medium.

\section{P25 interacts with sugar beet full-length F-box from Rz1, Rz2} resistant and susceptible sugar beet breeding lines

The $R z 2$ derived cDNA encoded F-box protein displayed typical conserved domains of F-box proteins (one F-box and two kelch repeats) and a stop-codon, however, its $5^{\prime}$-end sequence was not included in the cDNA clone. The questions remained, if i) interaction could be reproduced with full-length sequences and if ii) BNYVV encoded P25 interacts as well with the F-box proteins from $R z 1$ and susceptible sugar beet genotype (if existent). Sequence alignment between sugar beet EST sequence (genotype KWS2320 kindly provided by KWS, Einbeck Germany) and the identified sugar beet cDNA-F-box sequence identified the missing 5 '-end of the sequence required to complete the F-box open reading frame (data not shown). The translated full-length protein sequence was 34 $\mathrm{N}$-terminal amino acids longer than the cDNA encoded F-box candidate.

The sequence contig was used for the design of specific primers, which allowed successful RT-PCR amplification of different full-length F-box clones from susceptible and resistant $(R z 1, R z 2)$ sugar beet homozygous lines. All three PCR fragments were cloned in fusion with B42-AD (pJG4-5-F-box-Rz1, -Rz2, susceptible) and sequenced. The F-box open reading frame displayed a length of $1257 \mathrm{bp}$ for all three genotypes.

Sequence comparison of the three full-length clones on amino acid level resulted in the detection of a total of eight exchanges, three aa-exchanges between susceptible and $R z 1$, three aa-exchanges between $R z 1$ and $R z 2$ and two aa-exchanges between $R z 2$ and susceptible (data not shown).

LexA-YTH interaction studies of P25 (pEG202-P25) with F-box-cDNA clone (pJG4-5-F-box) were repeated and carried out with all three full-length clones. Yeast expression (Fig. 4a) as well as physical interaction was confirmed in all three cases (Fig. 2b). Remarkably but unexplained, the expression level of all full-length F-box proteins was much lower than those displayed by the cDNA 
encoded incomplete variant. The strength of the P25-F-box interaction was determined indirectly by quantification of the Leu-driven GFP expression relative to a negative ( $p E G 202-P 25, p J G 4-5$ ) and in comparison to the P53-LTA positive control (pEG202-P53, pJG4-5-LTA). As shown in Fig. 2c, no significant differences in interaction strength were detectable between the different alleles.

(a)

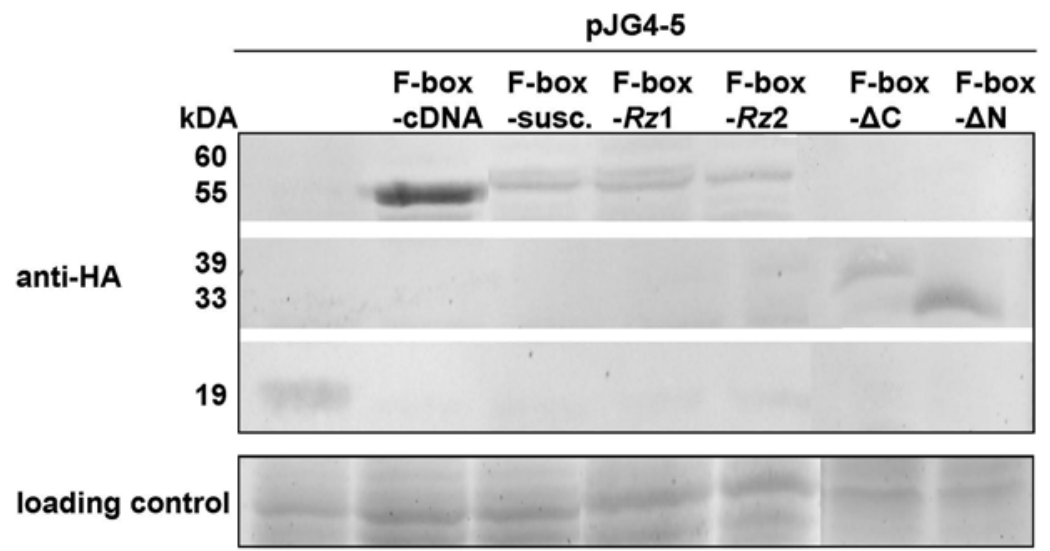

(b)

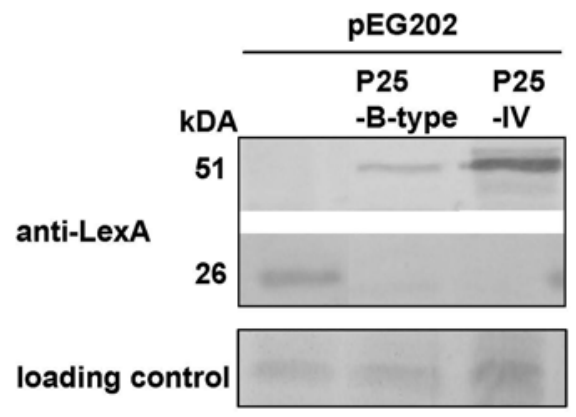

Figure 4. Immunodetection of LexA and haemagglutinin (HA) tagged proteins (anti-LexA and -HA). Equal PAGE loading was checked by staining. The molecular weights are declared in kilodalton $(\mathrm{KDa})$ (a) $\mathrm{HA}$ immunodetection in yeast total protein extracts expressing pJG4-5-F-box-cDNA, -F-box-susc., -F-box$R z 1,-F-b o x-R z 2,-F-b o x-\Delta N$, -F-box- $\Delta$ C. pJG4-5 served as control. (b) LexA immunodetection in yeast total protein extracts expressing pEG202-P25-B-type, P25-Imperial Valley (IV). pEG202 served as control. 


\section{P25 interacting F-box protein from resistant and susceptible} genotypes induce necrosis in $\boldsymbol{N}$. benthamiana leaves

Previously P25 open reading frame (ORF) and F-box cDNA were cloned into binary vectors for agrobacterium mediated BiFC. When they were used for transient expression in $N$. benthamiana leaf tissue to confirm the yeast interaction in planta, the F-box candidate induced necrosis (Thiel and Varrelmann, submitted for publication). Due to the speed by which it occurred, the necrosis resembled a hypersensitive resistance reaction.

To confirm that the F-box candidate alone and not the translational fluorescent marker-F-box fusion was responsible for the observed effect, F-boxcDNA candidate and all three F-box full-length sequences were cloned into binary vector $\mathrm{pBin}$ under control of cauliflower mosaic virus (CaMV) $35 \mathrm{~S}$ promoter and polyadenylation signal (pA) (pBin-F-box, -F-box-susceptible, -F-box-Rz1 and -Fbox-Rz2). Subsequent agroinfiltration exactly reproduced a necrotic reaction already starting to develop at $24 \mathrm{hpi}$ in all F-box treatments but not when the empty vector was applied. Fig. 5 shows $N$. benthamiana leaves at 3 dpi following treatment with $\mathrm{pBin}$ and $\mathrm{pBin}-\mathrm{F}-\mathrm{box}-\mathrm{Rz} 2$. In order to verify if P25 interferes with the induction of necrosis, it was used for co-infiltration with F-box- $R z 2$, resulting in no visible difference in time of occurrence and severity of the necrotic reaction in comparison to infiltration with F-box- $R z 2$ alone (data not shown). The F-box agroinfiltration experiment was repeated with leaves of resistant and susceptible sugar beet genotypes, but tissue necrosis was not observed (data not shown). Although agroinfiltration with pBin did not induce the tissue necrosis, the possibility remained that the agroinfection process might have interfered with it. Transient expression via particle bombardment with co-expression of a fluorescent marker was chosen to exclude the possible agrobacterium effect. $N$. benthamiana leaves were used for bombardment with $\mathrm{pBin}-\mathrm{F}-\mathrm{box}-\mathrm{Rz} 2$ plus the gene for DsRed (PCR-amplified from pDsRed-C1, Clontech) under control of CaMV $35 S$ and pA (pe35-DsRed) and pBin-F-box-Rz2 alone. pe35-DsRed plus pBin were co-bombarded as positive control. At 3 dpi five leaves of each treatment were analysed under epifluorescence microscopy (FM). Bombardment with F-box alone resulted in detection of 67 single epidermal cells showing autofluorescence induced by necrosis indicative for cell death, while no DsRed 
fluorescence was detected. Co-bombardment of F-box plus DsRed resulted in 87 green and 7 red fluorescing cells. In contrast bombardment with DsRed alone led to 131 cells showing red and only 5 cells displaying green fluorescence, demonstrating that i) a high percentage of cells was hit with both plasmids and ii) transient DsRed expression was suppressed when F-box protein was co-expressed. These observations suggested that with or without agrobacteria, the transient expression of sugar beet F-box protein induced cell death in N. benthamiana leaf cells.
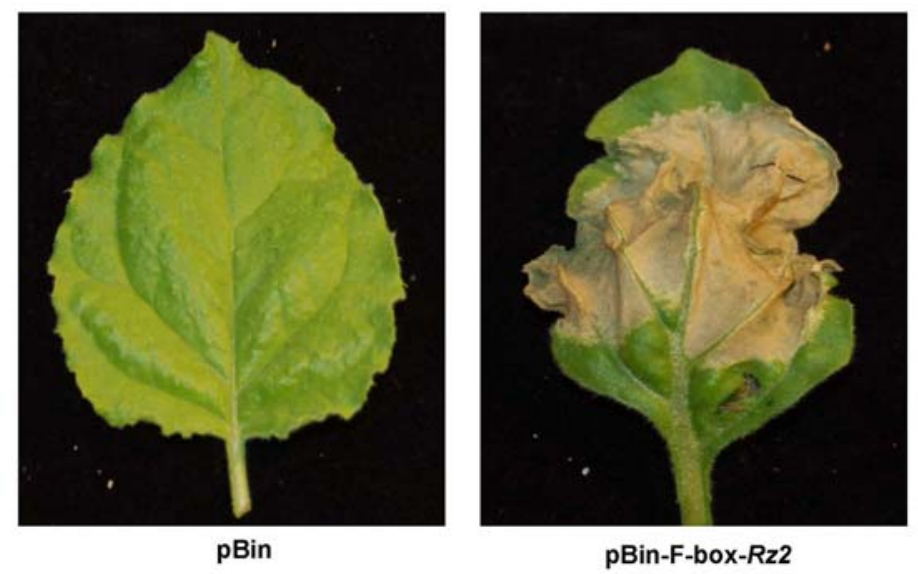

Figure 5. Host response of $N$. benthamiana leaf tissue following transient agrobacterium mediated expression of $R z 2$ sugar beet F-box protein (pBin-F-box$R z 2$ ) at 3 dpi. Agroinfiltration of an empty vector served as control (pBin-empty).

Transient F-box protein expression induces the accumulation of pathogenesis-related protein transcripts in $\mathbf{N}$. benthamiana leaf tissue

To evidence for a relation of the necrosis rapidly produced by transient F-box expression with cell death induced by a hypersensitive response, we attempted to show the accumulation of PR protein transcripts. To address this issue, $N$. benthamiana leaf tissue was agroinfiltrated with $\mathrm{pBin}-\mathrm{F}-\mathrm{box}-\mathrm{Rz} 2$ and $\mathrm{pBin}$. As no coding sequences from $N$. benthamiana related to PR-proteins are known, specific primers for $N$. tabacum PR-1a, $P R-1 b$ and $P R-1 c$ genes, known to be closely associated with the hypersensitive resistance response in tobacco, were applied.

At 24 and $36 \mathrm{hpi}$, total RNA was extracted and used for RT-PCR amplification of $P R-1 a, P R-1 b$ and $P R-1 c$ transcripts with specific primers. 
Amplification of constitutively expressed translation elongation factor gene transcripts (EF1 $\alpha)$ with specific primers served as internal control (Fig. 6). Strongly increased expression levels, relative to tissue infiltrated with $\mathrm{pBin}$, were observed for all three $P R-1 a, P R-1 b, P R-1 c$ transcripts at 24 as well as $36 \mathrm{hpi}$, suggesting a connection of sugar beet F-box protein with the induction of $H R$ in N. benthamiana.

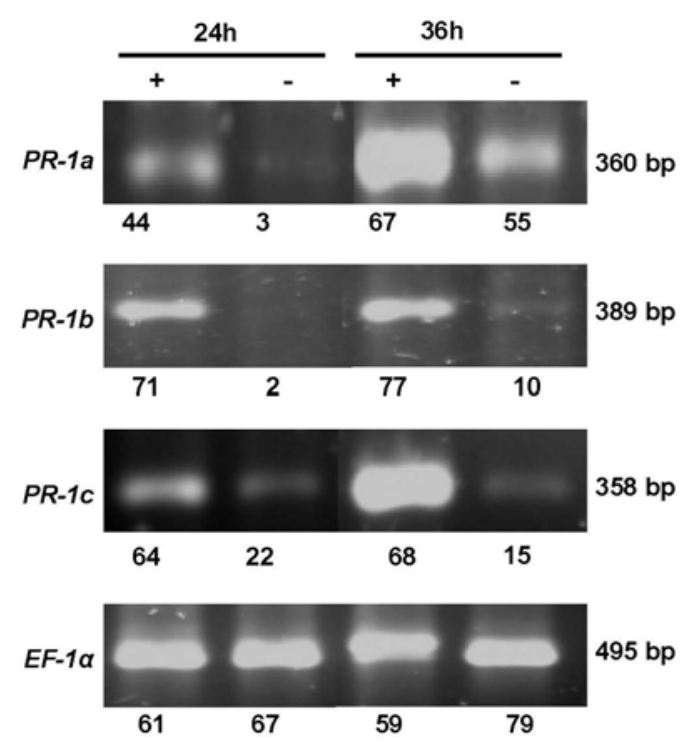

Figure 6. Induction of PR-protein gene ( $P R-1 a, P R-1 b, P R-1 c)$ expression in $N$. benthamiana leaf tissue agroinfiltrated $(+)$ with F-box-Rz2 (pBin-F-box-Rz2) and control infiltrated (-) with $p B i n$ vector was analysed by semi-quantitative RT-PCR after 24 and 36h. RT-PCR amplification of constitutively expressed EF1a transcripts was set as a quantitative standard. Results were reproduced for two times. Numbers below the gels display total area densities of the different RTPCR signals.

Full-length F-box protein is necessary for BNYVV P25 interaction as well as for cell-death induction in $\mathrm{N}$. benthamiana leaf tissue

To find a first indication if P25 interferes with F-box substrate recognition or F-box SCF complex interaction, LexA-YTH studies were performed with $\mathrm{N}$ - and $\mathrm{C}$ terminal parts of the $R z 2$ full-length F-box protein containing the conserved F-box motifs and kelch repeats, respectively. The coding sequence for the $\mathrm{N}$-terminal 187 and C-terminal 255 aa, respectively, were re-amplified with specific primers and cloned into LexA-BD vector (pJG4-5-F-box- $\Delta N$ and $-\Delta C$ ). However, in YTH 
analysis both deletion variants did not interact with P25 (Fig. 2a and b), despite detectable yeast expression was observed (Fig. 3).

Subsequently we wanted to figure out, if the cell-death induced by the full-length F-box protein can be ascribed to one of the two functional domains of the protein. Therefore, F-box-Rz2- $\Delta \mathrm{N}$ and $-\Delta \mathrm{C}$ were transiently expressed from $\mathrm{pBin}$ vectors in $N$. benthamiana leaf tissue, but no cell death was observed for both treatments.

\section{DISCUSSION}

Current knowledge of P25's role in virus pathogenicity and sugar beet antivirus resistance mechanism

Several lines of evidence established during the last two decades have connected BNYVV RNA3 encoded P25 protein and its aa67-70 tetrad composition to virus pathogenicity in $B$. vulgaris roots $(26,54)$ and necrosis induction in leaves of $B$. maritima as well as Tetragonia expansa $(6,25,52)$. In addition both transcriptomic (45) and proteomic (29) studies applying BNYVV infected susceptible sugar beet revealed induction of defense and oxidative stress related genes, fitting to the typically virus-induced root cell necrosis and phytohormone imbalance (40). Taken together the observations strongly suggest a hypersensitive resistance response against virus infection, unable to limit virus spread in susceptible genotypes. Even though, the underlying resistance mechanism mediated by $R z$ major genes has not been resolved yet and the identification of the Rz-gene product is currently missing.

\section{Significance of the P25 F-box interaction}

The results of this study show that out of three P25 interacting sugar beet proteins connected to the UPS (Thiel and Varrelmann, submitted for publication)), one F-box candidate indeed represents an F-box protein as proven here via Arabidopsis ASK1 and ASK2 interaction and displays predicted F-box and kelch domains. Identified in the Rz2 sugar beet LexA-YTH based cDNA screen, the P25 F-box interaction belonged to the strongest interactions among the 36 candidates analyzed (Thiel and Varrelmann, submitted for publication). This was supported by the finding that quantification of the interaction strength in the YTH- 
Gal4 confirmation test via measurement of yeast $\beta$-gal activity resulted in a twofold higher value than the P53-LTA control, which is known to represent already a strong interaction (58). Moreover, the GST pull-down assay precluded the interference of yeast proteins with the interaction.

\section{The putative cellular function of the sugar beet F-box protein}

The fortuitous finding of necrosis induction in $N$. benthamiana leaf tissue following transient agrobacterium-mediated F-box expression in BiFC assay suggested an involvement of the protein in the induction of a hypersensitive response. This was supported by the induced expression of PR-protein transcripts (PR-1a, PR-1b and $P R-1 c$ ). As Tamada (52) and Chiba et al. (6) had observed necrotic lesions in leaves of BNYVV resistant $B$. maritima plants following rub-inoculation thus limiting BNYVV replication and spread, we expected to reproduce the necrosis via agrobacterium mediated overexpression in sugar beet leaf tissue in unnatural high concentrations but failed to do so. A possible explanation is the extraordinary high agrobacterium-mediated expression level in $N$. benthamiana leaf tissue compared to sugar beet, where A. tumefaciens transient expression of reporter genes like green fluorescent protein result only in very poor fluorescence (data not shown). The observation, that the separated domains of the F-box (N-terminal F-box and C-terminal kelch repeats) did not induce necrosis are indicative for the targeting of a plant protein (e.g. a transcriptional factor) to the UPS, whose absence allows HR related genes to be expressed only when both domains are available in one protein. Co-expression of both F-box domain and the kelch repeats via transient agroinfection in two separate molecules as well did not lead to induction of necrosis supporting the idea that an unknown F-box target needs to be directed to the UPS to induce HR. Several studies have demonstrated that targets of F-box proteins can represent transcription regulators and their UPS mediated degradation induced gene expression (56). Future studies should apply stable overexpression or RNAi-based knock-out in transgenic sugar beets using full-length and deletion constructs to determine if interference with resistance against BNYVV or the response to infection with other pathogens can be generated. 
As the C-terminal kelch-repeat target interaction domain structure is different from those F-box proteins with a known role in HR or SAR (SON1 and ACRE189) and no significant sequence homology was observed, functional homology cannot be deduced. In contrast to kelch repeats, tobacco ACRE189 displays a Leu-rich repeat (56) whereas no distinct interaction domain was predictable at the $A$. thaliana. SON1 C-terminus (23). Secondary YTH sugar beet cDNA library screens might be useful to identify cellular ubiquitylation targets of the F-box identified in this study to unravel the F-box function and prove its possible role as a central component of the HR response in sugar beet.

\section{Does the observed interaction lead to plant resistance or enables} virus pathogenicity?

With the isolation of F-box full-length alleles, we intended to uncover an $R z 2$ resistance specific P25 interaction, pinpointing to a P25 recognition and subsequent resistance reaction induction. Unexpectedly this was not the case. The $34 \mathrm{~N}$-terminal aa extension of the full-length Rz2 F-box did not significantly interfere with the interaction, although the yeast expression level to unknown reasons was obviously reduced. However, the confirmation of the P25 interaction with independently isolated $R z 1$ and susceptible full-length alleles supported the relevance of the interaction detected, rather indicating the F-box protein to represent a target for P25 what might enable the virus to exert a pathogenic influence on the host. Remarkably, cDNA RT-PCR based isolation of full-length sequences from total RNA was performed from healthy non-infected sugar beet seedlings, suggesting a constitutive instead of pathogen inducible expression of this F-box protein. Moreover, the P25 variant from a BNYVV isolate with the ability to generate elevated virus concentration in both $R z 1$ and $R z 2$ genotypes (35), did not display reduced or missing interaction with the F-box protein. It is widely accepted that the F-box C-terminal kelch-repeat domain is usually responsible for the target binding (5), but a P25 interaction with this domain was not identified, suggesting that P25 targeting for UPS degradation cannot be expected although final evidence was not supplied. All these findings account for a resistance independent interaction and in addition a relation to resistance breaking could be ruled out. On the contrary, the findings support the F-box target 
hypothesis and suggest that P25 might interact with F-box to suppress a resistance reaction, which is $R z$-independent. The finding, however, that P25 Fbox transient overexpression in N. benthamiana leaves was not reducing or delaying the necrotic reaction is an argument against this, although conclusions are difficult to draw as $N$. benthamiana is a BNYVV host which displays only very mild symptoms and no necrosis or comparable resistance reaction. Sugar beet Fbox sequences were passed to all three major sugar beet breeding companies (KWS SAAT AG, Einbeck, Germany; STRUBE-DIECKMANN GmbH \& Co. KG, Söllingen, Germany and Syngenta Seeds AB, Landskrona, Sweden) and used for genomic mapping. The F-box gene was mapped to chromosome 5 (data not shown) and therefore can be excluded to represent an $R z$ major gene which has been mapped to chromosome 3 (47).

\section{The possible role of $\mathrm{P} 25$}

The findings of this study and our previous observations (Thiel and Varrelmann, submitted for publication) suggest that P25 interferes with the plants UPS at independent positions (two non-related F-box and one U-box protein). Previous work on P25 functional characterisation determined nuclear shuttling abilities (57) and the tendency to form oligomers as well as slight transcriptional activation. In addition the protein contains a Zinc-finger and acidic domain (25). However SMART analysis of the P25 aa sequence did not result in prediction of domains which indicate a relation to the UPS and Gal4-YTH did not identify an interaction with SKP1. To hypothesize a possible P25 function or functional role of the interaction detected, a side glance on other viral proteins which could interfere with the host UPS might be helpful. In general it can be assumed that viruses try to eliminate the stoichiometric imbalance of host target proteins over viral proteins to favour their own multiplication (2). Several viruses developed mechanisms to send the recruited host target proteins for degradation to the $26 \mathrm{~S}$ proteasome. The silencing suppressor protein P0 of the Poleroviruses contains an F-box motif at the $\mathrm{N}$-terminus (37) and the authors demonstrated that $\mathrm{P} 0$ targets a component of the RNA silencing to the SCF-complex. In contrast, the movement protein (MP) of tobacco mosaic virus is degraded following ubiquitylation and Reichel and Beachy (42) suggested that the virus uses the process to control virus movement 
via limiting the damaging influence of the MP on the structure of the cortical endoplasmatic reticulum. Remarkably, another potyviral silencing suppressor (HC-Pro) has revealed interactions with plant proteins similar to the P25 partners. Jin et al. (21) detected potato virus Y (PVY) HC-Pro interactions with subunits of the Arabidopsis $20 \mathrm{~S}$ proteasome. Accordingly the P25 YTH cDNA library screen identified another candidate with significant homology to a protein from potato which previously was identified to interact with potato virus A (PVA) HC-Pro, named HC-Pro interacting protein 2 (HIP2) (14). To verify that P25 [in addition to RNA2 encoded P14 (8) and P31 expressed from RNA4 (41)] might possess as well silencing suppressor functions, we performed an agrobacterium mediated transient silencing suppression assay according to Voinnet et al. (60) but did not observe any silencing suppression effect (data not shown).

The ways by which plant virus proteins interfere with the UPS are quite diverse and although few studies exist which show at least some similarities, the final understanding how P25 exerts its function as pathogenicity factor is still missing. Future studies performing functional characterisation of other candidates identified previously (Thiel and Varrelmann, submitted for publication)) will help to finally resolve the sugar beet antivirus resistance mechanism and understand the virus life cycle to develop sustainable control strategies against rhizomania.

\section{ACKNOWLEDGEMENTS}

This research project has been carried out with the financial support of the Federal Ministry of Economics and Technology (BMWi), administered via the Arbeitsgemeinschaft industrieller Forschungsvereinigungen e.V. (AiF) and the Gemeinschaft zur Förderung der privaten deutschen Pflanzenzüchtung e.V. (GFP). K.H. was supported by a Franco-Syrian grant. The authors are grateful to Danielle Scheidecker for technical assistance. 


\section{REFERENCES}

1. Bai, C., P. Sen, K. Hofmann, L. Ma, M. Goebl, J. W. Harper, and S. J. Elledge. 1996. SKP1 connects cell cycle regulators to the ubiquitin proteolysis machinery through a novel motif, the F-box. Cell. 86: 263-274.

2. Banks, L., P. Pim, and M. Thomas. 2003. Viruses and the $26 \mathrm{~S}$ proteasome: hacking into destruction. Trends Biochem. Sci. 28: 452-459.

3. Biancardi, E., R. T. Lewellen, M. De Biaggi, A. W. Erichsen, and P. Stevanato. 2002. The origin of rhizomania resistance in sugar beet. Euphytica. 127: 383-397.

4. Bork, P., and R. F. Doolittle. 1994. Drosophila Kelch Motif Is Derived from a Common Enzyme Fold. J. Mol. Biol. 236: 1277-1282.

5. Cardozo, T., and M. Pagano. 2004. The SCF ubiquitin ligase: Insights into a molecular machine. Nat. Rev. Mol. Cell Biol. 5: 739-751.

6. Chiba, S., M. Miyanishi, I. B. Andika, H. Kondo, and T. Tamada. 2008. Identification of amino acids of the beet necrotic yellow vein virus p25 protein required for induction of the resistance response in leaves of Beta vulgaris plants. J. Gen. Virol. 89: 1314-1323.

7. Cormack, R. S., K. Hahlbrock, and I. E. Somssich. 1998. Isolation of putative plant transcriptional coactivators using a modified two-hybrid system incorporating a GFP reporter gene. Plant J. 14: 685-692.

8. Dunoyer, P., S. Pfeffer, C. Fritsch, O. Hemmer, O. Voinnet, and K. E. Richards. 2002. Identification, subcellular localization and some properties of a cysteine-rich suppressor of gene silencing encoded by peanut clump virus. Plant J. 29: 555-567. 
9. Fields, S., and O. K. Song. 1989. A Novel Genetic System to Detect Protein Protein Interactions. Nature. 340: 245-246.

10. Gagne, J. M., B. P. Downes, S. H. Shiu, A. M. Durski, and R. D. Vierstra. 2002. The F-box subunit of the SCF E3 complex is encoded by a diverse superfamily of genes in Arabidopsis. Proc. Natl. Acad. Sci. U S A. 99: 1151911524.

11. Gray, D. J., E. Hiebert, C. M. Lin, M. E. Compton, D. W. Mccolley, R. J. Harrison, and V. P. Gaba. 1994. Simplified Construction and Performance of a Device for Particle Bombardment. Plant Cell. Tiss. Org. 37: 179-184.

12. Grimmer, M., S. Trybush, S. Hanley, S. Francis, A. Karp, and M. Asher. 2007. An anchored linkage map for sugar beet based on AFLP, SNP and RAPD markers and QTL mapping of a new source of resistance to Beet necrotic yellow vein virus. Theor. Appl. Genet. 114: 1151-1160.

13. Guo, H. W., and J. R. Ecker. 2003. Plant responses to ethylene gas are mediated by SCF (EBF1/EBF2)-dependent proteolysis of EIN3 transcription factor. Cell. 115: 667-677.

14. Guo, D., C. Spetz, M. Saarma, and J. P. T. Valkonen. 2003. Two Potato Proteins, Including a Novel RING Finger Protein (HIP1), Interact with the Potyviral Multifunctional Protein HCpro. Mol. Plant Microbe Interact. 16: 405410.

15. Gyuris, J., E. Golemis, H. Chertkov, and R. Brent. 1993. Cdi1, a human G1 and S phase protein phosphatase that associates with Cdk2. Cell. 75: 791-803.

16. Haasen, D., C. Kohler, G. Neuhaus, and T. Merkle. 1999. Nuclear export of proteins in plants: AtXPO1 is the export receptor for leucine-rich nuclear export signals in Arabidopsis thaliana. Plant J. 20: 695-705. 
17. Heijbroek, W., P. M. S. Musters, and A. H. L. Schoone. 1999. Variation in pathogenicity and multiplication of beet necrotic yellow vein virus (BNYVV) in relation to the resistance of sugar-beet cultivars. Eur. J. Plant Pathol. 105: 397-405.

18. Hershko, A., and A. Ciechanover 1998. The ubiquitin system. Annu. Rev. Biochem. 67: 425-479.

19. Ho, M. S., P. I. Tsai, and C. T. Chien. 2006. F-box proteins: the key to protein degradation. J. Biomed. Sci. 13: 181-191.

20. Iwabuchi, K., B. Li, P. Bartel, and S. Fields. 1993. Use of the 2-Hybrid System to Identify the Domain of P53 Involved in Oligomerization. Oncogene. 8: 1693-1696.

21. Jin, Y., D. Ma, J. Dong, J. Jin, D. Li, C. Deng, and T. Wang. 2007. HC-Pro protein of Potato virus $\mathrm{Y}$ can interact with three Arabidopsis $20 \mathrm{~S}$ proteasome subunits in planta. J. Virol. 81: 12881-12888.

22. Keskin, B. 1964. Polymyxa Betae Nsp Ein Parasit in Den Wurzeln Von Beta Vulgaris Tournefort Besonders Wahrend Der Jugendentwicklung Der Zuckerrube. Archiv Für Mikrobiologie. 49: 348-374.

23. Kim, H. S., and T. P. Delaney. 2002. Arabidopsis SON1 is an F-box protein that regulates a novel induced defense response independent of both salicylic acid and systemic acquired resistance. Plant Cell. 14: 1469-1482.

24. Kipreos, E. T., and M. Pagano. 2000. The F-box protein family. Genome Biol. 1: 3002.1-3002.7. 
25. Klein, E., D. Link, A. Schirmer, M. Erhardt, and D. Gilmer. 2007. Sequence Variation within Beet necrotic yellow vein virus p25 protein influences its oligomerization and isolate pathogenicity on Tetragonia expansa. Virus Res. 126: 53-61.

26. Koenig, R., W. Jarausch, Y. Li, U. Commandeur, W. Burgermeister, M. Gehrke, and P. Luddecke. 1991. Effect of Recombinant Beet Necrotic Yellow Vein Virus with Different RNA Compositions on Mechanically Inoculated Sugar-Beets. J. Gen. Virol. 72: 2243-2246.

27. Kuroda, H., N. Takahashi, H. Shimada, M. Seki, K. Shinozaki, and M. Matsui. 2002. Classification and expression analysis of Arabidopsis F-boxcontaining protein genes. Plant Cell Physiol. 43: 1073-1085.

28. Laemmli, U. K. 1970. Cleavage of structural proteins during the assembly of the head of bacteriophage T4. Nature. 227: 680-685.

29. Larson, R. L., W. M. Wintermantel, A. Hill, L. Fortis, and A. Nunez. 2008. Proteome changes in sugar beet in response to Beet necrotic yellow vein virus. Physiol. Mol. Plant P. 72: 62-72.

30. Lechner, E., P. Achard, A. Vansiri, T. Potuschak, and P. Genschik. 2006. F-box proteins everywhere. Curr. Opin. Plant Biol. 9: 631-638.

31. Letunic, I., R. R. Copley, S. Schmidt, F. D. Ciccarelli, T. Doerks, J. Schultz, C. P. Ponting, and P. Bork. 2004. SMART 4.0: towards genomic data integration. Nucleic Acids Res. 32: 142-144.

32. Li, B., and S. Fields. 1993. Identification of Mutations in P53 That Affect Its Binding to SV40 Large T-Antigen by Using the Yeast 2-Hybrid System. FASEB Journal. 7: 957-963. 
33. Link, D., L. Schmidlin, A. Schirmer, E. Klein, M. Erhardt, A. Geldreich, O. Lemaire, and D. Gilmer. 2005. Functional characterization of the Beet necrotic yellow vein virus RNA-5-encoded p26 protein: evidence for structural pathogenicity determinants. J. Gen. Virol. 86: 2115-2125.

34. Liu, H. Y., and R. T. Lewellen. 2007. Distribution and molecular characterization of resistance-breaking isolates of Beet necrotic yellow vein virus in the United States. Plant Disease. 91: 847-851.

35. Liu, H. Y., J. L. Sears, and R. T. Lewellen. 2005. Occurrence of resistancebreaking Beet necrotic yellow vein virus of sugar beet. Plant Disease. 89: 464-468.

36. Luterbacher, M. C., M. J. C. Asher, W. Beyer, G. Mandolino, O. E. Scholten, L. Frese, E. Biancardi, P. Stevanato, W. Mechelke, and O. Slyvchenko. 2005. Sources of resistance to diseases of sugar beet in related Beta germplasm: II. Soil-borne diseases. Euphytica. 141: 49-63.

37. Pazhouhandeh, M., M. Dieterle, K. Marrocco, E. Lechner, B. Berry, V. Brault, O. Hemmer, T. Kretsch, K. E. Richards, P. Genschik, and V. Ziegler-Graff. 2006. F-box-like domain in the polerovirus protein PO is required for silencing suppressor function. Proc. Natl. Acad. Sci. 103: 19941999.

38. Pferdmenges, F., H. Korf, and M. Varrelmann. 2008. Identification of rhizomania-infected soil in Europe able to overcome Rz1 resistance in sugar beet and comparison with other resistance-breaking soils from different geographic origins. Eur. J. Plant Pathol, doi: 10.1007/s10658-008-9388-9.

39. Pfitzner, U. M., and H. M. Goodman. 1987. Isolation and characterization of cDNA clones encoding pathogenesis-related proteins from tobacco mosaic virus infected tobacco plants. Nucleic Acids Res. 15: 4449-4465. 
40. Pollini, C. P., and L. Giunchedi. 1989. Comparative histopathology of sugar beets that are susceptible and partially resistant to rhizomania. Phytopathol. Mediteran. 28:16-21.

41. Rahim M. D., I. B. Andika, C. Han, H. Kondo, and T. Tamada. 2007. RNA4encoded p31 of beet necrotic yellow vein virus is involved in efficient vector transmission, symptom severity and silencing suppression in roots. J. Gen. Virol. 88: 1611-1619.

42. Reichel, C., and R. N. Beachy. 2000. Degradation of tobacco mosaic virus movement protein by the $26 \mathrm{~S}$ proteasome. J. Virol. 74: 3330-3337.

43. Risseeuw, E. P., T. E. Daskalchuk, T. W. Banks, E. Liu, J. Cotelesage, H. Hellmann, M. Estelle, D. E. Somers, D. E., and W. L. Crosby. 2003. Protein interaction analysis of SCF ubiquitin E3 ligase subunits from Arabidopsis. Plant J. 34: 753-767.

44. Sambrook, J., E. F. Fritsch, and T. Maniatis. 1989. Molecular cloning: A Laboratory Manual: Cold Spring Harbor Laboratory, Cold Spring Harbor, NY, U.S.A.

45. Schmidlin, L., E. de Bruyne, G. Weyens, M. Lefebvre, and D. Gilmer. 2008. Identification of differentially expressed root genes upon rhizomania disease. Mol. Plant Pathol. 9: 741-51.

46. Schirmer, A., D. Link, V. Cognat, B. Moury, M. Beuve, A. Meunier, C. Bragard, D. Gilmer, and O. Lemaire. 2005. Phylogenetic analysis of isolates of Beet necrotic yellow vein virus collected worldwide. J. Gen. Virol. 86: 28972911.

47. Scholten, O. E., T. S. M. De Bock, R. M. Klein-Lankhorst, and W. Lange. 1999. Inheritance of resistance to beet necrotic yellow vein virus in Beta vulgaris conferred by a second gene for resistance. Theor. Appl. Genet. 99: 740-746. 
48. Scholten, O. E., and W. Lange, W. 2000. Breeding for resistance to rhizomania in sugar beet: A review. Euphytica. 112: 219-231.

49. Scholten, O. E., H. Paul, D. Peters, J. W .M. Vanlent, and R. W. Goldbach. 1994. In-Situ Localization of Beet Necrotic Yellow Vein Virus (BNYVV) in Rootlets of Susceptible and Resistant Beet Plants. Arch. Virol. 136: 349-361.

50. Schultz, J., F. Milpetz, P. Bork, and C. P. Ponting. 1998. SMART, a simple modular architecture research tool: Identification of signaling domains. Proc. Natl. Acad. Sci. U S A. 95: 5857-5864.

51. Szurek, B., E. Marois, U. Bonas, and G. Van den Ackerveken. 2001. Eukaryotic features of the Xanthomonas type III effector AvrBs3: protein domains involved in transcriptional activation and the interaction with nuclear import receptors from pepper. Plant J. 26: 523-534.

52. Tamada, T. 2007. Susceptibility and resistance of Beta vulgaris subsp. maritima to foliar rub-inoculation with Beet necrotic yellow vein virus. J. Gen. Plant Pathol. 73: 76-80.

53. Tamada, T., T. Kusume, H. Uchino, T. Kiguchi, and M. Saito. 1996. Evidence that beet necrotic yellow vein virus RNA-5 is involved in symptom development of sugar-beet roots. In: Sherwood, J.L.; Rush, C.M. (Hrsg.). Proc. 3rd Symp. of the Int. Working Group on Plant Viruses with Fungal Vectors, Dundee (UK). 49-52.

54. Tamada, T., H. Uchino, T. Kusume, and M. Saito. 1999. RNA 3 deletion mutants of beet necrotic yellow vein virus do not cause rhizomania disease in sugar beets. Phytopathology. 89: 1000-1006. 
55. Thompson, J. D., D. G. Higgins, and T. J. Gibson. 1994. CLUSTAL W: improving the sensitivity of progressive multiple sequence alignment through sequence weighting, position-specific gap penalties and weight matrix choice. Nucleic Acids Res. 22: 4673-4680.

56. van den Burg, H. A., D. I. Tsitsigiannis, O. Rowland, J. Lo, G. Rallapalli, D. Maclean, F. L. Takken, and J. D. Jones. 2008. The F-box protein ACRE189/ACIF1 regulates cell death and defense responses activated during pathogen recognition in tobacco and tomato. Plant Cell. 20: 697-719.

57. Vetter, G., J. M. Hily, E. Klein, L. Schmidlin, M. Haas, T. Merkle, and D. Gilmer. 2004. Nucleo-cytoplasmic shuttling of the beet necrotic yellow vein virus RNA-3-encoded p25 protein. J. Gen. Virol. 85: 2459-2469.

58. Veyron-Churlet, R., S. Bigot, O. Guerrini, S. Verdoux, W. Malaga, M. Daffé, and D. Zerbib. 2005. The Biosynthesis of Mycolic Acids in Mycobacterium tuberculosis Relies on Multiple Specialized Elongation Complexes Interconnected by Specific Protein-Protein Interactions J. Mol. Biol. 353: 847-858.

59. Vierstra, R. D. 2003. The ubiquitin/26S proteasome pathway, the complex last chapter in the life of many plant proteins. Trends Plant Sci. 8: 135-142.

60. Voinnet, O., Y. M. Pinto, and D. Baulcombe. 1999. Suppression of gene silencing: a general strategy used by diverse DNA and RNA viruses of plants. Proc. Natl. Acad. Sci. U S A. 96: 14147-14152.

61. Voinnet, O., S. Rivas, P. Mestre, and D. Baulcombe. 2003. An enhanced transient expression system in plants based on suppression of gene silencing by the 19 protein of tomato bushy stunt virus. Plant J. 33: 949-956.

62. Whitney, E. D. 1989. Identification, Distribution, and Testing for Resistance to Rhizomania in Beta-Maritima. Plant Disease. 73: 287-290. 
63. Xue, F. Y., and L. Cooley. 1993. Kelch Encodes a Component of Intercellular Bridges in Drosophila Egg Chambers. Cell. 72: 681-693.

64. Zhang, Z.-G., Y.-C. Wang, J. Li, R. Ji, G. Shen, S.-C. Wang, X. Zhou, and X.-B. Zheng. 2004. The role of SA in the hypersensitive response and systemic acquired resistance induced by elicitor PB90 from Phytophthora boehmeriae. Physiol Mol. Plant P. 65: 31-38 


\section{Kapitel 5: Diskussion}

\subsection{Beurteilung des Yeast two-hybrid Systems als Screening-Methode zur Identifizierung von Proteininteraktionen}

Zur Charakterisierung des Resistenz-/Pathogenitätsmechanismus des Pathosystems Zuckerrübe-BNYVV konnten, in einem LexA basierenden YTH System, Wirtsproteine identifiziert werden, die mit dem Pathogenitätsfaktor P25 des BNYVV interagieren. Für die Durchführung dieses Protein-ProteinInteraktionsassays wurde aus Gesamt-RNA-Präparationen von Blatt- und Wurzelmaterial einer $R z 2$-resistenten, homozygoten Zuckerrübenlinie eine cDNA Bibliothek erstellt (Vertis Biotechnologie AG, Freising, Anhang). Diese

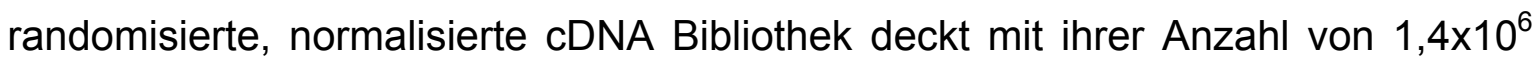
unabhängigen Klonen einer durchschnittlichen cDNA-Klonlänge von $>0,4 \mathrm{~kb}$ unter der Annahme von mindestens 25.000 Genen (Koch, 2006) das Transkriptom der Zuckerrübe ca. 56-fach ab. Ein Vergleich der Parameter „Anzahl von cDNA Klonen" und "Genomredundanz" mit anderen pflanzlichen cDNA Bibliotheken (Tabelle 1) bestätigt, dass die in dieser Arbeit aus Zuckerrübe erstellte cDNA Bibliothek eine repräsentative Ressource für die Anwendung im YTH darstellte.

Tabelle 1: Vergleich von cDNA Bibliotheken verschiedener Pflanzen

\begin{tabular}{|c|c|c|c|}
\hline Pflanze & $\begin{array}{l}\text { Anzahl der } \\
\text { cDNA Klone }\end{array}$ & $\begin{array}{l}\text { Genom- } \\
\text { abdeckung }\end{array}$ & Referenzen und Studien \\
\hline \multirow[t]{3}{*}{ A. thaliana } & $3 \times 10^{6}$ & 113-fach & Piroux et.al, 2007 \\
\hline & & & van der Biezen und Jones., 1998 \\
\hline & & & Goodin et al., 2008 \\
\hline \multirow[t]{2}{*}{ N. tabacum } & $1,55 \times 10^{6}$ & 47-fach & Soellick et al., 2000 \\
\hline & & & Goodin et al., 2008 \\
\hline N. benthamiana & $1,2 \times 10^{6}$ & unbekannt & Jiminez et al., 2006 \\
\hline Oryza sativa & $2 \times 10^{6}$ & 53-fach & Zhou et al., 2007 \\
\hline Solanum tuberosum & $2 \times 10^{6}$ & unbekannt & Guo et al., 2003 \\
\hline
\end{tabular}

Eine hohe Transkriptomabdeckung in der erstellten Zuckerrüben cDNA Bibliothek ist für erfolgreiche Arbeiten im YTH von großer Bedeutung. Wegen der Expression des cDNA-Klons als Fusionsprotein mit der Aktivierungsdomäne B42 im Hefevektor muss eine zusätzliche Reduktion der angegebenen 
Transkriptomabdeckung berücksichtigt werden. Denn aufgrund der Ligation jeder cDNA in allen drei möglichen Leserastern mit dem Plasmid befindet sich theoretisch nur jeder dritte Klon im korrekten Leserahmen bei der Translatierung von Nukleotidtripletts in Aminosäuren.

Die Durchmusterung der Zuckerrüben cDNA Bank resultierte in ca. $1 \times 10^{6}$ Hefekolonien, aus denen 450 potentielle Kandidaten für die weitere Überprüfung selektiert wurden. Um starkes Hintergrundwachstum durch sogenannte Autoaktivierungskandidaten, die die Fähigkeit besitzen, die Transkription der Reportergene selbständig zu aktivieren, zu verringern, wurde eine Selektionskontrolle auf Festmedium für alle 450 Kandidaten durchgeführt, wie sie auch in anderen Hefesystemen z.B. DupLEX-A (Origene, Rockville) oder MATCHMAKER (Clontech, Terra Bella) angewendet wird. Um die Effizienz für die Ausmusterung der falsch-positiven Interaktionen zu erhöhen, wurde in dieser Arbeit ein zusätzlicher, auf Flüssigmedium basierender Selektionsschritt durchgeführt. Viele potentiell interagierende Kandidaten konnten durch diese weitere Überprüfung kosten- und zeitsparend als falsch-positive Interaktionen selektiert und ausgemustert werden. Dies begründet sich in unterschiedlichen Wachstumsbedingungen von Hefezellen im Fest- bzw. Flüssigmedium. Auf Festmedium kann das Wachstum von Hefezellen in bestimmten Konzentrationen auf bereits absterbenden und toten Hefezellen weiterhin stattfinden. Ein solches Wachstum ist in Flüssigkulturen ausgeschlossen und ermöglicht so einen zuverlässigeren Ausschluss von falsch-positiven Interaktionen. Eine zusätzliche Selektion falsch-positiver Interaktionen besteht in dem Austausch der zu testenden Proteine innerhalb der Hefevektoren, nach der die Interaktion weiterhin detektierbar bleiben sollte (Chien et al., 1991). Eine im „prey“ Plasmid vorliegende, einzelne Restriktionsschnittstelle wird verwendet, um nach einem Restriktionsverdau des Plasmides, die überhängenden Enden aufzufüllen und durch Ligation dieses wieder zusammenzufügen. Damit kommt es zur Verschiebung des offenen Leserahmens. Anschließend sollte als Kontrolle eine Protein-Protein Interaktion nicht mehr möglich sein. Wird doch Wachstum von Hefezellen angeregt, so kann diese nicht durch die Proteinexpression, sondern nur von der in Hefe transkribierten RNA hervorgerufen werden (Bendixen et al., 1994). 
Die Durchführung weiterer Kontrollen war im zeitlichen Rahmen der Arbeit nicht realisierbar und aufgrund der hohen Selektionsrate der durchgeführten Ausschlussverfahren nicht erforderlich.

Letztlich wurde bei der in dieser Arbeit durchgeführten Fest- und Flüssigmedien basierten Selektion die Zahl der ursprünglich ausgewählten 450 Kandidaten um $88 \%$ auf verbliebene 55 Kandidaten reduziert. In nachfolgenden Einzelinteraktionsprüfungen mit P25 wurden weitere 19 Kandidaten als wahre Interaktionskandidaten des P25 ausgeschlossen. Damit verblieben schlussendlich 36 Kandidaten (Kapitel 3). Die erfolgreiche Identifizierung von Kandidaten bei der Durchmusterung der Zuckerrüben cDNA Bibliothek liegt begründet in der hohen Selektionsrate von falsch-positiven Interaktionen.

In weiterführenden Arbeiten muss geklärt werden, ob die aufgedeckten P25 interagierenden cDNA Kandidaten tatsächlich an der Wirt-Virus Interaktion in der Zuckerrübe beteiligt sind. Bei der Nutzung der aus infizierten Wurzel- und Blattgeweben erstellten cDNA-Bank kann der Fall eintreten, dass Proteine räumlich zusammengebracht werden und miteinander interagieren, deren Interaktion im natürlichen Virus-Wirt Pathosystem aufgrund von Zellkompartimentierung, sowie temporär und räumlich differentieller Expression nicht möglich ist. Des Weiteren sollte eine Überprüfung in einem Hefezellen unabhängigen Protein-Protein Nachweis durchgeführt werden, um die im YTH Screen verwendeten S. cerevisae Wirtszellen als Ko-Faktoren der Interaktion auszuschließen (Causier und Davies, 2002). Dies begründet die Notwendigkeit, die funktionelle Bedeutung von identifizierten Protein-Protein-Interaktionen weiterführend zu charakterisieren.

Auffällig ist, dass kein Kandidat bei der Durchmusterung der cDNA Bibliothek doppelt identifiziert wurde. Eine mögliche Interpretation dessen kann die geringe Anzahl von 450 selektierten Kolonien aus geschätzten $1 \times 10^{6}$ Hefetransformanden im YTH Screen sein. Die Überprüfung einer Vielzahl von weiteren cDNA Kandidaten wäre zur Identifikation doppelter bzw. weiterer P25 interagierender Klone eine Möglichkeit gewesen. Dies war aufgrund der zeitaufwendigen Ausschlussarbeiten von falsch-positiven Kandidaten und der erforderlichen Bestätigung von Interaktionen im direkten YTH-Interaktionstest zwischen selektiertem „prey“ und eingesetzten „bait“ P25 nicht realisierbar. 


\subsection{Eignung des "Bimolecular fluorescence complementation assay" zur Interaktionsüberprüfung}

Als Ergebnis aus den YTH Untersuchungen konnten 36 positive, mit P25 interagierende Kandidatenproteine selektiert werden. Eine zweite Überprüfung und somit eine Bestätigung der YTH Ergebnisse ist generell unabdingbar. Dazu wurde das BiFC ausgewählt. Dieses in planta Protein-Protein-Interaktionssystem kann schnell und einfach durch Nutzung transienter Agroexpression im Blattparenchym von Tabakblättern durchführt werden (Walter et al., 2004). Von 36 cDNA Klonen, die als Interaktionspartner des Pathogenitätsfaktors P25 identifiziert wurden, konnten 10 Klone erneut durch rekonstituierte mRFP-Expression im Epifluoreszenz-Mikroskop auf P25 Interaktion bestätigt werden (Kapitel 3, Abb.2). Um die Qualität und Effizienz des BiFC Systems und die damit verbundenen Interaktions- und Proteinexpressionsergebnisse zu bewerten, müssen die Vorund Nachteile des Systems berücksichtigt werden.

Vergleiche mit den, in der Literatur beschriebenen BiFC Systemen zeigen, dass Unterschiede zwischen diesen und dem in dieser Arbeit neu konstruierten System vorliegen. In dem YFP System von Walter et al. (2004) und dem mRFP System von Jach et al. (2006) wurden die Kandidaten durch C-terminale Fusionen mit den verwendeten Fluoreszenzmarkerfragmenten verbunden. Dem gegenüber steht das für diese Arbeit neu erstellte System mit $\mathrm{N}$-terminalen Fusionen der Kandidaten an die in Anlehnung an Jach et al. (2006) gewählten mRFP Fragmente. Somit kommt es zur Veränderung der Positionierung der in allen drei Systemen gleich verwendeten "tags“ (Haemagglutinin bzw. c-myc), da diese zwischen Kandidatengen und Fluoreszenzmarker positioniert sind. Übereinstimmend standen die Expressionskonstrukte in binären Plasmiden unter CaMV-35S Promotorkontrolle. Ein Grund der im immunologischen Nachweis ausgebliebenen Proteinexpression kann ggf. durch die N-terminalen Fusionen der zu exprimierenden Proteine mit dem notwendigen „tag“ liegen. Eine Kontrolle, um einen Einfluss der Fluoreszenzmarker bzw. der "tag“-Position auszuschließen würde eine Neukonstruktion des Systems bedeuten.

Um jedoch eine komplette, positive Proteininteraktion anhand des Fluorophorsignals beurteilen zu können, sind sowohl Positiv- als auch 
Negativkontrollen für Interaktionen Bestandteile des Assays und Vorraussetzung für eine korrekte Beurteilung der untersuchten Proteininteraktion (Kerppola, 2006). Bei der in dieser Arbeit verwendeten BiFC-Variante kam es in den Untersuchungen auch in der Negativkontrolle nach fünf bis sechs Tagen zu einer geringen, aber detektierbaren Fluoreszenz. Dieses Zeitfenster zum Nachweis von physikalischen Interaktionen von 2-5 Tagen wurde auch in Arbeiten von Kerppola (2006), Kim et al. (2007) und Ohad et al. (2007) beobachtet. Deshalb ist der Proteininteraktionsnachweis zeitlich nach einer auftretenden Fluoreszenz der Negativkontrolle für alle durchgeführten Versuchsvarianten ab diesem Zeitpunkt zu vernachlässigen.

Ein weiterer Punkt ist die Intensität der Proteininteraktion. Sowohl an den detektierten Signalen im immunologischen Nachweis, als auch an der Fluoreszenzstärke im Mikroskop zeigten sich deutliche Unterschiede zwischen den mit P25 interagierenden cDNA Kandidaten (Kapitel 3, Abb. 2). Dabei sollten die Expressionsstärken von den zu testenden Interaktionen im BiFC System beobachtet werden, um mögliche falsch-positive Interaktionen ausschließen zu können (Bhat et al., 2006; Kerppola, 2008). Zur Überprüfung dieser sollte eine Kontrolle bei jeder Protein-Protein Interaktion mitgeführt werden, die eine solche Autoaktivierung des Systems sicher erkennen lässt. Der auf Interaktion zu testende Kandidat wird mit einem Protein, mit dem eine Interaktion nicht möglich ist, im BiFC System überprüft. Sollte es zu einer Fluoreszenz kommen, ist davon auszugehen, dass es sich um einen falsch-positiven Kandidaten handelt. Im Rahmen dieser Arbeit wurde deshalb jeder im BiFC zu prüfende Kandidat mit dem Protein GUS der Positivkontrolle auf Interaktion getestet (Kapitel 3).

Ein niedriges Expressionslevel ist mutmaßlich in schwach oder nicht leuchtenden Interaktionen begründet und kann damit die Ursache für fehlende Signale im immunologischen Nachweis sein. Sind die Bedingungen für die Protein-Protein Interaktion gegeben, so lässt sich vermuten, dass eine Interaktion zwischen P25 und dem cDNA Klon bereits nach wenigen Stunden erfolgt, die aufgrund der langsameren Rekonstitution des Fluorophors mit einer zeitlichen Verzögerung von einigen Stunden bis Tagen im Mikroskop detektierbar wird (Hu et al., 2002; Bhat et al., 2006; Barnard et al., 2007). 
Wie auch in dieser Arbeit gezeigt werden konnte, ist das BiFC System ein leicht anwendbarer Protein-Protein Interaktionsnachweis, das in lebenden Zellen ohne den Einsatz von externen Färbemethoden durchgeführt und innerhalb eines Tages ausgewertet werden kann (Hu et al., 2002; Kerppola, 2006; Kim et al., 2007). Dennoch ist in dieser Studie nicht feststellbar, ob die nicht nachweisbaren Interaktionen aufgrund eines (i) zu niedrigen Expressionsniveaus kaum oder nicht detektierbar waren, (ii) einer Inkompatibilität zwischen Protein und verwendetem Pflanzengewebe vorlag oder (iii) ein negativer Effekt durch die verwendeten A. tumefaciens Bakterien eingetreten ist. Um eventuelle falsch-positive Hefeinteraktionen zwischen P25 und den cDNA Kandidaten wirklich ausschließen zu können, sind weitere Untersuchungen mit einem anderen Protein-Protein Interaktionssystem, z.B. in vitro "GST-pull-down“, wie im Fall des F-box Kandidaten angewandt, unumgänglich.

\subsection{Screening des zweiten (viralen) Pathogenitätsfaktors P26 des BNYVV}

In Ergänzung zu den in den Kapiteln 2-4 dargestellten Arbeiten, wurde eine weitere Durchmusterung der erstellten cDNA Bibliothek vorgenommen. Dafür wurde das Protein P26, welches als zusätzlicher Pathogenitätsfaktor kodierend auf der RNA5 im P-Typ beschrieben und für eine verstärkte Symptomsausprägung bzw. Aggressivität verantwortlich ist, als "bait“ verwendet (Koenig et al., 1997; Heijbroek et al., 1999; Link et al., 2005). Aufgrund eines vermuteten Synergismus zwischen P25 und P26 (Tamada et al., 1996; Link et al., 2005), sowie einer vorhandenen Sequenzhomologie des Aminosäuremotivs 'FRGPGN' (Koenig et al., 1997), sollten die Ergebnisse weitere Rückschlüsse zu dem durchgeführten P25 cDNA Bibliotheksscreen ermöglichen. Die Zielstellung dieser Untersuchung war in Anlehnung an die erfolgreiche Identifizierung von Proteininteraktionen zwischen P25 und Zuckerrübenproteinen die Identifizierung von P26 interagierenden Zuckerrübenproteinen. Daraus sollte ein detaillierteres Verständnis des Zuckerrübe-BNYVV-Pathosystems ermöglicht werden, in dem ähnliche und ggf. weitere Zuckerrübenproteine, die funktionell mit dem Pathogenitätsmechanismus in Zusammenhang gebracht werden können, identifiziert werden. Für die 
Anwendung des P26 wurde zunächst die Autoaktivierung des Proteins überprüft und eine eindeutige Transkriptionsaktivierung von Auxotrophiemarker und Reportergen in dem in dieser Arbeit verwendeten LexA basierenden YTH System detektiert. Diese Beobachtung stimmt mit Ergebnissen aus Untersuchungen in einem Gal4 basierenden System überein (Link et al., 2005). Die Autoren wiesen die transkriptionsaktivierende Domäne in den ersten 55 Aminosäuren des P26 Proteins nach. Durch Alanininsertionsmutagenese des P26 wurden verschiedene Modifikationen des Proteins im N-terminalen Bereich hergestellt (Link et al., 2005). Die von den Autoren zur Verfügung gestellten P26 Mutanten zeigten nach Alanininsertion sowohl im "yeast one-hybrid" als auch im LexA basierenden YTH System keine Autoaktivierung, waren aber weiterhin in der Lage entsprechend dem Wildtyp nekrotische Läsionen mittels Blattinokulation von C. quinoa zu erzeugen. Des Weiteren wurde die subzelluläre Lokalisation der Mutanten untersucht. Der Wildtyp ist vornehmlich im Zellkern der C. quinoa Zellen zu finden. Zwei der verwendeten Kandidatenproteine entsprechen dabei dem Verhalten des P26 Wildtyps und wurden ebenfalls überwiegend im Zellkern detektiert. Die dritte P26 Mutante ist in ihrer Zellkernlokalisation durch die Mutation beeinflusst worden und wurde dementsprechend überwiegend im Cytoplasma nachgewiesen. Diese drei P26 Mutanten wurden für die Durchmusterung der cDNA Bibliothek ausgewählt. Nach mehrmaliger Durchführung der cDNA Bibliothek-Durchmusterung mit allen drei P26 Mutanten konnte kein Hefewachstum und somit keine P26 Interaktion als Ergebnis festgehalten werden. Ein Screening der cDNA Bank mit P25 als Positivkontrolle wurde parallel erfolgreich mitgeführt und ließ darüber methodische Fehler ausschließen. Die Ergebnisse aus der Protein-Protein Interaktion von P26 Mutanten mit der Zuckerrüben cDNA Bibliothek zeigten, dass durch die Herstellung von Alanin inserierten P26 Mutationen die Fähigkeit zur Interaktion mit anderen Proteinen beeinträchtigt ist. Aufgrund der für P26 postulierten Funktion als Pathogenitätsfaktor war eine dem Ergebnis der P25 Bibliotheksdurchmusterung ähnliche Identifizierung von Zuckerrübenproteinen, die mit P26 interagieren zu erwarten. Das Ausbleiben von Proteininteraktionen zwischen dem viralen P26 und der Zuckerrübenbibliothek lässt den Rückschluss zu, das durch die Verwendung von P26-Mutanten, die in ihrer Funktion als Transkriptionsaktivatoren verhindert 
waren, eine essentielle Funktion des P26 deletiert war und damit die Fähigkeit zur Proteininteraktion beeinträchtigt wurde. Das YTH System ist jedoch für den gezielten Nachweis des Ausbleibens einer Interaktion ungeeignet. Um sicherzugehen, dass eine Interaktion mit den P26 Mutanten grundsätzlich ausgeschlossen ist, muss dieses Ergebnis durch ein weiteres, alternatives Protein-Protein Interaktionssystem bestätigt werden.

\subsection{Eine Beteiligung des F-box Kandidaten an der Virusresistenz?}

Resistenzmechanismen gegenüber Pflanzenviren werden verschiedenen Klassen zugeordnet. Diese Mechanismen sind bislang nur teilweise bekannt und werden in der Literatur durch verschiedene Modelle beschrieben. Der mit am besten charakterisierteste Resistenzmechanismus basiert auf dem „RNA silencing“, welches einer nukleinsäurebasierten, pflanzeneigenen "Immunreaktion" entspricht. Auslöser dieses Reaktionsmechanismus ist die Bildung doppelsträngiger RNA (dsRNA) Moleküle (Baulcombe 2004; Filipowicz et al., 2005), die u.a. bei der Virusreplikation von RNA-Viren temporär vorliegen und eine sequenzspezifische Degradation der viralen Nukleinsäure in Pflanzen induzieren kann. Im Gegenzug haben Pflanzenviren eine Abwehrstrategie entwickelt durch die Kodierung von „RNA silencing suppressor" Proteinen (Silhavy und Burgyan, 2004; Voinnet, 2005). Diese werden durch wahrscheinlich jedes Virus mit unterschiedlicher Funktion und Effektivität kodiert (Moissiard und Voinnet, 2004). Charakterisiert wurden z.B. "silencing suppressor" Proteinfunktionen bei PO des beet western yellows virus (Pfeffer et al., 2002), HC-Pro des tobacco etch virus (Anadalakshmi et al., 1998), 16K des tobacco rattle virus (Liu et al., 2002), wie auch dem Hüllprotein CP des turnip crinkle virus (Qu et al., 2003). Eine Funktion als „silencing suppressor“ ließ sich P25 nicht zuschreiben. Die BNYVV Proteine, P14 der RNA2 (Dunoyer et al., 2002) und P31 der RNA4 (Rahim et al., 2007), konnten bereits als solche identifiziert werden. Ein im Rahmen dieser Arbeit zusätzlich nach Voinnet et al. (1999) durchgeführter Agrobakterium vermittelter "silencing suppression assay" schloss P25 als dritten "silencing suppressor" aus (Ergebnisse nicht dargestellt). 
Die Gen-für-Gen Hypothese (Flor, 1971) beschreibt einen weiteren Resistenzmechanismus. Dieser basiert auf der Wechselwirkung des pflanzlichen Resistenzgens $(R)$ mit dem korrespondierenden Avirulenzgen (Avr) des Pathogens. Identifizierte R-Gene wurden in Klassen gruppiert, wobei die größte charakterisiert ist durch in Verbindung auftretende "nucleotide-binding site" (NBS) und "leucine rich-repeat" (LLR) Motive (Hammond-Kosack und Jones, 1997; Martin et al., 2003). Das wohl bekannteste Beispiel für eine monogen vermittelte $R$-Gen Resistenzreaktion ist das $N$-Gen aus Nicotiana glutinosa, welches in Tabak Resistenz gegen das tobacco mosaic virus (TMV) verleiht (Holmes, 1938) durch Auslösung einer Hypersensitiven Reaktion (HR). Durch die HR, wird die Möglichkeit des Virus für Replikation und Ausbreitung eingegrenzt, d.h. auf die Zellen um den Bereich der Lokalläsionen beschränkt (Hammond-Kosack und Jones, 1997; McDowell und Woffenden, 2003). Ebenfalls zu den R-Gen vermittelten Resistenzen zählend, ist die Extreme Reaktion (ER). Bei dieser Resistenz wird angenommen, dass das Virus durch seine nach Infektion der Zelle beginnenden Replikation erkannt wird. Die dadurch aktivierte pflanzliche Abwehrreaktion führt dazu, dass das Virus direkt in dem infizierten Zellbereich an seiner Replikation und der damit verbundenen Ausbreitung gehindert und somit abgetötet wird. Die $R$-Gene $R \times 1$ und $R \times 2$ (Ritter et al., 1991), die nach einem noch immer ungeklärten Mechanismus eine extreme Resistenz gegenüber des potato virus $\mathrm{X}(\mathrm{PVX})$ erzeugen können, stellen ein Beispiel für ER dar (Bendahmane et al., 1997; Bendahmane et al., 1999,).

Neben den dominanten $R$-Genen sind auch rezessive $r$-Gene identifiziert worden. Diese rezessiven Resistenzgene beinhalten Defekte, die zelluläre Prozesse einschränken und die viralen Funktionen "Replikation" und "Zell-zu-Zell Transport" entscheidend beeinträchtigen. Diese Form der Resistenz ist z.B. für die Interaktion des am 5'-Ende der Potyviralen RNA befindlichen Protein VPg ("virus protein, genome linked") mit dem "translational initiation factor" des Wirtes beschrieben worden. "translational initiation factor" elF4E als natürlich vorkommendes Resistenzgen wurde z.B. dem sbm1 gegen pea seed-borne mosaic virus in Erbse (Gao et al., 2004) oder auch pvr1 gegen tobacco etch virus in Paprika (Ruffel et al., 2002) nachgewiesen. 
Eine Resistenz, die sowohl durch ein dominantes, als auch rezessive Resistenzgene kontrolliert wird, liegt unter anderem beim bean common mosaic virus (BCMV) vor (Drijthout, 1978). Das dabei in Phaseolus vulgaris identifizierte dominante I-Gen (Ali, 1950) konnte zusätzlich bei mehr als neun verschiedenen Potyviren identifiziert werden (Fischer und Kyle, 1994). Diese Resistenz gegen BCMV basiert dabei neben dem I-Gen zusätzlich auf rezessiven Genen, die im Wirtsgenom verteilt vorliegen. Die Stärke der Resistenz variiert in Abhängigkeit des Virusstammes, der Umweltbedingungen und kann durch einen Gen-Dosis-Effekt verändert werden. Die Symptome können deshalb in verschiedenen Stärken von ER über systemische Nekrosen bis hin zum Zelltod auftreten (Collmer et al., 2000).

Van der Biezen und Jones (1998) formulierten die „Guard-Hypothese“. Sie besagt, dass die Aktivierung einer Resistenzreaktion durch ein $R$-Gen möglich ist, wenn dieses zusätzlich mit einem weiteren Pflanzenprotein interagiert, welches wiederum mit dem Avr-Gen des Pathogens interagiert. Nach diesem Modell kommt es nicht zu einer direkten physikalischen Interaktion zwischen $\mathrm{R}$ und Avr Protein (McDowell und Woffenden, 2003). Untersuchungen im Rahmen eines YTH Screens mit dem Hüllprotein (CP) des turnip crinkle virus (TCV) als "bait" Protein identifizierten ein TCV-interagierendes Protein (TIP) aus A.thaliana (Ren et al., 2000). Die HRT-vermittelte Resistenz in $A$. thaliana wurde nur beobachtet, wenn TIP und CP-TCV vorlagen und entspräche damit dem Modell der "Guard-Hypothese“.

Der F-box Kandidat, der durch den YTH Screen als Interaktionspartner des Pathogenitätsfaktors P25 identifiziert und in Kapitel 4 detailliert charakterisiert wurde, stellt ein mögliches an der BNYVV Resistenz in Zuckerrübe beteiligtes Protein dar. Dieses F-box Protein induziert sowohl als cDNA-, als auch als VollLängen-Klon eine HR nach transienter Agroexpression in N. benthamiana Blattparenchymzellen. Voll-Längen-Klone des F-box Proteins aus zwei resistenten ( $R z 1$ und $R z 2$ ), sowie einer anfälligen, homozygoten Zuckerrübenlinie zeigten eine P25 Interaktion. Auch durch den Austausch des B-Typs gegen den aggressiveren kalifornischen BNYVV IV-Typ war kein Unterschied in der Hefeinteraktion festzustellen. Aufgrund der Zelltodreaktion war eine Interaktionsüberprüfung im BiFC nicht möglich und wurde deshalb zum einem in einem Gal4-basierenden 
YTH und zum anderen im „in vitro GST-pull-down" als wahre Interaktion bestätigt. Um die hochsignifikante Sequenzhomologie zum „kelch repeat-containing F-box family protein" aus $A$. thaliana zu verifizieren, wurden Interaktionsstudien mit F-box interagierenden Proteinen durchgeführt. F-box ist ein Protein des aus SKP1, Cullin1 und F-box bestehenden SCF-Komplexes, welcher Bestandteil der Ubiquitinierung und somit der Zelldegradation am 26S Proteasom ist. Das im SCF-Komplex vorliegende F-box Protein wurde auf seine Interaktion im Gal4-basierenden YTH mit homologen SKP1 Proteinen aus A. thaliana ASK1 und ASK2 erfolgreich durchgeführt. Somit ist es sicher, dass der identifizierte F-box Kandidat am Ubiquitin-Proteasom System beteiligt ist. Diesbezüglich stellt sich die Frage, ob die Interaktion zwischen F-box und P25 an der BNYVV Resistenz beteiligt und in wie weit mit den zuvor vorgestellten Resistenzmechanismen vereinbar ist. Soosaar et al. (2005) beschreiben den Mechanismus der Ubiquitin-vermittelten Proteindegradation am 26S Proteasom als Resistenzmöglichkeit. Bespiele für F-box Proteine, die am Resistenzmechanismus z.B. an der Auslösung einer HR oder in der systemisch erworbene Resistenz (SAR) beteiligt sind, wurden in der Literatur beschrieben. Dazu zählt SON1 aus A. thaliana, das als F-box Protein SAR regulierende Proteine für den Proteinabbau rekrutiert (Kim und Delaney, 2002), wie auch das ACRE189 aus Tabak, welches für die Auslösung einer Avr9 vermittelten HR gegen Cladiosporum fulvum notwendig ist und in transgenen Tabakpflanzen identifiziert wurde (van den Burg et al., 2008).

Zusätzlich wurden in Kapitel 4 virale F-box Proteine, sowie durch das F-box rekrutierte Virusproteine für die Proteindegradation beschrieben und diskutiert. Die beobachtete HR in N. benthamiana, welche durch F-box induziert wurde, ist durch den Nachweis der Expression von „pathogenesis related“ (PR) Proteinen bestätigt worden.

Die Möglichkeit, dass es sich bei den in diesem Kapitel diskutierten F-box-P25 Interaktionen um eine rezessive Resistenzreaktion handelt, ist weitestgehend ausgeschlossen, da bei diesem Mechanismus die Virustranslation verhindert wird. Für BNYVV wurde beschrieben, dass die für das Virus lebensnotwendigen Funktionen (sogenannte "house keeping functions") auf RNA 1 und 2 kodiert werden (Kapitel 2). Daher ist es naheliegender, dass es sich um eine 
unvollständige Resistenz handeln könnte. Für BNYVV ist bekannt, dass in resistenten Zuckerrübengenotypen zum einen ein monogenes $R z-G e n$, sowie zum anderen mehrere Minorgene vorliegen. Das Auftreten eines aggressiven BNYVV Isolates, das im Imperial Valley, USA entdeckt wurde (Liu et al., 2005, Liu und Lewellen, 2007) führte zur Resistenzüberwindung einer $R z 1$ resistenten Sorte und könnte für eine solche Resistenz Hinweis gebend sein. In diesem Zusammenhang ist es denkbar, dass die Aminosäuretetrade as60-67 (Kapitel 1.2.3. und Kapitel 2), die im amerikanischen Isolat in veränderter Komposition identifiziert und charakterisiert wurde (Acosta-Leal et al., 2008) zu einer verstärkten Expression des P25 führte und somit zur Überwindung der Rz1 Resistenz führt. Diese Hypothese würde einen Rückschluss auf einen Gen-Dosis-Effekt in diesem Zusammenhang zu lassen.

Das Resistenzmodell der Gen-für-Gen Hypothese, welches sich bei vielen pflanzenviralen Infektionen mit einer HR als Symptom äußert, ist z.T. auf die Interaktion BNYVV-Zuckerrübe übertragbar. In der Literatur wurden nekrotische Läsionen in BNYVV resistenten Wildrüben beschrieben, die durch mechanische Blattinokulation hervorgerufen wurden und die Virusreplikation und somit die BNYVV Ausbreitung stark einschränken (Tamada, 2007; Chiba et al., 2008). Des Weiteren könnten auch die in Kapitel 1 und 2 beschriebenen Verbräunungen der Leitbahnen im Rübenkörper nach Virusbefall einen Hinweis auf eine auftretende Abwehrreaktion sein. Die Interaktion von P25-F-box ist aufgrund der in Tabak beschriebenen HR ein Hinweis auf diesen Resistenzmechanismus. Die Domänenanalyse auf Aminosäureebene identifizierte im untersuchten F-box Protein mindestens eine F-box Domäne sowie eine „kelch-repeat“ Domäne. Dabei ist es sicher, dass die am C-Terminus befindliche „kelch-repeat“ Domäne für die Bindung der abzubauenden Zielproteine verantwortlich ist (Cardozo und Pagano, 2004). Durch die Herstellung von F-box Deletionsklonen, die N- bzw. C- terminale Deletionen trugen, konnte ausgeschlossen werden, das P25 mit der Zielprotein-rekrutierenden Domäne interagiert und somit wahrscheinlich nicht vom F-box zum Proteinabbau geführt wird. Diese Beobachtung deckt sich nicht mit der Annahme einer Funktion als $R$-Gen für das F-box im Sinne einer Gen-für-Gen Wechselwirkung zwischen F-box und P25. Auch die Amplifizierung von F-box, sowohl aus anfälligen, wie auch resistenten Zuckerrübenlinien und eines nicht 
nachweisbaren Nukleotidsequenzpolymorphismus zwischen Amplifikaten resistenter und anfälliger Linien, der einen funktionellen Polymorphismus ermöglichen könnte, widerspricht der Gen-für-Gen Hypothese, da funktionelle $R$-Gene nur in resistenten Pflanzen vorliegen. Somit kann vermutet werden, dass der Mechanismus einer monogenen dominanten $R$-Gen vermittelten Resistenz im Sinne der Gen-für-Gen Hypothese für BNYVV nicht in Frage kommt und weitere Faktoren am Resistenzmechanismus beteiligt sein müssen.

Sicher gesagt werden kann, dass es sich bei F-box nicht um ein Rz-Gen handelt, da dieses bei Kartierungsarbeiten durch die Zuckerrübenzüchter (KWS SAAT AG, Einbeck; STRUBE-DIECKMANN GmbH \& Co. KG, Söllingen und Syngenta Seeds $A B$, Landskrona) auf Chromosom 5 lokalisiert wurde. Es ist aber nicht auszuschließen, dass F-box in Form eines Minorgens (Biancardi et al., 2002) eine Funktion in der BNYVV Resistenzreaktion einnimmt. Die Schwierigkeit Rz-Gene zu amplifizieren, zeigten auch die Arbeiten von Lein et al. (2007). Die Autoren versuchten durch die Nutzung von "resistance gene analoges“ (RGA) als Marker und passenden spezifischen Primern aus Zuckerrübe den Rz1 Resistenz Locus genauer zu identifizieren. RGAs sind hoch konservierte Sequenzen, die NBS und LRR Motive beinhalten und somit hohe Homologie zu R-Genen zeigen. Dabei war es möglich eine Anhäufung von RGAs in direkter Nähe zu $R z 1$ zu identifizieren. Der Rz1 Locus blieb dabei weiterhin unbekannt.

$\mathrm{Zu}$ dem in diesem Kapitel 5.5. beschriebenen F-box Protein wurden ein zweites „kelch-repeat“ F-box Protein, sowie ein U-box Protein im YTH Screen identifiziert. Die zwei F-box und das U-box Protein fungieren als E3 Ligase oder als Teil einer solchen. Die wiederholte Identifizierung von 26S-Proteasom-beteiligten Proteinen stärkt die Hypothese der Beteiligung der Ubiquitinierung am P25Wirkmechanismus.

Als möglicher Resistenzmechanismus mit Beteiligung des F-box verbleibt die "Guard“-Hypothese. Dabei stehen verschiedene Interpretationsmöglichkeiten zur Verfügung. Zum einen könnte das Rz-Gen als "guard“ sich das F-box als "guardee" nutzbar machen und es somit nach P25 Interaktion zur Abwehrreaktion der Zuckerrübe kommen. Das setzt allerdings voraus, dass F-box eine direkte Interaktion mit dem $R z$ eingeht. Eine Untersuchung dieser Interaktion steht noch aus und sollte in nachfolgenden Arbeiten bestätigt werden. Alternativ dazu könnte 
das Rz-Gen mit einem bisher noch unbekannten Protein als "guardee" interagieren, welches für die P25 Interaktion das identifizierte F-box Protein benötigt.

Denkbar wäre auch die P25-F-box-Interaktion zugunsten des Virus. In diesem Fall würde P25 eine Resistenzreaktion unterdrücken, indem es eine Interaktion mit Fbox eingeht, um zu unterbinden, dass HR-beteiligte Gene, die vom F-Box zum Zwecke der Auslösung einer HR rekrutiert werden, dem 26S-Proteasom zugeführt werden. Um den Einfluss des F-box auf P25 und damit den Pathogenitätsmechanismus besser zu charakterisieren, sind weitere Analysen des F-box Proteins zukünftig unbedingt erforderlich.

\subsection{Möglichkeiten für die weitere Charakterisierung von P25 interagierenden cDNA Kandidaten}

Die Ergebnisse der vorgestellten Durchmusterung der cDNA Bibliothek erstellt aus einer BNYVV infizierten, resistenten Zuckerrübenlinie mit dem Pathogenitätsfaktor P25 des BNYVV basieren auf Interaktionen von Proteinen. Arbeiten die aus der Literatur zur Diskussion dieser Ergebnisse herangezogen wurden, dienen dabei als Hinweise auf differenziell auftretende Proteine nach BNYVV Infektion. Die Transkriptom- bzw. Proteomstudie von Schmidlin et al. (2008) und Larson et al. (2008) stellen eine gute Diskussionsgrundlage dar. Die Autoren nutzten für ihre Analysen die Infektion anfälliger Zuckerrübengenotypen mit BNYVV, um auf diesem Weg die Expression von Proteinen zu zeigen, die durch Pathogeninduktion auftreten. Schmidlin et al. (2008) führten eine Transkriptionsanalyse durch, in der das Expressionsverhalten von Genen der Zuckerrübenwurzel nach Rizomaniainfektion bestimmt wurde. Identifizierte Kandidaten konnten mit der Ubiquitinierung, dem Zellzyklus, einer Beteiligung am Metabolismus, sowie der Signalabwehr und der Antwort auf oxidativen Stress in Verbindung gebracht werden. Kategorien, in die auch die mit P25 interagierenden Kandidatenproteine dieser Arbeit eingeordnet werden konnten (Kapitel 3, Tabell 1). Larson et al. (2008) identifizierten BNYVV-induzierte Proteomveränderungen der Zuckerrübe. Dabei wurden vorrangig Proteine mit Beteiligung an der systemischen Resistenz, der Veränderung in der 
Phytohormonaktivität, sowie der Symptomentwicklung untersucht. Kandidaten, die im Rahmen der in dieser Arbeit durchgeführten YTH Analysen identifiziert wurden, konnten in vergleichbare funktionelle Kategorien gruppiert werden, wie in den Arbeiten von Schmidlin et al. (2008) und Larson et al. (2008). Die Übereinstimmung dieser funktionellen Gruppierungen identifizierter Transkripte und Proteine in unterschiedlich ausgerichteten Untersuchungen (Larson et al., 2008; Schmidlin et al., 2008 und das in Kapitel 3 verfasste Manuskript) lassen den Rückschluss auf eine Beteiligung allgemeiner, stressbezogener Zellreaktionen der Zuckerrübe auf eine BNYVV Infektion zu. Untersuchungen der gewebespezifischen Transkriptomik, wie von Bellin et al. (2002) durchgeführt, stellen ein wichtiges Hilfsmittel für die u.a. organspezifische Bestimmung von Proteinfunktionen von Zuckerrübengenen dar. Die Autoren identifizierten Transkripte der stressbezogenen Signaltransduktion und bringen deren Expression mit Zellstreckung sowie einem Anstieg des osmotischen Potenzials aufgrund der Zuckerakkumulation in Zusammenhang.

Aus den mit Hilfe des YTH-Screens identifizierten Interaktionen konnten neue Erkenntnisse über die mögliche Beteiligung von Proteinen am Resistenzmechanismus bzw. der Pathogenitätsfunktion des Zuckerrüben-BNYVV Interaktion abgeleitet werden. Insbesondere wurden Hinweise auf mögliche Proteinfunktionen mit Hilfe der Durchführung von Datenbankvergleichen zu Sequenzen bekannter Funktionen abgeleitet (Kapitel 3, Tabelle1). Aufgrund dieser Sequenzhomologien und daraus abgeleiteter potentieller Proteinfunktionen besteht die Möglichkeit, mit P25 interagierende cDNA Kandidaten für weitere Arbeiten auszuwählen. Die für eine genauere Charakterisierung in Frage kommenden Kandidaten sollten anhand ihrer putativen Funktionen Rückschlüsse auf eine mögliche funktionelle Beteiligung an dem Resistenzmechanismus der Zuckerrübe zulassen. Neben dem in dieser Arbeit charakterisierten F-box Protein (Kapitel 4 und 5.3) wurden zwei weitere Kandidaten, ein U-box und ein zweites „kelch-repeat containing F-box“ identifiziert. U-box Proteine gehören wie auch die F-box Proteine zu den E3 Ligasen des Ubiquitinierungsprozesses. Der Unterschied dieser ist darin zu finden, dass F-box eine Komponente der E3 Ligase im SCF-Komplex ist, wohingegen das U-box Protein allein als eine solche fungiert. Die im Folgenden diskutierten cDNA Klone stellen nur einen Teil der möglichen 
Kandidaten dar und gelten aufgrund der in Kapitel 3 diskutierten Eigenschaften als die interessantesten. Die drei am Ubiquitinierungsprozess beteiligten Proteine „kelch-repeat containing F-box" (Nr. 1, 12) sowie der U-box Kandidat (Nr. 24) (Kapitel 3, Tabelle 1, von denen Kandidat Nr.1 bereits detailliert charakterisiert wurde (Kapitel 4), sind aufgrund von durchgeführten Studien als Interaktionspartner pathogener Proteine bzw. als Beteiligte der Ubiquitinierungskaskade bekannt. Neben den bereits in Kaptitel 5.4. erwähnten Beispielen des SON1 aus A. thaliana (Kim und Delaney, 2002) und dem ACRE189 aus Tabak (van den Burg et al., 2008), kann das als F-box identifizierte P0 des Polerovirus, sowie das ACRE276 aus Tabak, welches ein U-box dargestellt als Beispiel herangezogen werden (Yang et al., 2006). F-box, als auch U-box Proteine sind in der Literatur viel beschrieben worden. Dennoch sind die Zielproteine die für die Proteindegradation ausgewählt werden in vielen Hinsichten nach wie vor ungeklärt. Auffallend ist, dass es bei den bisher identifizierten Zielproteinen mehrfach Zielproteine aus Phytohormonsignalwegen zu finden sind. Bekannte F-box Substrate von A. thaliana sind Z.B. das Auxin "Indole-3-acetic acid" (IAA/Aux) als Zielprotein des F-box TIR1 (Dharmasiri et al., 2005; Kepinski und Leyser 2005), die DELLA Proteine als Beteiligte der Gibberellinsynthese und Zielproteine des F-box Proteins SLEEPY1 (McGinnis et al., 2003; Dill et al., 2004), das Protein EIN3 des Ethylensignalweges, welches das Substrat der „EIN3binding F-box" Proteine (EBF1 und EBF2) darstellt (Guo und Ecker, 2003; Potuschak et al., 2003; Gagne et al., 2004), sowie das Zielprotein "timing of cab expression" (TOC1), ein in den zirkadianen Rhythmus involviertes Protein, das vom F-box Protein Zeitlupe (ZTL) rekrutiert wird (Mas et al., 2003; Somers et al., 2004). Zielproteine der U-box Proteine sind ebenfalls weitestgehend ungeklärt, zu den identifizierten Substraten aus $A$. thaliana zählen z.B. RPN12a eine Proteinphosphatase 2A Untereinheit des 19S ribosomalen Partikels als Ziel der U-box Proteine PUB22 und PUB23 (Cho et al., 2008) und Proteine, die u.a. für Proteinfaltung verantwortlich sind, Hsp70 und Hsp90, welche durch das U-box Protein CHIP zur Degradation geführt werden (Luo et al., 2006). Das Protein, dass in dieser Arbeit mit hoher Homologie zu einem U-box Protein identifziert wurde, besitzt unter anderem eine weitere signifikante Homologie zu einem ACRE276-like Protein. ACRE276 wirkt wie zuvor dargestellt als Zelltod auslösendes Protein und 
aufgrund dessen sollte dieser Kandidat in zukünftigen Arbeiten mit berücksichtigt werden. Es wurde beschrieben, dass Pflanzenviren versuchen, ein Ungleichgewicht zwischen Wirts- und Virusproteinen auszugleichen, in dem bestimmte Zielproteine erkannt und anschließend zur Degradation am 26S Proteasom weitergeleitet werden (Banks et al., 2003). Die Interaktionen zwischen P25 des BNYVV und dem Proteasom sind in ihrer Relevanz vollkommen ungeklärt. Denkbar wären zusätzlich zu der in Kapitel 5.4. diskutierten Relevanz für Resistenzmechanismen, das P25 in seiner Funktion die Virusreplikation und dessen Zell-zu-Zell Ausbreitung durch den Proteinabbau der Wirtsproteine positiv beeinflusst wird. (Die nachfolgend angegebene Kandidatennummerierung nimmt Bezug auf die in Kapitel 3 dargestellte Tabelle 1). Der bereits charakterisierte F-box Kandidat Nr.1 (mit einer Länge von 1149bp), zeigte hohe Homologie zum $\mathrm{N}$-Terminus des in der Datenbank identifizierten Kandidaten, der nur ca. 300bp länger war, als der P25 interagierende cDNA Klon. Im entsprechenden Aminosäurevergleich, welcher zur Überprüfung hoch konservierter Domänen genutzt wurde, konnten nur zwei der drei „kelch“ Motive des Datenbankkandidaten für den cDNA Kandidaten identifiziert werden. Die Homologie zum F-box Motiv konnte im cDNA Klon als auch nach Herstellung von zugehörigen Voll-Längen-Klonen von der Proteindatenbank nur bedingt bestätigt werden. Die erwartete F-box Domäne konnte zum einen identifiziert werden, wird aber zum anderen aufgrund des "expected value" als nicht signifikant eingestuft. Dennoch ist davon auszugehen, dass es sich um ein F-box Protein handelt, da die Interaktion mit den Proteinen ASK1 und ASK2 die Funktion als ein solches sicherstellt. Die Sequenzen der beiden weiteren Proteasom beteiligte Kandidaten waren wesentlich kürzer. Der nur 508bp lange zweite F-box Kandidat zeigte zu dem aus der Datenbank identifizierten Kandidat (1428bp) Sequenzhomologie nach den „kelch“ Motiven und nur eine geringe Nukleotidübereinstimmung von ca. 250bp.

Der dritte Kandidat Nr. 24, welcher mit 752bp für eine E3 Ligase kodiert stimmt mit dem C-terminalen Ende, einschließlich dem Stopcodon des Datenbankkandidaten überein. Dabei konnten drei „Armadillo/beta-catenin-like repeats“ (ARM) Motive identifiziert werden. Der über 2000bp lange Datenbank U-box Kandidat 
(NM_102674.3) weist eine weitere „ARM“ Domäne, wie auch ein U-box Motiv signifikant auf.

Insbesondere wurden Hinweise gefunden, dass P25 mit Proteinen interagiert, die am Aufbau und der Funktion des Zytoskeletts beteiligt sind. Für weitere Untersuchungen sind zwei Kandidaten mit signifikanter Homologie zu Aktin aus C. papaya (Nr. 6) bzw. zu „Fiber Annexin“ aus G. hirsutum (Nr. 16) von Interesse. Aktin gehört zu einer Genfamilie, die entwicklungsspezifisch in Pflanzen exprimiert wird (Li et al., 2005). Als Teil des Zytoskeletts ist es für das Zellwachstum verantwortlich. Besonders wichtig ist Aktin in Zellvorgängen, wie Zytoplasmaströmung, Zellwandbildung, Organisation des Endoplasmatischen Retikulums usw. Für diese Vorgänge werden in den zugehörigen Zellregionen Aktinfilamente neu gebildet und das lokale Wachstum somit stimuliert. Aktin, besteht aus Mikrofilamenten, die ähnlich den Mikrotubuli sind und als Einzelfilament oder Bündel auftreten (Staiger und Blanchoin, 2006). In der Literatur wurde beschrieben, dass Pflanzenviren sich das Aktingerüst aus Mikrofilamenten zu Nutze machen und sich somit u.a. durch Plasmodesmen zwischen den Zellen fortbewegen und so eine schnelle Verbreitung in der Pflanze erreichen (Ploubidou und Way, 2001; Haupt et al., 2005). Das in dieser Arbeit identifizierte 400bp große Aktin, welches eine Aktindomäne aufweist, zeigt eine fast vollständige Übereinstimmung mit dem in der Datenbank identifizierten Aktinprotein, welches eine Länge von 579bp aufweist. Dennoch konnte weder Start- noch Stopcodon ermittelt werden.

„Fiber Annexin" wird einer Proteinfamilie zugeordnet, die an Membranprozessen beteiligt ist. Der Aufbau des Annexinproteins zeigt, dass der N-terminale Bereich hoch variabel und für die Bindung an Komponenten des Zytoskeletts verantwortlich ist. Die restliche Sequenz des Annexins besteht aus konservierten Bereichen, die ein, sich mehrfach wiederholendes ca. 70 as-Motiv kodiert. Vor allem spielt Annexin eine entscheidende Rolle im Kalziumtransport, sowie bei der pflanzlichen Stressantwort (Konopka-Postupolska, 2007). Der im YTH Screen identifizierte cDNA Klon mit einer Länge von 564bp kodiert für zwei „Annexin repeats" (ANX). Die in der Datenbank identifizierte homologe Sequenz mit einer Länge von $951 \mathrm{bp}$ zeigt dem gegenüber vier dieser ANX Motive. Die Homologie zwischen diesen beiden Sequenzen liegt mit knapp 400bp im vorderen Teil des 
Datenbankkandidaten, wobei das Startcodon nicht mit abgedeckt wurde. Des Weiteren konnte durch Calvert et al. (1996) gezeigt werden, dass es zu einer Interaktion zwischen Aktin (Nr. 6) und „Fiber Annexin“ (Nr. 16) kommen kann. Aufgrund der Interaktion dieser Kandidaten mit P25 lässt sich vermuten, dass dadurch eine Veränderung des Haarwurzelwachstums hervorgerufen und/oder die Zellwandsynthese beeinflusst wird.

Der cDNA Klon Nr.9 zeigt bei der Datenbankanalyse hochsignifikante Sequenzhomologien zu zwei Datenbankeinträgen. Zum einen wurde das Protein HIP2 identifiziert, welches ebenfalls durch einen YTH Screen als Interaktionspartner des viralen „silencing suppressor" HC-Pro der Potyviren detektiert wurde (Guo et al., 2003). Zum zweiten konnte eine signifikante Sequenzhomologie zum Protein Tortifolia1 aus $A$. thaliana nachgewiesen werden, welchem eine entscheidende Rolle bei der Regulation des gerichteten Zellwachstums zugesprochen wird. Da die im YTH Screen selektierte Sequenz des Kandidaten Nr.9 nur 442bp beträgt, dem gegenüber die Datenbanksequenzen eine Länge von ca. 2500bp aufweisen, konnte die in beiden homologen Sequenzen vorkommenden „HEAT“-Domänen (ARM ähnliche Domänen), welche von der Proteindatenbank als Protein-Protein Interaktionsdomänen beschrieben werden, nicht im cDNA-Klon verifiziert werden, da die übereinstimmende Sequenz von 150 bzw. 250bp sich C-terminal hinter den „HEAT"-Domänen befindet.

Der Kandidat Nr.7 zeigt Sequenzhomologie zum „Leucine rich repeat family protein/extensin family protein" (LRR-Extensin) aus A.thaliana. Schmidlin et al. (2008) führten Expressionsstudien durch und zeigten, dass ein zufällig ausgewähltes Extensin, welches nicht mit dem in dieser Arbeit identifizierten Protein übereinstimmt, in resistenten BNYVV infizierten Material exprimiert wird. LRR-Extensin nimmt eine Schlüsselfunktion bei der Zellwandentwicklung ein (Cassab, 1998), die u.a. durch biotischen und abiotischen Stress induziert werden kann (Takemoto et al., 2001; Merkouropoulos und Shirat, 2003). Der Aufbau der Proteine in der LRR-Extensin-Familie besteht zum einem aus einem leucinreichen, repetitiven auf Aminosäureebene hoch konserviertem Motiv am LRR, welches für Protein-Protein Interaktionen verantwortlich ist, zum anderen aus Extensin, das als Aminosäuredomäne sehr variabel auftritt (Ringli, 2005). LRR-Extensin Gene aus A. thaliana werden u.a. 
spezifisch in der Pollenentwicklung wie auch in vegetativen Geweben spezifisch exprimiert. Zusätzlich wurde durch die Datenbankanalyse der identifizierten LRRExtensin Sequenz ein weiteres LRR-Extensin aus A. thaliana identifiziert, das speziell an der Haarwurzelmorphogenese und der Zellstreckung beteiligt ist. Wie die Untersuchungen von Baumberger et al. (2001) zeigen konnten, verursacht eine LRR-Extensin-Mutation vermehrte Seitenwurzelbildung. Zusammenfassend lässt das Ergebnis der Sequenzhomologievergleiche schlussfolgern, dass durch die Interaktion des P25 mit LRR-Extensin, das LRR-Extensin in A. thaliana am Auftreten der phänotypisch veränderten Seitenwurzelbildung in infizierten Zuckerrüben beteiligt ist. Eine Beteiligung dieser Interaktion an der Virussymptombildung (Wurzelbart durch vermehrte Seitenwurzelbildung) lässt sich ebenfalls vermuten und in Zusammenhang mit der pathogenbezogenen pflanzlichen Stressantwort bringen. Der „LLR/Extensin“ cDNA Kandidat deckt aufgrund seiner Größe von 311bp nur einen kleinen Bereich des 2544bp Datenbankkandidaten ab, der mit 150bp vor der identifizierten LRR Domäne am $\mathrm{N}$-Terminus lokalisiert ist.

P25 zeigte Interaktion mit Phytohormonmetabolismusgenen zu dem auch der Kandidat Nr. 25 zählt. „Nt-iaa deduced protein" auch bekannt als „auxin responsive element" (Dargeviciute et al., 1998). Das Phytohormon Indole-3-acetic acid (IAA) koordiniert viele Wachstums- und Entwicklungsprozesse, wie Zellelongation, Seitenwurzelbildung durch Auxin-vermittelte Änderungen in der Zellteilung, Zellerweiterung und der Zelldifferenzierung. In A. thaliana wurde nachgewiesen, dass der Auxin-Signalweg eine entscheidende Rolle im Ubiquitin-Proteasom-System spielen könnte und somit ebenfalls an der Proteindegradation beteiligt wäre (Gray und Estelle, 2000). Der „Nt-iaa deduced protein" cDNA-Bibliotheksklon mit einer Länge von $751 \mathrm{bp}$ zeigt keinerlei Aminosäuredomänen, wohingegen der Kandidat der Datenbankanalyse mit einer Größe von mehr als 723bp eine Aux/IAA Domäne aufzeigt. Die Homologie dieser beiden Sequenzen beträgt ca. 100bp, die genau in der beschrieben Aux/IAA Domäne zu finden ist, aber nur unvollständig vorliegt und somit nicht im cDNA Klon nachweisbar ist.

Der letzte im Rahmen dieser Diskussion erwähnenswerte Kandidat ist Nr. 27 "Clathrin binding protein". Clathrin ist beteiligt an der Zellteilung und dem 
endocytotischen Weg, sowie an der Bildung von Membraneinstülpungen (PérezGómez und Moore, 2007). Beim rice dwarf virus konnte gezeigt werden, dass dieses Vektorzellen von Insekten mittels Clathrin-abhängiger Endocytose besiedelt (Wei et al., 2007). Des Weiteren wurde von Holstein (2002) beschrieben, dass Clathrin beschichte Vesikel am Wachstum von Haarwurzelzellen beteiligt sind. Die Nutzung der Endocytose als Eintrittsweg des BNYVV mittels P25 könnte in Anlehnung an die Ergebnisse von Wei et al. (2007) vermutet werden und zusätzlich noch durch die Beobachtung von Holstein (2002), womit die Wurzelzellen der Seitenwurzeln der Zuckerrüben verstärkt werden. Der signifikant, homologe Datenbankkandidat (1269bp) des "Clathrin binding protein" zeigte keine konservierten Domänen. Eine Sequenzhomologie mit dem ca. 400bp langen cDNA Kandidaten wurde mit nur knapp 100bp zu Beginn nach dem Startcodon aufgezeigt.

Auf der Basis der identifizierten Kandidaten sind zukünftige, gezielte Charakterisierungen des Resistenzmechanismus im ZuckerrübenBNYVV-Interaktionssystem denkbar. Für eine weiterführende Beschreibung ist es notwendig die zu untersuchenden Kandidatengene als Voll-Längen-Klone zu isolieren, und anschließend im YTH erneut die P25 Interaktionen zu bestätigen. Auch eine Überprüfung dieser Voll-Längen-Klone im BiFC sollte zur Bestätigung der ersten Interaktion hinzugezogen werden. Während für die Kandidaten Nr. 6, 9 und 16 die Interaktion mit P25 im BiFC-Assay bestätigt werden konnte, erfolgte dieser Interaktionsnachweis für die Kandidaten Nr. 7, 12, 24 und 25 bisher noch nicht. Um sicherzugehen, dass es sich um wahre Interaktionskandidaten handelt, sollten diese in einem der bereits erwähnten alternativen Protein-Protein Interaktionsassays, wie z.B. in vitro GST-pull-down oder Co-Immunopräzipitation, bestätigt werden. Der F-box Kandidat Nr.1 (Kapitel 4 und 5.3), welcher aus verschiedenen anfälligen und resistenten Zuckerrübenlinien als Voll-Längen-Klon amplifiziert wurde, ist als Möglichkeit für weitere Arbeiten ebenfalls zu berücksichtigen.

Auf der Grundlage der in dieser Arbeit gewonnenen Erkenntnisse könnten zahlreiche weitere gezielte Untersuchungen (Kapitel 5.6.) anschließen, um die Rolle des Pathogenitätsfaktors P25 und sein Mitwirken bei der Entstehung der beschriebenen Rizomaniasymptome vollständig aufklären zu können. 


\subsection{Ausblick}

Der Phänotyp der BNYVV Resistenz ist gut in der Literatur beschrieben (Tamada et al., 1999). Der damit verbundene Resistenzmechanismus konnte bislang noch nicht aufgeklärt werden (Chiba et al., 2008). Um den vorliegenden BNYVV Resistenzmechanismus in Zuckerrübe und die damit verbundenen Wirkmechanismen des P25 aufdecken zu können, zeigen die in Kapitel 5.4 und 5.5. vorgestellten Kandidaten und methodischen Ansätze eine Möglichkeit für zukünftige Arbeiten. Wenn die in Kapitel 5.4. aufgestellte Hypothese, dass F-box eine Schlüsselfunktion zur Erkennung von P25 in Form des sogenannten "Guardee“ zum Resistenzgen $R z$ ausführt, wäre eine erneute YTH cDNA Bibliothek Durchmusterung eine Möglichkeit, um das Majorresistenzgen auf Chromosom 3 aufzudecken. Bei einem Screening mit F-box als „bait“ ist zu erwarten, dass es zur Interaktion zwischen F-box und Rz2, sowie zwischen F-box und P25 kommen könnte, da das Ausgangsmaterial der vorliegenden Bibliothek eine BNYVV infizierte $R z 2$ resistente Zuckerrübenlinie bildet.

Für die weiteren vorgestellten, unvollständigen cDNA Kandidaten sollten Voll-Längen-Klone, sowohl aus anfälligen, wie auch resistenten homozygoten Zuckerrübenmaterial erstellt werden. Um die bisher vermutete Funktion dieser auch als vollständige Gene zu bestätigen, ist eine Interaktion mit P25 erneut im YTH notwendig. Sollten sich die Hypothesen hinsichtlich der Beteiligung am Resistenzmechanismus von BNYVV bestätigen, ist davon auszugehen, dass es zu Unterschieden bei der Interaktion kommt, d.h. die Interaktionen mit P25 könnten unterschiedlich stark sein bzw. eine Interaktion mit P25 bleibt vollständig aus. Eine Veränderung in der Interaktion könnte bei Beteiligung an der Resistenz auch durch die Verwendung eines anderen P25, z. B. das aggressivere P25-IV detektierbar werden. Da Rz2 im YTH Screen mit P25 nicht identifiziert werden konnte, und somit davon auszugehen ist, dass es sich nicht um ein $R$-Gen im Sinne der Gen-für-Gen Hypothese handelt, kann angenommen werden, dass alle Kandidaten sowohl aus anfälligen, wie auch resistenten Zuckerrüben amplifizierbar sind. Die Beteiligung der Kandidaten am Resistenzmechanismus könnte durch den Nachweis differenzieller Transkriptionsmuster in anfälligen und resistenten, homozygoten Zuckerrüben nach BNYVV Infektion deutlich gemacht werden. Der Nachweis dieser, wäre dann mit genspezifischen Primern mittels 
reverser Transkription und anschließender Polymerase-Ketten-Reaktion aus Gesamt-RNA detektierbar.

Die Herstellung transgener Zuckerrübenpflanzen sollte zur Bestätigung der Beteiligung von Kandidaten (z.B. F-box) am Resistenzmechanismus ebenfalls mit herangezogen werden. Durch die Herstellung von „knock-out“ Transgenen mittels RNA-Interferenz (RNAi) können die bestehenden pflanzeneigenen Gene in ihrer Expression reprimiert werden und so resistente Zuckerrübengenotypen ihre Resistenzeigenschaften verlieren. Diese Untersuchungen könnten dann zeigen, inwieweit das F-box eine generelle Funktion an der HR-Induktion spielt. In diesem Fall würden bei RNAi-vermitteltem F-box „knock-out“ ebenso die monogenen $R$-Gen basierenden Resistenzen gegenüber Heterodera schachtii (Cai et al., 1997; Williamson und Kumar, 2006) und Erysiphe betae (Francis, 2002; Grimmer et al., 2007a) beeinträchtigt werden. Liegt eine spezifische Beteiligung des F-box an der BNYVV-Zuckerrüben-Interaktion vor, sollte keine Beeinträchtigung o.a. monogener $R$-Gen basierender Resistenzen zu beobachten sein. Dem gegenüber steht die Alternative der Überexpression von Kandidaten in anfälligen Zuckerrüben. Überexprimierte Kandidatengene sollten somit zur verstärkten Resistenzreaktion führen. Die Funktionalität dieser beiden transgenen Ansätze kann abschließend durch BNYVV Infektionsversuche unter Gewächshausbedingungen auf Anfälligkeit bzw. Resistenz geprüft werden.

Des Weiteren eröffnen sich durch Genomsequenzierung und -kartierung der Zuckerrüben weiterführende Möglichkeiten. Im Jahr 2004 begann mit „BEET Physical Map" (www.gabi.de) ein Projekt zur Genomentschlüsselung von Zuckerrübe. Ziel des Projektes war die Weiterführung der Entwicklung markergestützter Selektionsverfahren durch die Erstellung einer physikalischen Karte des Zuckerrübengenoms. Zusätzlich wurde im Rahmen dieses GABI-Projektes eine „bacterial artificial chromosome“ (BAC) Bank der Zuckerrübe erstellt. Die neuentwickelte BAC-Bank wurde für die physikalische Kartierung eingesetzt. Die physikalische Karte bietet die Möglichkeit bekannte Marker der Rz Gene des BNYVV zu lokalisieren und als Grundlage für die Sequenzierung heranzuziehen. Die Voraussetzung für diese weiterführenden Arbeiten ist, dass die Karte das Chromosom 3 enthält. Molekulare Markerstudien (z.B. QTL und RAPD) zur Lokalisation der BNYVV Resistenzgene kartierten die Gene auf 
Chromosom 3 (Grimmer et al., 2007b). Der geschätzte Abstand von Rz1 und Rz2 liegt zwischen $20 \mathrm{cM}$ und $35 \mathrm{cM}$ (Scholten et al., 1999; Amiri et al., 2003).

In dem 2008 begonnen GABI-FUTURE Projekt (www.gabi.de) wird die Sequenzierung des gesamten Zuckerrüben Genoms durch BAC-Sequenzierung und "shotgun sequencing" durchgeführt. Nach vollständiger Sequenzierung ist auch möglicherweise die exaktere Zahl der im Zuckerrübengenom vorhandenen Gene bestimmbar, die derzeit auf mindestens 25.000 Gene geschätzt wird (Koch, 2006). Mittels vergleichender Kartierung und unter Berücksichtigung der Zuckerrübensequenz, besteht die Möglichkeit einzelne Gene, z.B. Rz oder sogar komplette Genfamilien detailliert $z u$ bearbeiten. Dafür müssen aufwendige Arbeiten zur Feinkartierung des Chromosom 3 angeschlossen werden, um die Region um die Rz-Gene einzugrenzen. Anschließend wäre die Überprüfung der verbliebenen Gene auf Resistenzvermittelnde Eigenschaften durch die Herstellung von transgenen Pflanzen um ein vielfaches vereinfacht und realisierbar. Anhand von $R z$ Sequenzinformationen aus einer Kollektion von anfälligen und resistenten Zuckerrübenlinien wird es möglich, Nukleotidpolymorphismen zu identifizieren und spezifische Allele mit der Resistenz bzw. Anfälligkeit zu korrelieren. Die Durchmusterung einer Kollektion gibt Hinweise auf vorhandene Sequenzvariation am Resistenzlocus innerhalb der Zuckerrübe. Informationen über die Lokalisation der Polymorphismen innerhalb des Gens (Promotorregion, funktionale Domänen) geben Aufschluss über mögliche Signalketten und liefern so die Möglichkeit, gezielt in der Kaskade des Resistenzmechanismus Veränderungen zu bestimmen. Diese Untersuchungen liefern die Basis für die Entwicklung neuer Resistenzen, da es unklar ist, wie langlebig die bekannten monogenen Resistenzen sind und eine Durchbrechung der Resistenz durch das Pathogen, wie bereits das im US-amerikanischen Imperial Valley aufgetretene BNYVV Isolat, welches die Rz1Resistenz überwinden konnte (Liu und Lewellen, 2007; Pferdmenges und Varrelmann, 2008; Pferdmenges et al., 2008), vorgekommen ist. Im Gegensatz dazu wurde gezeigt, dass die Resistenzen gegen Pflanzenviren länger dauerhaft bleiben, im Vergleich mit anderen Pflanzenpathogenen (Harrison, 2002; GarciaArenal und McDonald, 2003). Als Beispiel dafür steht das monogene $R$-Gen $N$ gegen das TMV, welches bereits in den vierziger Jahren identifiziert wurde und bis heute in resistenten Sorten verwendet wird. 
Für die Sequenzierung des vollständigen Genoms wurde ein anfälliger Zuckerrübengenotyp ausgewählt (persönliche Mitteilung D. Borchardt, KWS SAAT AG, Einbeck). Dieser kann die Grundlage bilden für Vergleiche bezüglich Sequenzpolymorphismen zwischen BNYVV anfälligen und resistenten Zuckerrüben. Dafür wäre es notwendig die Zuckerrübensequenz aus einem resistenten BAC Klon (Chromosom 3) direkt mit der Sequenz eines anfälligen Genotypen zu vergleichen.

Neben den beschriebenen Rz-Genen, die auch als Majorgene bekannt sind, liegen zusätzlich resistenzunterstützende Minorgene für die BNYVV Resistenz im Zuckerrübengenom vor (Biancardi et al., 2002; Gidner et al., 2005). Mit Hilfe der physikalischen Karte sowie der vollständigen Genomsequenz der Zuckerrübe wäre die Identifikation mittels "whole-genome" Assoziationsstudien (Glazier et al., 2002; Aranzana et al., 2005) aller an der Resistenz beteiligten Major- und Minorgene denkbar. Durch die Entschlüsselung aller BNYVV-Resistenz vermittelnden Gene könnte der zugehörige Resistenzmechanismus in seiner Komplexität und Funktionsweise sowie die Wirkungsweise des Pathogenitätsfaktors P25 offengelegt werden.

Die in dieser Arbeit erfolgte Bestimmung von P25 interagierenden Zuckerrübenproteinen führte zur Identifizierung möglicher an der BNYVV Resistenz beteiligten Proteine. Deren funktionelle Charakterisierung bezüglich der Zuckerrüben-BNYVV Interaktion wird durch die derzeit vorangetriebenen Projekte der Rübengenomsequenzierung voraussichtlich erleichtert. 


\section{Zusammenfassung}

Die viröse Wurzelbärtigkeit (Rizomania) ist derzeit und wird voraussichtlich auch für die Zukunft eine der bedeutendsten Pflanzenkrankheiten im weltweiten Zuckerrübenanbau bleiben. Das beet necrotic yellow vein virus (BNYVV), welches durch den bodenbürtigen, biotrophen Plasmodiophoromyceten Polymyxa betae übertragen wird, verursacht die Ausbildung eines Wurzelbartes, der zu hohen Ertrags- und Zuckerverlusten führt. BNYVV aus dem Genus Benyvirus ist ein einzelsträngiges sinnpositives RNA Virus, das in Abhängigkeit seiner Herkunft aus 4-5 stäbchenförmigen Viruspartikeln besteht. Die Krankheit wird zurzeit nur über den Anbau von teilresistenten Genotypen mit monogenen, dominant vererbten Resistenzen ( $R z 1, R z 2, R z 3)$, die auf Chromosom 3 des Zuckerrübengenoms lokalisiert sind, kontrolliert. Diese reduzieren die Virusreplikation in infizierten Haarwurzeln und verhindern die Ausbreitung des Virus in die Hauptwurzel. Im zweiten Teil dieser Arbeit wurde dazu ein Überblick über bekannte Resistenzen in Zuckerrübe, das Schadbild von Rizomania, sowie die Biologie des Erregers gegeben. Im Rahmen der vorliegenden Arbeit sollten unter Nutzung molekularer Testsysteme pflanzliche Genprodukte aus resistenten Zuckerrüben-Genotypen, die mit dem Pathogenitätsfaktor P25 des BNYVV interagieren, isoliert und anschließend funktionell charakterisiert werden, um Hinweise auf pflanzliche Resistenzfaktoren bzw. Zielproteine der Viruspathogenität zu erlangen.

Das von der BNYVV RNA3 kodierte Genprodukt P25 ist für die Translokation des Virus im Wurzelsystem, die Ertragsbeeinflussung und die Symptomausprägung in anfälligen Genotypen verantwortlich. Die der Wirt-Pathogen Interaktion zugrunde liegenden Funktionen des Pathogenitätsfaktors P25 sind bisher unbekannt. Sicher ist, dass P25 eine "Shuttle“-Funktion besitzt, durch die es dem Protein in infizierten Zellen möglich ist, sich zwischen Zellkern und Cytoplasma transportiert zu werden. Zur Identifizierung von Proteinen der Zuckerrübe, die an der möglichen Interaktion mit P25 beteiligt sind, wurde ein LexA-basiertes „Yeast Two-Hybrid“ (YTH) System als Protein-Protein Interaktionsassay gewählt. Dieser besteht aus zwei voneinander unabhängigen Transkriptionsfaktoren LexA und B42, die mittels Proteininteraktion als Fusionskomplex die Interaktionsbestätigende Hefetranskription aktiviert. 
Eine aus Wurzel- und Blatt-Gesamt-RNA erstellte cDNA-Bibliothek eines Rz2resistenten Zuckerrübengenotyps wurde auf Proteininteraktionen mit P25 durchmustert. Nach Durchführung des YTH Screens wurden 450 Kandidaten auf Transkriptionsautoaktivierung und P25 Interaktion überprüft und falsch-positive Reaktionen ausgeschlossen. Abschließend verblieben 36 Kandidatengene, deren Nukleotidsequenzen mittels Datenbanksuche auf Homologie zu Sequenzen mit bekannten Funktionen analysiert wurden. Die Aminosäuresequenzen wurden mit Hilfe einer Datenbank für die Identifizierung von Proteindomänen auf konservierte funktionelle Domänen analysiert. Siebenundzwanzig der 36 Kandidaten wiesen signifikante Homologie zu Sequenzen mit bekannter bzw. putativer Funktion auf und ermöglichten eine Einteilung der Kandidatengene in funktionelle Kategorien. Dabei waren jene Kandidaten, die eine mögliche funktionelle Beteiligung an der pflanzlichen Erkennung des viralen Pathogenitätsfaktors P25, der Ubiquitinierung, dem Phytohormonstoffwechsel oder dem Zellwand- und Zytoskellettaufbau haben von besonderem Interesse. Um sicherzustellen, dass die nachgewiesenen Interaktionen des YTH Screen keine falsch-positiven waren, wurden diese P25 Interaktionen mittels eines in planta „bimolecular fluorescence complementation assay“ (BiFC) überprüft. Als Resultat des BiFC konnte die Interaktion von zehn Kandidaten bestätigt werden. Die Ergebnisse des YTH Screens und der BiFC Studie sind im dritten Teil beschrieben.

Im vierten Teil der Arbeit erfolgte die detaillierte Charakterisierung eines vielversprechenden, im cDNA-Bibliothekscreen identifizierten Kandidaten. Dieser wurde aufgrund des Auftretens einer nekrotischen Blattreaktion im Rahmen der BiFC Analyse ausgewählt. In der Datenbankanalyse wies der Kandidat eine signifikante Homologie zu einem „kelch repeat-containing F-box“ Protein aus $A$. thaliana auf. Eine Beteiligung dieses, zu einer Genfamilie gehörenden Kandidatengens, an der Resistenzreaktion ist denkbar, da pflanzliche F-box Proteine an der Rekrutierung von Transkriptionsfaktoren und der Induktion der Resistenzreaktion beteiligt sind. Diese selektierten und mit Ubiquitin markierten Proteine werden dem 26S Proteasom zur Degradation zugeführt. Die vollständige kodierende Sequenz des F-box Kandidaten wurde aus zwei resistenten und einer anfälligen Zuckerrübenlinie isoliert. Anhand von Sequenzvergleichen konnten Polymorphismen gezeigt werden. Dabei wurden keine Unterschiede in den 
bekannten Proteindomänen zwischen den Kandidaten identifiziert, des weiteren konnte die Proteinexpression unter induzierten konstitutiven Bedingungen für den anfälligen als auch die resistenten Kandidaten nachgewiesen werden. Die F-box Kandidaten haben eine Interaktion mit P25 im YTH gezeigt, sowie eine Hypersensitive Reaktion (HR) in Tabak ohne Unterschied zwischen anfälligem und resistentem Ursprung für alle drei F-box Kandidaten induziert. Zusätzlich wurde der F-box Kandidat in einem zweiten YTH System, welches auf dem Transkriptionsfaktor Gal4 basiert, sowie einem in vitro Interaktionsnachweis dem Glutathion-S-Transferase "Pull-down" auf P25 Interaktion getestet und diese bestätigt.

Aufgrund einer Zelltodreaktion, die bei der Interaktion des P25 mit dem unvollständigen F-box Protein im BiFC auftrat, wurde die induzierte Expression von verschiedenen „pathogenesis related proteins“ in Tabak überprüft und somit die Induktion einer HR durch das F-box Kandidatengen nachgewiesen. Für eine Bestätigung, dass es sich bei diesem charakterisierten Kandidaten tatsächlich um ein F-box Protein handelt, wurden im YTH System Interaktionen mit ausgewählten Proteinen des sogenannten SCF-Komplexes, einer E3 Ligase vorgenommen. Dieser Komplex des Proteasoms nimmt die Erkennung von zu degradierenden Proteinen vor und leitet anschließend ihren Abbau durch das 26S Proteasom ein. Von diesem aus SKP1, Cullin und F-box bestehenden Komplex wurden orthologe SKP1 Proteine aus $A$. thaliana (ASK1, ASK2) auf Interaktionen mit dem F-box im Gal4-basierten YTH System untersucht und erfolgreich bestätigt. Die identifizierten F-box Proteine beinhalten zum einem eine „F-box" Domäne zum andere zwei "kelch-repeat" Motive. Um die Funktionen dieser detaillierter zu charakterisieren, wurden Deletionsmutanten des F-box Kandidaten erstellt. Dafür wurde das F-box Protein in seine funktionellen Domänen „F-box“ und „kelch repeats“ geteilt und auf Interaktion in Hefe, sowie Zelltodreaktion mittels Agroexpression analysiert. Die hergestellten Deletionsmutanten zeigten weder eine Interaktion im YTH System mit P25 noch eine Zelltodreaktion in Blattparenchymzellen von Tabak. Die beschriebenen Ergebnisse deuten daraufhin, dass die Anwesenheit aller Domänen des F-box Proteins für eine P25 Interaktion sowie die Auslösung von HR notwendig ist. Eine detaillierte Darstellung der Untersuchungen ist im vierten Teil dieser Arbeit zusammengestellt. 
Um eine mögliche funktionelle Beteiligung von den in dieser Arbeit identifizierten Kandidaten an der pflanzlichen Erkennung des viralen Pathogenitätsfaktors P25 zu charakterisieren, stellen weitere YTH Analysen eine Möglichkeit dar. 


\section{Literaturverzeichnis}

Abe H., Tamada T. (1986) Association of beet necrotic yellow vein virus with isolates of Polymyxa betae Keskin. Annual Phytopathological. Society. Japan 52, 235-247

Acosta-Leal R., Fawley M.W., Rush C.M. (2008) Changes in the intraisolate genetic structure of Beet necrotic yellow vein virus populations associated with plant resistance breakdown. Virology, 20, 60-68.

Alberts B. (1998) The cell as a collection of protein machines: preparing the next generation of molecular biologists. Cell, 92, 291-294.

Ali M.A. (1950) Genetics of resistance to the bean common mosaic virus in the bean (Phaseolus vulgaris L.). Phytopathology, 40, 69-79.

Amiri R., Moghaddam M., Mesbah M., Sadeghian S.Y., Ghannadha M.R., Izadpanah K. (2003) The inheritance of resistance to Beet necrotic yellow vein virus (BNYVV) in $B$. vulgaris subsp. maritima, accession WB42: Statistical comparisons with Holly-1-4. Euphytica, 132, 363-373.

Anadalakshmi R., Pruss G.J., Ge X., Marathe R., Mallory A.C., Smith T.H., Vance V.B. (1998) A viral suppressor of gene silencing in plants. Proceedings of the National Academy of Sciences USA, 95, 13079-13084.

Aranzana M,.J, Kim S., Zhao K., Bakker E., Horton M., Jakob K., Lister C., Molitor J., Shindo C., Tang C., Toomajian C., Traw B., Zheng H., Bergelson J., Dean C., Marjoram P., Nordborg M. (2005) Genome-Wide Association Mapping in Arabidopsis Identifies Previously Known Flowering Time and Pathogen Resistance Genes. PloS Genetics, 1, 531-539.

Aronheim A, Zandi E, Hennemann H, Elledge SJ, Karin M. (1997) Isolation of an AP-1 repressor by a novel method for detecting protein-protein interactions. Molecular and Cellular Biology, 6, 3094-102.

Asher M.J.C. (1993) The sugar beet crop. In: Cooke, D.A. \& Scott, R.K. (eds), Science into practice. Chapman \& Hall, London, 311-346.

Bader GD, Heilbut A, Andrews B, Tyers M, Hughes T, Boone C. (2003) Functional genomics and proteomics: charting a multidimensional map of the yeast cell. Trends in Cell Biology, 7, 344-356.

Banks L., Pim P., Thomas M. (2003) Viruses and the 26S proteasome: hacking into destruction. Trends in Biochemical Sciences, 28, 452-459.

Barnard E., McFerran N.V., Nelson J., Timson D.J. (2007) Detection of proteinprotein interactions using protein-fragment complementation assays (PCA). Current Proteomics, 4, 12-27. 
Barzen E., Mechelke W., Ritter E., Schulte-Kappert E., Salamini F. (1992) RFLP markers for sugar-beet breeding: chromosomal limkage maps and location of major genes for rhizomania resistance, monogermy and hypocotyl colour. Plant Journal, 2, 601-611.

Baulcombe D. (2004) RNA silencing in plants. Nature, 431, 356-363.

Baumberger N., Ringli C., Keller B. (2001) The chineric leucine-rich repeat/extensin caell wall protein $L R X 1$ is required for root hair morphogenesis in Arabidopsis thaliana. Genes \& Development, 15, 28-39.

Becker H. (1993) Pflanzenzüchtung. Verlag Ulmer, Stuttgart.

Bellin D., Weber M., Theis T., Schulz B., Weisshaar B., Schneider K. (2002) EST sequencing, annotation and macroarray Transcriptome analsysis identify preferentially root-expressed genes in sugar beet. Plant Biology, 4, 700-710.

Bendahmane A., Kanyuka K., Baulcombe D.C. (1999) The $R x$ gene from potato controls separate virus resistance and cell death responses. Plant Cell, 11, 781-792.

Bendahmane M., Fitchen J.H., Zhang G., Beachy R.N. (1997) Studies of coat protein-mediated resistance to tobacco mosaic tobamovirus: correlation between assembly of mutant coat proteins and resistance. Journal of Virology, 71, 7942-7950.

Bendixen C., Gangloff S., Rothstein R. (1994) A yeast mating-selection for detection of protein-protein interactions. Nucleic Acids Research, 22, 17781779.

Bhat R.A., Lahaye T., Panstruga R. (2006) The visible touch: in planta visualization of protein-protein interactions by fluorophore-based methods. Plant Methods, 2, 12.

Biancardi E., Lewellen R.T., De Biaggi M., Erichsen A.W., Stevanato P. (2002) The origin of rhizomania resistance in sugar beet. Euphytica, 127, 383-397.

Bongiovanni G.C., Lanzoni L. (1964) La rizomania della bietola. Progresso Agricolo, 2, 209-220.

Bosemark N.O. (1993) Genetics and breeding. Cooke DA, Scott RK (eds.) The Sugar Beet Crop: Science into Practice. Chapman and Hall, London, 67119.

Bracha-Drori K., Shichrur K., Katz A., Oliva M., Angelovici R., Yalovsky S., Ohad N. (2004) Detection of protein-protein interactions in plants using bimolecular fluorescence complementation. Plant Journal, 40, 419-427. 
Bundessortenamt (2008) Beschreibende Sortenliste Getreide, Mais Ölfrüchte Leguminosen (großkörnig) Hackfrüchte (außer Kartoffeln), Bundessorten, Hannover, Deutschland

Cai D., Kleine M., Kifle S. Harloff H.-J., Sandal N.N., Marcker K.A. Marcker Klein-Lankhorst R.M., Salentijn E.M.J., Lange W., Stiekema W.J., Wyss U., Grundler F.M.W., Jung C. (1997) Positional cloning of a gene for nematode resistance in sugar beet. Science, 275, 832-834.

Calvert C.M., Gant S.J., Bowles D.J. (1996) Tomato annexins p34 and p35 bind to F-actin and display nucleotide phosphodiesterase activity inhibited by phospholipid binding. Plant Cell, 8, 333-342.

Canova A. (1959) Appunti di patologia della barbabietola. Informatore Fitopatologico, 20, 390-396.

Cardozo T., Pagano M. (2004) The SCF ubiquitin ligase: Insights into a molecular machine. Nature Reviews Molecular Cell Biology, 5, 739-751.

Cassab G.I. (1998) Plant cell wall proteins. Annual Reviews of Plant Physiology and Molecular Biology, 49, 281-309.

Causier B., Davies B. (2002) Analysing protein-protein interactions with the yeast two-hybrid system. Plant Molecular Biology, 50, 855-870.

Chiba S., Miyanishi M., Andika I.B., Kondo H., Tamada T. (2008) Identification of amino acids of the beet necrotic yellow vein virus p25 protein required for induction of the resistance response in leaves of Beta vulgaris plants. Journal of General Virology, 89, 1314-1323.

Chien C.-T., Bartel P.L., Sternglanz R., Fields S. (1991) The two-hybrid system: A method to identify and clone genes for proteins that interact with a protein of interest. Proceedings of the National Academy of Sciences USA, 88, 9578-9582.

Cho S.K., Ryu M.Y., Song C., Kwak J.M., Kima W.T. (2008) Arabidopsis PUB22 and PUB23 Are Homologous U-Box E3 Ubiquitin Ligases That Play Combinatory Roles in Response to Drought Stress. Plant Cell, 20, 18991914.

Colas P., Brent R. (1998) The impact of two-hybrid and related methods on biotechnology. Trends in Biotechnology, 16, 355-363.

Collmer C.W., Marston M.F., Taylor J.C., Jahn M. (2000) The I gene of bean: a dosage-dependent allele conferring extreme resistance, hypersensitive resistance, or spreading vascular necrosis in response to the potyvirus Bean common mosaic virus. Molecular Plant Microbe Interactions, 13, 1266-1270. 
Commandeur U., Jarausch W., Li Y., Koenig R., Burgermeister W. (1991) cDNAs of beet necrotic yellow vein virus RNAs 3 and 4 are rendered biologically active in a plasmid containing the cauliflower mosaic virus $35 \mathrm{~S}$ promoter. Virology 185, 493-495.

Dang C.V., Barret J., Villa-Garcia M., Resar L.M., Kato G.J., Fearon E.R. (1991) Intreacellular leucine zipper interactions suggest c-Myc heterooligomerization. Molecular Cell Biology, 11, 954-962.

Dargeviciute A., Roux C., Decreux A., Sitbon F., Perrot-Rechenmann C. (1998) Molecular cloning and expression of the early auxin-responsive Aux/IAA gene family in Nicotiana tabacum. Plant Cell Physiology, 39, 9931002.

de Bock T.S.M. (1986) The genus Beta: domestication, taxonomy, and interspecific hybridization for plant breeding. Acta Horticulturae, 182, 335343.

de Virgilio M., Kiosses W.B., Shattil S.J. (2004) Proximal, selective, and dynamic interactions between integrin alpha II beta 3 and protein tyrosine kinases in living cells. Journal of Cell Biology, 165, 305-311.

Dharmasiri N., Dharmasiri S., Estelle M. (2005) The F-box protein TIR1 is an auxin receptor. Nature, 435, 441-445.

Dill A., Thomas S.G., Hu J., Steber C.M., Sun T.P. (2004) The Arabidopsis Fbox protein SLEEPY1 targets gibberellin signaling repressors for gibberellin-induced degradation. Plant Cell, 16, 1392-1405.

Draycott P. (1991) Sugar beet. Verlag: Blackwell.

Drijfhout E. (1978) Genetic interaction between Phaseolus vulgaris and Bean common mosaic virus with implications for strain identification and breeding for resistance. Agric. Res. Rep. 872

Dunoyer P., Pfeffer S., Fritsch C., Hemmer O., Voinnet O., Richards K.E. (2002) Identification, subcellular localization and some properties of a cysteine-rich suppressor of gene silencing encoded by peanut clump virus. Plant Journal, 29, 555-567.

Fields S., Song O. (1989) A novel genetic system to detect protein-protein interactions. Nature, 340, 245-246.

Filipowicz W., Jaskiewicz L., Kolb F.A., Pillai R.S. (2005) Posttranscriptional gene silencing by siRNAs and miRNAs. Current Opinion in Structural Biology, 15, 331-341.

Fisher M.L., Kyle M.M. (1994) Cosegregation of phenotypically similar dominant responses to nine potyviruses. Theoretical and Applied Genetics, 89, 81823. 
Flor H.H. (1971). Current status of the gene-for-gene concept. Annual Reviews of Phytopathology, 9, 275-296.

Ford-Lloyd B.V., Williams A.L.S., Willams J.T. (1975) A revision of Beta section Vulgares (Chenopodiaceae), with new light on the origin of cultivated beets. Bot. J. Linn. Soc., 71, 89-102.

Francis S. (2002) Sugar-beet powdery mildew (Erysiphe betae). Molecular Plant Pathology, 3, 119-124

Freemont P.S. (2000) RING for destruction? Current Biology, 10, R84-87.

Frommer W., Ninnemann O. (1995) Heterologous expression of genes in bacterial, fungal, animal and plant cells. Annual Reviews of Plant Physiology and Plant Molecular Biology, 46, 419-444.

Gagne J.M., Smalle J., Gingerich D.J., Walker J.M., Yoo S.D., Yanagisawa S., Vierstra R.D. (2004) Arabidopsis EIN3-binding F-box 1 and 2 form ubiquitin-protein ligases that repress ethylene action and promote growth by directing EIN3 degradation. Proceedings of the National Academy of Sciences USA, 101, 6803-6808.

Gao Z., Johansen E., Eyers S., Thomas C.L., Noel Ellis T.H., Maule A.J. (2004) The potyvirus recessive resistance gene, sbm1, identifies a novel role for translation initiation factor elF4E in cell-to-cell trafficking. Plant Journal, 40, 376-385.

Garcia-Arenal F., McDonals B.A. (2003) An analysis of durability of resistance to plant viruses. Phytopatholoy, 93, 941-952.

Gidner S., Lennefors B.L., Nilsson N.O., Bensefelt J., Johansson E., Gyllenspetz U., Kraft T. (2005) QTL mapping of BNYVV resistance from the WB41 source in sugar beet. Genome, 48, 279-285.

Goodin M.M., Zaitlin D., Naidu R.A., Lommel S.A. (2008) Nicotiana benthamiana: Its history and future as a model for plant-pathogen interactions. Molecular Plant Microbe Interactions, 21, 1015-1026.

Glazier A.M., Nadeau J.H., Aitman T.J. (2002) Finding Genes That Underlie Complex Traits. Genetics, 298, 2345-2349.

Gray W.M., Estelle I. (2000) Function of the ubiquitin-proteasome pathway in auxin response. Trends in Biochemical Sciences, 25, 133-138.

Grimmer M.K., Bean K.M.R., Asher M.J.C. (2007a) Mapping of Wve resistance genes to sugar-beet powdery mildew using AFLP and anchored SNP markers. Theoretical and Applied Genetics, 115, 67-75. 
Grimmer M.K., Trybush S., Hanley S., Francis S.A., Karp A., Asher M.J.C. (2007b) An anchored linkage map for sugar beet based on AFLP, SNP and RAPD markers and QTL mapping of a new source of resistance to Beet necrotic yellow vein virus. Theoretical and Applied Genetics, 114, 11511160.

Guo H., Ecker J.R. (2003) Plant responses to ethylene gas are mediated by SCF(EBF1/EBF2)-dependent proteolysis of EIN3 transcription factor. Cell, 115, 667-677.

Guo D., Spetz C., Saarma M., Valkonen J.P. (2003) Two potato proteins, including a novel RING finger protein (HIP1), interact with the potyviral multifunctional protein HCpro. Molecular Plant Microbe Interactions, 16, 405-410.

Gyuris J., Golemis E., Chertkov H., Brent R. (1993) Cdi1, a human G1 and S phase protein phosphatase that associates with Cdk2. Cell, 75, 791-803.

Haeberlé A.M., Stussi-Garaud C. (1995) In situ localization of the non-structural protein P25 encoded by beet necrotic yellow vein virus particles. Archives of Virology, 76, 643-650.

Hammond-Kosack K.E., Jones J.D.G. (1997) Plant disease resistance genes. Annual Reviews in Plant Physiology and Plant Molecular Biology, 48, 575607.

Harju V.A., Mumford R.A., Bockley A., Boonham N., Clover G.R.G. (2002) Occurence in the United Kingdom of beet necrotic yellow vein virus isolates which contain RNA 5. Plant Pathology, 51, 811.

Harrison B.D. (2002) Virus variation in relation to resistance-breaking in plants. Euphytica, 124, 181-192.

Haupt S., Cowan G.H., Ziegler A., Roberts A.G., Oparka K.J., Torrance, L. (2005) Two plant-viral movement proteins traffic in the endocytic recycling pathway. Plant Cell, 17, 164-181.

Heijbroek W., Musters P.M.S., Schoone A.H.L. (1999) Variation in pathogenicity and multiplication of beet necrotic yellow vein virus (BNYVV) in relation to the resistance of sugar-beet Cultivars. European Journal of Plant Pathology, 105, 397-405.

Hengen P.N. (1997) Methods and reagents, false positives from the yeast two hybrid system Trends in Biochemical Sciences, 22, 33-34.

Hoffmann G.M., Nienhaus F., Poehling H.-M., Schönbeck F., Weltzien H.C., Wilbert H. (1994) Lehrbuch der Phytomedizin Vol. 3 edn.: Blackwell Wissenschafts-Verlag $\mathrm{GmbH}$. 
Holmes F.O. (1938) Inheritance of resistance to tobacco mosaic disease in tobacco. Phytopathology, 28, 553-561.

Holstein S.E. (2002) Clathrin and plant endocytosis. Traffic, 3, 614-620.

Hook B., Bernstein D., Zhang B., Wickens M. (2005) RNA-protein interactions in the yeast three-hybrid system: affinity, sensitivity, and enhanced library screening. RNA, 11, 227-233.

Hu C.D., Chinenov Y., Kerppola T.K. (2002) Visualization of interactions among bZIP and Rel family proteins in living cells using bimolecular fluorescence complementation. Molecular Cell, 9, 789-798.

Hu C.D., Kerppola T.K. (2003) Simultaneous visualization of multiple protein interactions in living cells using multicolor fluorescence complementation analysis. Nature Biotechnology, 21, 539-545.

Hui Liu B. ed (1998) QTL mapping: introduction, 375-386.

Hull R. ed (2002) Matthews' Plant Virology 4th edn. San Diego ; London [u.a.] Academic Press.

Jach G., Pesch M., Richter K., Frings S., Uhrig J.F. (2006) An improved mRFP1 adds red to bimolecular fluorescence complementation. Nature Methods, $\mathbf{3}$, 597-600.

Jaeger S., Eriani G., Martin F. (2004) Results and prospects of the yeast threehybrid system. FEBS Letters, 556, 7-12.

Jiménez J.A., Rodríguez D., Calvo A.P., Mortensen L.C., Nicolás G., Nicolás C. (2005) Expreesion of a transcription factor (FsERF1) involved in ethylene signalling during the breaking of dormancy in Fagus sylvatica seeds. Physiologia Plantarum, 125, 373-380.

Jiménez I., López L., Alamillo J.M., Valli A., García J.A. (2006) Identification of a plum pox virus $\mathrm{Cl}$-interacting protein from chloroplast that has a negative effect in virus infection. Molecular Plant Microbe Interactions, 19, 350-358.

Jin Y., Ma D., Dong J., Jin J., Li D., Deng C., Wang T. (2008) HC-Pro Protein of Potato Virus Y Can Interact with Three Arabidopsis 20S Proteasome Subunits In Planta. Journal of Virology, 81, 12881-12888.

Jin Y., Ma D., Dong J., Li D., Deng C., Jin J., Wang T. (2007) The HC-pro protein of potato virus $Y$ interacts with NtMinD of tobacco. Molecular Plant Microbe Interactions, 20, 1505-1511.

Johansson E. (1985) Rhizomania in sugar beet - a threat to beet growing that can be overcome by plant breeding. Sveriges Utsädesförenings Tidskrift 95, 115-121. 
Joung J.K., Ramm E.I., Pabo C.O. (2000) A bacterial two-hybrid selection system for studying protein-DNA and protein-protein interactions. Proceedings of the National Academy of Sciences USA, 97, 7382-7387.

Jupin I., Guilley H., Richards K.E., Jonard G. (1992) Two proteins encoded by beet necrotic yellow vein virus RNA 3 influence symptom phenotype on leaves. E.M.B.O. Journal, 11, 479-488.

Jupin I., Tamada T., Richards K. (1991) Pathogenesis of beet necrotic yellow vein virus. Virology, 2, 421-488.

Kaelin W.G., Pallas D.C., Decaprio J.A., Kaye F.J., Livingston D.M. (1991) Identification of Cellular Proteins That Can Interact Specifically with the T/E1a-Binding Region of the Retinoblastoma Gene-Product. Cell, 64, 521532.

Kepinski S., Leyser O. (2005) The Arabidopsis F-box protein TIR1 is an auxin receptor. Nature, 435, 446-451.

Kerppola T.K. (2006) Visualization of molecular interactions by fluorescence complementation. Molecular and Cellular Biology, 7, 449-456.

Kerppola T.K. (2008) Bimolecular fluorescence complementation (BiFC) analysis as a probe of protein interactions in living cells. Annual Reviews of Biophysics, 37, 465-487.

Keskin B. (1964) Polymyxa betae N.Sp., a Parasite in the Roots of Beta Vulgaris Tournefort, Particularly during the Early Growth of the Sugar Beet. Archives of Microbiology, 49, 348-374.

Kim H.S., Delaney T.P. (2002) Arabidopsis SON1 is an F-box protein that regulates a novel induced defense response independent of both salicylic acid and systemic acquired resistance. Plant Cell, 14, 1469-1482.

Kim M.H., Roh H.E., Lee M.N., Hur M.W. (2007) New Fast BiFC Plasmid Assay System for in Vivo Protein-Protein Interactions. Cellular Physiology and Biochemistry, 20, 703-714.

Koch G. (2006) Genetisch-züchterische Grundlagen des Ertragspotenzials von Zuckerrüben. Zuckerindustrie, 131, 32-38.

Koenig R., Kastirr U., Holtschulte B., Deml G., Varrelmann M. (2008) Distribution of various types and P25 subtypes of Beet necrotic yellow vein virus in Germany and other European countries. Archives of Virology, 153, 2139-2144.

Koenig R., Burgermeister W. (1989) Mechanical inoculation of sugarbeet roots with isolates of beet necrotic yellow vein virus having different RNA compositions. Journal of Phytopathology, 124, 249-255. 
Koenig R., Haeberlé A.M., Commandeur U. (1997) Detection and characterization of a distinct type of beet necrotic yellow vein virus RNA 5 in a sugar beet growing area in Europe. Archives of Virology, 142, 1499-1504.

Koenig R., Jarausch W., Li Y., Commandeur U., Burgermeister W., Gehrke M., Luddecke P. (1991) Effect of recombinant beet necrotic yellow vein virus with different RNA compositions on mechanically inoculated sugarbeets. Journal of General Virology, 72, 2243-2246.

Koenig R., Lennefors B.L. (2000) Molecular analyses of European A, B and P type sources of Beet necrotic yellow vein virus and detection of the rare $P$ type in Kazakhstan. Archives of Virology, 145, 1561-1570.

Koenig R., Lüddecke P., Haebberle A. (1995) Detection of Beet necrotic yellow vein virus strains, variants and missed infections by examining single-strand conformation polymorphisms of immunocapture RT-PCR products. Journal of General Virology, 76, 2051-2055

Koenig R. Stein, B. (1990) Distribution of beet necrotic yellow vein virus in mechanically inoculated sugar beet plantlets of cultivars with different degrees of rhizomania resistance. Proceedings of the First Symposium of the International Working Group of Fungal Vectors, Germany, 87-90

Kole C. ed (2007) Genome Mapping and Molecuar Breeding in Plants, Vegetables, Springer-Verlag

Konopka-Postupolska D. (2007) Annexins: putative linkers in dynamic membrane-cytoskeleton interactions in plant cells. Protoplasma, 230, 203215.

Kraemer B., Zhang B., Sengupta D., Fields S, Wickens M. (2000) Using the yeast three-hybrid system to detect and analyze RNA-protein interactions. Methods in Enzymology, 328, 297-321.

Kraft T. (2001) Molecular markers - where are we today? Proc. IIRB 64th Cong. Bruges, Belgium, 159-166.

Kruse M., Koenig R., Hoffmann A., Kaufmann A., Commandeur U. (1994) Restriction fragment length polymorphism analysis of reverse transcriptionPCR products reveals the existence of two major strain groups of Beet necrotic yellow vein virus. Journal of General Virology, 75, 1835-1842.

Kuroda K., Kato M., Mima J., Ueda M. (2006) Systems for the detection and analysis of protein-protein interactions. Applied Microbiology and Biotechnology, 71, 127-136.

Lalonde S., Ehrhardt D.W., Loque D., Chen J., Rhee S.Y., Frommer W.B. (2008) Molecular and cellular approaches for the detection of proteinprotein interactions: latest techniques and current limitations. Plant Journal, 53, 610-635. 
Larson L.L., Wintermantel W.M., Hill A., Fortis L., Nunez A. (2008) Proteome changes in sugar beet in response to Beet necrotic yellow vein virus. Physiological and Molecular Plant Pathology, 72, 62-72.

Lee L., Telford E.B., Batten J.S., Scholtkof K.-B.G., Rush C.M. (2001) Complete nucleotide sequence and genome organization of Beet soilborne mosaic virus, a proposed member of the genus Benyvirus. Archives of Virology, 146, 2443-2453.

Lee L.Y., Fang M.J., Kuang L.Y., Gelvin S.B. (2008) Vectors for multi-color bimolecular fluorescence complementation to investigate protein-protein interactions in living plant cells. Plant Methods, 4, 24.

Legrain P., Selig L. (2000) Genome-wide protein interaction maps using twohybrid systems. FEBS Letters, 480, 32-36.

Lein J.C., Asbach K., Tian Y., Schulte D., Li C., Koch G., Jung C., Cai D. (2007) Resistance gene analogues are clustered on chromosome 3 of sugar beet and cosegregate with QTL for rhizomania resistance. Genome, 50, 61-71.

Lennefors B.-L., Lindsten K., Koenig R. (2000) First record of A and B type Beet necrotic yellow vein virus in sugar beets in Sweden. . European Journal of Plant Pathology, 106, 199-201.

Letschert J.P.W., Lange W., Frese L., Van Den Berg R.G. (1994) Taxonomy of Beta section Beta. Journal of Sugar Beet Research, 31, 69-85.

Li X.B., Fan X.P., Wang X.L., Cai L., Yang W.C. (2005) The cotton ACTIN1 gene is functionally expressed in fibers and participates in fiber elongation. Plant Cell, 17, 859-875.

Link D., Schmidlin L., Schirmer A., Klein E., Erhardt M., Geldreich A., Lemaire O., Gilmer D. (2005) Functional characterization of the Beet necrotic yellow vein virus RNA-5-encoded p26 protein: evidence for structural pathogenicity determinants. Journal of General Virology, 86, 2115-2125.

Liu H., Reavy B., Swanson M., MacFarlane S. A. (2002) Functional replacement of the tobacco rattle virus cysteinerich protein by pathogenicity proteins from unrelated plant viruses. Virology, 298, 232-239.

Liu H.-Y., Sears J.L., Lewellen R.T. (2005) Occurrence of resistance-breaking Beet necrotic yellow vein virus of sugar beet. Plant Disease, 89, 464-468.

Liu H.-Y., Lewellen R.T. (2007) Distribution and molecular characterisation of resistancebreaking isolates of Beet necrotic yellow vein virus in the United States. Pant Disease, 91, 847-851. 
Luo J., Shen G., Yan J., He C., Zhang H.(2006) AtCHIP functions as an E3 ubiquitin ligase of protein phosphatase 2A subunits and alters plant response to abscisic acid treatment. Plant Journal, 46, 649-657.

Martin G.B., Bogdanove A.J., Sessa G. (2003) Understanding the functions of plant disease resistance proteins. Annual Reviews of Plant Biology, 54, 2361.

Mas P., Kim W.Y., Somers D.E., Kay S.A. (2003) Targeted degradation of TOC1 by ZTL modulates circadian function in Arabidopsis thaliana. Nature, 426, 567-570.

Mayer G., Launhardt H., Munder T. (1999) Application of the green fluorescent protein as a reporter for Ace1-based, two-hybrid studies. Biotechniques, 1, 86-88.

McDowell J.M., Woffenden B.J. (2003) Plant disease resistance genes: recent insights and potential applications. Trends in Biotechnology, 21, 178-183.

McGinnis K.M., Thomas S.G., Soule J.D., Strader L.C., Zale J.M., Sun T.P., Steber C.M. (2003) The Arabidopsis SLEEPY1 gene encodes a putative Fbox subunit of an SCF E3 ubiquitin ligase. Plant Cell, 15, 1120-1130.

Merkouropoulos G., Shirat A.H. (2003) The unusual Arabidopsis extensin gene atEXt1 is expressed throughout plant development and is induced by a variety of biotic and abiotix stresses. Planta, 3217, 356-366.

Miernyk J.A., Thelen J.J. (2008) Biochemical approaches for discovering proteinprotein interactions. Plant Journal, 53, 597-609.

Miyanishi M., Kusume T., Saito M., Tamada T. (1999) Evidence for three groups of sequence variants of beet necrotic yellow vein virus RNA 5. Archives of Virology, 144, 879-892.

Moissard G., Voinnet O. (2004) Viral suppression of RNA silencing in plant. Molecular Plant Pathology, 5, 71-82.

Mouhanna A.M., Langen G., Schlösser E. (2008) Weeds as alternative hosts for BSBV, BNYVV, and the vector Polymyxa betae (German isolates). Journal of Plant Diseases and Protection, 115, 193-198.

Nielsen S.L., Nicolaisen M., Scheel C., Dinesen I.G. (2001) First record of beet necrotic yellow vein virus in Denmark. Plant Disease, 85, 559.

Ohad N., Shichrur K., Yalovsky S. (2007) The analysis of protein-protein interactions in plants by bimolecular fluorescence complementation. Plant Physiology, 145, 1090-1099.

Oltmann W., Burba M., Bolz G. (1984) Fortschritte der Pflanzenzüchtung Vol. 12 edn.: Verlag Paul Parey. 
Paape M., Solovyev A.G., Erokhina T.N., Minina E.A., Schepetilnikov M.V., Lesemann D.E., Schiemann J., Morozov S.Y., Kellmann J.W. (2006) At$4 / 1$, an interactor of the Tomato spotted wilt virus movement protein, belongs to a new family of plant proteins capable of directed intra- and intercellular trafficking. Molecular Plant Microbe Interactions, 19, 874-883.

Pazhouhandeh M., Dieterle M., Marrocco K., Lechner E., Berry B., Brault V., Hemmer O., Kretsch T., Richards K.E., Genschik P., Ziegler-Graff V. (2006) F-box-like domain in the polerovirus protein $P 0$ is required for silencing suppressor function. Proceedings of the National Academy of Sciences USA, 103, 1994-1999.

Pérez-Gómez J., Moore I. (2007) Plant endocytosis: it is clathrin after all. Current Biology, 17, 217-219.

Pfeffer S., Dunoyer P., Heim F., Richards K.E., Jonard G., Ziegler-Graff V. (2002) PO of beet Western yellows virus is a suppressor of posttranscriptional gene silencing. Journal of Virology, 76, 6815-6824.

Pferdmenges F., Korf H., Varrelmann M. (2008) Identification of rhizomaniainfected soil in Europe able to overcome $R z 1$ resistance in sugar beet and comparison with other resistance-breaking soils from different geographic European Journal of Plant Pathology, 10.1007/s10658-008-9388-9

Pferdmenges F., Varrelmann M. (2008) Breaking of Beet necrotic yellow vein virus resistance in sugar beet is independent of virus and vector inoculum densities. European Journal of Plant Pathology, 10.1007/s10658-008-94089

Piroux N., Saunders K., Page A., Stanley J. (2007) Geminivirus pathogenicity protein C4 interacts with Arabidopsis thaliana shaggy-related protein kinase AtSKn, a component of the brassinosteroid signalling pathway. Virology, 362, 428-440.

Ploubidou A., Way M. (2001) Viral transport and the cytoskeleton. Current Opinion in Cell Biology, 13, 97-105.

PoehIman J.M. ed (1986) Breeding field crops 3rd edn.: Van Nostrand Reinhold, New York.

Pompe-Novak M., Wrischer M., Ravnikar M. (2001) Ultrastructure of chloroplasts in leaves of potato plants infected by potato virus YNTN. Phyton-Annales Rei Botanicae, 41, 215-226.

Potuschak T., Lechner E., Parmentier Y., Yanagisawa S., Grava S., Koncz C., Genschik P. (2003) EIN3-dependent regulation of plant ethylene hormone signaling by two Arabidopsis F box proteins: EBF1 and EBF2. Cell, 115, 679-689. 
Putz C. (1977) Composition and structure of Beet necrotic yellow vein virus. Journal of General Virology, 35, 397-401

Qu F., Ren T., Morris T.J. (2003) The coat protein of turnip crinkle virus suppresses posttranscriptional gene silencing at an early initiation step. Journal of Virology, 77, 511-522.

Rahim M.D., Andika I.A., Han C., Kondo H., Tamada T. (2007) RNA4-encoded p31 of beet necrotic yellow vein virus is involved in efficient vector transmission, symptom severity and silencing suppression in roots. Journal of General Virology, 88, 1611-1619.

Ren T., Qu F., Morris T.J. (2000) HRT gene function requires interaction between a NAC protein and viral capsid protein to confer resistance to turnip crinkle virus. Plant Cell, 12, 1917-1926.

Richard-Molard M. (1985) Beet rhizomania disease-the problem in Europe. Report of the 1984 British Crop Protection Conference-Pests and Diseases, 837-845.

Richard-Molard M.S., Cariolle M. (2001) Stress hydrique et abiotique et amélioration genetique. Proc. IIRB 64th Cong. Bruges, Belgium, 153-158.

Ringli C. (2005) The role of extracellular LRR-extensin (LRX) proteins in cell wall formation Plant Biosystems, 139, 32-35.

Ritter E., Debener T., Barone A., Salamini F., Gebhardt C. (1991) RFLP mapping on potato chromosomes of two genes controlling extreme resistance to potato virus X (PVX). Molecular and General Genetics, 227, 81-85.

Ruffel S., Dussault M.H., Palloix A., Moury B., Bendahmane A., Robaglia C., Caranta C. (2002) A natural recessive resistance gene against potato virus $\mathrm{Y}$ in pepper corresponds to the eukaryotic initiation factor 4E (elF4E). Plant Journal, 32, 1067-1075.

Rush C.M. (2003) Ecology and epidemiology of benyviruses and plasmodiophorid vectors. Annual Reviews of Phytopathology, 41, 567-592.

Rush C.M., Liu H.-Y., Lewellen R.T., Acosta-Leal R. (2006) The continuing saga of Rhizomania of sugar beets in the United States. Plant Disease, 90, 4-15.

Saito M., Kiguchi T., Kusume T., Tamada T. (1996) Complete nucleotide sequence of the Japanese isolate $S$ of Beet necrotic yellow vein virus RNA and comparison with European isolates. Archives of Virology, 141, 21632175. 
Schirmer A., Link D., Cognat V., Moury B., Beuve M., Meunier A., Bragard C., Gilmer D., Lemaire O. (2005) Phylogenetic analysis of isolates of Beet necrotic yellow vein virus collected worldwide. Journal of General Viroogyl, 86, 2897-2911.

Schmidlin L., de Bruyne E., Weyens G., Lefebvre M., Gilmer D. (2008) Identification of differentially expressed root genes upon rhizomania disease. Molecular Plant Pathology, 9, 741-751.

Scholten O.E., de Bock T.S.M., Klein-Lankhorst R.M., Lange W. (1999) Inheritance of resistance to Beet necrotic yellow vein virus in Beta vulgaris, conferred by a second gene for resistance. Theoretical and Applied Genetics, 99, 740-746.

Seldmayer K. (1964) Monogerme Zuckerrüben ihre Genetik, Züchtung und Bedeutung für den Zuckerrübenanbau. Züchter, 34, 45-51.

Serebriiskii I.G., Toby G.G., Golemis E.A. (2000) Two-hybrid system for characterization of protein-protein interactions in E.coli. Biotechniques, 29, 288-296.

Silhavy D., Burgyan J (2004) Effects and side-efftsof viral RNA silencing suppressors on short RNAs. Trends in Plant Sciences, 9, 76-83.

Smith D.B., Johnson K.S. (1988) Single-Step Purification of Polypeptides Expressed in Escherichia-Coli as Fusions with Glutathione S-Transferase. Gene, 67, 31-40.

Soellick T., Uhrig J.F., Bucher G.L., Kellmann J.W., Schreier P.H. (2000) The movement protein NSm of tomato spotted wilt tospovirus (TSWV): RNA binding, interaction with the TSWV $\mathrm{N}$ protein, and identification of interacting plant proteins. Proceedings of the National Academy of Sciences USA, 97, 2373-2378.

Sohi H., Maleki M. (2004) Evidence for presence of types A and B of Beet necrotic yellow vein virus (BNYVV) in Iran. Virus Genes, 29, 353-358.

Somers D.E., Kim W.Y., Geng R. (2004) The F-box protein ZEITLUPE confers dosage-dependent control on the circadian clock, photomorphogenesis, and flowering time. Plant Cell, 16, 769-782.

Soosaar J.L.M., Burch-Smith T.M, Dinesh-Kumar S.P. (2005) Mechanisms of plant resistance to viruses. Nature reviews, 3, 789-798.

Spicher J. (2008) Zuckerrübenanbau 2007 in Norddeutschland. Zuckerrübe, 1, 34-36.

Staiger C.J., Blanchoin L. (2006) Actin dynamics: old friends with new stories. Current Opinions in Plant Biology, 9, 554-562. 
Suter B., Kittanakom S., Stagljar I. (2008) Two-hybrid technologies in proteomics research. Current Opinions in Biotechnology, 19, 316-323.

Takemoto D., Doke N., Kawakita K. (2001) Characterization of elicitor-inducible tobacco genes isolated by differential hybridization. Journal of General Plant Pathology, 67, 89-96.

Tamada T. (1999) Benyvirus. In Encyclopedia of Virology. Edited by A. Granoff and R. Webster. Academic Press, New York., pp. 154-160.

Tamada T. (2007) Susceptibility and resistance of Beta vulgaris subsp. maritima to foliar rub-inoculation with Beet necrotic yellow vein virus. Journal of General Plant Pathology, 73, 76-80.

Tamada T., Baba T. (1973) Beet necrotic yellow vein virus from Rhizomaniaaffected sugar beet in Japan. Ann. Phytopath. Soc. Japan 39, 325-332.

Tamada T., Schmitt C., Saito M., Guilley H., Richards K. (1996) High resolution analysis of the readthrough domain of Beet necrotic yellow vein virus readthrough protein: a KTER motif is important for efficient transmission of the virus by Polymyxa betae. Journal of General Virology, 77, 1359-1367.

Tamada T., Uchino H., Kusume T., Saito M. (1999) RNA 3 Deletion Mutants of Beet Necrotic Yellow Vein Virus Do Not Cause Rhizomania Disease in Sugar Beets. Phytopathology, 89, 1000-1006.

Tamada T.S., Abe H., Saito M., Kiguchi T.; Harada T. (1989) Production and pathogenicity of isolates of Beet necrotic yellow vein virus with different numbers of RNA components. Journal of General Virology, 70, 3399-3409.

Uetz P., Hughes R.E. (2000) Systematic and large-scale two-hybrid screens. Current Opinions in Microbiology, 3, 303-308.

van Criekinge W., Beyaert R. (1999) Yeast Two-Hybrid: State of the Art. Biological Procedures Online, 2, 1-38.

van den Burg H.A., Tsitsigiannis D.I., Rowland O., Lo J., Rallapalli G., Maclean D., Takken F.L., Jones J.D. (2008) The F-box protein ACRE189/ACIF1 regulates cell death and defense responses activated during pathogen recognition in tobacco and tomato. Plant Cell, 20, 697-719.

van der Biezen E.A., Jones J.D.G. (1998) Plant disease-resistance proteins and the gene-for-gene concept. Trends in Biochemical Sciences, 12, 454-456.

Varrelmann M. (2007) Vorkommen, Ausbreitung und Pathogenität verschiedener Formen des Rizomaniavirus (Beet necrotic yellow vein virus, BNYVV) Übersichtsbeitrag zur Biologie und Variabilität von Rizomania und zum Nachweis von möglicherweise auftretenden resistenzüberwindenen Isolaten. Zuckerindustrie, 132, 113-120. 
Varshavsky A. (1997) The ubiquitin system. Trends in Biochemical Sciences, 10, 383-387.

Vasavada H.A., Ganguly S., Germino F.J., Wang Z.X., Weissmann S.M. (1991) A contingent replication assay for the detection of protein-protein interactions in animal cells. Proceedings of the National Academy of Sciences USA, 88, 10686-10690.

Vetter G., Hily J.M., Klein E., Schmidlin L., Haas M., Merkle T., Gilmer D. (2004) Nucleo-cytoplasmic shuttling of the beet necrotic yellow vein virus RNA-3-encoded p25 protein. Journal of General Virology, 85, 2459-2469.

Vitale A. (2002) Physical methods. Plant Molecular Biology, 50, 825-836.

Voinnet O. (2005) Inductian and suppression of RNA silencing: insights from viral infections. Nature Reviews Genetics, 6, 206-220.

Voinnet O., Pinto Y. M., Baulcombe D. C. (1999) Suppression of gene silencing: a general strategy used by diverse DNA and RNA viruses of plants. Proceedings of the National Academy of Sciences USA 96, 14147-14152.

von Bargen S., Salchert K., Paape M., Piechulla B., Kellmann J.-W. (2001) Interactions between the tomato spotted wilt virus movement protein and plant proteins showing homologies to myosin, kinesin and DnaJ-like chaperones. Plant Physiology and Biochemistry, 39, 1083-1093.

von Mering C., Krause R., Snel B., Cornell M., Oliver S.G., Fields S., Bork P. (2002) Comparative assessment of large-scale data sets of protein-protein intreactions. Nature, 417, 399-403.

Wallrabe H., Periasamy A. (2005) Imaging protein molecules using FRET and FLIM microscopy. Current Opinions in Biotechnology, 16, 19-27.

Walter, M., Chaba, C., Schutze K., Batistic O., Weckermann K., Nake C., Blazevic D., Grefen C., Schumacher K., Oecking C., Harter K., Kudla J. (2004) Visualization of protein interactions in living plant cells using bimolecular fluorescence complementation. Plant Journal, 40, 428-438.

Wei T., Chen H., Ichiki-Uehara T.,Hibino H., Omura T. (2007) Entry of rice dwarf virus into cultured cells of its insect Vector involves clathrin-mediated endocytosis. Journal of Virology, 81, 7811-7815.

Williamson V.M., Kumar A. (2006) Nematode resistance in plants:the battle underground. Trends in Genetics, 22, 396-403.

Wirtschaftliche Vereinigung Zucker (2008) Zuckermarkt - Anbau und Erzeugung. www.zuckerwirtschaft.de

Xia Y., Lu L.J., Gerstein M. (2006) Integrated Prediction of the Helical Membrane Protein Interactome in Yeast. Journal of Molecular Biology, 357, 339-349. 
Yang C.-W., González-Lamonthe R., Ewan R.A., Rowland O., Yoshioka H., Shenton M., Ye H., O’Donnell E., Jones J.D.G., Sadanandom A. (2006) The E3 Ubiquitin ligase activity of Arabidopsis PLANT U-BOX17 and its functional tobacco homolog ACRE276 are required for cell death and defense. Plant Cell, 18, 1084-1098.

Zhang B., Kraemer B., Sengupta D., Fields S., Wickens M. (2000) Yeast threehybrid system to detect and analyze RNA-protein interactions. Methods Enzymology, 318, 399-419.

Zhou F., Wu G., Deng W., Pu Y., Wei Y., Li Y. (2007) Interaction of rice dwarf virus outer capsid P8 protein with rice glycolate oxidase mediates relocalization of P8. FEBS Letters, 581 34-40.

Zhu S., Gao F., Cao X., Chen M., Ye G. , Wei C., Li Y. (2005) The Rice Dwarf Virus P2 Protein Interacts with ent-Kaurene Oxidases in Vivo, Leading to Reduced Biosynthesis of Gibberellins and Rice Dwarf Symptoms. Plant Physiology, 139, 1935-1945. 


\section{Anhang}

\subsection{Construction of a random primed normalized CDNA library from Beta vulgaris}

\section{Material supplied}

Total RNA from Beta maritima delivered on dry ice.

\section{Analysis of RNA}

Prior to cDNA synthesis the total RNA was analyzed for its integrity by spectrophotometry and denaturing agarose gel electrophoresis (see Fig. 1).

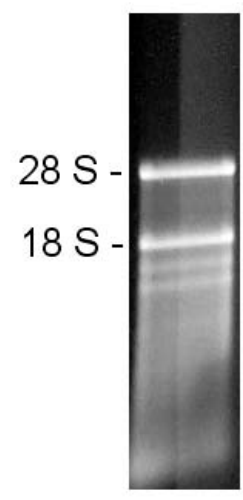

Figure 1: Analysis of total RNA from Beta maritima $(2 \mu \mathrm{g})$ on a 1,2\% denaturing agarose gel.

cDNA synthesis

The cDNA was synthesized according to our standard random priming protocol starting from poly A+ RNA purified from total RNA. With the poly A+ RNA firststrand cDNA synthesis was performed using a random-Xhol-linker primer and $\mathrm{M}$ MLV-RNase $\mathrm{H}$ reverse transcriptase. Synthesis of the second strand was carried out with a second random linker primer and Klenow DNA-polymerase. The resulting N0-cDNA was then amplified with 14 cycles of LAPCR (Barnes 1994, PNAS 91:2216-2220) (see Fig. 2, lane N0) 
Normalization

Normalization was achieved by one cycle of denaturation and reassoziation of the amplified N0-cDNA, resulting in N1-cDNA. Reassoziated ds-cDNA was separated from the remaining ss-cDNA (normalized cDNA) by passing the mixture over a hydroxylapatit column. After hydroxylapatit chromatography, the N1 ss-cDNA was amplified with 13 LA-PCR cycles (see Fig. 2, lane N1).

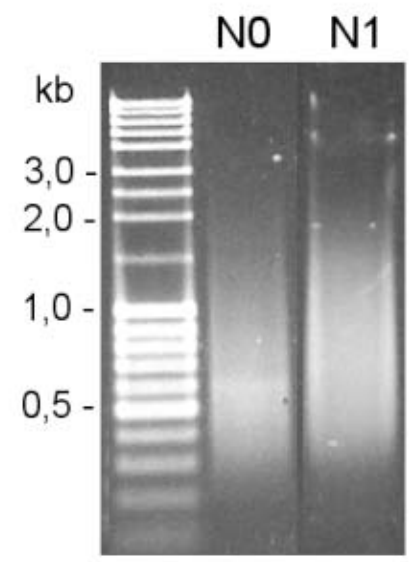

Figure 2: Agarose gel electrophoresis (1,3\% agarose) of the N0- and N1-cDNA from Beta maritima (100 ng each).

Cloning and library amplification

For directional cloning, the N1 cDNA was first subjected to a limited exonuclease treatment to generate Eco RI overhangs at the 5'-ends and was then digested with Xhol.

Prior to cloning, the N1 cDNA was size-fractionated. For that purpose, the cDNA was separated on a 1,3\% agarose gel. Following elution of cDNAs greater than $0,4 \mathrm{~kb}$ the cDNA was ligated into Eco RI and Xho I sites of the plasmid vector pJG4-5.

The following adapter sequences remain attached to the CDNA ends:

5'-end (EcoRl-site) 5'-GAATTCCATCAGGCAGAGGACGAGACAGAACGCA-3' 3'-end (Xho l-site) none 
The cDNA inserts can be released from the vector by an Eco RI / Xho I digestion.

Ligations were electroporated into T1 Phage resistant TransforMax ${ }^{\mathrm{TM}} \mathrm{EC} 100^{\mathrm{TM}}$ (Epicentre) electro-competent cells. After transformation, glycerol was added to a final concentration of $16 \%(\mathrm{v} / \mathrm{v})$ and the cells were frozen at $-70^{\circ} \mathrm{C}$. After a freezethaw cycle, the titer of the library was determined. In total, a number of 1.400 .000 recombinant clones was achieved.

For library amplification $500 \mathrm{ml}$ of ampicillin-containing LB-medium was inoculated with the normalized primary library and plasmid-containing cells were grown to an OD600 of 0,5 . Prior to freezing at $-70^{\circ} \mathrm{C}$ glycerol was added to a final concentration of $16 \%$. After a freeze-thaw cycle, the titer was determined to be about $15.000 \mathrm{cfu} / \mu \mathrm{l}$. The amplified library is delivered in 16 aliquots of $45 \mathrm{ml}$ and 4 aliquots of $1 \mathrm{ml}$

Quality control Gene-specific PCR analysis

To analyze the quality of the N0- and N1-cDNA and the success of the normalization process we performed gene-specific PCR using the customerprovided primer pairs $\mathrm{PA}-1 / \mathrm{Pa}-2$ and $\mathrm{OH} 15$ sense/OH15rev3 that generate a 925 bp fragment of the Bvpal-cDNA and a 374 bp fragment of the Beta-specific transcription factor cDNA.

The PCR-products obtained from 10 ng N0- and N1-cDNA after 28 (Bvpal-cDNA) and 26 (Beta-specific transcription factor) cycles under the conditions recommended by the customer were checked by agarose gel electrophoresis (see Fig. 3). The results of the gene specific PCR analysis suggest higher expression of the Beta-specific transcription factor mRNA in comparison to that of the Bvpal mRNA. Accordingly, the relative abundance of the transcription factor is decreased in the normalized cDNA while that of Bvpal-cDNA remains unchanged. 


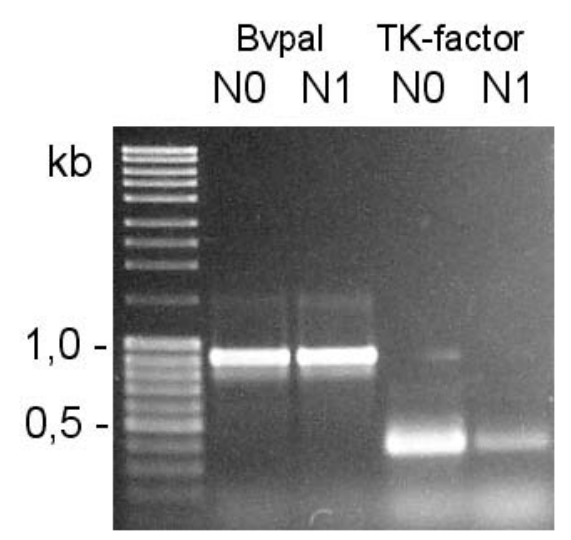

Figure 3: Relative abundance of a $925 \mathrm{bp}$ Bvpal fragment and a $374 \mathrm{bp}$ fragment of the Beta-specific transcription factor in the N0- and N1-cDNA from Beta maritima as obtained after 28 and 26 PCR cycles from equal amounts (10 ng) of cDNA.

Colony PCR analysis of the primary N1-cDNA library and determination of mean insert size. With 48 randomly chosen clones of the primary cDNA library colony PCR analysis was performed. PCR reactions were carried in with the $5^{\prime}-P C R$ primer used for cDNA amplification and a primer binding 40 bp downstream from the $X$ ho I site in the vector. Therefore, together with the insert, $40 \mathrm{bp}$ of the vector DNA are co-amplified.

PCR products were analyzed after 30 cycles on a 1,3\% agarose gel (Fig. 4).

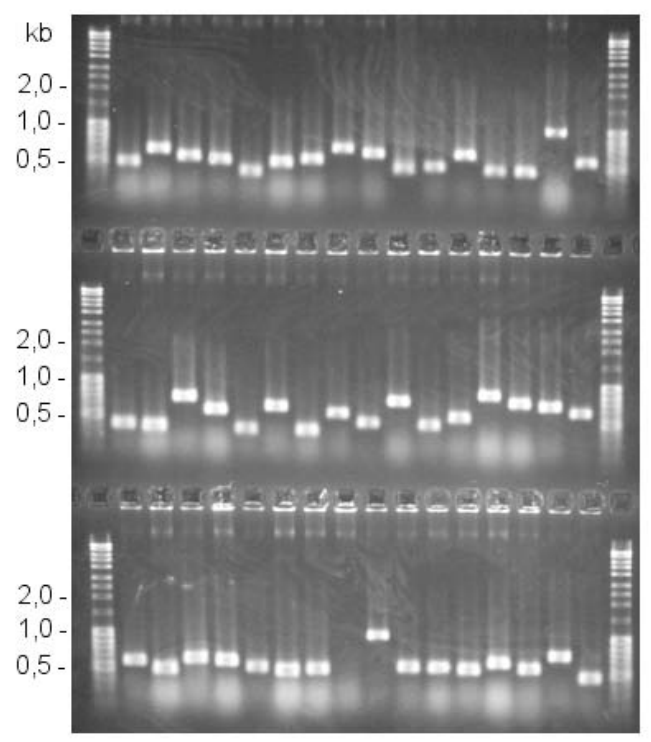

Figure 4: Colony PCR analysis. PCR products were run on a 1,3\% agarose gel. 
Table 2: Statistical evaluation of colony PCR

\begin{tabular}{|l|c|c|}
\hline Insert size & Number & Percent \\
\hline$>1000 \mathrm{bp}$ & 2 & 4 \\
\hline $400-1000 \mathrm{bp}$ & 45 & 94 \\
\hline$<400 \mathrm{bp}$ & 0 & 0 \\
\hline without insert & 1 & 2 \\
\hline
\end{tabular}

Mean insert size of the 48 clones analyzed: $600 \mathrm{bp}$ 


\section{Danksagung}

Ich möchte mich ganz besonders bei Herrn Prof. Dr. Mark Varrelmann für die Überlassung des interessanten Themas, die stete Diskussions- und Hilfsbereitschaft, sowie für die Unterstützung bei der Anfertigung dieser Arbeit bedanken.

Bei Prof. Dr. Heiko Becker möchte ich mich für die Übernahme des Korreferats bedanken.

Mein Dank gilt auch der Gemeinschaft zur Förderung der privaten Pflanzenzüchtung (GFP) und der Arbeitsgemeinschaft industrieller Forschungsvereinigungen e.V. (AiF), die mich finanziell in dieser Arbeit unterstützt haben.

Ein besonderes Dankeschön möchte ich den ehemaligen Mitarbeitern der Arbeitsgruppe Pflanzenvirologie des Departments für Nutzpflanzenwissenschaften aussprechen, denn ohne sie wären die molekularen Arbeiten im Labor für mich um einiges schwieriger gewesen.

Des Weiteren möchte ich mich bei den Zuckerrübenzüchterhäusern KWS SAAT AG, Strube-Dieckmann und Sygenta Seeds $A B$ für die hilfreichen Sequenzierungs- und Kartierungsarbeiten meiner Kandidaten bedanken.

Besonderer Dank gebührt meiner Laborkollegin, Mitdoktorandin und der im Rahmen dieser Arbeit neu gewonnen guten Freundschaft mit Elke Nitschke, vor allem für ihre Diskussionsbereitschaft, das Korrekturlesen meiner Dissertation und den vielen gemeinsamen Erkundigungen in Göttingen.

Von ganzem Herzen möchte ich Grit Haseneyer für ihre Geduld, ihre Unterstützung, das offene Ohr zu jeder Zeit sowie für das Korrekturlesen dieser Arbeit und den immerwährenden Glauben an mich, danken. 
Allen Mitarbeitern des Fachgebietes Pflanzenschutz und Pflanzenpathologie möchte ich besonders für die letzten Monate am IPP danken, denn ohne Euch wäre es zum Schluß nur halb so schön gewesen. Bei Nadine Riediger und Christina Eynck möchte ich mich vor allem für die vielen lustigen Stunden und gemeinsamen Aktivitäten bedanken.

Mein tiefer Dank gilt meinen Eltern, die immer für mich immer da sind und mir stets mit Rat und Tat zur Seite standen. 


\section{Verzeichnis der Publikationen und Tagungsbeiträge}

\section{Publikationen:}

Draghici, H.K.D., Pilot, R., Thiel, H. \& Varrelmann, M. (2008) Functional mapping of PVX RNA-dependent RNA-replicase using pentapeptide scanning mutagenesis - identification of regions essential for replication and subgenomic RNA amplification. Virus Research, in press.

Peltier, C., Hleibieh, K. Thiel, H., Klein, E., Bragard, C. \& Gilmer, D. (2008) Molecular Biology of the Beet necrotic yellow vein virus. Plant Viruses, 2, 14-24.

Thiel H., Hleibieh, K., Gilmer, D. \& Varrelmann M. (2009) Beet necrotic yellow vein virus P25 pathogenicity factor interacts with a sugar beet F-box protein from resistant and susceptible genotypes involved in the induction of a hypersensitive resistance response. submitted to Journal of Virology,

Thiel, H. \& Varrelmann, M. (2009) Identification of beet necrotic yellow vein virus P25 pathogenicity factor interacting sugar beet proteins which represent putative virus targets or components of plant resistance.

Molecular Plant Microbe Interactions, in press.

\section{Poster und Präsentationen:}

Thiel, H. \& Varrelmann, M. (2006) Etablierung eines YTH-Systems zur Charakterisierung der Interaktion zwischen beet necrotic yellow vein virus (BNYVV) Pathogenitätsfaktor P25 und einer $R z 2+R z 3$ resistenten Zuckerrübe auf Proteinebene. DPG-Arbeitskreis "Pflanzenvirologie", 29-31.03.2006 Freudenstadt, Deutschland. 
Thiel, H. \& Varrelmann, M. (2006) Fishing for sugar beet proteins interacting with BNYVV RNA3 encoded P25 pathogenicity factor IIRB Study group on "Pests and Diseases", 24.-26.05.2006 - Sevilla, Spanien.

Thiel, H. \& Varrelmann, M. (2006) Etablierung eines "Yeast two-hybrid Systems" zur Charakterisierung der Interaktion zwischen beet necrotic yellow vein virus (BNYVV) und $R z 2+R z 3$ resistenten Zuckerrübe auf Proteinebene. 55. Deutsche Pflanzenschutztagung. 25. - 28. 092006 - Göttingen, Deutschland.

Thiel, H. \& Varrelmann, M. (2007) "Yeast two hybrid" Identifizierung und Charakterisierung von Interaktionen des Pathogenitätfaktors P25 des beet necrotic yellow vein virus (BNYVV) mit Kandidaten einer cDNA -Bibliothek des Rübengenoms. DPG - Arbeitskreis „Pflanzenvirologie“, 29.-30.03.2007 _ Quedlinburg, Deutschland.

Thiel, H. \& Varrelmann, M. (2008) Sugar beet proteins interacting with RNA-3 encoded pathogenicity factor of Beet necrotic yellow vein virus. 71 st IIRB Congress. 13 - 14.02.2008. Brüssel, Belgien.

Thiel, H. \& Varrelmann, M (2008) Protein-protein interaction screen of a sugar beet cDNA library identifies several proteins physically interacting with the beet necrotic yellow vein virus pathogenicity factor P25. 7. Symposium of the International Working Group on Plant Viruses with Fungal Vectors, 01.-04.09.2008 - Quedlinburg, Deutschland.

Thiel, H. \& Varrelmann, M. (2009) The P25 pathogenicity factor of Beet necrotic yellow vein virus physically interacts with several sugar beet proteins possibly involved in virus pathogenicity or plant resistance. 35th General Meeting of the ASSBT, 25-28.02.2009 - Orlando, USA.

Thiel, H. \& Varrelmann, M. (2009) Applying P25 pathogenicity factor of beet necrotic yellow vein virus in yeast two-hybrid interaction hunt on the Rz2 sugar beet proteome identifies several candidate proteins possibly involved in virus 
pathogenicity or plant resistance. Advances in Plant Virology - Harrogate International Centre, 01.-03.04.2009 - Harrogate, England.

Thiel, H. \& Varrelmann, M. (2009) Protein-protein interaction screen of a sugar beet cDNA library with the beet necrotic yellow vein virus pathogenicity factor P25 identifies proteins possibly involved in virus pathogenicity and plant resistance response. 5th Joint meeting of Dutch and German Plant Virologists, 08.09.04.2009 - Hamburg, Deutschland. 


\section{Lebenslauf}

\section{Persönliche Daten:}

Name:

Geburtsdatum:

\section{Schulausbildung:}

1983 - 1987

$1987-1989$

$1989-1996$

\section{Berufsausbildung :}

1996 - 1998

\section{Anstellungen:}

09/2004 - 09/2008

seit $10 / 2008$

\section{Studium:}

1998 - 2003

$10 / 1998-10 / 2000$

$10 / 2000$

$11 / 2000-10 / 2002$

$11 / 2002-10 / 2003$
Heike Thiel

23.07.1976 in Gehrden

Grundschule Bordenau

Orientierungsstufe Süd, Neustadt a. Rbge

Gymnasium Neustadt a. Rbge.

Abschluss: Abitur

Ausbildung zur Gärtnerin, Fachrichtung Zierpflanzenbau

Gärtnerei Ehlers-Ernst GmbH, Wunstorf/Steinh.

Abschluss: Gärtnerin

Studium der Gartenbauwissenschaften an der Universität Hannover Abschluss: Diplom- Agraringenieurin Grundstudium

Vordiplom

Hauptstudium

Diplomarbeit:

Untersuchungen zur Mikrosporenkultur bei Arabidopsis thaliana im Vergleich zu Brassica napus

Wissenschaftliche Mitarbeiterin an der Universität Göttingen,

Department für Nutzpflanzenwissenschaften, AG Pflanzenvirologie

Wissenschaftliche Mitarbeiterin am Institut für Zuckerrübenforschung (IfZ), Göttingen 


\section{E r k I ärungen}

1. Hiermit erkläre ich, daß diese Arbeit weder in gleicher noch in ähnlicher Form bereits anderen Prüfungsbehörden vorgelegen hat.

Weiter erkläre ich, daß ich mich an keiner anderen Hochschule um einen Doktorgrad beworben habe.

Göttingen, den

2. Hierrmit erkläre ich eidesstattlich, daß diese Dissertation selbständig und ohne unerlaubte Hilfe angefertigt wurde.

Göttingen, den 